\title{
Listen, lusten en lasten van massamediale voorlichting : de planning van publieksgerichte interventies
}

Citation for published version (APA):

Damoiseaux, V. M. G. (1991). Listen, lusten en lasten van massamediale voorlichting : de planning van publieksgerichte interventies. [Doctoral Thesis, Maastricht University]. Rijksuniversiteit Limburg. https://doi.org/10.26481/dis.19910328vd

Document status and date:

Published: 01/01/1991

DOI:

10.26481/dis.19910328vd

Document Version:

Publisher's PDF, also known as Version of record

Please check the document version of this publication:

- A submitted manuscript is the version of the article upon submission and before peer-review. There can be important differences between the submitted version and the official published version of record.

People interested in the research are advised to contact the author for the final version of the publication, or visit the DOI to the publisher's website.

- The final author version and the galley proof are versions of the publication after peer review.

- The final published version features the final layout of the paper including the volume, issue and page numbers.

Link to publication

\footnotetext{
General rights rights.

- You may freely distribute the URL identifying the publication in the public portal. please follow below link for the End User Agreement:

www.umlib.nl/taverne-license

Take down policy

If you believe that this document breaches copyright please contact us at:

repository@maastrichtuniversity.nl

providing details and we will investigate your claim.
}

Copyright and moral rights for the publications made accessible in the public portal are retained by the authors and/or other copyright owners and it is a condition of accessing publications that users recognise and abide by the legal requirements associated with these

- Users may download and print one copy of any publication from the public portal for the purpose of private study or research.

- You may not further distribute the material or use it for any profit-making activity or commercial gain

If the publication is distributed under the terms of Article $25 \mathrm{fa}$ of the Dutch Copyright Act, indicated by the "Taverne" license above, 
Listen, lusten en lasten van massamediale voorlichting 



\section{LISTEN, LUSTEN EN LASTEN VAN MASSAMEDIALE VOORLICHTING}

De planning van publieksgerichte interventies.

$$
\text { proefschrift }
$$

ter verkrijging van de graad van doctor aan de Rijksuniversiteit Limburg te Maastricht, op gezag van de Rector Magnificus, Prof. Mr. M.J. Cohen, volgens het besluit van het College van Dekanen, in het openbaar te verdedigen op donderdag, 28 maart 1991 om 14.00 uur in de aula van de universiteit.

door

Victor Marie Guillaume Damoiseaux geboren te Amby in 1949 
Promotoren:

Prof. dr. G.J. Kok

Prof. dr. C. M. J. van Woerkum, L.U. Wageningen

Beoordelingscommissie:

Prof. dr. P.G. Knipschild (voorzitter)

Prof. dr. H. Philipsen

Prof. dr. J.G. Stappers, KU. Nijmegen

Prof. dr. J. Vinck, L.U.C. Hasselt (B.)

Dr. F. Nijhuis

Lay-out: Ger Houben, Maastricht

Omslag ontwerp: Rien Bekkers, Amsterdam

Trefwoorden: voorlichting, massamedia, campagnes, sociale psychologie

Alle rechten voorbehouden

Copyright 1991

Logistic support: D.W.W., Postbus 380, 6200 A] Maastricht 
Inhoudsopgave

Inleiding

Hoofdstuk 1 Het conceptuele kader

$1.1 \quad$ Inleiding

1.2 Definitie van voorlichting

1.3 Grondvormen van voorlichting

1.4 Voorlichting als beleidsinstrument

1.5 De complexiteit van voorlichting

1.6 Slotbeschouwing

Hoofdstuk 2 Gezondheidswoorlichting als modaliteit van intentionele voorlichting

2.1 Inleiding

$2.2 \quad$ GVO als funktie van preventie

23 GVO als vorm van intentionele voorlichting

24 De systematiek van intentionele voorlichting

2.5 De doelgerichtheid van intentionele voorlichting

2.6 De planmatigheid van intentionele voorlichting

27 Slotbeschouwing

Hoofdstuk 3 Motivatie als angrijpingspunt voor verandering

3.1 Inleiding

3.2 Nadere begripsbepaling

3.3 Motivatie; determinanten van gedrag

$\begin{array}{lll}3.4 & \text { Categorisering van gedragsdeterminanten } & 61\end{array}$

3.5 Van instincten via driften naar cognities $\quad 62$

3.6 Cognitieve motivatietheoriee̊n 64

3.7 Cognitieve consistentietheorieën 66

3.8 De ontwikkeling van fundamentele behoeften tot concrete motieven 68

3.9 Slotbeschouwing 
Hoofdstuk 4 Het verwerven van informatie

4.1 Inleiding 75

4.2 De ontvanger als uitgangspunt $\quad 76$

4.3 Uses and gratifications $\quad 81$

4.4 De instrumentele bruikbaarheid van informatie 84

4.5 Het referentiemodel van het planmatig zoekproces 88

4.6 De sense-making approach 90

4.7 Slotbeschouwing 93

Hoofdstuk 5 Modellen van intentionele voorlichting

5.1 Inleiding 97

5.2 Het informatieprocesmodel 98

5.3 De theoretische fundering van de "communication/persuasionmatrix" 102

5.4 Het model van gedragsverandering door voorlichting 118

5.5 Het Elaboration-Likelyhoodmodel 122

5.6 Het integratiemodel 126

5.7 De relatie attitude - gedrag 132

5.8 Slotbeschouwing 135

Hoofdstuk 6 Het pretesten van voorlichtingsmateriaal

$\begin{array}{lll}6.1 & \text { Inleiding } & 139\end{array}$

6.2 Noodzaak van pretesten 141

6.3 Voorwaarden voor pretesten $\quad 142$

6.4 Voordelen van pretesten 144

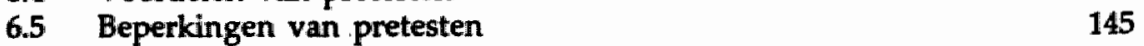

6.6 Inhoud van de pretest 147

$\begin{array}{ll}\text { 6.7 De testroute } & 149\end{array}$

6.8 Methoden van pretesten 152

6.9 Slotbeschouwing 164

Hoofdstuk 7 De effecten van massamediale voorlichting

$\begin{array}{lll}7.1 & \text { Inleiding } & 165\end{array}$

$\begin{array}{lll}7.2 & \text { Nadere begripsbepaling van effectiviteit } & 167\end{array}$

$\begin{array}{ll}7.3 & \text { Beoogde versus niet beoogde effecten } \\ 768\end{array}$

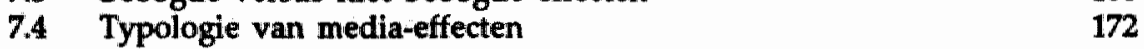

$\begin{array}{ll}7.5 & \text { Directe versus indirecte effecten } \\ 776\end{array}$

$\begin{array}{ll}7.6 & \text { Effecten van massamediale campagnes } \\ 7 & 182\end{array}$

$\begin{array}{lll}7.7 & \text { Nederlandse voorlichtingscampagnes } & 187\end{array}$

$\begin{array}{ll}7.8 & \text { Slotbeschouwing } \\ & 196\end{array}$ 
Hoofdstuk 8 Preventie van skiblessures, een gerandomiseerde interventiestudie

8.1 Inleiding

8.2 De doelstelling van de interventie

8.3 Probleemanalyse en gedragsdeterminantenanalyse

8.4 Concretisering van hetinterventiedoel

8.5. De compositie van de boodschap

8.6 Methode van onderzoek 221

8.7 Resultaten 226

8.8 De effecten van de voorlichting 235

8.9 Discussie en conclusies 246

Hoofdstuk 9 Patientenvoorlichting via de massamedia

9.1 Inleiding

9.2 Probleemstelling 253

9.3 Methoden 254

9.4 Resultaten 255

9.4.1 De opinie van huisartsen over massamediale voorlichting 257

9.4.2 De mening van het publiek over massamediale voorlichting 257

9.4.3 De voorkeur voor informatieve programma's 260

$\begin{array}{lll}9.5 & \text { Slotbeschouwing } & 261\end{array}$

\section{Hoofdstuk 10 Epiloog}

10.1 Inleiding

10.2 Samenvatting

10.3 Aanbevelingen 273

10.4 Listen, lusten en lasten 280

Summary

Literatuur

Curriculum vitae 



\section{Inleiding}

De komst van steeds meer nieuwe media en de gestage groei van de micro-electronica draagt ertoe bij dat in wetenschappelijke kring nog steeds wordt nagedacht en onderzocht wat de feitelijke invloed van de massamedia is op het publiek.

Middelerwijl is men het er over eens dat de omnipotentie van de media danig aan het tanen is. Het is meer uitzondering dan regel wanneer de media de gemoederen explosief in beroering brengen. Onderschatten moeten we de kracht van de media ook weer niet. Zo wordt bijvoorbeeld telkenmale verwezen naar de gigantische bedragen die de commercie spendeert aan reclame-uitingen en nog steeds worden ongewenste ontwikkelingen (bijvoorbeeld de kleine criminaliteit) toegeschreven aan de almacht van de media. Het paradoxale schuilt in het adagium "ergens wel en ergens niet en alles wat daar tussen zit". Dit boek is bestemd voor diegenen, die geloof hechten aan "ergens wel", namelijk zij die de massamedia willen benutten voor verwezenlijking van bepaalde sociale doelstellingen.

Dit boek is geen Delfisch naslagwerk, het bevat geen receptuur en biedt geen instant-oplossingen voor de (massa)communicatieproblematiek. Vanuit een sociaal-psychologische invalshoek wordt een aantal aspecten behandeld die relevant zijn voor de planning en evaluatie van massamediale voorlichtingsinterventies. Uit recente buitenlandse literatuur blijkt steeds opnieuw dat de effectiviteit van massamediale voorlichting voor een belangrijk deel bepaald wordt door de kwaliteit van de planning. Kennelijk is dit gegeven nog onvoldoende doorgedrongen tot de Nederlandse voorlichters want de planning en 
evaluatie van voorlichtingscampagnes die georganiseerd worden om gezondheid, welzijn en veiligheid te bevorderen, laten nog veel te wensen over. Dit boek probeert deze complexe materie inzichtelijker te maken.

Dit werk vangt aan op de klassieke wijze: eerst wordt de gehanteerde terminologie verduidelijkt en wordt het begrippenapparaat toegelicht. Ten aanzien van voorlichting worden twee grondvormen onderscheiden, namelijk faciliterende en intentionele voorlichting. De intentionele voorlichting vormt de kern van dit werk: de voorlichter wil welbewust bepaalde veranderingen in kennis, attitude en gedrag bewerkstelligen bij het publiek of delen daarvan. De complexiteit van deze vorm van voorlichting wordt geillustreerd door aandacht te schenken aan voorlichting als beleidsinstrument. Het is schering en inslag dat voorlichting via massamedia wordt geproclameerd omdat andere beleidsinstrumenten ontoereikend zijn om bepaalde problemen tot een goede oplossing te brengen. Voorlichting via de massamedia is echter geen panacee!

Voor het optimaal benutten van deze technische hulpmiddelen is het noodzakelijk dat men systematisch, doelgericht en planmatig te werk gaat. Deze fundamenten van intentionele voorlichting worden nader beschreven in het tweede hoofdstuk waarin tevens aandacht wordt geschonken aan gezondheidsvoorlichting als modaliteit van preventie.

Een essentieel uitgangspunt van voorlichting is dat de opzettelijke beïnvloedingspogingen via informatie-overdracht berusten op vrijwillige verandering. Dit impliceert niet alleen dat dwang in de vorm van wet en regelgeving taboe is maar veeleer dat de kracht van de voorlichting moet schuilen in het motiveren tot ander gedrag. Motivatie wordt door voorlichters vaak opgevat als de sleutel tot verandering; immers motivatie verwijst naar een drijvende kracht achter het menselijk handelen, de dynamiek die mensen er toe aanzet bepaalde dingen te doen of na te laten. In hoofdstuk 3 wordt gepoogd om de conceptuele verwarring over motivatie op te helderen en het begrip voor de toepassing van voorlichting toegankelijk en geschikt te maken. Vervolgens richten we onze aandacht in hoofdstuk 4 op hoe mensen met informatie omgaan. In dit hoofdstuk wordt een pleidooi gehouden om zich meer te verdiepen in de positie en situatie van de ontvanger. De voorlichter dient in de huid van de ontvanger te kruipen vooraleer hij plannnen gaat ontwikkelen voor bewuste verandering. Gewezen wordt op het belang van contextuele variabelen ten aanzien van het gebruik van informatie. In hoofdstuk 5 laten 
we een aantal recente modellen de revue passeren, die aangewend kunnen worden bij de strategische planning van een massamediale interventie. Aan de hand van de denkbeelden van McGuire wordt een aantal condities opgesomd, die aangemerkt kunnen worden als minimale eisen voor voorlichting als instrument van (gedrags)verandering. Ook wordt erop gewezen dat gedragsverandering via attitudeverandering niet zaligmakend behoeft te zijn.

In de loop van dit werk benadrukken we steeds opnieuw dat uiterste zorgvuldigheid moet worden betracht bij het samenstellen van de boodschap. In hoofdstuk 6 breken we dan ook een lans voor het pretesten van de voorlichtingsmaterialen. Het is genoegzaam bekend dat voorlichtingsboodschappen vaak niet goed begrepen worden en niet aankomen bij die mensen waarvoor ze bedoeld zijn. Als aan deze primaire eisen niet wordt voldaan, zijn verdere pogingen te beschouwen als boter aan de galg. Om te vermijden dat boodschappen niet conform de intentie van de voorlichter overkomen, alsmede om ongewenste neveneffecten te voorkomen, wordt uitvoerig ingegaan op de vraag welk traject men dient te volgen om tot een verantwoord voorlichtingsprodukt te komen. Ook wordt daarbij een overzicht gegeven van pretestmethoden.

Het theoretisch gedeelte wordt afgesloten met een hoofdstuk over de effecten van massamediale voorlichtingscampagnes. De effecten worden vanuit verschillende invalshoeken belicht. Bijgevoegd is een beknopte evaluatie van Nederlandse campagnes. We komen tot de slotsom dat campagne-activiteiten in Nederland slechts magere resultaten laten zien.

In het tweede gedeelte van dit boek wordt verslag gedaan van een gerandomiseerde interventie-studie ter preventie van skiblessures. In deze studie worden een drietal experimentele condities gehanteerd om te achterhalen welke educatieve interventie-methode het meest geschikt is om ski-blessures te voorkomen. In dit onderzoek is gepoogd om de ideeën, opvattingen en bevindingen die vervat zijn in het theoretisch gedeelte te integreren. In hoofdstuk 10 willen we laten zien dat er over de invloed van de televisie nog veel misverstand bestaat. Het werk wordt beëindigd met een aantal aanbevelingen voor de praktijk van de voorlichting.

Beek/Maastricht, zomer 1990.

Vic. Damoiseaux. 



\title{
Hoofdstuk 1 Het conceptuele kader
}

\author{
1.1 Inleiding \\ 1.2 Definitie van voorlichting \\ 1.3 Grondvormen van voorlichting \\ 1.4 Voorlichting als beleidsinstrument \\ 1.5 De complexiteit van voorlichting \\ 1.6 Slotbeschouwing
}

\section{$1.1 \quad$ Inleiding}

Wie serieus op zoek gaat naar een definitie van "voorlichting" kan een keuze maken uit een ruim assortiment. Naar believen kan men kiezen uit pragmatische, doelgerichte of normatieve definities. De een is wat specifieker, de ander wat concreter en een derde is vollediger. De meeste auteurs hanteren een definitie als een paraplu. In deze betekenis gaat het om een definitie van een begrip als deelverzameling, door vastlegging van alle elementen of alle deelverzamelingen die er onder vallen. Door definiëring tracht men de connotatieve betekenis van een begrip of theoretisch construct te verwoorden door het geven van synoniemen, door betekenisvergelijking of door het begrip te vervangen door operationele termen. Bij wijze van inleiding stellen ze de lezers op de hoogte vanuit welke optiek en met welk doel zij een begrip gebruiken. In vele gevallen wordt daarbij tevens aangegeven wat wel en wat niet tot een bepaald domein gerekend wordt. 
De Groot en Medendorp (1986) stellen dat een definitie het wezen van de zaak moet weergeven. De gedachte dat een definitie behoort te zeggen wat een ding is, en wel min of meer definitief en compleet, blijkt de schrijver dezes well degelijk parten te spelen. Zonder afbreuk te willen doen aan auteurs die in het verleden behartenswaardige formuleringen hebben genoteerd, is het bij nadere beschouwing niet mogelijk om voor een algemeen aanvaarde definitie te kiezen die past in de optiek van dit manuscript. Weliswaar is getracht om op basis van vergelijking van de gangbare definities (Van den Ban, 1985; Röling, 1988; Van Woerkum, 1987; Van Gent, 1990; Katus, 1980; Wapenaar et al., 1988) tot een distillaat te komen, maar deze poging is gestrand op het gegeven dat voornoemde auteurs zich bedienen van verschillende soorten definities.

Indien we ons zouden laten leiden door de gedachten van De Groot en Medendorp (1986), die de definitie zien als het (definitief) eindresultaat van een studie, dan zou het voor de hand liggen om de definitie aan het eind van een boek - waarin men tot de kern van de zaak is doorgedrongen - te plaatsen en niet als een noodzakelijk begin om het eigenlijke onderzoek of betoog mee te starten. Een dergelijke benadering, waarop wetenschappelijk niets valt af te dingen, zou dit werk uit zijn band doen springen! Er zijn echter ook wetenschapstheoretici die genoegen nemen met definities indien men er in slaagt om het object nauwkeurig te identificeren. Wij achten het van belang vooraf - op basis van een kritische beschouwing van de literatuur - aan te geven wat de connotatieve en denotatieve betekenissen zijn van de belangrijkste begrippen, die in dit manuscript gehanteerd worden.

\subsection{Definitie van voorlichting}

Alle vormen van voorlichting hebben gemeen dat er informatie dienstbaar gemaakt wordt voor een (sub)populatie zodat een bijdrage geleverd kan worden aan het oplossen van individuele en maatschappelijke problemen. Het instrument om informatie dienstbaar te maken is communicatie. Informatie wordt communicatief door toedoen van een zender. Een zender kan dit instrument op verschillende manieren hanteren en op verschillende wijzen aanwenden om bepaalde informatie middels een boodschap over te brengen naar de ontvangers. Communicatie heeft dus betrekking op het overdragen van informatie 
waarbij vier basiselementen (bron, boodschap, kanaal, ontvanger) met elkaar verstrengeld zijn, dat wil zeggen een bepaalde configuratie hebben, waardoor ze betekenis krijgen. Transmissie van informatie op zichzelf is onvoldoende om te kunnen spreken van communicatie; ook de relaties tussen de basiselementen moeten in beschouwing genomen worden. In het bovenstaande hebben we communicatie aangeduid als "instrument" ${ }^{\prime \prime}$ zonder daarbij een sluitende definitie te geven. Dit zou communicatiewetenschappers weleens in het verkeerde keelgat kunnen schieten. Vandaar dat wij er onmiddellijk aan toevoegen dat we communicatie beschouwen als middel ter beïnvloeding. Het begrip "communicatie" is in kringen van wetenschapsbeoefenaren een hoogst intrigerend en complex verschijnsel. Dit in tegenstelling tot het dagelijks taalgebruik waar kennelijk nauwelijks spraakwerwarring bestaat over deze term; iedereen weet ongeveer wel wat er onder begrepen moet worden. Communicatiewetenschappers hanteren in de regel de volgende criteria om communicatie te beschrijven c.q. af te bakenen: a. intentionaliteit, b. geslaagdheid, c. reciprociteit.

Bij intentionaliteit gaat het om de vraag of de zender de uitdrukkelijke bedoeling heeft om iets te communiceren. Of dit al dan niet gebeurt met een opzettelijke doelstelling, in de zin van gewenste effecten, laten we even buiten beschouwing. Bij geslaagdheid als criterium gaat het om de verwezenlijking van een bepaalde doelstelling, die verschillende gradaties kan aannemen, bijvoorbeeld aanhoren, lezen, reageren. Met reciprociteit wordt bedoeld dat in de informatiestroom sprake moet zijn van tweerichtingsverkeer. Anders geformuleerd: de participanten vervullen beurtelings de rol van zender en ontvanger. Uit een breed arsenaal van definities hebben we gekozen voor de omschrijving van Hovland (1948): "The process by which an individual (the communicator) transmits stimuli (usually verbal symbols) to modify the behavior of other individuals (communicatees)". De essentie van Hovland's definitie is het beïnvloeden met een middel. In deze betekenis sluit deze (ruime) omschrijving het best aan bij onze opvattingen over voorlichting. Voor ons betoog is niet alleen "communicatie" maar ook "communicatief gedrag" interessant. Stappers (1990) haalt in dit verband Fearing aan en stelt: "Het gaat bij communicatief gedrag om vier gebieden van studie:

1. De krachten die de effecten van communicatie bepalen; hierbij gaat het om personen die door Fearing als "interpreters" worden aangeduid. 
2. De krachten die de productie van boodschappen bepalen, hier gaat het on communicatoren.

3. De aard van de boodschap ("communication content"), te zien als een stimulus-veld.

4. De kenmerken van situatie of veld waarin de communicatie plaatsvindt.

De onderdelen hebben interdependente relaties met elkaar: wat er gebeurt in die verschillende gebieden is "dynamically interrelated"; dat houdt onder andere in dat wat in het ene gebied gebeurt, gevolgen heeft in andere gebieden. (Stappers et al., 1990, pag. 172).

Stappers (1986) stelt dat het bij communicatie gaat om "kennisverwerking uit de tweede hand", waarmee hij bedoelt dat communicatie betrekking heeft op het indirect verwerven van kenniseenheden van iemand anders. Dit behoeft geenszins te betekenen dat het uitsluitend om directe waarneming of beleving gaat; evenzo kan het betrekking hebben op het doorgeven van elders opgedane ervaringen of het uitwisselen van gevoelens of ideeën.

Informatie is een aaneenschakeling van signalen en symbolen, die op zichzelf betekenisloos zijn maar die door toedoen van de ontvanger een bepaalde inhoud krijgen. Stappers (1966) gebruikt de term informatie wanneer de boodschap bij de ontvanger leidt tot kennen, iets aan de weet komen. Deze opvatting ligt ook opgesloten in de diverse informatietheorieën, namelijk het reduceren van onzekerheid. Ook Van Woerkum (1982) verstaat onder informatie al datgene dat tot kennis kan leiden, maar brengt ten aanzien van voorlichting de restrictie aan dat de informatie empirisch verifieerbaar is.

In het voorafgaande hebben we gesteld dat voorlichting in wezen betrekking heeft op het dienstbaar maken van informatie voor een gro(o)t(er) publiek. In het woord dienstbaar ligt dan meteen de doelstelling van de voorlichting opgesloten, namelijk dat mensen de aangeboden informatie kunnen verwerken en toepasbaar kunnen maken voor hun eigen doen en laten. Dit impliceert niet alleen dat de informatie gemakkelijk toegankelijk en op maat gesneden moet worden voor de ontvanger, maar ook dat het samenstellen van de boodschap gebonden is aan bepaalde kwaliteitseisen om de beoogde doelstellingen te bewerkstelligen. Een voorlichter dient dus te beschikken over bepaalde competenties (vaardigheden zowel als kennis en inzicht) om de ontvanger die informatie aan te reiken die hem in de 
gelegenheid stelt om zijn eigen problemen op te lossen, te verhelderen en te verkennen. $\mathrm{Nu}$ is problemen oplossen wellicht een wat zwaar woord. Wij hanteren het hier als verzamelterm zowel voor hulp bij menings- en besluitvorming (Van den Ban, 1985) als voor verbreding van het blikweld en het doorbreken van denkbarrières (Wiedenhof, 1988). Wij willen de term voorlichting niet slechts reserveren voor problematiek op individueel niveau. Voorlichting kan ook tot doel hebben om collectieve, maatschappelijke problemen op te lossen. Het begrip dienstbaar hebben we gekozen omdat dit woord zeer geschikt is om daar tal van activiteiten onder te brengen die als doelstelling van de transmissie van informatie kunnen gelden: raadgeven, toelichten, adviseren, verklaren, verhelderen, bevorderen, kennis verhogen, etc. We rekenen daartoe ook bewustmaken, beïnvloeden en veranderen. We komen hier nog uitgebreid op terug (zie hoofdstuk 7).

Resumerend kunnen we stellen dat een voorlichter iemand is die het instrument communicatie doelgericht hanteert om informatie dienstbaar te maken voor een breder publiek. Voorlichting is kort en bondig "knowledge utilisation", kennisbenutting. Inherent aan deze brede definitie van voorlichting is de consequentie dat aanverwante informatie-overdracht ook met het predikaat voorlichting kan worden verrijkt. We denken hierbij aan reclame, public relations, propaganda, etc. Weliswaar zijn dit modaliteiten van communicatie omdat ze zich ook bedienen van informatieverstrekking, maar de doelstellingen dienen niet primair de belangen van de ontvanger of het collectief belang. Zo dient bijvoorbeeld de informatieverschaffing met betrekking tot public relations ter bescherming van de goede naam van de opdrachtgever. Het zal duidelijk zijn dat het hierbij meer gaat om graduele dan om principiële verschillen. Tegelijkertijd moeten we er aan toevoegen dat in de beroepsbeoefening sprake is van een zekere mate van syncretisme, dat wil zeggen dat de verschillende modaliteiten met elkaar verstrengeld zijn waardoor een wezenlijke scheiding tussen de verschillende modaliteiten vervaagt. $\mathrm{Zo}$ zal bijvoorbeeld in een nationale campagne ter beteugeling van het drankmisbruik de voorlichter aangewezen zijn op de medewerking van een journalist en anderzijds kan de journalist gebruik maken van de diensten van de voorlichter. 


\subsection{Grondwormen wan voorlichting}

In het voorafgaande hebben we voorlichting ruim gedefinieerd, namelijk informatie dienstbaar maken aan een breed publiek teneinde daarmee een bijdrage te leveren aan de oplossing van een individueel en/of maatschappelijk probleem. Alle vormen van voorlichting hebben gemeen dat ze het belang van de ontvanger dienen.

Voorlichting is per definitie doelgericht; informatieverstrekking zonder doel is zinloos. In de literatuur (Wapenaar et al., 1989) wordt de doelgerichtheid nogal eens vervat in de term "interventie", waarmee wordt bedoeld dat de voorlichter opzettelijk een communicatieve activiteit in gang zet om een bepaalde doelstelling te realiseren. Vanuit de optiek van de voorlichter kunnen we twee grondvormen van voorlichting onderscheiden, namelijk intentionele voorlichting en faciliterende voorlichting.

Bij faciliterende voorlichting is het de bedoeling van de zender om de ontvanger vrijblijvend kennis te laten nemen van "objectieve" informatie. Deze voorlichting laat de ontvanger vrij om naar eigen goeddunken de informatie te consumeren. Deze voorlichting is te beschouwen als dienstverlening of informatieservice en heeft een toelichtend, verklarend of verhelderend karakter. Te denken valt bijvoorbeeld aan een folder waarin tekst en uitleg gegeven wordt over een bepaalde voorziening, aan een gebruiksaanwijzing bij een electrisch apparaat of aan een telefonisch informatiecentrum waar men terecht kan met vragen over het invullen van een belastingformulier.

Bij intentionele voorlichting streeft de zender er bewust naar om veranderingen bij de ontvanger aan te brengen in cognities, attitudes en gedrag. In vergelijking met faciliterende voorlichting heeft deze vorm van voorlichting een "dwingend" karakter. Haastig moet er aan toegevoegd worden dat voorlichting als instrument van sociale verandering berust op vrijwilligheid, dat wil zeggen dat de ontvanger zèlf bepaalt of hij zich aan de informatie blootstelt en hoe hij deze verwerkt. Het woord "dwingend" moet dan ook opgevat worden in de zin van sturend. Bij voorlichting zijn immers geen sancties in het geding. Ligt bij faciliterende voorlichting de nadruk op incidentele kennisoverdracht, bij intentionele voorlichting ligt het accent meer op het stabiliseren van kennis gericht op houdings- en gedragsverandering. Bij faciliterende voorlichting wordt doorgaans gebruik gemaakt van én medium terwijl bij intentionele voorlichting in de regel 
multimediaal te werk wordt gegaan. De faciliterende voorlichting komt tegemoet aan de manifeste behoefte aan informatie bij de ontvanger. $\mathrm{Bij}$ intentionele voorlichting daarentegen gaat het zowel om een manifeste als een latente behoefte. Bij intentionele voorlichting kan men bijvoorbeeld als doelstelling formuleren: het zich bewustworden van een bepaald probleem. In tegenstelling tot de faciliterende voorlichting wordt het probleem bij intentionele voorlichting niet door de ontvanger onderkend, maar door de voorlichter of voorlichtende instantie gesignaleerd. Schematisch kunnen we de verschillen tussen intentionele en faciliterende voorlichting als volgt weergeven:

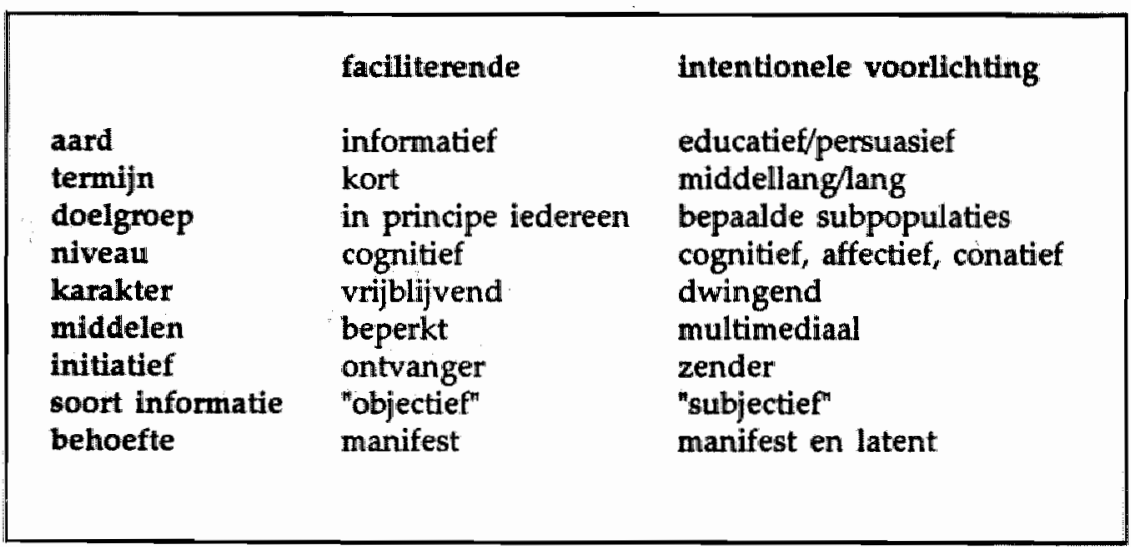

Figuur 1.1 Verschillen tussen intentionele en faciliterende voorlichting.

Een enkele kanttekening bij deze verschillen is gewenst met name wat betreft de aspecten termijn, middelen en soort informatie. Bij het aspect termijn staat aangegeven dat faciliterende voorlichting zich afspeelt op de korte termijn en dat bij intentionele voorlichting sprake is van midden/lange termijn. Dit is voor kritiek vatbaar in die zin dat het wel denkbaar is dat intentionele voorlichting zich op korte termijn afspeelt, bijvoorbeeld in het geval van smogalarm. Ook is het mogelijk dat faciliterende voorlichting zich over een ruimere tijd uitstrekt, bijvoorbeeld een folder over de aanvraag van huursubsidie. De term termijn wekt misverstand in de hand als men daarbij niet vermeldt 
dat daarmee bedoeld wordt dat dit doorgaans betrekking heeft op het formuleren van doelstellingen en het realiseren van effecten. Eenzelfde redenering geldt voor de frequentie. Het is goed voorstelbaar dat intentionele voorlichting wel degelijk een incidenteel, dat wil zeggen een tijdelijk karakter heeft (bijvoorbeeld een wak in het ijs). Bij faciliterende voorlichting wordt in beperkte mate gebruik gemaakt van de verschillende hulpmiddelen. Men kiest doorgaans voor een combinatie van twee massamedia bijvoorbeeld een televisie-spot in combinatie met een folder. Intentionele voorlichting wordt gekenschetst door een multimediale aanpak met dwarsverbindingen naar interpersonale voorlichting. Bij faciliterende voorlichting is het streven gericht op het verstrekken van objectieve informatie. Dat is een nobel streven. Of "objectiviteit" inderdaad haalbaar is, laten we hier even buiten beschouwing. Bij intentionele voorlichting heeft de informatie een duidelijke functie om te overreden. Dit impliceert bijvoorbeeld een doordacht gebruik van argumenten, een weloverwogen keuze voor eenzijdige versus tweezijdige berichtgeving, de voorkeur voor een emotionele versus rationele benadering, etc.

De keuze voor intentionele of faciliterende voorlichting is niet louter een kwestie van voorkeur van de voorlichter. Deze is sterk afhankelijk van de doelstelling die men wil verwezenlijken, maar bovenal van de complexiteit van het probleem dat men wil oplossen. Op de tweede plaats is de keuze afhankelijk van de gekozen doelpopulatie en de media die men ter beschikking heeft. Het zal duidelijk zijn dat bij opzettelijke pogingen tot beïnvloeding van kennis, attitude en gedrag meer rekening gehouden moet worden met sociaal-psychologische processen, die een begunstigende dan wel een belemmerende invloed kunnen uitoefenen op het uiteindelijke resultaat. Bovendien is het van essentieel belang de kosten/baten af te wegen en rekening te houden met een aantal ethische complicaties (waarheid, betrouwbaarheid, onbaatzuchtigheid) die bij beïnvloeding van gedrag de nodige aandacht opeisen. In het navolgende zullen we de problematiek van overheidsvoorlichting bespreken omdat daarin de verhouding tussen faciliterende en intentionele voorlichting duidelijk geprofileerd wordt. 


\subsection{Voorlichting als beleidsinstrument}

De in de vorige paragraaf onderscheiden vormen van voorlichting vinden we terug bij hogere en lagere overheden, die voorlichting verschaffen aan de burgers.

Nederland kent het democratische recht op openbaarheid waarin de vrijheid van informatie is vastgelegd. In de uit 1978 daterende wet Openbaarheid van Bestuur (WOB) zijn geregeld de passieve openbaarheidsplicht (verzoek om informatie over overheidsdocumenten) en de plicht tot voorlichting op eigen initiatief, de zogenaamd actieve openbaarheidsplicht.

Riley (1987) formuleert het openbaarheidsbeginsel als een grondrecht: de vrijheid van meningsuiting als equivalent van de vrijheid van informatie stelt de burger in staat om de handel en wandel van de verschillende overheidsorganen kritisch te volgen en te controleren. De Meij (1987) stelt dat er ten onzent nog geen sprake is van een openbaarheidsplicht. Zowel in de huidige wet als in de nieuwe wetsvoorstellen wordt gesproken over een verzoek om informatie en niet over het recht op informatie. Volgens De Meij blijkt uit parlementaire stukken dat de overheid als voornaamste doelstelling van de openbaarheidswet "het vergroten van de betrokkenheid van het publiek bij de openbare zaak" hanteert. De burger zou meer moeten participeren in het doen en laten van de overheid, zo lijkt de onderliggende gedachte. "Als de mensen beter kunnen volgen wat er gebeurt, dan wordt het beleid ook gemakkelijker geaccepteerd", zo stelt De Meij en merkt daarbij op: "Van de vergroting van de controlemogelijkheden ten aanzien van het doen en laten van de overheid wordt nauwelijks gerept." Volgens De Meij is het dan ook beter om te spreken van een voorlichtingswet dan van een openbaarheidswet. Naast voorlichting op verzoek heeft de overheid de plicht om uit eigener beweging het publiek van informatie te voorzien. Daartoe beschikt zij over een drietal mogelijkheden: persvoorlichting, voorlichting via intermediaire kaders en categorale voorlichtingsinstanties en publieksvoorlichting. Met name de publieksvoorlichting heeft de laatste tijd veel stof doen opwaaien; de discussie concentreert zich op twee vragen, te weten wat de effectiviteit is van de overheidsvoorlichting en de vraag of de overheidsvoorlichting afdwaalt naar overheidspropaganda. Met dit laatste wordt gedoeld op het al dan niet geoorloofd zijn van het aanwenden van massacommunicatieve middelen ten eigen bate. De overheid wil middels beleid een aantal 
maatschappelijke ontwikkelingen in de door haar gewenste richting sturen om daarmee het functioneren van de maatschappij in goede banen te leiden. Over het gevoerde beleid dient zij aan de volksvertegenwoordiging verantwoording af te leggen. Naast wet- en regelgeving en voorwaardenscheppende activiteiten kan de overheid voorlichting aanwenden als beleidsinstrument. Het beleidsinstrument "voorlichting" theeft een ruimere scoop dan in de WOB is aangegeven. Het gaat niet alleen om het verduidelijken, toelichten en verklaren van het aanvaarde beleid maar maakt als een geintegreerd deel uit van het beleidsinstrumentarium. Voorlichting in het kader van de uitvoering van beleid heeft als oogmerk het beinvloeden van gedrag van mensen in een bepaalde richting en het legitimeren van bepaalde wetten en regelingen (Katus, 1987). Conform de door ons gehanteerde definitie van voorlichting is hier sprake van intentionele voorlichting. Deze kan op gespannen voet staan met de faciliterende voorlichting, waarin het openbaarheidsbeginsel vervat is. In de toelichting bij het ontwerp artikel 8 van de WOB wordt het symbiotisch samengaan van beide vormen van voorlichting geregeld. Publieksbeinvloeding is volgens artikel 8 toegestaan, mits voldaan wordt aan de volgende criteria:

1. het betreft aanvaard beleid;

2. het betreft een in de samenleving niet te controversieel onderwerp;

3. het betreft een voorlichtingsuiting, die inhoudelijk voldoende en juiste gegevens bevat om belanghebbenden en belangstellenden in staat te stellen een zelfstandig oordeel te vormen.

Volgens De Meij (1987) zijn deze criteria juridisch gezien "boterzacht"; de vraag dringt zich dan ook op hoever men mag gaan met het veranderen van houding en gedrag zonder overtreding van democratische spelregels.

Het valt niet te ontkennen dat overheidsvoorlichting, evenals nagenoeg alle vormen van voorlichting, een bewuste of onbewuste poging tot beïnvloeden is. Indien daarbij de belangen van de ontvanger gediend worden, is dit ethisch nog wel te verantwoorden. Het wordt echter een bedenkelijk verschijnsel als voorlichters zich niet bewust zijn van het feit dat zij met hun voorlichting kunnen manipuleren. Van der Meiden (1975) plaatst deze problematiek in het kader van de verantwoordelijkheid van de zender. Hij stelt dat verantwoordelijkheid pas realiseerbaar is als de partners in het proces van informatie van gelijk niveau zijn en op gelijk niveau aanspreekbaar. In de 
(intentionele) voorlichting is dit een netelige kwestie of om in termen van Van der Meiden te spreken: "...bij massacommunicatieve uitingen is dit nooit het geval, omdat de zender de "eerste" is, starter in het proces, filter en selecteur, vormgever van de informatie. De ontvanger is vrijwel steeds passief, kan later reageren, heeft een onvermijdelijke achterstand en mist de technische verspreidingscapaciteit van zijn meningen." Vanwege deze ongelijkwaardigheid koppelt Van der Meiden de verantwoordelijkheid dan ook aan het begrip vrijheid. Hij merkt daarbij op dat de ethisch geladen term vrijheid (vrijheid van meningsuiting, -garing en -distributie) vooral als vrijheid van de zender moet worden opgevat. Voor die vrijheid geldt een keten van verantwoordelijkheden:

a. de verantwoordelijkheid van de journalist (in de brede zin van het woord) tegenover zijn opdrachtgever;

b. idem tegenover het publiek;

c. idem van de mediabeheerder tegenover het publiek;

d. van hen samen tegenover de samenleving die door hen beinvloed wordt;

e. van het publiek zelf, dat zich van zijn macht bewust moet worden tegenover de media. (Van der Meiden, 1975, pag. 5).

Het verwaarlozen van het normatieve besef bij de beïnvloeding van het menselijk gedrag zou niet alleen de geloofwaardigheid van de voorlichter ernstig kunnen schaden, maar zou de overheid in een kwaad daglicht stellen op verdenking van machtsmisbruik. Katus (1987) noemt de problematiek van de beïnvloedende voorlichting een schijnvraagstuk. Indien de overheid er niet in slaagt om middels vrijwillige verandering van gedrag de gewenste doelstellingen te realiseren, zal zij eerder andere beleidsinstrumenten aanwenden dan zich schuldig maken aan manipulatieve overreding. Als voorbeelden brengen wij in herinnering de verplichting tot het dragen van helmen bij bromfietsers en de verplichting tot het dragen van veiligheidsgordels in auto's. Overigens zal het niet zo'n vaart lopen met manipulatieve overreding, omdat in dit land de overheidsvoorlichting moet concurreren op de informatiemarkt. De overheid beschikt vandaag de dag niet over de vereiste condities om de bevolking middels overreding haar wil op te leggen. In dit verband willen we het klassieke artikel uit 1948 van Merton en Lazersfeld memoreren waarin zij aangeven dat "Propaganda for social objectives" bij voorbaat tot mislukken gedoemd is als niet tenminste voldaan wordt aan een van de volgende condities: monopolisatie, kanalisatie en supplementatie. 
Van monopolisatie is sprake wanneer er geen of nauwelijks informatie-overdracht is die tegengestelde informatie, beleid of publieke opinie ten aanzien van het aanvaarden van nieuwe ideeën of veranderingen bevat. Met kanalisatie wordt bedoeld dat de media aansluiting zoeken bij bestaande opvattingen, attitudes en gedragingen en deze te versterken en te bestendigen in de gewenste richting. Supplementatie wordt geconcretiseerd door het aanvullen met en bundelen van diverse media en aansluiting te zoeken bij de bestaande netwerken. Op deze wijze worden het gebruik van media geoptimaliseerd en bekrachtigd door interpersonale communicatie.

Ofschoon men attent moet zijn op de schaduwzijden van de overheidsvoorlichting (en bijgevolg de ongewenste neveneffecten) is het in dit kader belangrijker om stil te staan bij de effectiviteit en efficiëntie van de voorlichting.

Overheidsbeleid in het algemeen en overheidsvoorlichting in het bijzonder moeten volgens Hoogerwerf (1985) voldoen aan tenminste vier maatstaven:

1. doeltreffendheid

2. doelmatigheid

3. legitimiteit

4. redelijke argumentatie.

In vergelijking met andere beleidsinstrumenten (dwang, regelgeving, subsidiëring) is voorlichting een beperkt (machts)middel. Voorlichting is te prefereren boven andere beleidsinstrumenten vanwege de relatief geringe kosten en het feit dat het een publieksvriendelijk middel is. Maar de effectiviteit staat op een laag pitje, zo concludeert Hoogerwerf (1985). Hij baseert deze uitspraak op evaluatie-onderzoek van onder andere de Verstedelijkingsnota en het rapport adviescommissie onderzoek Minderheden, Discriminatie, Vooroordeel en Racisme in Nederland. Twintig jaar geleden signaleerde Dekker (1969) al dat de overheidsvoorlichting weliswaar meegroeit met de kwalitatieve en kwantitatieve toename van de overheidstaken, maar dat ze niet (verder) wordt ontwikkeld. We vermoeden dat deze stelling voor een aantal ministeries heden ten dage nog opgeld doet en daarmee kan een mogelijke verklaring gegeven worden voor het uitblijven van goede resultaten. Een andere reden zou gevonden kunnen worden in het feit dat voorlichting slechts zeer sporadisch als geïntegreerd deel van het beleid is opgenomen (De Leeuw, 1989, pag. 128-129). 
Winsemius (1985) heeft een eerste aanzet gegeven om voorlichting systematisch als instrument van beleid concreet vorm te geven. Winsemius gaat er van uit dat het oplossen van collectieve vraagstukken doorgaans volgens eenzelfde cyclus verloopt, namelijk:

1. het signaleren en onderkennen van een probleem,

2. beleidsformulering - afweging van doelen en middelen,

3. beleidsuitvoering - het oplossen van het vraagstuk,

4. beleidscontrole - de bereikte doelen onder controle houden.

Om een vraagstuk volgens deze cyclus, conform de beleidscriteria van Hoogerwerf, tot een goede oplossing te brengen is het zaak om de juiste combinatie van beleidsinstrumenten aan te wenden. De juiste combinatie (de beleidsmix) heeft betrekking op een zorgvuldige (af)weging van het beschikbare instrumentarium. Inherent aan deze redenering zou dus in iedere fase van de cyclus het voorlichtingsaspect aan de orde moeten worden gesteld. In de eerste fase van de "beleidslevenscyclus van Winsemius" is voor voorlichting een radarfunctie weggelegd, namelijk het opvangen en registreren van wat er gaande is in de samenleving; het systematisch verzamelen van relevante informatie en standpunten van maatschappelijke groeperingen en instituties. Het actief verzamelen van gegevens stelt de beleidsfunctionaris in de gelegenheid om - naast het herkennen van potentiële problemen - vroegtijdig in te grijpen. In de tweede fase, de beleidsformulering, wordt rekening gehouden met de informatie die reeds bij de doelpopulatie aanwezig is en hoe er over mogelijke oplossingen gedacht wordt. In wezen wordt bij het zoeken naar een oplossing reeds geanticipeerd op de verwachtingen, wensen en mogelijkheden van de doelgroep. Het hoeft daarom weinig betoog dat in deze fase van de cyclus de nadruk ligt op doelgroepgerichtheid, waarbij een strategische afweging van alle relevante beleidsinstrumenten plaatsvindt. Winsemius somt een viertal mogelijkheden op om communicatie in de beleidsmix aan te wenden, te weten:

1. Alleen communicatie: intentionele voorlichting moet op eigen kracht een oplossing voor het probleem aandragen. Andere beleidsinstrumenten worden buiten beschouwing gelaten.

2. Communicatie als aanvullend instrument: hierbij wordt gezocht naar een combinatie met een ander beleidsinstrument. Het gaat er dus om dat de beleidsinstrumenten functioneel worden ingezet om gezamenlijk tot een oplossing te geraken. 
3. Communicatie als instrument ter ondersteuning: hierbij wordt faciliterende voorlichting gebruikt om andere beleidsmaatregelen te verhelderen, toe te lichten en te verklaren.

4. Dienstverlenende voorlichting. Deze faciliterende voorlichting vloeit voort uit de WOB en is bedoeld om de burgers in de gelegenheid te stellen gebruik te maken van hun democratische rechten.

Uit oogpunt van doelmatigheid en doeltreffendheid zal een voorlichtings-strategie ontwikkeld moeten worden om de beschikbare methoden en technieken van beinvoeding zo optimaal mogelijk aan te wenden. Het optimaal benutten van methoden en techieken dient gerelateerd te worden aan de inhoud van de boodschap en aan de geformuleerde doelstelling(en).

In de fase van beleidsuitvoering komt de implementatie van de voorlichting aan de orde. In de planning zijn de strategische lijnen uitgezet volgens welke de voorlichting dient te verlopen. In de uitvoering komt het er op aan om vorm te geven aan details, het proces te bewaken en te anticiperen op ontwikkelingen, die een remmende dan wel begunstigende invloed hebben op het proces. Winsemius wijst er op dat in deze fase speciale aandacht geschonken moet worden aan de noodzaak van openheid en controleerbaarheid, de evaluatie en het vóorkomen van over-informatie.

In de vierde fase, de controle-fase, is het zaak om de gerealiseerde doelstellingen te continueren. Winsemius spreekt hier van "communicatie als beheersinstrument"; men dient attent te zijn op signalen die wijzen in de richting van aanpassing en vernieuwing. Met dit laatste wordt in wezen de cyclus opnieuw in gang gezet.

De reden om uitvoerig stil te staan bij de gedachtengang van Winsemius was het onderzoek van Van Harberden en Verklaar (1988) naar de ontwikkelingsgang van overheidsvoorlichting in Nederland. Uit dit onderzoek blijkt dat voorlichting als beleidsinstrument volgens de benadering van Winsemius tot tevredenheid stemt. Van Woerkum (1990) gaat nog een stap verder en stelt dat het beleid mede via voorlichting tot stand komt: "Voorlichting is niet alleen een product van een beleidsproces, als een instrument naast en in combinatie met andere instrumenten, maar ook een onderdeel van dit proces",

Een andere reden is dat de benadering van Winsemius in grote trekken overeenkomt met onze visie op voorlichting, namelijk een activiteit die berust op de trias: planmatigheid, doelgerichtheid en 
systematiek. In hoofdstuk 2 zullen we deze aspecten van intentionele voorlichting uitgebreid aan de orde stellen.

\subsection{De complexiteit van voorlichting}

Te pas en te onpas wordt een beroep gedaan op voorlichters om belangrijke maatschappelijke problemen te lijf te gaan met voorlichting. De roep om voorlichting wordt steeds luider als het gaat om problemen waar bij voorbaat geen efficiënte oplossing voor handen is of om problemen waar andere beleidsmiddelen hebben gefaald. Te denken valt bijvoorbeeld aan het probleem van de zure regen of de bestrijding van druggebruik.

De door ons gehanteerde definitie van voorlichting gaat uit van een normatieve visie: het belang van de ontvanger moet met voorlichting gediend zijn. Mastenbroek (1987) vindt dat de meeste definities nogal altruïstisch aandoen, alsof het louter om het exclusief geëerbiedigde belang van de voorgelichte zou gaan. Relativerend voegt hij daaraan toe: "Niet vergeten mag echter worden, dat achter elke voorlichtingsdaad een beleid staat, met een beleidsdoelstelling en met de belangen van degenen die daaraan hun plaats in de samenleving danken (Mastenbroek, 1987, pag. 100). In het geval van overheidsvoorlichting is het wel denkbaar dat het belang van de overheid, die immers verantwoordelijkheid draagt voor pogingen om de samenleving te sturen, het individuele belang overstijgt. Het belang voor het individu moet niet begrepen worden als persoonlijk voordeel van de individuele ontvanger. Het belang van het individu kan ook gediend zijn als de ontvanger er geen direct persoonlijk profijt van heeft, maar er op termijn wel bij vaart. Als voorbeeld kunnen we de omgang met klein chemisch afval aanhalen. De persoon zal zich eerst moeite moeten getroosten om op een milieuvriendelijke manier om te gaan met dit afval alvorens hij/zij de vruchten kan plukken van een schoner milieu. Met dit voorbeeld stoten we op het dilemma van individueel versus collectief belang waarmee de complexiteit van voorlichting geillustreerd kan worden.

Paisley (1981) beziet voorlichtingscampagnes gericht op het handhaven, beschermen of bevorderen van het collectieve belang als instrument van sociale controle.

Sociale controle kan uitgeoefend worden middels drie strategieën om de maatschappij te ordenen: 
1. de educatieve strategie

2. de engineering strategie

3. wet- en regelgeving.

Bij het oplossen van grote maatschappelijke problemen zal doorgaans een combinatie van de drie strategieên toegepast worden. De meest voor de hand liggende strategie om collectieve problemen op te lossen is engineering: het aanwenden van technologie, het beschikbaar stellen van faciliteiten en het creëren van voorzieningen. Zodra blijkt dat de engineering ontoereikend is, wordt een beroep gedaan op de educatieve strategie. Het voeren van campagnes is een onderdeel van de educatieve strategie. Echter, campagnes kunnen ook opgevat worden als een integraal deel van de engineering-strategie en wet- en regelgeving. Indien de educatieve strategie faalt of de effectiviteit betwist wordt, wordt overgegaan tot wet- en regelgeving. In wezen zijin de hierbovengenoemde strategieën geen echte aiternatieven in de zin dat ze onderling inwisselbaar zijn. De keuze voor een strategie wordt niet alleen bepaald door de aard en omvang van het probleem, maar vooral door de verwachting hoe mensen zullen reageren op de wijze waarop de probleemoplossing ter hand wordt genomen. Indien bijvoorbeeld blijkt dat de educatieve strategie, die uitgaat van vrijwillige aanpassing, niet de gewenste resultaten oplevert, worden er drastischer maatregelen voorgesteld. Van Woerkum (1990) heeft de positionering van voorlichting ten opzichte van andere beleidsinstrumenten onder de loep genomen. In onderstaand schema geeft Van Woerkum de relatie weer tussen voorlichting als vorm van overheidsingrijpen en andere beleidsinstrumenten (dwang, geld, voorzieningen, sociale druk).

Uit dit schema blijkt dat de instrumenten die de overheid kan inzetten, elkaars effect kunnen verzwakken of versterken. Zo kan voorlichting de werking van andere instrumenten ondersteunen (en vice versa), maar ook een deel van de beoogde verandering zelfstandig bewerkstelligen. Kortom, de positie van voorlichting kan zowel bovengeschikt, ondergeschikt en nevengeschikt zijn. In wezen geldt dit in feite voor alle vormen van gedragsverandering en is dit niet specifiek voor de overheid. De overheid is natuurlijk gemakkelijker bij machte om de instrumenten te combineren. Aan de basis van het model van Van Woerkum liggen de processen ten grondslag waarop gedragsverandering tot stand kan komen, namelijk inwilliging, identificatie en internalisatie (Kelman, 1970). 


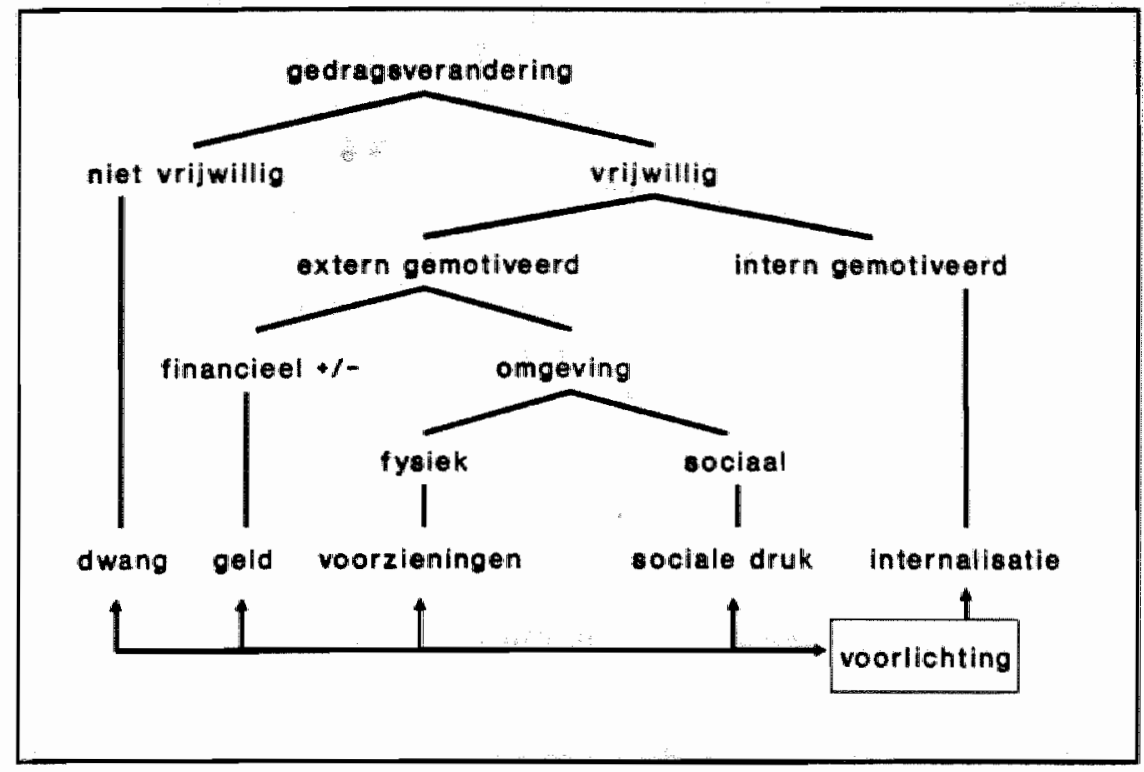

Figuur 1.2 Voorlichting en gedragsverandering.

Bron: Van Woerkum, 1990, pag. 18.

Indien we vanuit de optiek van gezondheidsvoorlichting naar de sociale controle kijken, dan kan men bedenkingen hebben om bijvoorbeeld de preventie van kanker onder sociale controlle te rangschikken. Immers het voork6́men van een dergelijke ziekte lijkt een puur individuele zaak. We moeten hierbij echter bedenken dat massamediale campagnes gericht zijn op grote groepen mensen; een massamediale benadering is dan ook alleen maar gerechtvaardigd indien het probleem zich op grote schaal manifesteert. De preventie van kanker is weliswaar direct een individueel belang maar indirect een collectief belang omdat de gevolgen cq. de kosten worden afgewenteld op de samenleving als totaal.

Binnen de educatieve strategie kunnen twee benaderingen worden onderscheiden, namelijk een reactieve en een proactieve. De reactieve benadering is bedoeld ter oplossing van sociale problemen. De proactieve is gericht op het beinvloeden van beslissingen voordat problemen optreden. Het zal duidelijk zijn dat dit onderscheid verregaande 
consequenties heeft voor de implementatie van de campagne(s). In de regell richt de proactieve benadering zich op heterogene groepen of collectiviteiten, omdat doorgaans nog niet vastgesteld kan worden wie tot de potentièle doelgroep gerekend kan worden, terwijl bij de reactieve benadering de mogelijkheid wel aanwezig is om tot op zekere hoogte segmenten in de doelpopulatie aan te brengen.

De materie wordt complexer wanneer het individuele belang en het collectieve belang conflicteren. Klandermans (1986) spreekt in dit verband van een sociaal dilemma: als individuele belangen prefereren, schaadt dit het collectief belang op de lange termijn. Een collectief doel vergt de gezamenlijke inspanning van zeer velen en kan alleen verwezenlijkt worden, indien mensen zich daadwerkelijk inspanningen getroosten om de verworvenheden van een collectief goed veilig te stellen of het collectief belang te bevorderen.

Er van uitgaande dat we bij voorlichting motivatie(principes) als leidraad hanteren, vormt de beloningsbenadrukking een struikelblok bij publiekscampagnes met een collectief doel. Het problematische schuilt namelijk in het gegeven dat het individu ervan overtuigd moet raken dat zijn bijdrage (in de vorm van de gewenste verandering) essentieel is voor het realiseren van een collectief belang. Hierbij speelt de verwachting omtrent het gedrag van anderen een wezenlijke rol. Individuen getroosten zich geen inspanning als blijkt dat die moeite tevergeefs is door toedoen van anderen. Bij het realiseren van een collectief goed ontbreekt dus niet alleen een persoonlijke gratificatie op korte termijn, maar ook de effectiviteit op de lange termijn wordt in twijfel getrokken. Moeilijkheden doen zich ook voor ten aanzien van de cognitieve ordening. Bij collectieve problemen ervaren mensen meestal niet - ook al worden ze direct aangesproken op hun verantwoordelijkheid ten aanzien van hun eigen doen en laten - dat ze door een indivuduele gedragswijziging een gemeenschappelijk doel dienen. De consequenties van deze problemen manifesteren zich pas op de langere termijn. Collectieve problemen, die geen directe gevolgen hebben voor het dagelijks handelen en waarvan men het idee heeft dat een individu geen wezenlijke bijdrage aan de oplossing daarvan kan leveren, staan niet in het brandpunt van de belangstelling van de persoon. De ontvankelijkheid voor de informatie is niet hoog omdat de informatie het individu niet persoonlijk raakt. In dit verband is de selectiviteitshypothese van Schramm (1961) van toepassing. Schramm stelt dat de selectie van informatie afhankelijk is van de beloning, die de ontvanger van de desbetreffende mediaboodschap 
verwacht en de inspanning, die hij zich moet getroosten om de boodschap te verwerven. Bij het propageren van een collectief belang is het onontbeerlijk om de informatie te relateren aan het eigen belang op zowel de korte als lange termijn (Kok en Siero, 1985). Bovenal moet zij aansluiten bij de eigen opvattingen en interessewereld van de doelpopulatie.

Kok en Siero (1985) hebben onderzocht welke factoren een begunstigende dan wel een bedreigende invloed hebben op het deelnemen aan een actie met een collectief belang. De studie had betrekking op het deelnemen aan een blikrecycling-actie. De onderzoekers hebben getracht de theoretische inzichten van McGuire (1973), Fishbein en Ajzen (1975), Rogers (1983) en Schwarz (1977) als verklaringsmodellen te hanteren voor deelname aan de aktie.

Participatie aan de actie werd onderzocht aan de hand van een model waarin theoretische inzichten vanuit drie invalshoeken zijn geïntegreerd, namelijk: het informatieprocesmodel (McGuire, 1985), de relatie tussen beliefs, attitudes en gedrag (Fishbein en Ajzen, 1975) en de acceptatie van de eigen verantwoordelijkheid (Schwarz, 1977). Het informatieprocesmodel werd in dit onderzoek empirisch ondersteund. Ofschoon de deelnemers een positieve attitude hadden ten aanzien van de deelname aan de actie, resulteerde dit niet in verandering van gedrag. Mensen met een hoog besef van eigen verantwoordelijkheid met betrekking tot milieu doen niet vaker mee aan de actie dan anderen, maar geven wel blijk van een positieve intentie. De onderzoekers ondersteunen op basis van hun bevindingen met de recycling-actie de opvatting van Verhallen en Pieters (1984) dat het model van beredeneerde actie (Fisbein en Ajzen) in de regel teveel nadruk legt op lange termijn voordelen en te weinig op de korte termijn nadelen. Klandermans (1987) stelt dat de sociale psychologie onvoldoende aandacht schenkt aan het beïnvloeden van zeer grote aantallen mensen. Ten aanzien van sociale dilemma's schiet de sociale psychologie tekort omdat er niet expliciet aandacht geschonken wordt aan het gedrag van anderen. Klandermans concludeert dat de realisering van een collectief belang mede afhankelijk is van de gedragskeuzen van anderen: de verwachting omtrent de keuzen van anderen beïnvloedt de eigen gedragskeuze. Voor de strategie van een beïnvloedingscampagne betekent dit dat de inhoud van de boodschap zekerheid moet verschaffen over het gedrag van anderen. We denken hierbij aan de mogelijkheid van een waarneembare feedback. 
Boniecki (1978), Stern (1978), McKnight (1978) hebben een verklaring gezocht voor de onvoldoende motivatie om een offer te brengen voor een gemeenschaplijk doel. $\mathrm{Zij}$ komen allen tot dezelfde conclusie: de persoonlijke daad wordt niet als een doeltreffend middel ervaren; de persoonlijke inbreng wordt beschouwd als een druppel op een gloeilende plaat. Dezé bevindingen sluiten nauw aan bij de instrumentele-motivatie-theorie namelijk dat de motivatie voor de handeling zwakker zal zijn naarmate de waarschijnlijkheid om middels de handeling het gestelde doel te bereiken kleiner is. Nuttin (1981) stelt dat dergelijke pogingen bij voorbaat tot mislukken gedoemd zijn omdat de persoon niet in staat is om controle uit te oefenen over zijn handelen; hij voelt zich machteloos omdat de persoon geen kans ziet om zelf middelen aan te wenden om het probleem op te lossen. Bovendien is volgens Nuttin de behoefte tot functioneren in actieve zin afwezig, dat will zeggen de behoefte in te werken op de omgeving, de situatie te beheersen, competent en efficiënt te zijn in de interactie met de omgeving. Nuttin ziet dan ook maar één oplossing namelijk het instellen van een supra-individuele entiteit die in staat is om collectieve daden te coördineren: "Een realistische actie om de mensen te motiveren datgene te doen wat ze zelf als een sociale noodzaak beschouwen (de vervuiling tegenhouden bijvoorbeeld), moet dus worden uitgevoerd door middel van zaken die de mens zelf heeft ingesteld om dit soort doelen te bereiken, namelijk een institutionele of wettelijke reglementering, en niet door een direct beroep op de individuele gemotiveerdheid van de mensen".

Veen en Wilke ( 1984) gaan er van uit dat in sociale dillemma-situaties de motivationele oriëntaties mede bepaald worden door een competitieve of coöperatieve instelling van de persoon. Zij baseren zich op de resultaten van Pruitt en Kimmel (1977), die een doelverwachtingstheorie hebben geformuleerd over het ontstaan van samenwerkingsrelaties in situaties met (gedeeltelijk) tegengestelde belangen. $\mathrm{Zij}$ stellen dat samenwerking in sociale dillemma-situaties voornamelijk een kwestie is van het beschikken over inzichten. Bijvoorbeeld ten aanzien van de verwachting dat wanneer men zelf coöperatief is ingesteld, anderen zich ook coöperatief opstellen, dat door zelf samen te werken, de bereidheid van anderen toeneemt dat ook te doen en dat de realisering van een gemeenschappelijk doel mede afhankelijk is van het gedrag van de ander. Thibaut en Kelley (1959) beschouwen de mens als een actief wezen dat doelen nastreeft, na grondige afweging van de verschillende alternatieven. Doelen die het 
hoogst gewaardeerd worden zullen in de regel geprefereerd worden: de persoon kiest dat alternatief dat de hoogste verwachte uitkomst heeft. De genoemde auteurs veronderstellen dat een persoon beschikt over een aantal cognities, die aan het bereiken van het doel gerelateerd zijn. De persoon moet dus op basis van de beschikbare cognities verbanden weten te leggen tussen de doelen en de mogelijke gevolgen. Thibaut en Kelly maken een onderscheid tussen de opbrengst(en) van het huidige gedrag en de verwachte uitkomsten van het alternatieve gedrag. De keuze die men maakt, is gebaseerd op de inschatting die men makkt van het mogelijke verschil tussen beide gedragsalternatieven (zie ook hoofdstuk 3). Ten aanzien van sociale dilemma's betekent dit dat men een betrouwbare taxatie moet maken van het gedrag van anderen om op den duur eigen voordeel te kunnen verwerven. Deze afweging zal alleen plaatsvinden indien men voldoende vertrouwen heeft in het realiseren van een gemeenschappelijk doel. Bovendien moet er sprake zijn van een zekere mate van wederkerigheid: men moet er van overtuigd raken dat anderen een soortgelijke afweging zullen maken die ten gunste van het collectief belang uitvalt.

Toch zijn er vele auteurs (Jaspers, 1978; Klandermans, 1984), die een lans breken om campagnes waar collectieve belangen mee gemoeid zijn, te implementeren via sociale netwerken. Deze schaalverkleining schept de mogelijkheid om sociale normen als determinanten van het gewenste gedrag beter tot zijn recht te laten komen. In kleinere sociale eenheden is niet alleen het gedrag beter zichtbaar, maar is ook meer sprake van sociale controle en onderlinge solidariteit. Een mooi voorbeeld van de sociale netwerkbenadering is het voorlichtingsexperiment aan achterstandsgroepen (Weenig, 1989).

Rogers (1983) hanteert het convergentiemodel om de verspreiding van communicatieboodschappen in te kaderen in de structuur van sociale netwerken. Hij wijst op het belang van de relaties van individuen binnen een sociaal systeem. Het in kaart brengen van deze relaties binnen het sociaal systeem kan duidelijkheid verschaffen over de communicatiestructuur. Ten aanzien van publiekscampagnes met een collectief doel zijn gedecentraliseerde verspreidingssystemen te prefereren boven gecentraliseerde systemen (eenrichtingsverkeer van expert naar gebruiker). Bij gedecentraliseerde systemen vindt verspreiding plaats via horizontale netwerken, is controle door de cliënt mogelijk en er is meer ruimte voor eigen initiatief. Bij gedecentraliseerde verspreidingssystemen is - naast de belangrijke positie van de opinle- 
leider - vooral "re-invention" mogelijk, dat wil zeggen dat het lid van de doelgroep de innovatie kan wijzigen of aanpassen aan de eigen situatie.

Al eerder is gewezen op het belang van gratificaties, die aan het opvolgen van boodschappen met een collectief doel verbonden zijn. Doorgaans weegt het individu de kosten en de baten tegen elkaar af. Bij activiteiten met een collectief belang zal de keuze voor eigen belang op de korte termijn aantrekkelijker zijn dan de keuze voor een collectief belang op de langere termijn. De voorlichtingsstrategie zal er dus op gericht moeten zijn om de collectieve belangen duidelijker te profileren en de individuele belangen te ontmantelen. Klandermans (1987) suggereert een interventie met "selectieve opbrengsten". Al naar gelang de aard van het sociale dilemma kunnen personen deze alleen verwerven door een keuze te maken voor het collectieve belang danwel de collectieve opbrengsten te vergroten. Ook hier geldt dat de mate van motivatie van doorslaggevende betekenis is als het gaat om een afweging tussen beide mogelijkheden. Het realiseren van een collectief belang vertoont in vele opzichten een treffende gelijkenis met de diffusie van innovaties. Bij de implementatie van publiekscampagnes dient men zich rekenschap te geven van de verwachting omtrent het gedrag van anderen en de gepercipieerde effectiviteit. De diffusie van innovaties wordt ook in zekere mate bepaald door een aantal percepties, namelijk de mate waarin de innovatie voordeel of risico met zich meebrengt; de mate waarin de innovatie past binnen de waarden, ervaringen en behoeften; de complexiteit van het uit te voeren gedrag; het al dan niet waarneembaar zijn van het gedrag en de consequenties die daaruit getrokken worden door de sociale omgeving; de toetsbaarheid (kan men ervaring opdoen voor men beslist tot acceptatie of verwerping).

\subsection{Slotbeschouwing}

In het voorafgaande hebben we voorlichting gedefinieerd als informatie dienstbaar maken voor een (sub)populatie teneinde een bijdrage te leveren aan het oplossen van individuele en/of maatschappelijke problemen. De keuze voor het woord dienstbaar heeft enerzijds te maken met het feit dat dit "neutrale" woord vele activiteiten kan 
beslaan, anderzijds komt in dit woord het (uiteindelijke) belang van de ontvanger(s) goed tot uitdrukking.

Conform de definitie is voorlichting altijd doelgericht. De concretisering van deze doelgerichtheid is afhankelijk van de aard en omvang van het probleem waarvoor de voorlichter zich geplaatst ziet. We hebben twee grondvormen van voorlichting onderscheiden, namelijk: intentionele voorlichting waarbij de voorlichter uitdrukkelijk veranderingen bij het publiek wil bewerkstelligen en faciliterende voorlichting, waarbij de voorlichter vrijblijvender te werk gaat en informatie aanbiedt als dienstverlening of als service.

Voorts hebben we gewezen op de functie van voorlichting als beleidsinstrument. Wil voorlichting als beleidsinstrument vruchtbare resultaten opleveren dan dient deze ingebed te zijn in de beleidscyclus of om met de woorden van Van Woerkum (1990) te spreken: "De kracht van voorlichting is sterk afhankelijk van de kracht van het overige beleid."

Ter afsluiting van dit hoofdstuk hebben we de aandacht gevestigd op de complexiteit van voorlichting. Aan de hand van een sociaal dilemma-probleem hebben we geillustreerd dat achter het gedrag van mensen allerlei sociaal-psychologische processen schuilgaan, die nadere bestudering behoeven om mensen te motiveren tot ander gedrag. In de navolgende hoofdstukken zal worden nagegaan wat de oorzaken van gedrag zijn en hoe gedrag - direct of indirect - beìnvloed wordt door sociale determinanten. 



\title{
Hoofdstuk 2 Gezondheidsvoorlichting als modaliteit van intentionele voorlichting
}

\author{
2.1 Inleiding \\ 2.2 GVO als functie van preventie \\ 2.3 GVO als vorm van intentionele voorlichting \\ 2.4 De systematiek van intentionele voorlichting \\ 2.5 De doelgerichtheid van intentionele voorlichting \\ 2.6 De planmatigheid van intentionele voorlichting \\ 2.7 Slotbeschouwing
}

\section{$2.1 \quad$ Inleiding}

De ontwikkeling van Gezondheidsvoorlichting en -opvoeding (GVO) is serieus ter hand genomen toen bleek dat het gedrag van mensen in vele gevallen de oorzaak was van allerlei ziekten en aandoeningen. Alras werd duidelijk dat voor gedragsziekten geen probaat geneesmiddel voor handen was. Door de explosieve toename van hart- en vaatziekten, kwaadaardige nieuwvormingen, verslavingen, ziekten veroorzaakt door aanslagen op het natuurlijk milieu etc. drong - in de zeventiger jaren - het besef door dat de curatieve gezondheidszorg tekort zou schieten in het terugdringen van deze ziekten. Met nog meer geld, mensen en voorzieningen kunnen weliswaar de symptomen van deze gedragsziekten tijdelijk bestreden worden, maar de medische technologie zal niet in staat zijn om de opmars van deze welvaartsziekten definitief te stuiten. De term welvaartsziekten verwijst naar allerlei vormen van ongezondheid, waarbij het gedrag van 
mensen veelal wordt aangewezen als oorzaak van kwalen, aandoeningen en afwijkingen en die direct of indirect het gevolg zijn van de toegenomen welvaart. Het leek erop alsof mensen in de verzorgingsstaat niet meer in staat waren hun eigen weelde te dragen en dientengevolge de verantwoordelijkheid voor lijf en leden overdroegen aan medische zorgverleners. Termen als medicalisering en hospitalisering raakten in zwang. Ofschoon er een kern van waarheid schuilt in dit gegeven, hebben epidemiologische onderzoekingen deze gedachte niet empirisch kunnen onderbouwen. Wel bleef overeind dat heterogene gedragsfactoren debet waren aan het ontstaan van diverse ziekten en aandoeningen. Een gedragswetenschappelijke benadering zou uitkomst moeten brengen in die zin dat mensen zich gezonder moesten gaan gedragen, zodanig dat ziekten werden voorkomen of in een vroegtijdig stadium genezen konden worden.

Preventieve gezondheidszorg werd het credo.

\subsection{GVO als functie van preventie}

GVO wil determinanten van gedrag die de gezondheid bedreigen, elimineren en die factoren bevorderen, die een gunstige uitwerking hebben op het gezondheidsgedrag van de mens. Deze veranderingen gericht op het optimaliseren van de kwaliteit van het bestaan (Green, 1978, 1980) wil men bewerkstelligen middels gerichte beïnvloedingspogingen, die gegrondvest zijn op communicatie. GVO probeert de gezondheid te bevorderen door mensen te motiveren tot ander "gezonder" gedrag of tot handhaven van bestaand gezond gedrag (Kok, 1987).

In het dagelijks spraakgebruik worden de termen voorlichting en preventie als equivalent gezien. Echter voorlichting is een modaliteit van preventie. De doelstellingen van gezondheidsvoorlichting en preventie zijn nagenoeg identiek namelijk het voorkomen van het ontstaan (primaire preventie), het verminderen of herstellen (secundaire preventie) en het verlichten of dragelijk maken van gezondheidsproblemen (tertiaire preventie). Preventie bestrijkt een ruimer terrein; ook regelgeving en het treffen van voorzieningen en voorwaardenscheppende activiteiten rekenen we tot preventie. Als voorbeeld van regelgeving noemen we de wettelijke verplichting tot het dragen van veiligheidsgordels in auto's. Als voorbeeld van voorwaardenscheppende activiteiten geldt het verstrekken van schone injec- 
tienaalden aan drugsverslaafden ter bestrijding van infecties. "Blijf van mijn lijf"-huizen zijn voorzieningen in de preventieve sfeer om erger te voorkomen.

Rouwenhorst (1977), de stuwende kracht achter de ontwikkeling van GVO in de zestiger en zeventiger jaren, benaderde GVO vanuit een functionele invalshoek. Volgens haar kunnen aan de zorg voor gezondheid binnen het sociale systeem drie functies onderscheiden worden, namelijk:

1. de dwingende functie in de vorm van voorschriften en daarop berustende maatregelen;

2. de aanbiedende functie in de vorm van het beschikbaar stellen van voorzieningen en diensten;

3. de participatie-wervende functie middels educatieve interventies.

Functies moeten in haar visie opgevat worden als noodzaak; waarmee feitelijk wordt aangegeven dat GVO een essentiële component is voor de oplossing van de huidige gezondheidsproblematiek Met de participatie-wervende functie wil zij tot uitdrukking brengen dat er een beroep wordt gedaan op het verantwoordelijkheidsgevoel van de persoon in kwestie. Het gaat niet zozeer om het vrijblijvend aanbieden van hulp of informatie, maar veeleer gaat het om het betrekken van de mensen bij het oplossen van de eigen gezondheidsproblemen en die van de samenleving. Achter deze zienswijze gaat toch een ideaaltypische benadering schuil, namelijk het idee dat gezondheidsoverwegingen (bijvoorbeeld variabelen in het Health Belief Model als ernst en kwetsbaarheid van een ziekte) bepalend zijn voor het gedrag van mensen. Recente inzichten (Jonkers et al, 1988) leggen meer nadruk op persoonlijke voordelen van het gewenste gedrag (bijvoorbeeld de uitstraling van een blakende gezondheid of een perfecte conditie) en achten gezondheidsoverwegingen dikwijls van ondergeschikt belang. De maatschappelijke en persoonlijke voordelen van het ongewenste gedrag blijken in vele gevallen zwaarwegender dan de nadelen (gezondheidsrisico's). GVO-interventies zouden daarom als vertrekpunt meer nadruk moeten leggen op de persoonlijke voordelen en het eigen belang voor de voorgelichte.

GVO kan ook benaderd worden vanuit de visie van Health Promotion en wordt daarmee een onderdeel van het brede begrip gezondheidsbevordering. Bij Health Promotion gaat men er vanuit dat het 
gedrag van het individu (en de haar of hem ter beschikking staande gezondheidszorgdiensten) niet alleen de gezondheidstoestand bepalen. Ook andere factoren spelen daarbij een bijzondere rol. Dit zijn zaken als fysieke omgeving (milieuvervuiling, huisvesting etc.), maatschappelijke omgeving (opleiding, werk, sociale netwerken etc.) en endogene factoren (genetische factoren). Streeft men naar verbetering van de gezondheidstoestand dan zijn het deze factoren die integraal in de beleidsvoorbereiding en -uitvoering aan de orde moeten worden gesteld. Health Promotion is een integrale beleidsvisie, die stelt dat gezondheid binnen alle maatschappelijke en beleidssectoren een zekere prioriteit moet hebben. Gezondheid moet intersectoraal benaderd worden. Met de term intersectoraal wordt bedoeld dat verschillende elkaar aanvullende benaderingen nodig zijn om een optimale gezondheid van de bevolking te bewerkstelligen: activiteiten op terreinen als onderwijs, welzijnswerk, wetgeving, fiscale maatregelen, etc.. Figuur 2.1 toont duidelijk de positie van Health Promotion in de maatschappelijke context.

Ofschoon in dit model geen directe relatie gelegd wordt tussen gezondheid en gedrag, wordt aan GVO in het Health Promotion concept een bijzondere plaats toegekend. GVO zou zich niet moeten beperken tot het voorlichten over het functioneren van het lichaam en het zinvolle en bewuste gebruik van de beschikbare gezondheidszorgvoorzieningen, maar zou zijn vleugels moeten uitslaan over beleidskaders op nationaal, regionaal en locaal niveau. Beleidsmakers, bestuurders, managers en politici zouden veel meer en beter geïnformeerd moeten worden over de belemmerende en begunstigende factoren die van invloed zijn op gezondheid. Zij zijn het immers die direct invloed uit kunnen oefenen op de kwaliteit van het bestaan. De Leeuw (1988) ijvert ervoor dat juist deze kwaliteit van GVO in de toekomst tot bloei zou moeten komen. 


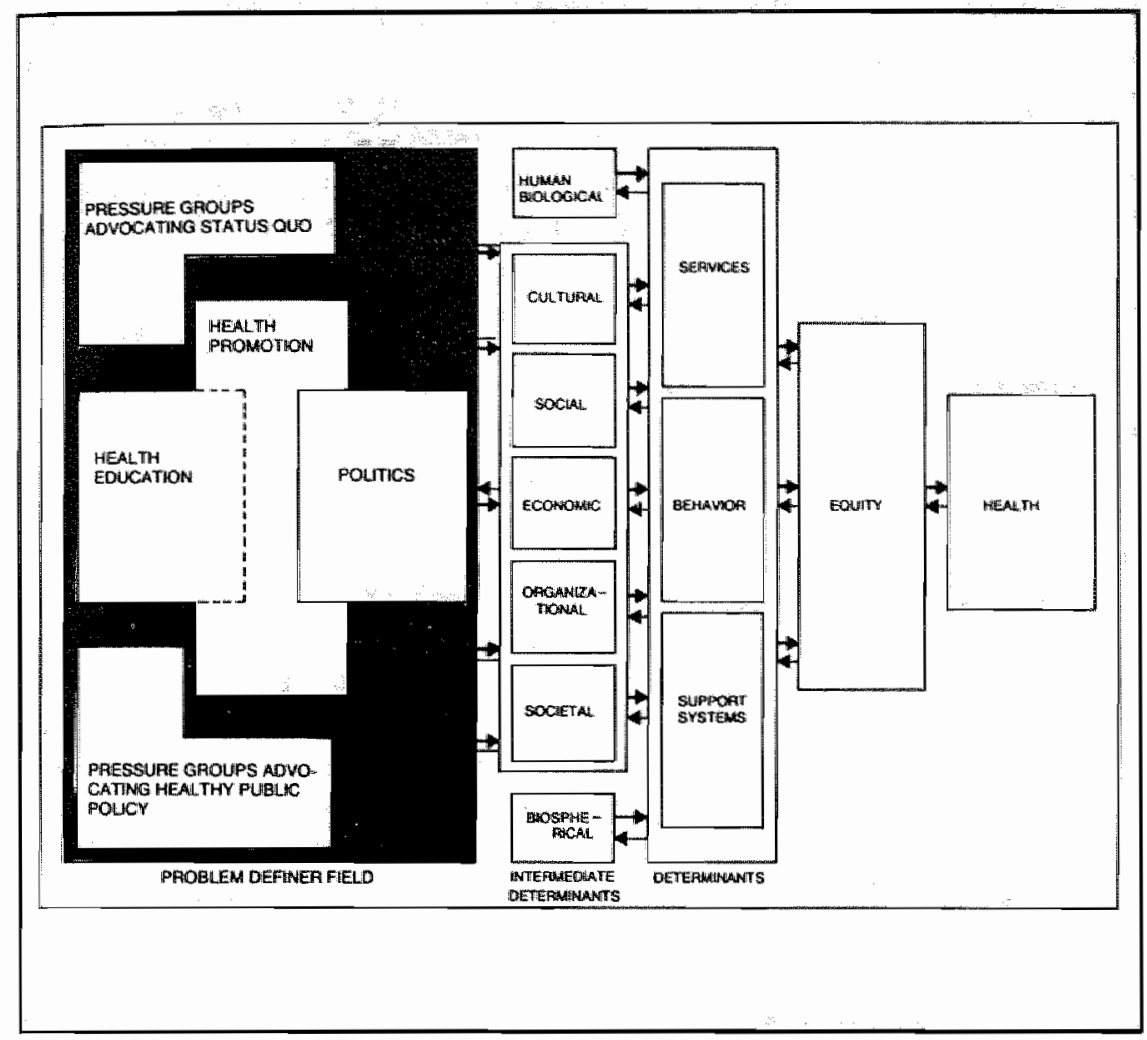

Figuur 2.1 Health Promotion in de maatschappelijke context. Bron: De Leeuw, 1989, pag. 23.

\subsection{GVO als vorm van intentionele voorlichting}

Een tiental jaren geleden werd GVO met argusogen bekeken door hulpverleners en publiek. Voor medici kwam GVO nogal bemoeizuchtig over: op wetenschappelijk niveau de frictie tussen de medische wetenschappen en de gedragswetenschappen, in de praktijk de frictie tussen artsen, die volgens een medisch model werken en GVO'ers, die meer een gedragsmodel hanteren. Het publiek betitelde GVO als betuttelend. Alles wat lekker, fijn of plezierig is mag niet meer; meer bewegen, minder vet, matig met alcohol, voorzichtig met vrijen, niet 
te veel eieren, etc. Thans is men wat genuanceerder gaan denken over GVO. Bij medici en paramedici is het besef doorgedrongen dat de kwaliteit van de zorg niet alleen meer bepaald wordt door het medisch/technisch handelen. Ook het communicatieve handelen wordt thans als kwaliteitscriterium gehanteerd. voorlichting aan patiënten dient een geïntegreerd deel van het therapeutisch handelen te zijn. GVO is het publiek tegemoet gekomen door zich beter te profileren als hulp bij het verkrijgen van vaardigheden en inzichten om verantwoorde keuzen te maken ten aanzien van eigen gezondheidsproblematiek. Zo gaat ook de wens van de mondige patiënt in vervulling om bejegend te worden als gelijkwaardige gesprekspartner.

GVO heeft in het verleden wellicht teveel gepretendeerd dat verandering van kennis de oplossing voor verschillende, uit het oogpunt van gezondheid ongewenste gedragingen zou zijn. Men leefde in de veronderstelling dat kennisvermeerdering op den duur zou leiden tot gedragsverandering. Het staat buiten kijf dat kennisvermeerdering (hier bedoeld in de zin van het doorlopen van een leerproces bijvoorbeeld conditonering, modelling) een noodzakelijke voorwaarde is voor gedragsverandering. Bij GVO gaat het niet alleen om het overdragen van kennis maar veeleer om de vraag hoe die kennis in het dagelijks handelen toegepast moet worden om zich blijvend gezond te gedragen. Wellicht dat het onderscheid tussen een gezondheidsprobleem en een GVO-probleem in deze opportuun is. Aan de hand van een voorbeeld wordt dit onderscheid verhelderd. Roken is een gezondheidsprobleem omdat onomstotelijk vaststaat dat de kans op het krijgen van longkanker aanmerkelijk wordt verhoogd. Het GVOprobleem betreft de vraag hoe men mensen een effectieve methode aan de hand kan doen zodanig dat zij structureel, dat wil zeggen blijvend van het roken afkomen. Bij intentionele voorlichting i.c. gezondheidswoorlichting dient het streven dus niet alleen gericht te zijn op gedragsverandering (het stoppen met roken) maar vooral op gedragsbehoud: het bestendigen van de gedragsveranderingen op een zodanige wijze dat de verandering beklijft in het dagelijks doen en laten. Het is de GVO-er die een bijdrage dient te leveren aan een oplossing die verankerd wordt in gedrag.

GVO is de vertaling van de angelsaksische term "health education". GVO is net als voorlichtingskunde een toegepaste wetenschap die gevoed wordt door bevindingen en theorieën uit de gedragswetenschappen. De vertaling van "health education" in gezondheidsvoor- 
lichting en -opvoeding wordt niet door iedereen met instemming begroet want de term doet vermoeden dat enerzijds sprake is van opvoeding en anderzijds van voorlichting. Voorlichting wordt dan opgevat als incidentele informatie-overdracht en opvoeding wordt gezien als een pedagogisch-didactische activiteit, die zich over een ruimere tijdsperiode uitstrekt. In wezen volgt GVO de klassieke definitie van voorlichting: voorlichting is bewust gegeven hulp bij menings- of besluitvorming door middel van communicatie waarbij het belang van de voorgelichte centraal staat (Van den Ban, 1985). De soorten voorlichting, die Van Woerkum (1987) onderscheidt, namelijk vormende/educatieve voorlichting, informatieve voorlichting en persuasieve voorlichting, komen binnen GVO alle drie aan de orde. De keuze voor een van deze soorten voorlichting is afhankelijk van de doelstelling die men wil realiseren en de problematiek die men wil oplossen. De educatieve component komt bij GVO zowel in de informatieve als in de persuasieve voorlichting aan bod. Het door ons aangebrachte onderscheid tussen faciliterende en intentionele voorlichting komt in grote lijnen overeen met de informatieve respectievelijk persuasieve voorlichting zoals die door Van Woerkum is beschreven. Op een enkele uitzondering na (bijvoorbeeld de "informed consent-problematiek" bij patiëntenvoorlichting) kunnen we GVOactiviteiten rekenen tot de intentionele voorlichting. Immers bij intentionele voorlichting gaat het om een opzettelijke poging tot beinvloeding van het kennisniveau, de attitude of het gedrag, dat uiteindelijk zal moeten resulteren in gedragsbehoud. Bij de verwezenlijking van die beïnvloedingspoging maakt men doorgaans gebruik van educatieve interventies. Kenmerkend voor educatieve interventies die de toets der kritiek kunnen doorstaan, is dat men systematisch, planmatig en doelgericht te werk moet gaan. In het navolgende worden deze fundamentele pijlers van intentionele voorlichting aan een nadere beschrijving onderworpen en wordt aangegeven hoe ze binnen gezondheidsvoorlichting concreet vorm worden gegeven. Wellicht ten overvloede zij opgemerkt dat onder educatieve interventies een brede waaier van activiteiten schuil kan gaan; het gaat niet uitsluitend om informatie-overdracht, veelal gaat informatie-overdracht gepaard met het beschikbaar stellen van voorzieningen en materialen, trainingen, etc.

In paragraaf 1.4 hebben we er al op gewezen dat voorlichting als instrument van beïnvloeding zowel bovengeschikt, ondergeschikt als nevengeschikt kan worden aangewend. 


\section{De systematiek van intentionele voorlichting}

Voorlichting is geen panacee, geen Haarlemmerolie anno 1698, die voor ieder probleem verlichting of een oplossing biedt. GVO beschikt over een beperkt instrumentarium om gezondheidsproblemen te lijf te gaan. Deze instrumenten moeten dan ook nog adequaat worden aangewend om effectief te zijn. Een veel voorkomende blunder, die we in de voorlichtingspraktijk signaleren, is het feit dat men voor elk willekeurig probleem een onmiddellijke oplossing heeft. Bestuurlijke kaders en beleidsfunctionarissen plegen voorlichting niet te gebruiken in de trant van "vroeg op weg en traagies varen, helpt de tijd en rampen sparen". Zij neigen er toe om, na vluchtige kennismaking met een probleem, snel tot actie over te gaan, zonder zich voldoende te realiseren wat de oorzaken van het probleem zijn en zonder zich af te vragen of voorlichting wel het meest geschikte middel is. Voorlichters worden dan te pas en te onpas opgezadeld met het gigantische probleem om de gemoederen te sussen met informatie. Meestal kiest men dan ook nog voor het meest voor de handliggende (en goedkoopste) middel namelijk schriftelijk informatiemateriaal. Dit verklaart de enorme hoeveelheid folders die overal verkrijgbaar zijn: op iedere toonbank, bij ieder loket en in iedere wachtkamer liggen ze voor het grijpen. De problemen met betrekking tot gezondheid, welzijn en veiligheid zijn zo divers van aard dat slechts in zéer uitzonderlijke gevallen een instant-oplossing voorhanden is. Gezondheidsproblemen dienen eerst zorguuldig geanalyseerd te worden alvorens men overgaat tot het bedenken van een oplossing. De oplossing kan gezocht worden in bijvoorbeeld het treffen van passende maatregelen zoals sanctionering, regelgeving of het aanbrengen van bepaalde voorzieningen. Ook voorlichting, eventueel gepaard gaande met bovengenoemde mogelijkheden, kan in vele gevallen de juiste oplossing zijn. Degene die met voorlichting een bepaald doel nastreeft, zal systematisch te werk moeten gaan.

De systematiek van GVO kent vier stappen namelijk:

1. probleemanalyse: wat is de relatie tussen het gezondheidsprobleem en menselijk gedrag?

2. gedragsdeterminantenanalyse: wat zijn de determinanten van dat gedrag?

3. gedragsbeïnvloeding: hoe is dat gedrag te beïnvloeden?

4. evaluatie: wat is het effect van die beinvloeding? 


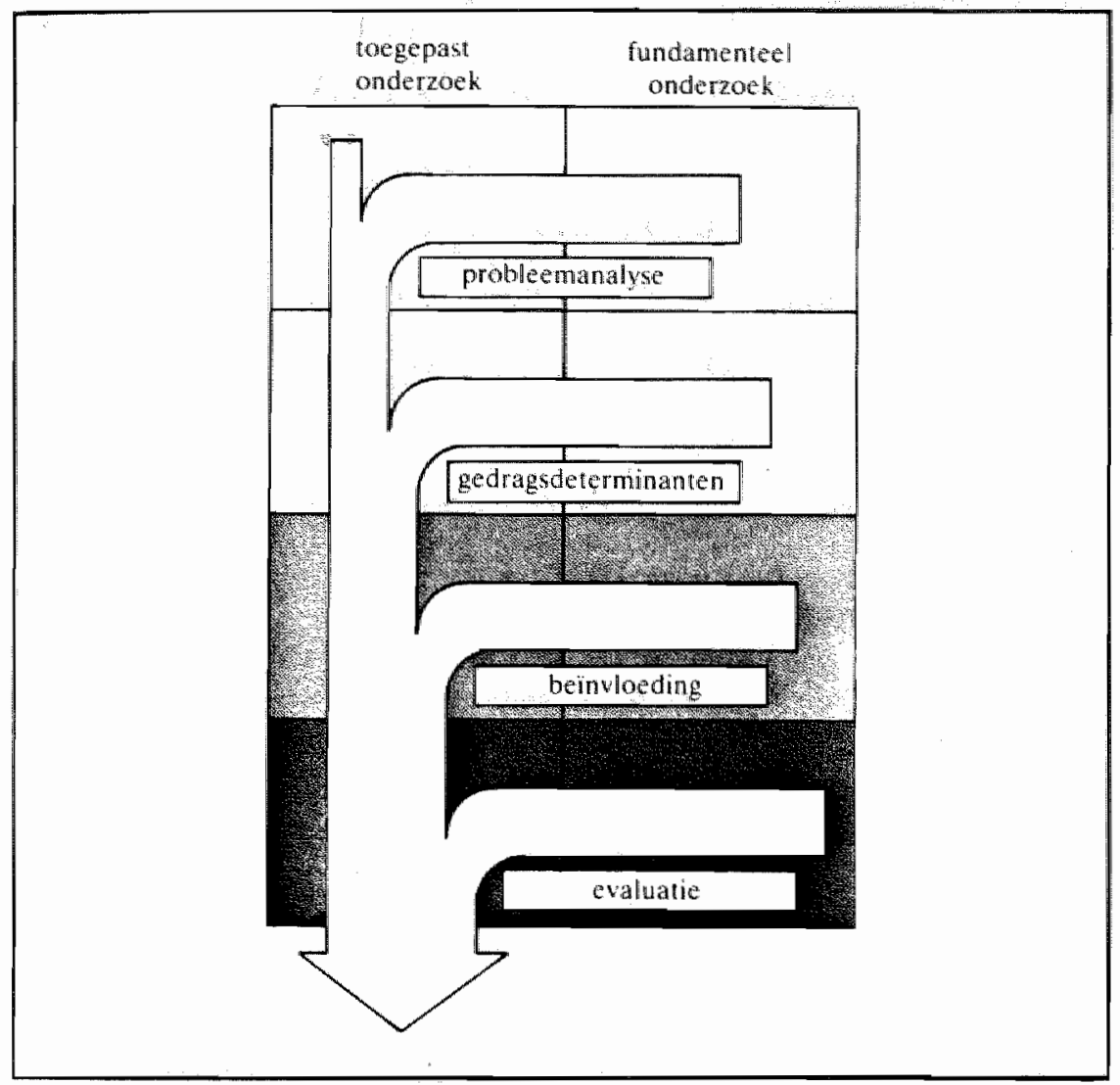

Figuur 2.2 Matrix van GVO-onderzoek

Bron: Kok, 1987, pag. 3.

\section{Ad 1 probleemanalyse}

Uitgangspunt van iedere interventie is dat men tracht gezondheidsproblemen te verminderen of op te lossen door wijziging van gedrag, attitude of kennis. Daarom is het van groot belang om te achterhalen of er werkelijk een relatie is tussen gedrag en probleem. De eerste vraag die bij de probleemanalyse aan de orde wordt gesteld, betreft de ernst van het probleem. Helderheid dient verkregen te worden 
over wat het probleem is, waarom het een probleem is, voor wie het een probleem is, voor wie het probleem gevolgen heeft en welke sociale en/of economische consequenties het probleem heeft voor de samenleving in zijn geheel of delen daarvan. Het is aan geen twijfel onderhevig dat veel gezondheidsproblemen niets of nauwelijks iets met het gedrag van individuele mensen van doen hebben. We denken bijvoorbeeld aan de door gif verontreinigde grond of aan geestelijke gezondheidsproblemen ten gevolge van werkloosheid. Aan dit soort problemen kan GVO betrekkelijk weinig doen; hooguit kan men aansturen op structurele oplossingen op politiek niveau. GVO kan alleen worden aangewend als het gedrag van mensen de oorzaak is van het probleem. Wellicht ten overvloede zij er op gewezen dat gedrag in de meest ruime zin moet worden opgevat. Het gaat niet alleen om feitelijk waarneembare gedragingen, maar ook om factoren die aan dat gedrag voorafgaan of om zaken die zich in de geest van mensen kunnen afspelen. De resultaten van de probleemanalyse moeten duidelijk aangeven hoe belangrijk het probleem is, met andere woorden de analyse moet inzicht verschaffen in de prevalentie en incidentie van het probleem en kennis aandragen over specifieke gedragsmatige risicofactoren. Op basis van deze epidemiologische en etiologische gegevens dient te worden vastgesteld of en in hoeverre, gedragingen als een oorzakelijke factor kunnen worden aangemerkt.

Bouter en Van Dongen (1991) verdelen, in navolging van Green (1980), de probleemanalyse in een drietal diagnosen, te weten, de gedragsdiagnose, de epidemiologische diagnose en de sociale diagnose. Bij de sociale diagnose gaat het om een inventarisatie van de psychosociale en de sociaal-economische consequenties van het gezondheidsprobleem. De epidemiologische diagnose richt zich op de omvang, de ernst en de spreiding van het gezondheidsprobleem. Bij de gedragsdiagnose wordt gekeken naar gedragsmatige oorzaken die ten grondslag liggen aan het in de epidemiologische diagnose geselecteerde gezondheidsprobleem. Daarbij is het niet alleen van belang om de kwalitatieve aspecten te onderzoeken (het feit of er een relatie bestaat tussen het gedrag en het gesignaleerde probleem) maar ook het kwantitatieve aspect verdient de nodige aandacht, namelijk de vraag hoe sterk of zwak de relatie tussen het menselijk gedrag en het probleem is. 


\section{Ad 2 de gedragsdeterminantenanalyse}

De tweede stap in het systematische proces is de analyse van de gedragsdeterminanten. Het gaat hier om de vraag welke determinanten of factoren het ongewenste gedrag veroorzaken of het gewenste gedrag belemmeren. We moeten dus de vraag beantwoorden welke redenen mensen hebben voor het vertoonde ongewenste gedrag. Het kan bijvoorbeeld heel goed mogelijk zijn dat een gebrek aan kennis over (andere) gedragsalternatieven ontbreekt. Het kan echter ook voorkomen dat problemen van financiële aard gezond gedrag in de weg staan, of dat men door anderen in zekere mate gedwongen wordt tot het verrichten van bepaalde ongezonde handelingen. Het is noodzakelijk om zorgvuldig - en tot in details - na te gaan wiens gedrag in het geding is en waar en wanneer dit vertoond wordt. Het kan bijvoorbeeld blijken dat bij sommige sporten veel meer blessures optreden dan bij andere, of dat bij sommige groepen mensen blessures van geheel andere aard of localisatie plaatsvinden.

Men dient er bovendien op bedacht te zijn dat het - door de bank genomen - niet gaat om een soort of vorm van gedrag. Het gedrag is een samenklontering van verschillende gedragingen, een reeks van procesmatige activiteiten, die men ontplooit en die ingegeven zijn door bijvoorbeeld tijd, positie en situatie. De gedragsdeterminantenanalyse impliceert dus het ontleden van gedrag in segmenten. Een voorbeeld: in een folder over borstzelfonderzoek wordt uitvoerig een methode beschreven hoe vrouwen een knobbeltje kunnen opsporen. Zijdelings wordt gemeld dat wanneer vrouwen het vermoeden hebben dat er iets mis is of wanneer er inderdaad een knobbeltje wordt gevonden, ze naar de huisarts moeten gaan. Dit laatste wordt met enkele zinnen afgedaan. Dat een dergelijke folder uitstelgedrag in de hand werkt is niet verwonderlijk. In het geval van borstzelfonderzoek zijn twee gedragingen in het geding, namelijk het onderzoeken van de borsten en het naar de huisarts gaan. Dat aan dit laatste vele indringende overwegingen ten grondslag liggen spreekt voor zich. Voorlichting over borstzelfonderzoek schiet zijn doel voorbij als niet aan alle relevante gedragsaspecten aandacht wordt geschonken. Kortom het is van belang om te achterhalen wat er vooraf gaat, hoe het ter plekke gebeurt en hoe men achteraf de ervaringen weergeeft. Veel voorlichtingsactiviteiten kunnen de toets der kritiek niet doorstaan en laten slechte resultaten zien omdat een zorgvuldige analyse van de determinanten van het gewenste en ongewenste gedrag 
achterwege is gelaten (Green en Lewis, 1986; Jonkers, 1988; Becker en Joseph, 1988).

Tot gedragsdeterminanten worden gerekend: cognities, sociale invloed, attitudes en gedragsmogelijkheden. Ter verduidelijking worden deze termen nader toegelicht.

Een attitude is een afweging van alle voor- en nadelen die een persoon aan een bepaald gedrag koppelt. De afweging die gemaakt wordt is een aangeleerde dispositie om op een systematische gunstige of ongunstige wijze te reageren op een object of gedrag. In wezen gaat het dus om consequenties die aan bepaald gedrag verbonden zijn, uitgedrukt in voor- en nadelen. Een attitude is niet zuiver rationeel maar kan gebaseerd zijn op diepgewortelde waarden- en normenpatronen en irrationele overtuigingen. Zo wordt bijvoorbeeld in het "Health-Belief-Model" (Janz en Becker, 1984) gedrag gezien als de resultante van de gevolgen van de dreiging die men ervaart wanneer men meent kwetsbaar te zijn voor een ernstige aandoening. Met het meten van attitudes kan men voorspellingen doen hoe iemand over een object of gedrag denkt en voelt en hoe hij zich waarschijnlijk zelf zal gedragen. De waarschijnlijkheid komt onder andere voort uit het feit dat het individu zijn mening of gedrag toetst aan de normen en waarden van mensen die in zijn directe omgeving verkeren of die hij om een of andere reden hoog acht.

Normen en waarden zijn begrippen die veelvuldig in de literatuur over voorlichting gebezigd worden. Kennelijk gaat men ervan uit dat daarmee een reeks gedragsregels bedoeld wordt die door een bepaalde populatie gehanteerd of gerespecteerd worden. Dat in de voorlichting rekening gehouden moet worden met de geldende waarden en normen is zo vanzelfsprekend dat daarover nauwelijks discussie bestaat. Door in te druisen tegen bestaande normen of vigerende waarden te bagateliseren, zou men weerstand kunnen oproepen en zodoende het gewenste effect van de voorlichting teniet kunnen doen. Het is overigens niet geheel uitgesloten dat normen het object van verandering kunnen zijn, bijvoorbeeld het beïnvloeden van de subjectieve norm, dat wil zeggen het veranderen van de invloed van de sociale omgeving. Het komt nogal eens voor dat men het heeft over verandering van normen terwijl men in feite verandering van attitudes of beliefs (veronderstellingen) bedoelt. Deze Babylonische spraakverwarring is een reden om meer helderheid over dit begrip te verschaffen. Een nadere beschrijving van de begrippen is meer gerechtvaardigd als men bedenkt dat zij in belangrijke mate het 
gedrag van mensen reguleren. In de theorie van Fishbein en Ajzen (1975) en Ajzen en Fishbein (1980) wordt aan de invloed van sociale normen veel betekenis toegekend. Het gedrag van mensen wordt bij voortduring beoordeeld door anderen en de wijze waarop anderen denken over voorgenomen handelingen is bepalend voor het vertoonde gedrag. In het model van Fishbein en Ajzen geeft de subjectieve norm aan wat de invloed is van de sociale omgeving op het gedrag van een individu. De subjectieve norm bestaat uit twee elementen namelijk "normatieve beliefs" (de door een persoon waargenomen opvattingen van belangrijke anderen) en "motivation to comply" (de mate van instemming met de mening van belangrijke anderen). Doordat binnen groepen veelal min of meer stabiele waarden en normen heersen, bestaan er aldus ook betrekkelijk stabiele gedragspatronen, die noodzakelijk zijn om zonder al te veel misverstanden en wrijvingen met elkaar te kunnen omgaan. Het gedrag verkrijgt er een zekere mate van voorspelbaarheid door. Normen zijn vaak cultuurgebonden door duurzame gedragsregels en opvattingen over hoe men zich wel en niet dient te gedragen. Binnen bepaalde groeperingen zijn normen tot op zekere hoogte bindend voor de leden. Het is goed erop te wijzen dat normen doorgaans niet alleen grenzen stellen aan uiterlijk waarneembare gedragingen (norm als regel voor gedrag), maar dat normen ook betrekking hebben op cognitieve elementen; gevoelens, gedachten en neigingen kunnen voorwerp van norm zijn. Normen zijn niet alleen aan plaats maar ook aan tijd gebonden. Zo is het bijvoorbeeld thans in Zuid-Limburg de norm dat men zijn neus in een zakdoek snuit en niet meer zoals vroeger in de mouw van een jas of hemd. Normen worden strikt nageleefd bij bepaalde protocollen en godsdienstige ceremoniën; rekkelijker zijn thans de normen ten aanzien van individuele personen; hoogleraren treft men in de onderwijspraktijk niet alleen in driedelig grijs aan maar ook in slobbertrui en spijkerbroek. Philipsen (1989) heeft een ideaaltypische omschrijving van het begrip norm gegeven en onderscheidt daarbij acht kenmerken:

a. De gedragsregel houdt een feitelijke verwachting in dat men in overeenkomstige situaties eender zal handelen;

b. Uitblijven van het gedrag wordt beoordeeld volgens criteria als ongepast, onbehoorlijk, onbetamelijk of wat zwakker, ongebruikelijk; 
c. Gedrag overeenkomstig of in afwijking van de norm zal sociale sancties oproepen, goedkeurende respectievelijk afkeurende reacties van relevante anderen;

d. Men voldoet aan de verwachtingen uit zichzelf, wellicht niet altijd uit volle overtuiging, misschien alleen met het oog op de sancties, maar er is geen sprake van dwang in de fysieke en/of juridische betekenis van het woord;

e. Het betreft geen geformaliseerde en gestandaardiseerde voorschriften; er is altijd ruimte voor individuele toepassing;

g. Normen worden gedeeld door categorieën of groepen mensen, inclusief de betrokkenen; ze zijn niet individueel van aard;

$h$. Normen staan niet op zichzelf; ze hangen samen met andere normen en kunnen inhoudelijk begrepen worden door ze in verband te brengen met waarden of ze te verklaren uit sociale functies of historische processen (pag. 121).

Normen en waarden worden vaak in een adem genoemd; dat zou er op kunnen duiden dat ze onderling aan elkaar gerelateerd zijn. Voor Oskamp (1977) is een waarde een belangrijk levensdoel of gedragsstandaard. In deze betekenis kunnen geld, macht, naastenliefde en democratie als waarde opgevat worden. Waarden kunnen vanuit een verschillende invalshoek betekenis hebben: in economische termen drukt men waarde uit in baar geld terwijl bijvoorbeeld een religieuze waarde betrekking heeft op een zekere mate van naastenliefde. Vanuit de optiek van de sociale wetenschappen zijn waarden maatstaven met behulp waarvan men het eigen gedrag en dat van anderen beoordeelt. Philipsen (1989) spreekt van denkbeelden over "zaken" die voor goed en wenselijk worden gehouden. Anders dan een norm specificeert een waarde dus niet een concrete handeling of gedragsalternatief, maar veeleer een abstract uitgangspunt voor het gedrag. Om met Philipsen te spreken, een waarde wordt opgevat als een richtlijn voor het gedrag op grond waarvan normen geïnterpreteerd kunnen worden. Het begrip, aldus Philipsen (1989), als volgt beschreven worden. "Waarden zijn: a. denkbeelden over zaken (soms "deugden"), b. die voor goed en wenselijk worden gehouden, c. volgens een verscheidenheid van criteria voor goedheid, $d$. die deel uitmaken van de cultuur van de samenleving, e. alleen begrepen kunnen worden in samenhang met andere normen en waarden alsook andere elementen van de cultuur" (pag. 130). 
Sociale invloed is een belangrijke factor die in voorlichtingskundige interventies lang onderbelicht is gebleven. De directe omgeving oefent bewust of onbewust invloed uit op het feitelijke gedrag van het individu. Sociale normen zijn dus persoonlijke inschattingen over wat de sociale omgeving van de persoon verwacht. Sociale normen zijn altijd aanwezig, omdat een individu niet in een vacuüm kan leven. De inschatting van sociale normen kan per individu verschillen omdat hij in zijn doen en laten kan refereren aan verschillende groepen (bijvoorbeeld de thuissituatie, zijn werkomgeving, zijn lidmaatschap van een politieke partij of gezelligheidsvereniging). De omgeving van een persoon en de daarin heersende normen en waarden kunnen een remmende of stimulerende invloed uitoefenen op de zienswijze en de menings- en besluitsvorming, ten aanzien van bepaald gedrag.

Sociale invloed manifesteert zich in twee vormen, namelijk directe en indirecte sociale invloed. Directe sociale invloed heeft betrekking op de verwachtingen van anderen hoe een persoon zich dient te gedragen. Men zou kunnen zeggen dat het gedrag van de persoon in kwestie door anderen wordt gesanctioneerd. Indirecte sociale invloed is subtieler van aard. De persoon neemt middels observatie (modelling) gedrag en gedachten van anderen over zonder dat er enige vorm van dwang wordt uitgeoefend. Het denken (opvattingen ten aanzien van normen en waarden) en doen (gedrag) van de sociale omgeving wordt geinternaliseerd door de persoon. Bij internalisatie is de eigen attitude ten aanzien van het gedrag en de mening van de sociale omgeving convergent. Voor gerichte beïnvloedingspogingen is het van belang om de sociale invloed zo veel mogelijk te specificeren.

Cognities hebben betrekking op het resultaat van de wijze waarop mensen informatie vergaren, verwerken en vastleggen in het geheugen. Gegeven het feit dat mensen fysiek en intellectueel genoodzaakt worden om informatie selectief op te nemen, dient men er van uit te gaan dat de meeste mensen beschikken over een beperkte kennis (onwetendheden, onduidelijkheden en onnauwkeurigheden). Met dit gegeven lijkt niets aan de hand - men kan en hoeft per slot van rekening niet alles te weten - maar het wordt problematischer wanneer we ons realiseren dat mensen met beperkte beschikbare kennis de omringende wereld waarnemen, interpreteren en beoordelen. De overgedragen kennis wordt vanuit een bepaalde optiek beoordeeld. De informatie die we ontvangen, wordt nog eens ver- 
tekend en gekleurd - soms zelfs verminkt - door persoonlijke voorkeuren, bijvoorbeeld vanuit een bepaalde religieuze overtuiging of vanuit een politieke stellingname. Dit proces van waarneming en betekenisvervorming wordt selectieve perceptie genoemd. Naast selectieve perceptie zijn voor voorlichting nog twee selectiemechanismen van belang namelijk, "selective exposure" (selectieve blootstelling) en "selective retention" (selectief onthouden en vergeten). Stappers et al. (1990) stelt dat selectieve blootstelling de belangrijkste verschijningsvorm van selectiviteit is in het massacommunicatie-onderzoek. In hoofdstuk 7 komen we hierop terug. Voor effectieve voorlichting is het van groot belang om na te gaan of mensen een gebrek aan kennis of verkeerde kennis hebben. Met een eenvoudige vragenlijst is dit doorgaans makkelijk te meten.

Kennisvermeerdering $\mathrm{kan}$ in uitzonderlijke gevallen leiden tot gedragsverandering. Dit is echter geenszins absoluut. Kennis wordt wel als basis beschouwd voor een eventuele verandering (Jarlais en Freedman, 1988; Kegeles et al., 1988), maar er zijn diverse andere factoren in het geding die een sterkere invloed hebben op een definitieve verandering. Zo stelt Bandura (1986) dat de eigen effectiviteit, dat wil zeggen de inschatting die een persoon maakt van zijn mogelijkheden om een bepaald gedrag te vertonen, een belangrijke voorspeller is van (preventief) gedrag. Kok et al. (1990) stellen dat inzicht in de rol van eigen-effectiviteit vooral van belang is bij het analyseren van het achterwege blijven van gewenst gedrag. Eigen-effectiviteit is gebaseerd op vroegere ervaringen met het gedrag, met name attributies voor succes of falen.

Naast de cognities, attitudes en sociale invloed, die overigens niet volledig onafhankelijk van elkaar zijn, moet men zich nog rekenschap geven van de risicoperceptie. Dit laatste begrip staat centraal in de protectie-motivatie theorie van R.W. Rogers (1983). Volgens deze theorie wordt gedragsverandering bepaald door een inschatting (perceptie van het risico) ten aanzien van de ernst van een bepaalde dreiging, de vermeende kwetsbaarheid, de effectiviteit van bepaalde gedragingen om het gevaar te vermijden en de mate waarin men denkt in staat te zijn om het gewenste gedrag te bereiken. Deze vier factoren bepalen de voorspellende waarde om bepaald gedrag te vertonen. Tot de gedragsdeterminanten worden ook weleens behoeften gerekend. De meest bekende drogreden in de praktijk van de voorlichting is dat de effectiviteit toeneemt naarmate de voorlichting 
weet aan te sluiten bij de behoeften. Dat is een waarheid als een koe, maar wel een bedrieglijke als we die behoeften niet kunnen operationaliseren. Het begrip behoefte is nauwelijks hanteerbaar als we verzuimen aan te geven op welk object die behoefte zich richt. In dit kader zouden we kunnen spreken van de behoefte aan informatie, die kan omschreven worden als het geheel van manifeste of latente verwachtingen, wensen en belevingen die binnen de voor te lichten populatie leven ten aanzien van informatievergaring/verschaffing. Behoeften kunnen evenwel ook betrekking hebben op de doelstelling die we willen verwezenlijken. Stel dat de voorlichtingsboodschap belooft dat het opvolgen van bepaalde adviezen er toe leidt dat men zich 's morgensvroeg fit en energiek voelt, dan is de uitkomst van die belofte de behoefte waaraan men refereert. De behoefte is dan het verschil tussen de ongewenste oude situatie en de gewenste nieuwe situatie. Een voorbeeld: katerig, traag en suf 's morgens op gang komen versus fris, vrolijk en kwiek de hand aan de ploeg slaan! Het zal duidelijk zijn dat de laatst bedoelde behoefte zeker bij intentionele voorlichting een belangrijke rol speelt: naarmate de voorlichting meer aansluit bij de behoefte, die zich doet gevoelen bij de uitkomst van het gewenste gedrag, zall het effect van de interventie toenemen.

Tot slot van deze paragraaf wordt nog gewezen op mogelijke barrières, die de uitvoering van het gewenste gedrag kunnen dwarsbomen. Het uitvoeren van gedrag is in sterke mate afhankelijk van de vraag of er überhaupt mogelijkheden zijn om het gewenste gedrag uit te voeren. Het kan bijvoorbeeld gebeuren dat het aanbevolen gedrag is om bepaalde medicijnen te slikken maar als die preparaten nergens verkrijgbaar zijn, is het gewenste gedrag moeilijk uitvoerbaar. Tot de mogelijkheden tot het uitvoeren van gedrag rekenen we ook factoren als tijd en geld. De mogelijkheden worden in feite begrensd door de moeite die men zich moet getroosten om de aanwijzingen op te volgen. In de regel kan men stellen: hoe minder moeite het kost, des te makkelijker worden de adviezen opgevolgd.

Steeds meer voorlichters raken overtuigd van het nut van een grondige determinantenanalyse. De laatste jaren wordt veel aandacht geschonken aan methoden om het uitvoeren van determinantenanalyses toegankelijker te maken voor de praktijk van de voorlichting (Krueger, 1988). 


\section{Ad 3 gedragsbeinvloeding}

Alvorens tot beinvloeding overgegaan kan worden, moeten aan het eind van de determinantenanalyse twee belangrijke beslissingen worden genomen, namelij $\mathrm{k}$ over:

1. de relatieve belangrijkheid van de determinant(en) die het probleem veroorzaakt (veroorzaken);

2. de relatieve veranderbaarheid van de determinant(en).

Bij de eerste beslissing moet men overwegen in welke omvang en frequentie de determinant optreedt en in welke mate deze zich verhoudt tot andere mogelijke determinanten. Voorts wordt zorgvuldig bekeken hoe sterk de relatie is met het gezondheidsprobleem en hoe noodzakelijk het is om de invloed van deze determinanten te reduceren. Het is wel denkbaar dat op grond van deze afweging meer determinanten voor beïnloeding in aanmerking komen. De beslissing die genomen moet worden, kan tot gevolg hebben dat men bepaalde determinanten ongemoeid laat of dat men prioriteiten gaat aanbrengen indien meerdere determinanten voor beïnloeding in aanmerking komen. In dit laatste geval moet men bedenken dat dit consequenties kan hebben ten aanzien van een mogelijke verscheidenheid en hiërarchie aan doelstellingen.

Bij de tweede beslissing gaat het om de vraag of de determinanten met gedragsbeïnvloedingstechnieken veranderd kunnen worden in de gewenste richting. Om een afgewogen beslissing te kunnen nemen, dient men goed op de hoogte te zijn van de reikwijdte en het functionele gebruik van de middelen. Het gaat hier dus in feite om de vraag hoe krachtig het medium of de methodiek moet zijn om de verandering te bewerkstelligen. De keuze voor een bepaald medium zal afhangen van het zogenaamd communicatievermogen van het medium. Het communicatievermogen wordt onder andere bepaald door het karakter, het bereik, de soort overdracht, de attentiewaarde etc.. Het zal duidelijk zijn dat voor gedragsverandering meer energie, tijd en vernuft nodig is dan voor het vermeerderen van kennis.

De vragen naar de relatieve veranderbaarheid en relatieve belangrijkheid bestrijken in wezen de toets der haalbaarheid. Dit is de eerste stap in het ontwikkelen van een strategie: het effectief en doelmatig aanwenden van methoden en technieken in het licht van de geformuleerde doelstelling(en). De effectiviteit van een interventie is de mate waarin vooraf geformuleerde doelstellingen worden gerealiseerd. Al 
naar gelang de aard en complexiteit van het probleem kunnen we doelstellingen formuleren op verschillende niveau's. Dit betekent dat we een hiërarchie in doelstellingen moeten aanbrengen.

Vanaf het moment dat de beslissing is genomen media in te zetten om het gesignaleerde probleem te beteugelen, is "Het werkplan voor massamediale voorlichting" van Van Woerkum (1982) goed bruikbaar. Het werkplan heeft als uitgangspunten:

1. publieksgerichtheid: het segmenteren van homogene publieksgroepen en afstemming van de boodschap op het geselecteerde publiek;

2. planmatigheid: de methode doorloopt een zevental fasen, namelijk voorbereiding, ontwerp, productie, eerste revisie, tweede revisie, contact en evaluatie;

3. situatiegerichtheid: het werkplan is zodanig geconstrueerd dat het zowel voor afzonderlijke media als multimediaal toepasbaar is in verschillende situaties;

4. aangepaste methodologie, hetgeen betekent: toepassingsgericht onderzoek bij ontvangers, de boodschap en bij de effectmeting. De kern van de aangepaste methodologie is de bruikbaarheid voor de praktijk.

\section{ad 4 evaluatie}

Evaluatie-onderzoek geeft antwoord op de vraag of en waarom een interventie wel of geen effect heeft teweeggebracht. Ook is het een goed instrument om verantwoording af te leggen over de uitgevoerde activiteiten en de besteding van de gelden. Tevens geldt dat men de kwaliteit van toekomstige interventies kan verbeteren: immers, evaluatie is in wezen het vergelijken van het resultaat van de interventie met het vooraf geformuleerde doel. Het geeft inzicht in die factoren of mechanismen die het gewenste effect begunstigen of belemmeren. Evaluatie kan aldus opgevat worden als sturingsmechanisme, indien men tijdens de interventie momenten inbouwt om de tussenstand op te nemen. Het komt nog maar al te vaak voor dat de evaluatie uit de losse pols gebeurt, waardoor men niet met zekerheid kan zeggen of de doelstellingen inderdaad verwezenlijkt zijn. Het streven moet dan ook gericht zijn op het objectiveren van de evaluatie, dat wil zeggen dat aan de methodologische criteria van reproduceerbaarheid en validiteit moet worden voldaan. Een evaluatie-onderzoek kan de toets 
der validiteit doorstaan, als het gemeten effect uitsluitend aan de interventie en niet aan andere factoren kan worden toegeschreven.

Er worden twee vormen van evaluatie onderscheiden, namelijk proces-evaluatie en effect-evaluatie. Proces-evaluatie probeert zo nauwkeurig mogelijk in kaart te brengen wat er feitelijk gebeurd is bij de voorbereiding, ontwikkeling en uitvoering van de interventie. Deze feitelijkheden worden getoetst aan vooraf opgestelde planningscriteria. In de praktijk ligt de nadruk meestal op de middelenallocatie, dat wil zeggen de aanwending van hulpbronnen (tijd, personeel, financiën, media, materialen) en op de beoordeling van deelnamecijfers en andere geregistreerde gegevens (bijvoorbeeld de participatiegraad).

Bij effect-evaluatie gaat het om de vraag of de interventie voldaan heeft aan de doelstelling. De kwaliteit van de effect-evaluatie valt en staat met het ontwerpen van het onderzoeksdesign. Bij effect-evaluatie moet er altijd een meting van de beginsituatie plaatsvinden (de zogenaamde nulmeting) bij zowel degenen die object van de interventie zijn (de experimentele groep) als bij een groep die niet blootgesteld is aan de interventie (de controlegroep). Bij beide groepen dient een nameting plaats te vinden om na te gaan of de eventuele effecten ook daadwerkelijk aan de interventie kunnen worden toegeschreven. Bij het opzetten van een evaluatie-onderzoek hoort een experimenteel design (zoals boven omschreven) het hoogste doel te zijn, dat wil zeggen een design met een voormeting en een nameting en een equivalente controlegroep.

In het voorafgaande is benadrukt dat men in de voorbereiding van een interventie steeds systematisch te werk moet gaan; idem dito geldt dit voor de evaluatie. Dit impliceert dat stapsgewijs moet worden nagegaan of de respectievelijke (sub)doelen in het proces gerealiseerd zijn. In figuur 2.3 komt de planning en evaluatie duidelijk naar voren. 


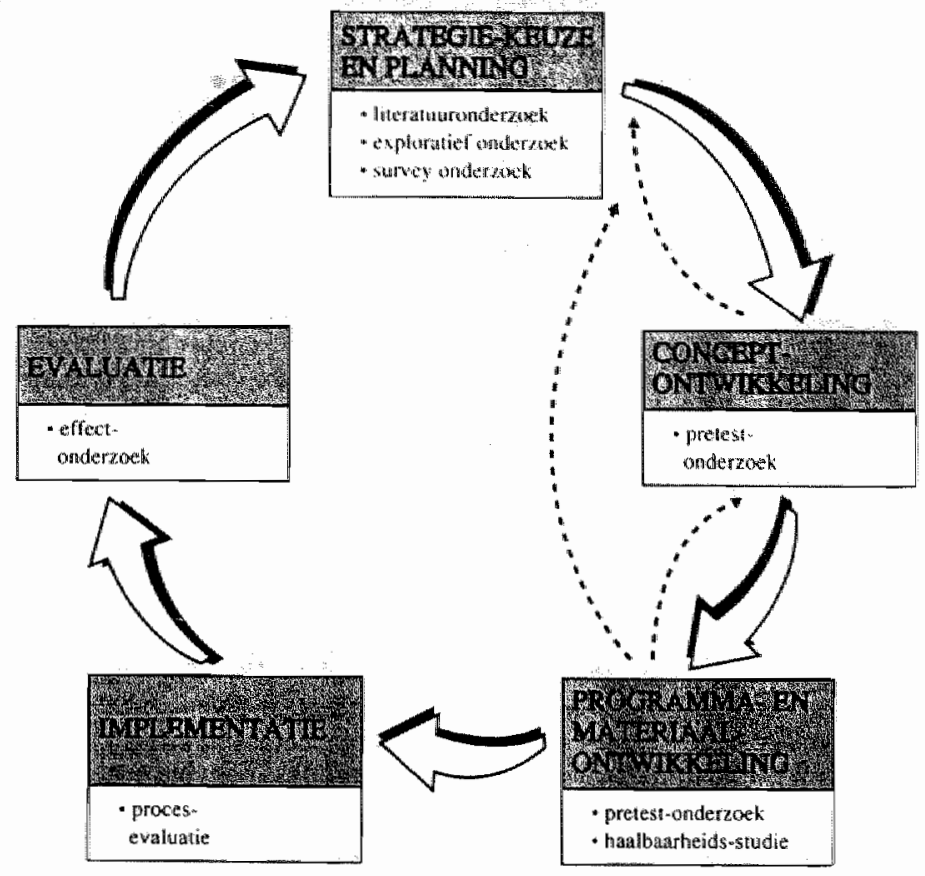

Figuur 2.3 Onderzoek binnen de verschillende stadia van een interventie.

Bron: Kanters en Wieberdink, 1990, pag. 15.

\subsection{De doelgerichtheid van intentionele voorlichting}

Het formuleren van doelstellingen kan betrekking hebben op een heel scala van activiteiten: informeren, stimuleren, bewustmaken, verbeteren, mobiliseren, adviseren, veranderen etc... Doelformulering is geen sinecure: twee essentiële elementen worden maar al te gemakkelijk over het hoofd gezien. Ten eerste wordt meestal de aandacht gericht op de finale doelen, dat wil zeggen de effecten die men wenst te bereiken na afloop van de interventie. Echter, men moet bedenken dat een veranderingsproces verloopt van een onbevredigende beginsituatie (probleem) naar het bewerkstelligen van een gewenste situatie 
(de oplossing van het probleem). Dit proces verloopt stapsgewijs, dat wil zeggen er moeten verschillende fasen doorlopen worden wil men tot een uiteindelijk resultaat geraken.

Voor de voorlichtingsstrategie heeft dit tot gevolg dat men per fase subdoelen moet formuleren die op consistente wijze leiden tot het finale doel. Het structureren van de doelstellingen brengt meestal specificatie van de doelen met zich mee op korte, middellange en lange termijn. Kok en Sandfort (1990) hanteren als belangrijk voorlichtingsprincipe het gegeven dat naast voordelen op de lange termijn vooral gewezen moet worden op de voordelen op de korte termijn. Dit principe heeft als consequentie dat men zich goed moet beraden over welke positieve aspecten van het gewenste gedrag per subdoelstelling geformuleerd kunnen worden.

Een tweede cruciale factor bij de doelformulering is het abstractieniveau. Bij het formuleren van doelen gaat men vaak in de fout door doelen te kiezen op een te hoog abstractieniveau. Het is zinvoller om geen abstracte formuleringen te gebruiken, maar de doelstellingen te vertalen in termen van het gewenste, concrete resultaat. Dus geen formulering in de trant van "voorlichting geven om blessures te voorkomen", maar concreet meetbare doelen, bijvoorbeeld een reductie van 5\% van het aantal knieblessures onder voetballers van 15 tot en met 20 jaar binnen een periode van 2 jaar. Concreet meetbare doelen mogen natuurlijk niet zo maar "uit de losse pols" gesteld worden; anders krijgen we een schijnexactheid waarbij een specifiek getal eigenlijk een volledige slag in de lucht is. De keuze voor een concreet meetbaar doel dient grondig beargumenteeerd te worden.

Rossi (1979) noemt enkele aspecten die bij de operationalisatie van doelen van grote betekenis zijn.

1. De doelstelling(en) moet(en) exact aangeven op welke groep de interventie gericht is. Dit betekent een nauwkeurige segmentatie van de doelgroep.

2. De doelstelling(en) moet(en) aangeven op welk niveau de doelstelling gerealiseerd dient te worden. Wil men met de voorlichting kennis vermeerderen, attitude wijzigen of gedragsveranderingen bereiken?

3. In de doelstelling(en) moet een tijdslimiet vervat zijn. Een afbakening in een termijn geeft niet alleen inzicht in het verloop van het voorlichtingsproces, maar biedt bovenal de gelegenheid om tijdig de interventie bij te sturen of om ongewenste neveneffecten te voorkomen. 
4. De doelstelling(en) moet(en) consistent zijn: bij de formulering van de doelstelling(en) moet men er op toezien dat ze in elkaars verlengde liggen en elkaar ondersteunen. Zij mogen in ieder geval niet conflicterend zijn. Indien men doelstellingen wil verwezenlijken op de onderscheiden niveau's dient men ervan uit te gaan dat de doelstellingen cumulatief van aard zijn.

5. Bij het formuleren van de doelstelling(en) zal men steeds de advocaat van de duivel moeten spelen. Dat wil zeggen: men moet kritisch nagaan wat mogelijkerwijze het effect zou zijn van foutieve interpretatie. Men moet zich dus rekenschap geven van niet bedoelde neveneffecten.

6. De doelstelling(en) moet(en) realistisch en haalbaar zijn. Kritische zelfreflectie is hier op zijn plaats.

Als aanvulling op bovengenoemde aspecten van Rossi willen we nog wijzen op de verschillen tussen een interventiedoel en een communicatiedoel. Een interventiedoel is gericht op de oplossing van het gesignaleerde probleem. Het interventiedoel geeft aan naar welke effecten bij een bepaalde populatie gestreefd wordt en omschrijft de verwachte resultaten in termen van verifieerbare grootheden (indicatoren als tijd, omvang, etc.). Het interventiedoel dient geoperationaliseerd te worden in subdoelen, die weergegeven worden in gedragstermen. Figuur 2.4 laat aan de hand van een voorbeeld over skiblessures het traject zien van probleem naar communicatiedoel.

Het communicatiedoel heeft betrekking op de inhoud van de boodschap en geeft aan welke handelingen van de doelpopulatie verwacht worden. Een communicatiedoel kan de toets der kritiek doorstaan als voldaan is aan de volgende criteria:

1. specificiteit, dat wil zeggen men dient specifiek aan te geven welke kennis, attitude of gedrag men wenst te veranderen;

2. handelingsgerichtheid, dat wil zeggen de boodschap geeft aan welke handelingen van de persoon verwacht worden en geeft aan op welke wijze de handelingen verricht dienen te worden;

3. betrokkenheid, dat wil zeggen de boodschap speelt in op de belangen, interesses en leefwereld van de ontvangers en draagt bij aan de ontvankelijkheid en biedt mogelijkheden tot identificatie;

4. realisme dat wil zeggen dat de handelingen betrekkelijk eenvoudig zijn uit te voeren en verenigbaar zijn met bestaande normen en waarden; 
5. waarneembaarheid d.w.z dat de boodschap in concreto aangeeft wat mensen zich bij de verandering moeten voorstellen.

$\frac{\text { Problecm }}{t}$

Gezondheidsprobleem

1

$\downarrow$

GVO-probleem
$\downarrow$
$\downarrow$

Problemstelling

$\downarrow$

Vraastelling van

dit onderzoek

$\downarrow$

Interventiedoel

I

I

I

I

I

$\downarrow$

Communicatiedoell
Het behandelen en verzorgen van ski-blessures heef nadelige gevolgen voor de samenleving

Het beoefemen van de akisport heeft madelige gevolgen voor het welzijn van de individuele sporter

Het gedras van de sporter heeft een positieve dan wel negatieve invloed op het voorkomen van blessures

Kan het gedrag van de skiễr door middel van voorlichting beirvloed worden, zodat een roductic van blessures bowedistelligd wordt?

Op welke wijze ban cen gezondheidseducatieve interventic- bijdragen an het voorkomen van skiblessures ?

Voorlichting moet leiden tot:

- toename van kennis over de te nemen veiligheidsmsatregelen tu.v. de vitrusting

- bewtustwording van de gevaren en cen positieve houding tev. vellightid

- scceptatie van de veliligheidsadviezen

- positieve intentie ter.v. het gebruik van de uitrusting

- bet laten afstellen van de sbibindingen door de valoman met behulp van cen testappanat

Figut 2.4 Van probleem naar communicatiedoel. 
Rogers $(1971,1983)$ stelt dat wanneer het om ingrijpende veranderingen gaat, men de ontvanger in de gelegenheid moet stellen om te experimenteren met het gewenste gedrag zonder dat dit verplichtingen jegens hemzelf of derden met zich meebrengt (zie ook het integratiemodel van Flay in paragraaf 5.6).

Het is opmerkelijk dat vele voorlichtingscampagnes mank gaan aan duidelijke communicatiedoelen. Zo staan er vandaag de dag borden langs de Nederlandse snelwegen met als tekst: "Hard rijden kost teveel" en wordt in een nationale campagne ter voorkoming van sportblessures de slogan: "Blessures, maak er geen sport van!" gebruikt. Het moge duidelijk zijn dat dit, voorlichtingskundig gezien, tamelijk grote blunders zijn.

\subsection{De planmatigheid van intentionele voorlichting}

In het algemeen kan men stellen dat het succes van een voorlichtingsactiviteit afhangt van de mate waarin de voorlichter er in slaagt mensen te motiveren tot ander (gezonder of veiliger) gedrag. Motivering moet hier worden opgevat in de zin van mensen in de gelegenheid stellen om zelf het gewenste gedrag te kiezen. Mensen prefereren in de regel dat gedrag dat in hun perceptie het meest belonend is. Mensen die zelf heel bewust kiezen voor ander gedrag zullen dit gedrag ook beter en langduriger uitvoeren. Het zal weinig betoog behoeven dat het bij voorlichting niet de bedoeling is dat het gewenste gedrag slechts incidenteel vertoond wordt. Het gaat erom dat het gewenste gedrag ingebed raakt in het dagelijks handelen. Vandaar ook dat het streven meer gericht is op gedragsbehoud dan op gedragsverandering. De nadruk op gedragsbehoud neemt natuurlijk niet weg dat vooraleerst de krachten gebundeld moeten worden om een verandering van gedrag te bewerkstelligen.

Om te kunnen begrijpen waarom mensen zich gedragen zoals ze zich gedragen, zullen we inzicht moeten hebben in de motivatie van gedrag. Aangenomen wordt dat er twee motivationele principes zijn die het gedrag van mensen sturen, namelijk het streven naar cognitieve ordening (het ordeningsprincipe) en het streven naar het verkrijgen van zo positief mogelijke opbrengsten (het beloningsprincipe) (Veen en Wilke, 1984). 
Met het ordeningsprincipe wordt bedoeld dat mensen het geheel van indrukken waarmee ze geconfronteerd worden, overzichtelijk willen structureren. Cognitieve ordening betreft het verwerkingsproces van informatie om de ongestructureerde werkelijkheid te beheersen. Het principe van de beloningsbenadrukking heeft betrekking op de mate waarin gedrag door de sociale omgeving gesanctioneerd of bekrachtigd wordt. Indien gedrag door de sociale omgeving (vrienden, bekenden, collega's etc.) positief gewaardeerd wordt, zal dat gedrag vaker vertoond worden. Tevens geldt dat negatieve sanctionering zal leiden tot gedrag dat minder vaak en minder graag vertoond wordt.

Aansluitend bij de beloningsbenadrukking wijzen we erop dat de ontvanger het advies of het gewenste gedrag eerder zal opvolgen als daaraan een gratificatie verbonden is. Als iemand zich de moeite getroost zich conform de boodschap te gedragen dan zou daar ook een beloning tegenover moeten staan. Deze beloning hoeft natuurlijk niet in klinkende munt uitgedrukt te worden. De beloning kan bestaan uit het prettig vinden om bewondering en waardering te oogsten, of een beter resultaat verwerven. De inhoud van de boodschap moet effectief zijn en op waarheid berusten in die zin dat opvolging van de boodschap ook inderdaad voldoet aan de serieuze verwachtingen die men heeft opgeroepen. Als de boodschap belooft dat een bepaald soort dieet tot gewichtsverlies leidt, dient men zich er als voorlichter van tevoren van te vergewissen dat dit vermageringsdieet ook daadwerkelijk effectief is ten aanzien van de reductie van gewicht. Door de effectiviteit van de boodschap moeten mensen overtuigd raken dat het nieuwe gedrag te prefereren is boven het ongewenste oude. In die gevallen waarin klaarblijkelijk bij de doelgroep een misverstand bestaat ten aanzien van het op te volgen advies (inhoud) van de boodschap, is het zaak ruim aandacht te besteden aan het gebruik en de ordening van argumenten.

In het voorafgaande zijn essentiële factoren besproken, die aangeven dat intentionele voorlichting een complex proces is.

Het veranderen van attitude en gedrag is niet zo eenvoudig als het op het eerste gezicht lijkt. Gedrag wortelt namelijk diep in cultuurpatronen, opvoedingssystemen, waarden en groepsnormen. Wil men gedragsbehoud realiseren door middel van voorlichting dan is een gefaseerde aanpak noodzakelijk. Deze fasering dient zorgvuldig overwogen te worden in die zin dat iedere fase een afweging behoeft van doelstelling, methoden, media, allocatie van menskracht, etc.. De 
fasering van het voorlichtingsproces kan het beste verduidelijkt worden aan de hand van de communicatiematrix van McGuire.

\begin{tabular}{|c|c|c|c|c|}
\hline \multirow{2}{*}{$\begin{array}{l}\text { INPUT: Independent } \\
\text { (Communication) } \\
\text { Variables } \\
\text { OUTPUT: } \\
\text { Dependent } \\
\text { Variables. } \\
\text { (Response Steps } \\
\text { Mediating Persuasion) }\end{array}$} & SOURCE & MESSAGE & CHANNELL & RECENER \\
\hline & 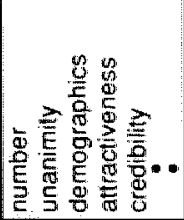 & 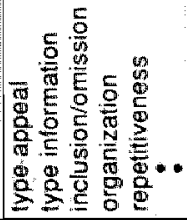 & 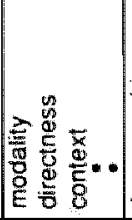 & 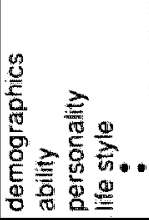 \\
\hline $\begin{array}{l}\text { 1. Exposure to the } \\
\text { communication }\end{array}$ & & & & \\
\hline 2. Attending to it & & & & \\
\hline $\begin{array}{l}\text { 3. Liking, becoming } \\
\text { interested in it }\end{array}$ & & & & \\
\hline $\begin{array}{l}\text { 4. Comprehending it } \\
\text { (learning what) }\end{array}$ & & & & \\
\hline $\begin{array}{l}\text { 5. Skill acquisition } \\
\text { (learning how) }\end{array}$ & & & & \\
\hline $\begin{array}{l}\text { 6. Yielding to it } \\
\text { (attitude change) }\end{array}$ & & & & \\
\hline $\begin{array}{l}\text { 7. Memory storage of } \\
\text { content and joir } \\
\text { agreement }\end{array}$ & & & & \\
\hline $\begin{array}{l}\text { 8. Information } \\
\text { search and } \\
\text { retrieval }\end{array}$ & 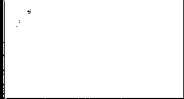 & & & \\
\hline $\begin{array}{l}\text { 9. Deciding on basis } \\
\text { of retriewal }\end{array}$ & & & & \\
\hline $\begin{array}{l}\text { 10. Behaving in accord } \\
\text { with decision }\end{array}$ & & & & \\
\hline $\begin{array}{l}\text { 11. Reinforcement of } \\
\text { desired acts }\end{array}$ & & & & \\
\hline $\begin{array}{l}\text { 12. Post behavioral } \\
\text { consolidalling }\end{array}$ & & & & \\
\hline
\end{tabular}

Figuur 2.5 De matrix van McGuire.

Bron: McGuire, 1989, pag. 45. 
Fase 1

Blootstelling

Fase 2

Aandacht en

interesse

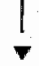

Fase 3

Begrip

Fase 4

Toetsen van

nieuwe

informatie

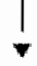

Fase 5

Attitude-

vorming
Voorlichting kan slechts effect hebben wanneer de ontvanger aan informatie blootgesteld wordt; bw. folders die niet ontvangen worden, kunnen niet gelezen worden. Wil het informatieproces in gang gezet kunnen worden, dan is ontvangst van de boodschap een voorwaarde.

De informatie moet doordringen tot de ontvanger: hij of zij moet de informatie opnemen (lezen, beluisteren). De informatie moet de interesse van de ontvanger opwekken, op een zodanige wijjze dat deze zilch nader gaat verdiepen in de informatie. De mate van aandacht is bepalend voor de motivatie om de informatie op te slaan.

Voorlichting kan slechts effect hebben als de ontvanger de strekking van het bericht begrijpt. Het begrijpen van de boodschap komt o.a. tot uiting in een toename van nieuwe kennis of een bevestiging van reeds elders verworven informatie. De informatie wordt door de ontvanger geordend.

Als de informatie verwerkt en begrepen is zal men deze toetsen aan reeds verworven informatie. Men zal de waarde van de informatie inschatten op de consequenties voor zijn persoon en afwegen of er aan de nieuwe informatie gratificaties verbonden zijn.

De afweging van voor- en nadelen uit stap 4 zou kunnen resulteren in een attitude-verandering. Positieve opvattingen over het bericht gedurende de eerste vier fasen, zullen in de regel leiden tot een versterking van de attitude. Een attitude-verandering zal voorspoediger verlopen naarmate men in de directe omgeving het gewenste gedrag meer als vanzelfsprekend of gewoon beschouwt. 
Fase 6

Aanvaarding<smiles></smiles>

Fase 7

Opslaan en actualiseren<smiles>[CH]1[CH]CC1</smiles>

Fase 8

Intentie

1

Fase 9

Gedrag

1

Fase 10

Gedragsbehoud
Bij een positieve attitude ten aanzien van het gewenste gedrag zal men proberen meer inzicht te verwerven in de consequenties van de verandering. Hierbij wordt ondermeer nagegaan of men voldoende vaardigheden, mogelijkheden of competenties bezit om het gedrag uit te voeren. Ook zullen de mogelijkheden tot zelf-controle worden nagegaan.

Men zal instemmen met informatie en de consequenties daarvan aanvaarden wanneer men zijn voornemens getoetst heeft aan mensen uit de directe omgeving of belangrijke anderen. Indien de sociale omgeving positief reageert, zal men eerder geneigd zijn om de voornemens ten uitvoer te brengen.

De intentie om het gewenste gedrag ten uitvoer te brengen kan nog gedwarsboomd worden door een aantal praktische barrières. Die kunnen er ook de oorzaak van zijn dat de opvolging van het gewenste gedrag wordt uitgesteld of niet geheel conform de adviezen vorm krijgt.

Het gedrag wordt conform de adviezen opgevolgd. Eenmalige, kortdurende gedragsverandering is niet zinvol. Het streven moet gericht zijn op gedragsbehoud.

Positieve ervaringen en feedback als extrin* sieke beloning van het gedrag leiden tot gedragsbehoud.

Figuur 2.6 Outputvariabelen van het communicatieproces.

Deze matrix, bestaande uit 12 outputvariabelen aan de verticalle zijde en 4 inputvariabelen aan de horizontale zijde, biedt een helder overzicht van mogelijke relaties tussen onafhankelijke en afharkelijke 
variabelen in het communicatieproces. De onafhankelijke variabelen (bron, boodschap, ontvanger, kanaal) kunnen gemanipuleerd worden bij de samenstelling van het communicatiedoel. De outputvariabelen geven stapsgewijs aan in hoeverre communicatiedoelen successievelijk verwezenlijkt zijn. Door meting kan de aard en omvang van de verandering in de opeenvolgende fasen worden vastgesteld. Het onderstaande model is ontleend aan McGuire en aan de theorie van beredeneerd gedrag van Fishbein en Ajzen (1980).

Dit fasenmodel is niet zaligmakend. Het is te beschouwen als een voorbeeld van hoe gedragsverandering middels voorlichting tot stand kan worden gebracht. In hoofdstuk 5 wordt dieper op deze materie ingegaan en zal duidelijk worden dat het ontwikkelen van een model voor gedragsverandering complexer is dan bovenstaand model doet vermoeden.

\subsection{Slotbeschouwing}

Gezondheidsvoorlichting en -opvoeding bestrijkt een brede waaier van activiteiten, kent vele doelstellingen, richt zich tot verschillende doelpopulaties en wordt uitgevoerd op verschillend niveau. Dit heteromorfe beeld van GVO bemoeilijkt een gedetailleerde beschrijving van de huidige stand van zaken anno 1990. De samenhang in de activiteiten, die als GVO gelabeld worden, kan gegeneraliseerd worden tot instrument in de zorg voor gezondheid. Jonkers et al. (1988) vatten de plaats van GVO in het gezondheidsbeleid als volgt samen: "GVO is een instrument van gezondheidsbeleid, naast voorzieningen, maatregelen en wetgeving; GVO speelt in alle sectoren van de gezondheidszorg; GVO als instrument van gezondheidsbeleid, kan via facetbeleid in andere maatschappelijke sectoren geplaatst worden" (pag. 21). Kenmerkend voor adequaat beleid is de noodzaak om de voorhanden zijnde instrumenten evenwichtig tot ontwikkeling te brengen en ze optimaal te benutten. In dit werk beschrijven we GVO als instrument van preventie en beperken ons tot de optiek van publieksgerichte interventies. Zijdelings maken we gewag van de samenhang met voorzieningen en regulering. Hier willen we er nogmaals op wijzen dat voorlichting zowell ondergeschikt, bovengeschikt en nevengeschikt ingezet kan worden. Voorlichting in combinatie met voorzieningen en/of regulering zijn echter niet het object van studie geweest. 
Beknopt hebben we de ontwikkelingsgang van GVO geschetst: aanvankelijk als overdracht van medisch informatie aan grote groepen van de bevolking, later de nadruk op eigen verantwoordelijk/mondigheid via participatie en kleinschalige groepsactiviteiten. Thans zien we een duidelijke tendens in de richting van gezondheidsbevordering en Health Promotion via integratie in het gezondheidsbeleid.

Conform onze opvattingen, geventileerd in hoofdstuk 1, beschouwen we GVO als een vorm van intentionele voorlichting. Op basis van recente literatuur over beïnloeding van gedrag dient intentionele voorlichting gefundeerd te zijn op drie pijlers namelijk doelgerichtheid, planmatigheid en systematiek Deze drie elementen vinden we ook terug in de Health Education Poverty Cycle van Green (1986). We onderstrepen de gedachtengang van Green dat een gezondheidseducatieve interventie vooraf dient te gaan door een grondige probleemanalyse en een degelijk onderzoek naar gedragsdeterminanten. Voorts dient serieus aandacht geschonken te worden aan operationele doelen, die afgestemd dienen te worden op de afzonderlijke fasen in het voorlichtingsproces.

In dit hoofdstuk hebben we over gezondheidseducatieve interventies in het algemeen gesproken, in het navolgende concentreren we ons op wat men in de volksmond "campagnes" noemt, namelijk interventies via de massamedia. 



\section{Hoofdstuk 3 Motivatie als aangrijpingspunt voor verandering}

3.1 Inleiding

3.2 Nadere begripsbepaling

3.3 Motivatie; determinanten van gedrag

3.4 Categorisering van gedragsdeterminanten

3.5 Van instincten via driften naar cognities

3.6 Cognitieve motivatietheorieën

3.7 Cognitieve consistentietheorieën

3.8 De ontwikkeling van fundamentele behoeften tot concrete motieven

3.9 Slotbeschouwing

\subsection{Inleiding}

In nagenoeg alle recent verschenen proefschriften met betrekking tot GVO treffen we de constatering aan dat voorlichting slechts effectief is als ze aansluit bij de wensen, verwachtingen, behoeften, motivatie en ervaringen van de doelgroep. Deze opsomming is klaarblijkelijk boven iedere twijfel verheven; ze wordt als basisprincipe van voorlichting gehanteerd. De afzonderlijke begrippen van bovengenoemde constatering verwijzen alle naar psychische gesteldheden of belevingen. Men zou ze ook met de term motivationele gedragsdeterminanten kunnen aanduiden; ze vormen de sleutel tot verandering van gedrag. Haastig voegen we daaraan toe dat ook fysiologische en 
somatische factoren gedrag kunnen bepalen. Deze laatste laten we buiten beschouwing, omdat ze middels intentionele voorlichting niet of nauwelijks te beînvloeden zijn.

Kok (1986) spreekt in zijn oratie over gezondheidsmotivering: "GVO probeert gedrag te beinvloeden door mensen te motiveren tot ander gedrag" (pag. 14). Kok gaat zelfs zover dat hij motivatie niet alleen als noodzakelijke voorwaarde voor vrijwillige verandering ziet maar zelfs bij gedwongen verandering (middels wet en regelgeving) onontbeerlijk vindt. In een variant op het Health Belief Model (Antonovsky en Kats, 1977) wordt gezondheidsmotivatie als uitgangspunt gehanteerd. De motivatie tot gezondheidsgedrag is gericht op drie doelen, namelijk het behouden van gezondheid en het vermijden van ziekte, het verkrijgen van instemming/steun van significante anderen en het verkrijgen van selfapproval (zelfbevestiging).

Het begrip motivatie is een theoretisch construct, dat nadere operationalisering behoeft om als instrument te dienen om gedrag te sturen. Doorgaans is niet éen motief een beweegreden tot handelen, maar spelen meer motieven en combinaties van motieven een rol, die op hun beurt weer afhankelijk zijn van tal van factoren. Dat verklaart het feit dat motivatie een zeer moeilijk te operationaliseren term is (Jonkers, 1978). Motivaties onttrekken zich aan directe waarneming; ze zijn slechts uit gedrag af te leiden. Motivatie is een container-begrip dat vanuit verschillende disciplines wordt ingevuld; wellicht is dat de reden dat er zoveel empirische en conceptuele verwarring rond dit begrip is. Daar komt bij dat het gedrag van mensen niet altijd rationeel of bewust gebeurt. Zo kunnen spontane uitingen opeens de boventoon voeren zonder dat men kan aangeven hoe dat komt. In de regel heeft een persoon wel een reden of uitleg waarom hij zich op een bepaalde manier gedraagt. Zodra hij de uitleg onder woorden kan brengen, dus kan duiden, wordt van motivering gesproken. Hierbij moeten we wel aantekenen dat de opgesomde redenen niet persé waar of objectief hoeven te zijn. Het kan namelijk voorkomen dat men alleen gewag maakt van bewuste motieven, terwijl onderbewuste motieven moeilijker aan het licht komen. Het verschil tussen motivatie en motivering wordt ook weleens tot uitdrukking gebracht in het onderscheid tussen extrinsieke versus intrinsieke motivatie. Dit onderscheid berust op de veronderstelling dat de prikkel tot gedrag zowel binnen als buiten de persoon kan liggen. Zodra sprake is van stimulering vanuit de omgeving van de persoon, wordt van extrinsieke motivatie gesproken. Is de persoon zelf de bron van motivatie dan 
wordt dit intrinsieke motivatie genoemd (Ross en Mico, 1980). De persoon handelt op een bepaalde wijze die hij zelf nodig acht, hem de meeste bevrediging schenkt of hem in staat stelt zelfgekozen doelen te bereiken. In contrast hiermee staat de extrinsieke motivatie die afhankelijk is van wat anderen belangrijk vinden of in de ogen van anderen waardering geniet. Meestal staat hier een positieve sanctionering tegenover.

In zijn algemeenheid kunnen we stellen dat de term motivatie verwijst naar een drijvende kracht achter het menselijk handelen, de dynamiek die mensen ertoe aanzet bepaalde dingen te doen of na te laten. De vraag "wat motivatie is?" is in feite de vraag naar de aard, omvang, intensiteit en oorsprong van beweegredenen, die aan het menselijk handelen ten grondslag liggen. In de volgende paragrafen doen we een poging om het begrip motivatie te verhelderen, in die zin dat het voor de toepassing van voorlichting hanteerbaar wordt. In het navolgende zullen we een korte "sightseeing" maken door de literatuur, teneinde te achterhalen hoe het begrip motivatie zich in het wetenschappelijk denken heeft ontwikkeld. Vervolgens zullen we ons verdiepen in de aard van de motivatie, de verschillende vormen waarin de motivatie zich manifesteert en tenslotte beschrijven we welke consequenties motivatie(s) heeft voor massamediale voorlichting. We vangen aan met een nadere begripsbepaling.

\subsection{Nadere begripsbepaling}

Het onderzoek naar en de theorievorming over motivatie is een van de meest controversiële onderwerpen in de psychologie. Velen hebben getracht ordening aan te brengen in de talrijke motivatie-theorieën. Bekend is de poging van Madsen (1968) om met behulp van wetenschappelijke criteria de belangrijkste motivatie-theorieën te categoriseren. De slotsom van zijn omvangrijk werk is dat de geleerden het onderling grondig oneens zijn ten aanzien van inhoud, begrippenapparaat, reikwijdte en vraagstelling.

Duyker (1976) verstaat onder motivatie: "a. het totaal van beweegredenen dat op een bepaald ogenblik werkzaam is; b. de mate waarin (sommige) beweegredenen op een bepaald moment werkzaam zijn". Beweegredenen vormen de kern van Duykers definitie, die in wezen twee vraagstellingen bevat, namelijk naar de aard van of soort determinanten van gedrag en naar de intensiteit van de determinan- 
ten. Nuttin (1980) ziet de psychologische benadering van motivatie van gedrag als een relatiefunctie; motivatie is het dynamische aspect van het in relatie treden van subject en wereld (omgeving en milieu). De relatie-functie moet helderheid verschaffen over wat de aard van de objecten is waarop het subject zich richt en volgens welke processen de motivering van gedrag verloopt. In Nuttin's opvatting is motivatie zowel een drijvende kracht (uitgaande van het organisme) als een zuigende kracht uitgaande van het object. Het uitgangspunt dat Nuttin kiest, namelijk dat gedrag relationeel bepaald is, impliceert dat hij noch bij een (intra)organische stimulus, noch bij de omgeving van het individu, maar in het dynamische karakter van juist de relatie die het individu met zijn omgeving aangaat het grondfenomeen van motivatie bespeurt. Het grondfenomeen betreft het functioneren van het individu: "Functioneren, optimaal functioneren, dat is voor elk levend wezen het eerste vereiste en daarom de bron van zijn dynamiek" (pag. 14). In concreto wil Nuttin bij de bestudering van motivatie weten: 1 . Wat is de inhoud van motivatie? ("datgene wat het individu tracht te bereiken, tot stand te brengen of juist te vermijden") en 2. Wat zijn de mechanismen van de motivatie en vooral het effect van de cognitieve processen op de ontwikkeling en concretisering van behoeften? Op deze laatste vraag komen we in paragraaf 3.8 terug.

\subsection{Motivatie; determinanten van gedrag}

Er is geen theorie over de motivatie. Eensgezindheid bestaat er over het feit dat motivatie betrekking heeft op determinanten van gedrag. Echter, daarmee is de vraag "waarom gedraagt iemand zich op een bepaalde manier", niet beantwoord. Volgens ingewijden in het motivatie-onderzoek is er tot op dit moment geen theorie die de waaromvraag kan beantwoorden. Duyker geeft daar als verklaring voor dat menselijke situaties in het algemeen onuitputtelijk zijn en daarmee het aantal mogelijke gedragsdeterminanten oneindig.

Om deze materie voor de voorlichting enigszins hanteerbaar te maken, volgen we Duyker, die een algemeen "principieel" overzicht heeft geschetst van factoren die bepalend zijn voor menselijke activiteiten.

1. Er is een samenhang tussen lichaam en gedrag: het gedrag is dus tot op zekere hoogte biologisch gedetermineerd. Een ziekte of 
kwaal kan het functioneren ernstig belemmeren. Duyker stelt: "Onder alle omstandigheden - normale zowel als afwijkende vormt ons lichaam het totaal van onze gedragsmogelijkheden" (pag. 451).

2. De mens is voor zijn functioneren afhankelijk van zijn fysieke en sociale omgeving. Er bestaat een relatie tussen lichaam en omgeving via waarneming: " $\mathrm{Er}$ is niets in de waarneembare werkelijkheid dat niet het gedrag zou kunnen bepalen" (pag. 451).

Duyker gaat nog een stap verder en stelt dat er niets denkbaar is dat niet het gedrag zou kunnen bepalen. Het behoeft weinig betoog dat hetgeen denkbaar is veel meer omvat dat wat waarneembaar is. De verzameling van het denkbare is oneindig, ergo het aantal mogelijke determinanten van menselijk gedrag staat geen eenvoudige oplossing toe. Maar, voegt Duyker eraan toe, niet alle determinanten zijn even belangrijk.

\subsection{De categorisering van de gedragsdeterminanten}

Duyker poogt in het oneindig aantal determinanten ordening aan te brengen door de determinanten onder te brengen in vier categorieën, namelijk:

1. limitatieve determinering

2. normatieve determinering

3. operatieve determinering

4. motivationele determinering.

Tot de limitatieve determinanten worden die determinanten gerekend, die aan zekere grenzen gebonden zijn en die beperkingen aanbrengen in onze activiteiten. Lichamelijke factoren en intellectuele capaciteiten kunnen gelden als voorbeelden van limitatieve determinanten.

Normatieve determinering heeft betrekking op gedragingen die gebonden zijn aan bepaalde regels en normen. De te hanteren normen verschillen van cultuur tot cultuur en van subcultuur tot subcultuur. Zonder normen en regels zou het samenleven chaotisch worden. Normen en regels leggen enerzijds in zekere zin beperkingen op, anderzijds scheppen zij sociale ruimte met posities, afstanden, rollen, omgangsvoorschriften, etc. (zie ook paragraaf 2.4). 
De derde categorie betreft de operatieve determinering: determinanten, die we door leren verworven en ontwikkeld hebben. Door opvoeding krijgt de mens een blijvend stempel opgedrukt. Ook ervaringen, de gehele reeks van activiteiten, die men bewust of onbewust onderneemt, bepalen (potentieel) gedrag.

Tot slot is er de motivationele determinering, die Duyker gelijk stelt met behoeften. Ofschoon Duijker niet bijster origineel is in zijn opvattingen over behoeften zullen we toch enige exercitie plegen om de oorsprong, dat wil zeggen de eerste gedachtenvorming over behoeften te beschrijven. Hierbij zij aangetekend dat we het idee dat behoeften equivalenten zijn van motivatie, niet delen.

Freud en andere drifttheoretici gaan uit van het idee dat mensen iets gewaarworden tengevolge van interne prikkels, bijvoorbeeld honger. Deze prikkels kunnen zowel aangenaam als onaangenaam beleefd worden. Aangename prikkels proberen we te behouden; onaangename prikkels proberen we te minimaliseren. Volgens de Nirwanatheorie (Freud e.a.) is het streven van de mens gericht op een toestand van (interne) prikkeloosheid. Behavioristen huldigen ongeveer dezelfde ideeën; om zich te handhaven moet het individu zekere activiteiten ontplooien. Deze activiteiten worden gevoed door signalen, die optreden wanneer de mens bemerkt dat zijn optimale kansen om voort te bestaan in gevaar komen. Dit signaal wordt ervaren als een een behoefte (need) en brengt krachtens zijn aard het organisme in beweging. De aanhangers van de Freudiaanse theorie, zoals de behavioristen, zien een drift als het gevolg van een verstoring van een (biologisch) optimale toestand. Volgens Nuttin (1981) zijn de behavioristische theorieën over het gedrag in het algemeen en motivatie in het bijzonder volstrekt ontoereikend. De belangrijkste reden daarvoor is dat de behavioristen de cognitieve functies uitsluiten van wetenschappelijke uitleg van het menselijk gedrag. Voor Nuttin geldt dat het hele functioneren van de mens in hoge mate wordt beïnvloed door de ontwikkeling van zijn cognitieve functies. Voor voorlichting is het cognitieve domein zeer relevant; vandaar dat wij dieper op dit thema ingaan.

\subsection{Van instincten via driften naar cognities}

Het gedrag van mensen beslaat een brede waaier van gedragingen waarachter een onuitputtelijk aantal activiteiten schuilgaat. Aan die 
gedragingen liggen biologische, ethologische, fysiologische en psychologische motivaties ten grondslag. In dit werk beperken we ons tot (sociaal-)psychologische verklaringen.

In de naturalistische theorieèn gaat men ervan uit dat mensen beheerst worden door een animaal driftleven, dat wil zeggen dat men redeneert vanuit het idee van Darwin, namelijk het vergroten van de overlevingskansen. In die dagen, de jaren twintig, ging men uit van een mechanistisch mensbeeld: oorzaak en gevolg zijn uniliniair, dus zonder tussenkomst van psychische en sociale processen. Het gedrag werd gedreven door instincten, een serie reflexen die bepaalde spieren in gang zetten. Het instinctmatig handelen werd door de behavioristen naar de achtergrond gedrongen. $\mathrm{Zij}$ waren namelijk niet zo geïnteresseerd in het verklaren van gedrag, alswel in het voorspellen van het gedrag op grond van omgevingsvariabelen: het gedrag van mensen werd opgevat als een reactie op een prikkel uit de onmiddellijke omgeving. Deze opvatting heeft faam verworven onder de titel het Stimulus-Respons-model. Tolman (1886 - 1959) heeft het StimulusRespons-model verder geperfectioneerd door de aandacht te vestigen op interveniërende variabelen, omdat eenzelfde stimulus verschillende veranderingen teweeg kan brengen. Het gedrag is niet alleen verklaarbaar uit de aard van de prikkel maar veeleer door de toestand(en) waaronder die prikkel wordt toegediend aan het organisme. Hij voegde daarom aan het Stimulus-Respons-model een reeks interveniërende variabelen toe: de mens (het organisme) met zijn verwachtingen, behoeften en vaardigheden zag Tolman als bemiddelaar tussen de prikkel uit de omgeving en het waarneembare gedrag.

Het Stimulus-Respons-model werd vervangen door het StimulusOrganisme-Respons-model. Met de introductie van dit model werd een stap gezet in de richting van de cognitieve psychologie. De drijfveer tot handelen wordt niet bepaald door driften, maar door cognities in de zin van intervenierende variabelen, onder andere de verwachting die men heeft over de bereikbaarheid van een doel en de waarde die men aan dat doel toekent. De verklaring van gedrag i.c. de motivatie werd hiermede voor een belangrijk deel toegeschreven aan cognitieve elementen. De onlangs overleden psycholoog Skinner, ook behorend tot de behavioristische school, heeft de invloed van de intervenierende variabelen gerelativeerd door te wijzen op het belang van de toediening van de juiste prikkel op het geschikte ogenblik.

Door het benadrukken van cognities (intentionaliteit, verwachtingen, etc.) als gedragsdeterminant treden de sociale aspecten van de men- 
selijke motivatie als studie-object steeds meer op de voorgrond. Het sociaal-psychologisch onderzoek, waarin men uitgaat van het idee dat de mens gedetermineerd wordt door zijn sociale en culturele omgeving en daarmede een produkt is van zijn tijd, krijgt de overhand. Zo spreekt Allport (1937, 1961) in zijn persoonlijkheidstheorie over bewuste motivatie; in de loop van de levensjaren ontwikkelt het individu zijn oorspronkelijk biologische motieven uit de kinderjaren tot autonome functies. Aan die autonome functies ontleent de mens zijn unieke karakter. Volgens de opvatting van Allport berust de bewuste motivatie op functionele autonomie, namelijk het doelbewust amgaan met uiteenlopende prikkels die leiden tot activering van een bepaalde handeling of tot vermijding of vertraging van bepaalde handelingen. Allport merkt daarbij op dat de handelingen steeds gericht zijn op doelen in de toekomst.

De humanistische psychologen (Maslow, Rogers et al.) zetten zich af tegen het idee dat mensen streven naar een psychologisch evenwicht (homeostase). Zij postuleren dat mensen steeds op zoek zijn naar nieuwe doelen en in principe geneigd zijn om zijn of haar kwaliteiten en vaardigheden verder te ontwikkelen. Een belangrijke representant van de humanistisch psychologische stroming was Maslow, die de begrippen behoeften en motivatie met elkaar verstrengelt. In zijn theorie van de zelfverwerkelijking (1962) wordt gesteld dat behoeften hiërarchisch gestructureerd zijn. Hierbij wordt onderscheid aangebracht tussen de basale fysiologische behoeften en psychologische behoeften. Het idee achter de behoeftenhiërarchie is dat eerst lagere behoeften (de zogenaamd elementaire behoeften) bevredigd worden vooraleer men toekomt aan bevrediging van de hogere behoeften (de zgn groei-behoeften). Deze laatsten zijn op te vatten als de motivatie tot zelfverwerkelijking. Door zelf-actualisatie (zelfverwerkelijking) tracht men de aanwezige potenties (spontaniteit, creativiteit, probleemoplossend denken, etc.) vorm te geven en verder te ontwikkelen.

\subsection{Cognitieve motivatietheorieën}

Deze theorieèn hebben gemeen dat ze de mens beschouwen als een rationeel wezen dat "tot op zekere hoogte" zijn lot weet te beheersen en zichzelf mogelijkheden kan scheppen om zijn behoeften te bevredigen. De beperking in de vorige zin "tot op zekere hoogte" heeft betrekking op het feit dat men (de invloed van) de sociale context 
waarin zich de handelingen afspelen, als serieuze gedragsdeterminant beschouwt. De verwachting die men koestert op grond van weten, vermoeden, hopen, vrezen, etc. bepaalt of en in welke richting beslissingen worden genomen ten aanzien van de verwezenlijking en de waarde van een bepaald doel.

Lewin en zijn epigonen trachtten het gedrag te analyseren door het individu te benaderen vanuit een psychologisch krachtenveld: de in een situatie (de life space of levensruimte is de door de persoon waargenomen omgeving) aanwezige spanningssystemen zijn de motiverende krachten. Het opheffen van de spanningen binnen de levensruimte doet vermoeden dat aan het sociale functioneren van mensen het homeostase-principe ten grondslag ligt. Het gedrag (de locomotie is het doelgericht handelen van intentie naar eindtoestand of satisfactie) is de resultante van de persoon zoals die zichzelf ervaart en de omgeving zoals die wordt waargenomen. Locomotie is dus het gevolg van de spanning tussen persoon en omgeving. Op basis van deze ideeën heeft Lewin later de groepsdynamica tot ontwikkeling gebracht. In wezen kan de theorie van Lewin niet als cognitieve motivatietheorie worden aangemerkt. De grondslag van de cognitieve motivatie berust meer op:

1. de verwachting (expectance) die iemand heeft over het (kunnen) bereiken van een bepaald doel en

2. de waarde (value) die dat doel voor de persoon in kwestie heeft.

De sterkte van de motivatie is door Atkinson en Feather (1966) neergelegd in de "Valentie $x$ Waarschijnlijkheid - theorie". De motivatie schuilt dan in de aansporing (incentive) om dat doel te bereiken. Deze redenering is vaak gehanteerd in het prestatie-motivatie-onderzoek. Het streven naar een prestatie is een gedraging die beïnvloed wordt door iemands verwachting over het falen of slagen in een bepaalde taak.

Atkinson $(1966,1970)$ heeft de prestatie-motivatie verfijnd door te wijzen op de individuele verschillen in motivationele processen. In zijn risicomodel wordt de persoonlijkheidsstructuur als gedragsdeterminant opgenomen. Vanuit Atkinsons optie is prestatiegedrag het resultaat van een conflict tussen de hoop op succes (prestatie-motivatie) en faalangst (vermijdingsmotivatie). De moeilijkheidsgraad van de op te lossen taak lijkt hier meer aan de orde dan de motivatieprocessen die aan het oplossen van de taak voorafgaan; aan de feitelijke cognitieve processen (het verwerken, omgaan en opslaan van infor- 
matie) is slechts bescheiden aandacht besteed. De evenwichtstheorieën (de cognitieve consistentietheorieên) bieden, wat dat betreft, meer houvast om de motivatie nader te beschrijven.

\subsection{De cognitieve consistentietheorieèn}

In de consistentietheorieën staat het streven naar een evenwicht tussen verschillende cognitteve elementen centraal. Om een betekenisvol beeld van de werkelijkheid te krijgen, probeert de mens de prikkels uit de omgeving coherent te ordenen. Dit betekent dat ideeën, opvattingen, meningen en gedrag elkaar dienen te ondersteunen. Wanneer twee van de genoemde elementen strijdig zijn met elkaar, bijvoorbeeld wanneer opvattingen en gedrag elkaar tegenspreken of met elkaar conflicteren, is er sprake van inconsistentie. De meest bekende en eenvoudige consistentietheorie, de zogenaamde balanstheorie van Heider (1958) gaat er vanuit dat het individu de elementen van de sociale werkelijkheid verenigbaar, coherent en consistent probeert te maken. Indien het individu uit balans raakt, wordt dit door hem als onplezierig ervaren met als gevolg dat hij deze onplezierige toestand op enigerlei wijze zal trachten te veranderen. Dit streven naar evenwicht wordt verantwoordelijk geacht voor cognitieve veranderingen. De balanstheorie van Heider is slechts van toepassing in zeer eenvoudige situaties en is daarmee ontoereikend om de complexe werkelijkheid te verklaren. Volgens Kiesler et al. (1969) dekt de theorie de mogelijke cognitieve en evaluatieve relaties uit de praktijk niet en zijn er geen gradaties mogelijk in de relaties omdat het model uitgaat van relaties uitgedrukt in absoluut positief of absoluut negatief. Ondanks deze tekortkomingen heeft het oorspronkelijke model van Heider gediend als basis voor de opvattingen van Feather (1967), Rosenberg en Abelson (1960), Newcomb (1961) en vele anderen.

Feather (1967) heeft het model toegepast op overredende communicatie; de bron, de boodschap, de inhoud van de boodschap en de ontvanger worden opgevat als deelaspecten van de communicatiestructuur waartussen positieve of negatieve relaties bestaan.

De cognitieve dissonantietheorie van Festinger (1957) neemt een aparte plaats in binnen de consistentie-theorieën. De theorie gaat er van uit dat twee cognitieve elementen, die aan elkaar gerelateerd zijn, onderling verenigbaar dienen te zijn (consonant). Indien de cognitieve 
elementen niet met elkaar in overeenstemming zijn of als de een niet uit de ander voortvloeit, is er sprake van dissonantie. Preciezer geformuleerd: dissonant is als A het tegenovergestelde van B impliceert. Door cognitieve dissonantie raakt de persoon uit evenwicht, omdat de dissonantie als psychologisch onplezierig wordt ervaren. Het individu zal er dus naar streven om het evenwicht in de cognitieve elementen te herstellen. Dissonantie-reductie kan op verschillende manieren plaatsvinden: door situaties te mijden, het gedrag te wijzigen, nieuwe cognities toe te voegen of te selecteren of de bron van een bericht minder serieus te nemen.

Een schakel tussen de balanstheorie van Heider en de attributietheorieën is de corresponderende inferentietheorie van Jones en Davis (1965). Deze theorie gaat er vanuit dat mensen zoeken naar zinvolle verklaringen voor gedrag van anderen. Het gedrag van anderen is voor de waarnemer met name informatief wanneer er sprake is van intentioneel handelen. Op basis van de verworven informatie vormt zich een corresponderende inferentie, die als motivatie voor eigen gedrag kan worden aangewend.

De motivatie van een subject kan beïnvloed worden, doordat een handeling of gedrag aan een bepaalde externe of interne oorzaak wordt toegeschreven. De attributietheorie beschrijft de wijze waarop mensen oorzaak-gevolg relaties waarnemen. Oskamp (1977) is van mening dat er geen sprake is van een theorie maar van een stroming met als gemeenschappelijk kenmerk de vraag hoe op basis van oorzakelijke gevolgtrekkingen uit eigen handelen, uit het gedrag van anderen en uit wat zich in de omgeving afspeelt, bepaalde oordelen worden gevormd. Het motivatieprincipe in ieder attributieproces is de beheersing van de causale structuur van de omgeving (Metaal en Fischer, 1985). Mensen zoeken naar een verklaring voor gebeurtenissen in hun omgeving en leiden oorzaak-gevolgrelaties af uit hun waarnemingen. Volgens het covariatiemodel van Kelly (1967) maken mensen een attributie op basis van informatie met betrekking tot distinctiviteit, consensus en consistentie. Als het gedrag covarieert met verandering in de omgeving, dan wordt de omgeving verantwoordelijk gesteld. Er is dan sprake van externe attributie. Men spreekt van interne attributie als het gedrag covarieert met iets waarvoor men zelf verantwoordelijk is. Of men intern dan wel extern attribueert is afhankelijk van: 
1. of bepaald gedrag zich onderscheidt of afwijkt van algemeen gedrag bil een bepaalde gebeurtenis (distinctie),

2. of men nagaat of veel of weinig mensen op een specifieke gebeurtenis reageren (consensus),

3. of men nagaat of op een bepaalde stimulus vaker of minder vaak op dezelfde wijze wordt gereageerd (consistentie).

Van interne attributie is sprake bij lage distinctiviteit, lage consensus en hoge consistentie. Ergo geldt dit voor externe attributie, namelijk hoge distinctiviteit, lage consensus en lage consistentie. Wiegman, De Roon en Snijders (1981) stellen dat de bijdrage van Kelly aan de attributiebenadering gekenmerkt wordt door een verhoogde belangstelling voor externe attributie met betrekking tot sociale beinvloeding.

\subsection{De ontwikkeling van fundamentele behoeften tot concrete motieven}

Volgens Nuttin (1981) zijn er in wezen drie mechanismen die de werking van de motivatie, dat wil zeggen het activeren en richten van gedrag, kunnen verklaren:

1. Het ontladingsmechanisme: interne prikkels in het organisme veroorzaken een teveel aan energie die ontladen wordt middels lustgevoelens (Freud).

2. Het mechanisme van de connectie of de versterkte reactie; de stimulus is het beginpunt van een associatie tussen aangeleerde of versterkte connecties tussen prikkel en reactie (Thorndike, Pavlov).

3. Mechanismen die gebaseerd zijn op de werking van het informatieproces; motivatie wordt opgevat als gegeneraliseerde activatie - of "arousal" toestand veroorzaakt door informatie. Het mechanisme wordt uitsluitend gezien als een spanningsreducerend proces derhalve wordt de motivatie opgevat als de reductie van een behoefte.

Nuttin is van mening dat motivatie niet alleen gezien moet worden als een effect van behoeftebevrediging, maar dat veel meer aandacht geschonken moet worden aan de oorsprong van de motivatie, namelijk de vraag hoe die behoeften onstaan. Hij onderscheidt twee fasen (de opgaande fase en de constructieve fase) in het motivatieproces om aan te geven hoe behoeften zich ontwikkelen tot concrete doelstellin- 
gen en projecten. In de opvatting van Nuttin zijn behoeften tot op zekere hoogte gekanaliseerd en aangeleerd. Naarmate men vaker de weg van behoefte naar concreet object heeft afgelegd, worden de ervaringen positiever (response learning); het gevolg is dat het subject zichzelf nieuwe criteria stelt bij het behalen van nieuwe resultaten en te verwezenlijken doelen. Bevredigingen uit het verleden en herhaalde ervaringen worden in de toekomst niet als voldoende belonend ervaren. Dit resulteert in activatie van behoeften en bij voortduring formuleren van nieuwe doelen. Om aan te geven hoe behoeften zich ontwikkelen tot concrete doelstellingen, deelt Nuttin het motivatieproces op in twee tegengestelde bewegingen: een neergaande beweging waarbij gestreefd wordt naar ontlading, evenwicht en rust en een opgaande beweging die het bereikte evenwicht en de rust verstoren en gericht is op het streven naar nieuwe doelen en een hogere staat van volmaaktheid (zwaardere verantwoordelijkheden) en het verleggen van het aspiratieniveau. De opgaande beweging is een cognitief proces dat gericht is op een optimaal functioneren, namelijk het realiseren van congruentie tussen de waargenomen situatie (de omgeving) en het beeld dat het subject van zichzelf heeft (de persoon die zichzelf kent). Op zintuiglijk vlak richt de persoon zich op lichamelijk welbevinden en op het psychologisch vlak naar verwerkelijking van aspiraties en doelen die de persoon zichzelf stelt. De vraag is nu welke doelen (maatstaven) worden gehanteerd. De mens construeert voorzich zelf een standaard, dat wil zeggen geeft een subjectieve definitie van de situatie waarin hij zich bevindt. In zijn streven naar lichamelijk welbevinden en zelfverwerkelijking formuleert hij een doelobject. De discrepantie tussen de standaard en het doelobject regelt de actie; er worden mechanismen in gang gezet om congruentie te bereiken. Het concipiëren van een standaard is de resultante van een ingewikkeld proces en berust op ervaringen, waarnemingen en denken. Ervaringen hebben betrekking op het al dan niet aangenaam zijn van de relaties met de omgeving. Lust of onlust regelt een groot deel van het primaire gedrag, dat getekend wordt door biologische normen en opgedane ervaringen. De waarnemingen hebben betrekking op imitatie en de reproductie van waargenomen bewegingen (het streven te doen wat anderen doen). Naast waarnemen en ervaren - de motorische trial and error - kan de mens cognitieve verrichtingen (denken, creativiteitsvermogen, herinneringsvermogen) uitvoeren om doeltreffender en constructiever zijn stan- 
daard te formuleren. In grote lijnen komen de opvattingen van Nuttin overeen met de sociale leertheorie van Bandura (1977).

In het cognitieve domein is informatie beschikbaar over wat een individu, waargenomen, gedaan en geleerd heeft: er vindt een cognitieve concretisering van behoeften plaats, die leidt tot het construeren van een doelobject. Het doelobject is dus niet de bron van de motivatie. Motivatie is het resultat van een afwegingsproces van denken, waarnemen, en ervaren enerzijds en de middelen en handelingen om het doel te bereiken anderzijds. Nuttin (pag. 203) formuleert het als volgt "De overgang van ideële constructie in effectieve actie kan worden begrepen in het licht van een cognitieve theorie, waarin de cognitie en de manifeste handeling twee geïntegreerde componenten zijn van een zelfde overkoepelend gedrag (zich gedragen)".

\subsection{Slotbeschouwing}

In de inleiding van dit hoofdstuk hebben we voorzichtig laten doorschemeren dat dit hoofdstuk geen passend antwoord kan geven op het waarom en hoe van motivaties. Ook een sluitende definitie moeten we schuldig blijven; we hebben enkel gepoogd om enig licht te werpen op de gecompliceerdheid van motivationele gedragsdeterminanten.

Indien we de theoretische bespiegelingen van Nuttin trachten te modelleren voor de praktijk van de voorlichtingskunde, dan resulteert motivatie in een evaluatie van ervaringen, waarnemingen en gedachten. Op de keper beschouwd komt dit nagenoeg overeen met de intentie van gedrag, die we in courante sociaal-psychologische modellen voor gedragsverandering aantreffen (Fishbein en Ajzen, 1980; Kok, 1986). Fishbein en Ajzen spreken immers ook over een beredeneerd voornemen tot het uitvoeren van bepaalde handelingen hetgeen correspondeert met het begrip evaluatie in de zin van een afgewogen oordeel om bepaald gedrag te vertonen. In onderstaand model zullen we laten zien dat gedragsdeterminanten uit recente sociaal-psychologische theorieën een treffende overeenkomst vertonen met motivationele determinanten en geïntegreerd kunnen worden tot de evaluatie van denken, waarnemen en ervaren.

Enkele kanttekeningen bij deze figuur zijn gewenst. Allereerst wordt opgemerkt dat waarnemen, denken en ervaren per definitie niet op 
een rationele wijze gebeurt; zo kan bijvoorbeeld bij waarnemen selectieve perceptie optreden of ervaringen kunnen emotioneel verminkt zijn. Kortom, motivatie is niet louter rationeel, er zijn situaties in overvloed waarbij emoties sterk de overhand hebben. Ten tweede dient men er vanuit te gaan dat waarnemen, denken en ervaren doorgaans een kwestie van onderlinge interactie is. Ervaringen kunnen het denken in sterke mate beinvloeden en ergo geldt dit voor de beïnvloeding van het waarnemen. Het interactieve aspect hebben we in bovenstaand model tot uitdrukking willen brengen middels de gearceerde pijlen.

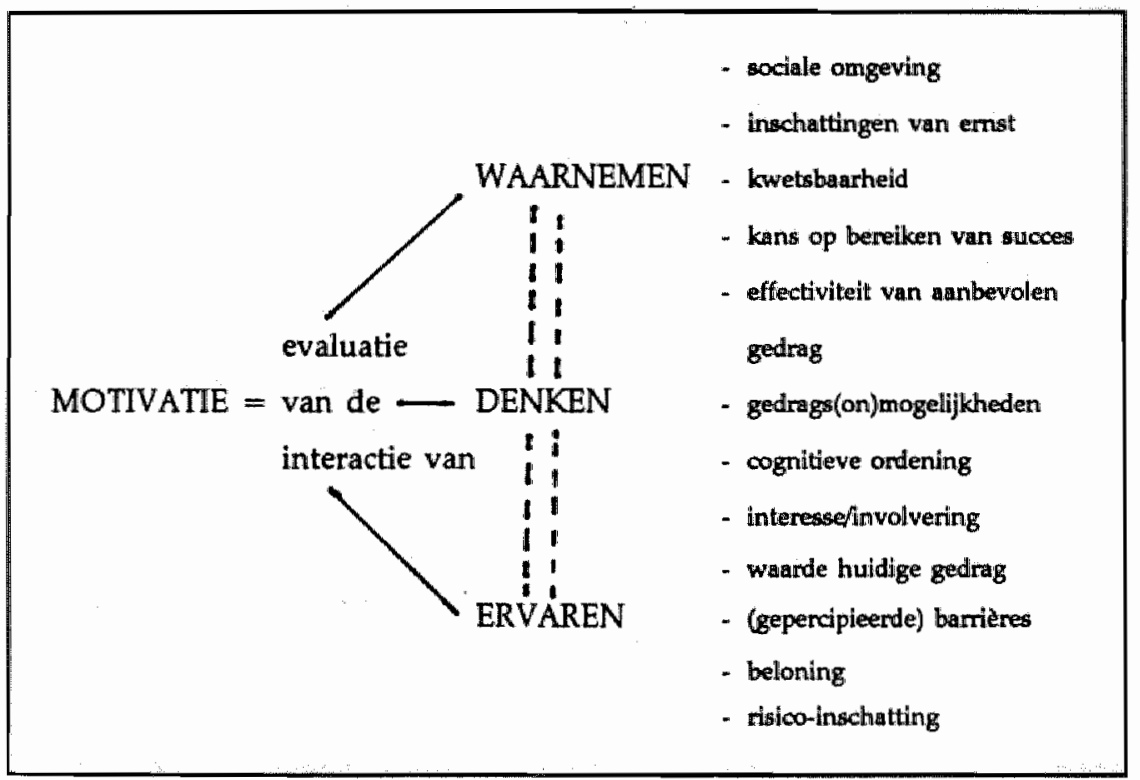

Figuur 3.1 Motivationele determinanten.

In de gezondheidsvoorlichting wordt nogal eens over het hoofd gezien dat gedrag een middel is om een doel te bereiken en geen doel op zich is. Dit gegeven zet kracht bij aan ons standpunt dat het om een evaluatie van ervaren, waarnemen en denken gaat ten opzichte van een bepaald doel. Uiteraard zal uiteindelijk het gedrag tot dat 
doel moeten leiden. Dit impliceert dat wannneer het doel dat de voorlichter zich stelt, in zijn geheel niet correspondeert met de waarde, die de ontvanger aan dat doel hecht, we de motivatie wel kunnen vergeten. Voorwaarde voor effectieve voorlichting is dan ook dat het doel relevant is voor de ontvanger. Het bepalen van het doel in de zin van een kosten/batenanalyse uit oogpunt van de ontvanger is in onze visie minstens zo belangrijk als het strategisch manipuleren van die factoren (i.c. de boodschapsvariabelen) die tot het gewenste gedrag leiden. Voorwaarden voor conformatie aan de voorlichtingsboodschap zijn cognitieve ordening en beloningsbenadrukking (Veen en Wilke, 1984). Het moge duidelijk zijn dat deze aspecten wel te onderscheiden maar niet te scheiden zijn. De professionele voorlichter moet in staat worden geacht om aan het principe van cognitieve ordening tegemoet te komen in die zin dat de boodschap op een gemakkelijke en begrijpelijke wijze bij de ontvanger overkomt. Aan het principe van beloningsbenadrukking - een positieve bekrachtiging - is moeilijker - zeker als het themata met betrekking tot gezondheidszorg betreft - te voldoen. Dit heeft een drietal redenen. Ten eerste, in het geval van gezondheid en ziekte speelt de risicoperceptie een belangrijke rol. Het is nooit met zekerheid te zeggen of ik een bepaalde ziekte wel of niet krijg. Ten tweede, het gedrag wat ik thans moet uitwoeren, sorteert pas effecten op de de lange termijn; er is geen sprake van een onmiddellijke gratificatie. Ten derde, de schadelijke gevolgen van het huidige gedrag zijn moeilijk in te schatten. Anders geformuleerd: de consequenties van het huidige gedrag (de ernst van de gevolgen gekoppeld aan de kans dat deze ook daadwerkelijk zullen optreden) en het gewenste gedrag (gepercipieerde effectiviteit van de aanbevelingen) zijn nogal triviaal.

In de literatuur bestaat concensus over het feit dat de grondslag van cognitieve motivatie allereerst berust op de verwachting die iemand heeft over het (kunnen) bereiken van een bepaald doel en op de tweede plaats op de waarde die dat doel voor de persoon in kwestie heeft. Bosman et al. (1989) spreken over maximalisatie van gedragsalternatieven. Mensen zijn geneigd om het alternatief te kiezen met de hoogste utiliteitswaarde. De utiliteitswaarde wordt door genoemde auteurs opgevat als "het product van de kans dat bepaalde consequenties op dat gedrag volgen en de waarde die we aan die consequenties hechten" (pag. 76). Voor intentionele voorlichting is met name de inschatting van die consequenties relevant, omdat de voorlichter probeert aan te geven welk gedrag verlangd wordt om het 
gewenste doel te bereiken. De inschatting van de consequenties van gedragsalternatieven is uitvoerig door Bandura $(1977,1982,1986)$ bestudeerd en geanalyseerd. Centraal in zijn theorie van het reciproque determinisme dat wil zeggen de wederkerige beinvloeding van persoon (persoonskenmerken, cognities), gedrag en externe omgeving - conform de opvattingen van Nuttin -, staan de uitkomstverwachtingen omtrent de effectiviteit van het opvolgen van het gewenste gedrag. In Bandura's theorie is gedrag de resultante van de gedragseffectiviteit in de zin van de perceptie omtrent de uitkomst van het opvolgen van het gewenste gedrag (helpt het?) en de eigeneffectiviteit namelijk de perceptie omtrent de eigen mogelijkheden om het aanbevolen gedrag ten uitvoer te brengen (kan ik het). Het zal duidelijk zijn dat in de voorlichtingsboodschap exact moet worden aangegeven om welk specifiek gedrag het, onder strikt gespecificeerde condities, gaat. Indien men in de voorlichting wil aansluiten bij de motivatie van de doelgroep, dan is het aangrijpingspunt het cognitieve verwerkingsproces ten aanzien van de effectiviteitsverwachtingen. 



\title{
Hoofdstuk 4 Het verwerven van informatie
}

\author{
4.1 Inleiding \\ 4.2 De ontvanger als uitgangspunt \\ 4.3 Uses and gratifications \\ 4.4 De instrumentele bruikbaarheid van informatie \\ 4.5 Het referentiemodel van het planmatig zoekproces \\ 4.6 De sense-making approach \\ 4.7 Slotbeschouwing
}

\subsection{Inleiding}

Conform onze opvattingen over intentionele voorlichting zal de voorlichter, die bepaalde veranderingen wil bewerkstelligen, strategisch te werk moeten gaan, namelijk effectief en doelmatig methoden en technieken aanwenden in het licht van de geformuleerde doelstellingen. Bij strategische planning is het onontbeerlijk om gegevens ter beschikking te hebben over verwachtingen, verlangens, behoeften en kennis van en over de doelgroep. Gedetailleerde gegevens over de doelgroep zijn niet alleen noodzakelijk voor het afstemmen/componeren van de boodschap, maar bovendien voor het segmenteren van de doelgroepen en de keuze van de media.

In dit hoofdstuk zullen we trachten aan te geven welke wegen de ontvangers kunnen bewandelen om informatie te vergaren en welke factoren in het spel zijn die bepalen hoe mensen omgaan met de 
media. In vogelvlucht zullen we de belangrijkste aspecten van informatiezoekgedrag weergeven voorzover zij van belang zijn voor voorlichting.

\subsection{De ontwanger als uitgangspunt}

De tijden dat de ontvanger als een willoos en passief wezen met betrekking tot mediaconsumptie werd afgeschilderd, zijn definitief voorbij. Thans gaat men er vanuit dat de ontvanger actief en selectief met de media omgaat. De voorlichter die een bepaald effect wil sorteren, doet er verstandig aan om het publiek serieus te nemen in dier voege dat hij de ontvanger opvat als een handelend persoon, die volgens bepaalde nutsprincipes van de media gebruik maakt. De overwegingen met betrekking tot mediaconsumptie door de ontvanger zijn enigszins vergelijkbaar met de motieven en intenties van de zender om te beïnloeden. In onderstaand massacommunicatiemodel van Maletzke (1963) wordt weergegeven dat zowel aan zenders als aan ontvangerszijde nagenoeg dezelfde factoren werkzaam zijn, namelijk; zelfbeeld, persoonlijkheid, lid van het publiek (groep) en sociale betrekkingen.

Maletzke (1963) gaat er vanuit dat zowel de ontvanger als de zender een beeld van elkaar hebben waardoor er wederzijdse beïnvloeding ontstaat. De zender zal rekening moeten houden met de spontane reacties van de ontvanger, die mogelijkerwijze leiden tot verandering van programma, vormgeving, etc.. In het model wordt aangegeven dat de zender drie soorten dwang ondergaat, namelijk:

1. Mediumdwang: de keuze voor een bepaald medium dwingt tot afweging van het functionele gebruik van het gekozen medium.

2. Boodschapsdwang: de inhoud en de vormgeving van de boodschap hebben consequenties voor de waarneming en beleving.

3. Openbaarheidsdwang: het feit dat men zich bedient van openbare media, betekent dat men in zekere mate gebonden is aan bepaalde normen, waarden, regelgeving en ethiek.

Met dit model van Maletzke, dat nog niet aan actualiteit heeft ingeboet, willen we illustreren dat de communicator niet de vrije hand heeft om de ontwanger te manipuleren of te beïnvloeden. Tevens geeft dit model aan dat met diverse factoren rekening gehouden moet worden, indien we met intentionele voorlichting aan de slag gaan. 


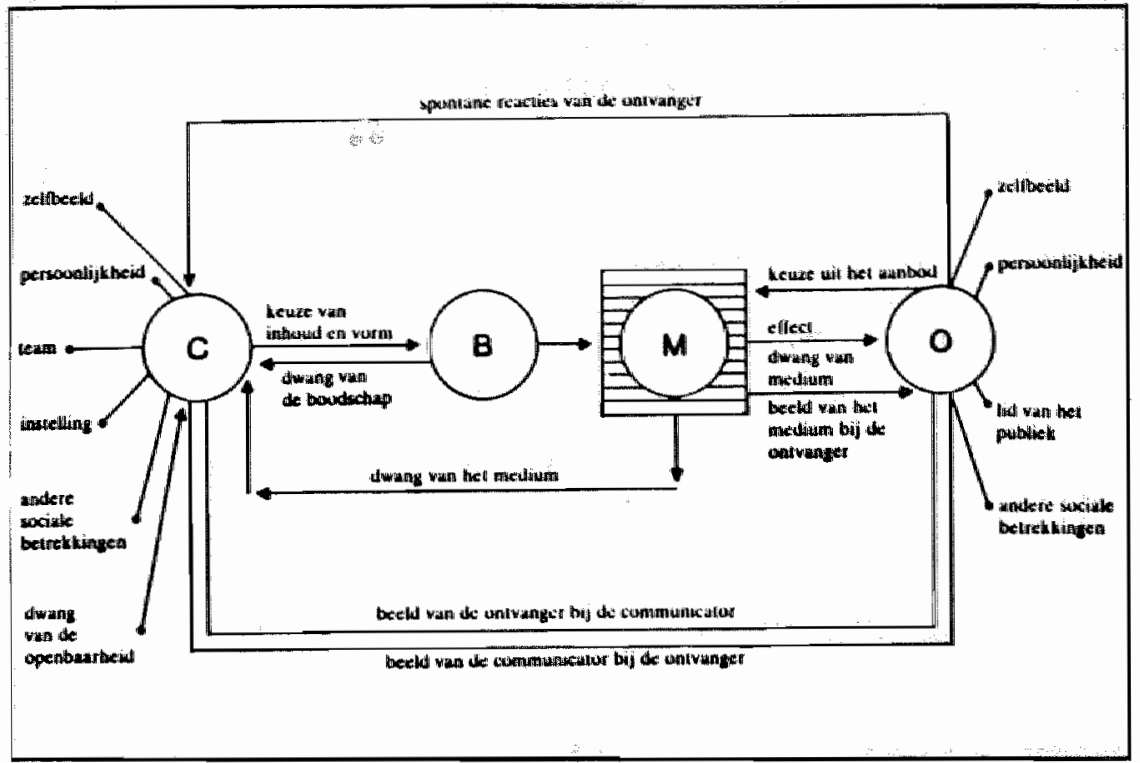

Figuur 4.1 Massacommunicatiemodel van Maletzke.

Bron: Maletzke, 1963.

Van Woerkum (1989) heeft vanuit de optiek van de zender de oriëntatie op ontvangers als volgt gekarakteriseerd.

1. De ontvanger als onbestemd eindpunt: de zender heeft geen expliciete intenties voor ogen.

2. De ontvanger als media-consument: de zender streeft naar een zo hoog mogelijk bereik en naar hoge kijk-, luister- en waarderingscijfers.

3. De ontvanger als object: de zender streeft er naar om bij de ontvanger een bepaald soort effect te bereiken.

4. De ontvanger als strateeg: de zender zal bij zijn streven naar een verandering zich terdege rekenschap moeten geven van het feit dat de ontvanger de ontvangst en verwerking van de boodschap kritisch en rationeel zal overwegen.

5. De ontvanger als subject: de zender confronteert de ontvanger met (nieuwe) informatie, die aanleiding kan geven tot reflectie, zingeving en vorming. 
De keuze, die de voorlichter kan maken uit deze oriëntaties, is sterk afhankelijk van de doelstelling die hem voor ogen staat en de keuze van het medium dat hij wil gebruiken.

Het zal weinig betoog behoeven dat de oriëntatie van "de ontvanger als strateeg" voor intentionele voorlichting als belangrijkste kan worden aangemerkt. Het gaat immers - over het algemeen - om activiteiten waarbij de ontvanger zich moeite moet getroosten om bepaalde zaken te doen of na te laten. Daarbij zal de voorlichter zich ervan bewust moeten zijn dat het steeds om vrijwillige verandering van ontvangers gaat. Dit impliceert dat de doelstellingen van de zender nauw moeten aansluiten bij de doelstellingen van de ontvanger. De Walle-Sevenster et al. (1986) spreken van een voorlichtingsparadox, als de doeleinden van de voorlichter en die van de ontvanger niet dezelfde zijn. Voorlichting is een betrekkelijk zwak instrument om veranderingen tot stand te brengen die tegen de belangen van de doelgroep indruisen. Röling (1989) somt drie voorwaarden op voor vrijwillige verandering:

1. mensen moeten weten hoe te veranderen,

2. mensen moeten willen veranderen,

3. mensen moeten kunnen veranderen.

In uitzonderlijke gevallen moeten ze ook nog mogen veranderen, bijvoorbeeld van religieuze leiders, peer groups, etc. (Galjart, 1971). Volgens Röling zijn vooral willen en kunnen door voorlichting te beïnvloeden. De belangen, doelen en verwachtingen van de ontvangers zijn soms zeer diffuus en latent; vandaar dat Kok $(1986,1987)$ er bij herhaling op heeft gewezen dat men zorgvuldig de doelpopulatie moet bestuderen en onderzoeken alvorens men overgaat tot implementatie.

Er zijn verschillende modellen in omloop die in vereenvoudigde vorm een abstractie van het communicatieproces in beeld brengen. Fauconnier (1980) heeft er meer dan vijftig in de wetenschappelijke literatuur geteld, die vanuit een structureel, dynamisch, functioneel of operationeel perspectief de visie van de auteur op het communicatieproces laten zien. Zoeken we naar modellen die inzicht verschaffen in het verwerven van informatie, dan is de oogst aanmerkelijk minder. Sommige modellen zijn gebaseerd op het StimulusResponse paradigma; bij andere is voortgebouwd op een functioneel model of ze zijn varianten op de "Uses and gratifications"-benadering. 
Het Stimulus-Response-paradigma komt eenvoudig gezegd hierop neer: stel iemand bloot aan een boodschap en hij zal leren. Aangezien er nauwelijks een lineaire relatie bestaat tussen ontvanger en boodschap is dit paradigma vervangen door het S-O-R-model (StimulusOrganisme-Response). Het idee achter dit model is dat er een aantal interveniërende variabelen tussen boodschap en ontvanger schuilgaan, die verantwoordelijk zijn voor verschillende effecten.

Een voorbeeld van het stimulus-organisme-respons-denken vinden we terug in de AIDA-formule uit de jaren twintig. De boodschap moest eerst aandacht vragen (A), daarna interesse opwekken (I), vervolgens verlangen stimuleren (D) en tenslotte tot actie aanzetten (A). Het staat buiten kijf dat stimulus-reponse-modellen ontoereikend zijn om het verwerven en verwerken van informatie te verklaren; het S-O-Rmodel biedt wat meer houvast, omdat daarin de interactie tussen aanbod en een individu uitdrukkelijk aan de orde wordt gesteld.

Ray (1973) veronderstelt dat er in zijn algemeenheid drie processen zijn die het verwerven van informatie kunnen verklaren, namelijk de leerhiërarchie, de dissonantie-attributie-hiërarchie en de low-involvement-hiërarchie. Zij hebben gemeen dat er cognitieve, affectieve en conatieve componenten in het proces betrokken zijn. De ordening van deze componenten geeft aan het proces een andere dimensie; bewustwording en attitude kunnen niet alleen aan het gedrag voorafgaan, maar kunnen er ook een gevolg van zijn. In onderstaand schema wordt de ordening van de verschillende processen afgebeeld.

Onder de cognitieve component verstaan we datgene wat te maken heeft met het verwerven en verwerken van kennis. De affectieve component heeft betrekking op de gevoelsmatige houding; een beoordeling in termen van voorkeur en afkeur. De conatieve component heeft betrekking op de intentie tot uitvoeren van gedrag en op het gedrag zelf.

Het verwerven van informatie is - volgens Ray - een dynamisch proces. Het optreden van verschillende processen is dan ook afhankelijk van:

1. betrokkenheid van de ontvanger bij de boodschap

2. mogelijke alternatieven

3. ervaring en kennis van de ontvanger. 


\begin{tabular}{|c|c|c|}
\hline $\begin{array}{l}\text { klassieke } \\
\text { leertheorie }\end{array}$ & $\begin{array}{c}\text { dissonantie-reductie } \\
\text { theorie }\end{array}$ & $\begin{array}{c}\text { low-involvement } \\
\text { theorie }\end{array}$ \\
\hline $\mid \begin{array}{l}\text { cognitief } \\
\text { affectief } \\
\text { conatief }\end{array}$ & $\mid \begin{array}{l}\text { conatief } \\
\text { affectief } \\
\text { cognitief }\end{array}$ & $\mid \begin{array}{l}\text { cognitief } \\
\text { conatief } \\
\text { affectief }\end{array}$ \\
\hline
\end{tabular}

Figuur 4.2 Processen van informatie-verwerving volgens Ray (1973).

Het belangrijkste verschil tussen bovengenoemde processen betreft de betrokkenheid van de ontvanger; in wezen is dit bepallend voor passief of actief informatiezoekgedrag.

De leerhiërarchie treedt op, als de ontvanger nauw bij de boodschap betrokken is en de mogelijkheid bestaat te kiezen uit alternatieven, die op relevante eigenschappen duidelijk verschillen. Van de dissonantiereductie-hiërarchie is sprake, wanneer er een hoge betrokkenheid is (dat wil zeggen feitelijk aangesproken worden op je eigen gedrag) en nagenoeg geen alternatieven die tegen elkaar afgewogen kunnen worden. De alternatieven verschillen weinig van elkaar of zijn moeilijk vast te stellen. De ontvanger makt een keuze en past zijn attitude aan de keuze aan. Achteraf zoekt hij rechtvaardiging voor zijn keuze en verhoogt daartoe zijn kennis over het gekozen alternatief.

De low-involvement-hiërarchie is toepasbaar, wanneer de betrokkenheid laag is en de alternatieven maar minimaal van elkaar verschillen. Door gebrek aan interesse is het informatiezoekgedrag passief en tegen nieuwe informatie die de ontvanger desondanks bereikt, bestaat weinig weerstand. Op basis van de beschikbare informatie kiest men voor gedrag. Naderhand ontwikkelt zich een attitude, die tot stand komt na afweging van de verschillende gedrags-alternatieven. Kline en Pavlik (1981) stellen dat massamediale campagnes, waarbij het de bedoeling is om gedrag te veranderen, uitgevoerd moeten worden in twee stappen. Allereerst moet de betrokkenheid opgevoerd worden totdat bewustwording ontstaat. Vervolgens zou men de leerhiërarchie (dat will zeggen cognitie beinvloedt attitude; attitude beinvloedt gedrag) moeten toepassen. Van Raaij (1984) plaatst vraagtekens bij de 
gangbare attitude-theorieën in die zin dat hij betwijfelt of affectieve reacties pas na cognitieve uitwerking komen. Hij stelt dat verwerking van informatie uit de massamedia volgt na een primaire affectieve reactie. De primaire affectieve reactie is te beschouwen als een eerste, snelle en globale beoordeling van het object, deze beoordeling behelst de beslissing of verdere informatieverwerving en -verwerking interessant $_{j}$ nuttig of nodig is. De primaire affectieve reactie bepaalt in hoge mate de daarna volgende cognitieve uitwerking. Van Raaij stelt: "Informatie dient niet zozeer om zich een oordeel te vormen, maar meer om het oordeel onder woorden te brengen en te rechtvaardigen" (pag. 269). We hebben de opvattingen van Ray en Van Raaij voor het voetlicht gehaald om aan te tonen dat de consumptie van mediaboodschappen geplaatst dient te worden in het sociaal en psychologisch kader waarin de ontvanger is gesitueerd en waarin hij op sellectieve wijze informatie verwerft en verwerkt. De "Uses en gratifications" benadering legt daarop de nadruk.

\subsection{Uses and gratifications}

Wil de voorlichter het belang dienen van de ontvanger dan zal hij zich rekenschap moeten geven van een aantal factoren, die voor de ontvanger bepalend zijn om kennis te nemen van de boodschap en deze te verwerken conform de bedoelingen van de zender. In de "Uses and gratifications" benadering staat het doelgerichte karakter van de media-consumptie centraal; het gaat hier om kwesties als welke sociale en psychologische factoren van invloed zijn op het media gedrag. De "Uses and gratifications" - benadering gaat uit van de veronderstelling dat de ontvangers van mediaboodschappen actief en selectief kiezen voor bepaalde media en de boodschappen ook naar eigen goeddunken verwerken. De ontvanger is dus niet een passief en willoos wezen, maar een actief en gemotiveerd gebruiker.

Mediagedrag moet beschouwd worden als gemotiveerd gedrag. Het wordt gestuurd door sociale en psychologische behoeften en door verwachtingen die men heeft ten aanzien van de beloningen of gratificaties die het gedrag opleveren. Mediagedrag berust dus op een complex van normen, waarden, behoeften en verwachtingen, die ingebed zijn in de culturele, sociale en psychologische context van alledag. Deze context verschilt van persoon tot persoon, van tijd tot tijd, en van cultuur tot cultuur (Staatsen, 1980). 
Katz et al. (1974, pag. 20) hebben de "Uses and gratifications"-benadering als volgt samengevat: "Studies are concerned with (1) the social and psychological origins of (2) needs, which generate (3) expectations of (4) the mass media or other sources, which lead to (5) differential patterns of mass media exposure (or engagement in other activities), resulting in (6) need gratifications and (7) other consequences ....". Vrij vertaald heeft de "Uses and gratifications"-benadering betrekking op sociale en psychologische factoren, die behoeften doen ontstaan waardoor verwachtingen gegenereerd worden ten aanzien van massamedia en andere bronnen van behoeftebevrediging, hetgeen leidt tot een gedifferentieerde mediaconsumptie of ander gedrag dat resulteert in behoeftebevrediging en andere gevolgen.

McQuail $(1972,1983)$ heeft vanuit het perspectief van de ontvanger het gebruik van de media in een typologie weergegeven (figuur 4.3).

We hebben de typologie van McQuail ten tonele gevoerd om te laten zien welke mogelijkheden/voorkeuren de ontvanger kan hebben om mediaboodschappen te consumeren. Terloops willen we er nog op wijzen dat de voorlichter zich met zijn boodschap op een informatiemarkt begeeft waar een felle concurrentiestrijd gevoerd wordt om de gunst van het publiek. Van Cuilenburg (1983) wijst in dit verband op het probleem van overinformatisering: een gespannen verhouding tussen de vraag en het aanbod van informatie. Gezien de concurrentie op de informatiemarkt en gelet op de mogelijkheden die de ontvanger heeft om zich bloot te stellen aan informatie (fysiek noodzakelijke selectie), is het voor de voorlichter van het grootste belang om zorgvuldig na te gaan op welke wijze hij zijn boodschap het best kan slijten. Indien we vanuit het oogpunt van massamediale voorlichting deze materie beschrijven, dan kunnen we ons het beste concentreren op het functionele gebruik van de media, dat wil zeggen in hoeverre en op welke wijze de ontvanger de media aanwendt om problemen op te lossen. De typologie van McQuail komt daarmee gedeeltelijk op losse schroeven te staan, maar biedt grosso modo toch een overzicht van mogelijkheden, die de ontvanger ter beschikking staan. Dit laatste drijft de intentionele voorlichter op gezette tijden naar precaire situaties, bijvoorbeeld als de behoefte aan verstrooiïng aanmerkelijk groter blijkt te zijn dan de behoefte aan informatie. Dat wordt nog erger als blijkt dat de ontvanger een afkeer heeft van, geen interesse toont of onverschillig is ten aanzien van het aanbod van de intentionele voorlichting. Van Woerkum noemt dit voorlich- 
1. Informatie

- bevrediging van nieuwsgierigheid en algemene interesse

- leren en zelfontwikkeling

- verkrijgen van een zekerheidsgevoel door kennis

- kennis vergaren over relevante gebeurtenissen en omstandigheden in de onmiddellijke omgeving, het maatschappelijk leven en de wereld.

- vraagbaak voor praktische zaken, menings- en besluitvorming.

2. Persoonlijke identiteit

- vinden van bevestiging van persoonlijke waarden

- vinden van modellen voor eigen gedrag

- identificatie met gewaardeerde anderen

- verkrijgen van inzicht in de eigen persoonlijkheid.

3. Integratie en sociale interactie

- verkrijgen van inzicht in de omstandigheden van anderen: sociale empathie

- identificatie met anderen en het krijgen van het gevoel erbij te horen

- vinden van bronnen voor gesprek en sociale interactie

- substitutie voor "levend gezelschap"

- hulp voor vormgeving van sociale rol

- mogelijkheid voor het vinden van aansluiting bij familie en vrienden en in het maatschappelijk leven.

4. Verstrooling en ontspanning

- vlucht voor of afleiding van problemen

- ontspanning

- beleving van intrinsiek cultureel of esthetisch plezier

- tijdverdrijf

- emotionele bevrijding/opwekking

- sexuele opwinding

Figur 4.3 Typologie van media-functies.

Bron: McQuail, 1983, pag. 82-83. 
ting tegen de verdrukking in, en zoekt aansluiting bij de "Uses en gratifications"-benadering om deze problematiek te lijf te gaan. Als mogelijke oplossing noemt hij bijvoorbeeld het zeer ruim en over lange tijd beschikbaar stellen van informatie. Regelmatige herhaling over een lange tijdsspanne worden ook door Maccoby en Solomon (1981) en Atkin (1981) aanbevolen om de ontvankelijkheid en betrokkenheid van het publiek te verhogen. Een andere mogelijkheid ziet Van Woerkum in transactie bijvoorbeeld het combineren van thema's of de voorlichting verpakken in amusement. De Way of Life-campagne is daar een treffend voorbeeld van (zie ook paragraaf 7.7). Ook het aanbieden van meer of het verhogen van de gratificaties behoort tot de mogelijkheden om het publiek te "winnen".

Onze geestdrift voor het aanwenden van de "uses and gratifications"benadering voor de planning van voorlichtingsactiviteiten, moeten we enigzins temperen door te wijzen op het feit dat deze benadering in de loop der tijd niet van kritiek verschoond is gebleven. Als belangrijkste bezwaren tegen de opvattingen van deze benadering gelden het ontbreken van een theoretische fundering, terminologische verwarring en het feit dat het uitgangspunt van deze functionalistische benadering , namelijk dat de bevrediging van de behoeften van individuele personen niet waardlevrij kan gebeuren. Voor gedetailleerde kritiek verwijzen we naar Stappers et al. (1990, pag. 163-168).

\subsection{De instrumentele bruikbaarheid van informatie}

In het voorafgaande is de typologie van McQuail aan de orde gesteld om te laten zien dat de ontvanger verschillende voorkeuren kan hebben om uit het brede massamediale aanbod een keuze te maken. Atkin (1973) postuleert dat de mens uit rationele overwegingen gebruik maakt van informatie. Hij maakt onderscheid tussen het zoeken naar informatie (information search) en het gebruik van informatie (information receptivity). De bruikbaarheid van informatie kent twee vormen, namelijk instrumentele bruikbaarheid en communicatieve bruikbaarheid. Communicatieve bruikbaarheid wordt als volgt omschreven: "To the extent that a message can provide the user with initial awareness about a new event or supplementary material on a topic he knows something about, the message has communicatory utility." (Atkin, 1972, pag. 190-191). Een boodschap heeft instrumentele bruikbaarheid, wanneer ze de ontvanger in staat stelt om 
een oplossing te vinden voor praktische problemen. Nauw verwant aan de instrumentele bruikbaarheid is de "Decisional utility" van Palmgreen et al. (1980), namelijk het zoeken naar informatie om een verantwoorde (persoonlijke/zakelijke) beslissing te kunnen nemen.

Het zoeken naar informatie, geconcipieerd als de reductie van onzekerheden, wordt gedomineerd door de instrumentele bruikbaarheid van de informatie. Mensen gaan op zoek naar informatie als zij een discrepantie percipiëren tussen de bestaande situatie en de gewenste situatie. Atkin ziet het opheffen van die discrepantie als een streven naar aanpassing aan de gewenste situatie. Hij onderscheidt vier basisvormen van aanpassingsvereisten, die een cognitief/affectief/gedragscontinuüm volgen.

1. Cognitieve aanpassing. De persoon wenst de wereld om hem heen te begrijpen en er betekenis aan te verlenen. In wezen neigt de persoon ertoe precieze formuleringen te geven van cognitieve oriëntaties op prikkels die potentieel of daadwerkelijk van invloed zijn op zijn welzijn. Het onzekerheidsgevoelen wil de persoon beheersen $\mathrm{cq}$. minimaliseren door middel van het uitbreiden van zijn cognities.

2. Affectieve aanpassing. Het individu is gehecht aan het toekennen van bepaalde waarden aan objecten, waarmee hij mogelijkerwijze geconfronteerd wordt. Een evaluatieve onzekerheid ten aanzien van bepaalde objecten leidt ertoe dat een behoefte ontstaat aan begeleidende informatie.

3. Gedragsaanpassing. De persoon komt tot de ontdekking dat hij kennis mist om bepaalde handelingen met succes te volbrengen. Naarmate het belang van de handeling door hem nadrukkelijker gepercipieerd wordt, zal hij onzekerheden trachten te elimineren. Aan deze behoefte tot eliminatie kan worden tegemoet gekomen door uitvoeringsinformatie (performance- information).

4. Defensieve aanpassing. De persoon streeft ernaar om de betekenis van een bepaalde cognitieve oriëntatie te toetsen. Post-cognitieve onzekerheid is afhankelijk van de grootte van de wens om pas opgeslagen of onlangs geleerde cognities te verifiëren. Op dezelfde wijze zal de persoon attitudes en besluiten toetsen op geschiktheid en correctheid (post-affectieve onzekerheid). Het streven naar reductie van deze onzekerheden wordt bereikt door het zoeken naar bevestigende informatie (reinforcement-information). Deze 
defensieve adaptie is zowel van toepassing op het niveau van cognitie en affectie als op dat van gedrag.

Het zoeken naar informatie, opgevat als handelingen om problemen op te lossen, is afgestemd op het streven naar nutsmaximalisatie op grond van een koster/baten-afweging en derhalve individueel bepaald. Met alle respect voor Atkin moeten we constateren dat de voorspellingswaarde van zijn model niet veel meer oplevert dan de selectiviteits-hypothese van Schramm (1953). Deze houdt in dat het individu kiest woor een bepaalde massamediale boodschap wanneer hij vermoedt dat de inhoud van de boodschap meer oplevert dan de moeite die men zich moet getroosten om ze te verwerven. Dit geldt uiteraard niet alleen vanuit fysiek opzicht maar vooral vanuit psychologisch oogpunt. Hierbij moeten we wel bedenken dat de selectiviteitshypothese gerelateerd dient te worden aan de moeite die het kost om andere boodschappen te verwerven. Er is immers voldoende aanbod. Van Cuilenburg (1987) spreekt, zoals elders reeds zijdelings is aangegeven, over "informatieblindgang": we worden overspoeld met informatie waarop niemand zit te wachten. Als verklaring voor de geringe pragmatiek van het groeiende informatie-aanbod noemt Van Cuilenburg: "Veel informatie heeft het karakter van een blindganger, is informatie zonder duidelijk informatief doel, is zowel naar strekking als naar adres ongericht en voorziet niet in vragen die bij de ontvanger leven."

Moschis (1980) hanteert het streven naar co-oriëntatie als handelingsconcept voor het zoeken naar informatie, dat wil zeggen het individu communiceert met anderen om zijn eigen (sociale) positie te handhaven en om een inschatting te kunnen maken van het gedrag van anderen. Cooriëntatie vervult hier als het ware een spiegelfunctie van de sociale omgeving. Sociale vergelijking in de zin van het vergelijken van opvattingen en attitudes met relevante anderen kan dan ook als motief voor het verwerven van informatie worden aangemerkt. Moschis noemt dit motief de sociale bruikbaarheid van informatie. Festinger (1954) stelt in zijn sociale vergelijkingstheorie dat mensen hun mening eerst toetsen aan objectieve maatstaven. Wanneer die ontbreken, zal men in de regel ziji/haar mening en bekwaamheden toetsen aan die van mensen van wie men veronderstelt dat ze ongeveer dezelfde mening zijn toegedaan of gelijke bekwaamheden hebben. Dit impliceert dat men zijn mening gaat vergelijken met meningen van andere mensen, waarbij het verschil in denken en 
handelen bij voorbaat niet te groot is. Indien de verschillen toch aanzienlijk zijn, zal men meer waarde hechten aan mensen die meer competenties bezitten. Schachter (1959) toonde in een experiment over affiliatie aan dat de verschillen niet te groot mogen zijn omdat dan de neiging om te vergelijken verdwijnt. Deze bevindingen sluiten nauw aan bij wat Van Cuilenburg en Noomen (1984) de assimilatie/contrasthypothese noemen, namelijk "dat de bias in de waarneming van de mediumboodschap afhankelijk is van de objectieve afstand die tussen de zender en de ontvanger bestaat."

Muskens en Van Oorschot (1985) gebruiken het begrip sociale referentie om het sociologische kader aan te geven van waaruit mensen geneigd zijn om informatie te zoeken. $\mathrm{Zij}$ onderscheiden een zestal dimensies van sociale referentie.

1. Sociale vergelijking. De mate van waardering van relevante anderen kan aanleiding zijn om op zoek te gaan naar informatie.

2. Aspiratie-niveau en prestatie-motivatie. Het is denkbaar dat mensen op zoek gaan naar informatie als men tot een bepaalde groep wil behoren of een bepaalde prestatie will leveren.

3. Relatieve deprivatie. Gevoelens van achterstelling kunnen ertoe leiden dat men zich geheel afsluit van mogelijke informatiebronnen, maar kunnen ook aanleiding zijn tot het streven naar betere levensomstandigheden, waardoor een actief zoekproces op gang komt.

4. Beleving van de eigen groep en (referentie)groepen kunnen aanleiding zijn om zich middels informatie nader te oriënteren. Muskens en Van Oorschot noemen hier als voorbeelden collectieve emancipatie, stereotypen, vooroordelen, discriminatie.

5. Acceptatie-cyclus van innovaties. Bepaalde groepen zullen snel een verandering accepteren; anderen doen dat geleidelijker. Alvorens men een verandering wil en kan accepteren zal men zich op de hoogte stellen van de consequenties.

6. Opinieleiderschap. In bepaalde groepen of segmenten van de samenleving treden opinieleiders op, die actief informatie distribueren of fungeren als vraagbaak voor leden van de groep. Zij behoeven actuele en gedegen informatie om hun rol te kunnen vervullen.

Naast sociale referentie plaatsen Muskens en Van Oorschot ook sociale ervaring in het sociologische kader. Hiermee willen ze aan- 
geven dat het doorlopen van processen en het volgen van bepaalde fasen om in een bepaalde situatie terecht te komen of een zekere status te verwerven, inzicht kan verschaffen in hoe men informatie verwerft en verwerkt. Met name kan de latente informatiebehoefte aan het licht komen.

\subsection{Het referentiemodel van het planmatig informatiezoekproces}

Muskens en Van Oorschot (1985) hebben het referentiemodel van het planmatig informatiezoekproces ontwikkeld naar aanleiding van het model van informatieconsumptiegedrag van Sepstrup (1980). Zij conceptualiseren een informatiebehoefte als aanwezig indien: "1. personen, vanuit hun cognities en evaluaties omtrent een situatie waarin zij verkeren, deze definiëren als problematisch; en 2 . als de personen zich een voorstelling maken van een gewenste situatie (ook deze voorstelling is afhankelijk van bestaande cognities en evalluaties van de persoon); en 3. als de personen van mening zijn dat gebruik van informatie hen in staat kan stellen de bestaande situatie in de gewenste om te zetten" (pag. 7-8). Het model gaat uit van een ervaren of gepercipieerd informatietekort. Het motief om dit ervaren informatietekort op te heffen wordt gedomineerd door het streven naar nutsmaximalisatie. Of de persoon daadwerkelijk overgaat tot het zoeken naar informatie, wordt volgens Sepstrup bepaald door een vijftal factoren, namelijk:

1. De omvang van de informatiebehoefte

2. Het belang van het onderwerp

3. De verwachte informatie via normaal mediagebruik

4. De mogelijkheid om verwachte informatie te verkrijgen buiten reeds in gebruik zijnde media om

5. De verwachte kosten voor het verkrijgen van informatie.

Ofschoon volgens Muskens en Van Oorschot het model praktisch goed bruikbaar blijkt, is het gepast om toch een paar kritische kanttekeningen ten aanzien van de assumpties te maken. Allereerst gaat het model er vanuit dat een persoon zelf het informatietekort kan registreren, dat wil zeggen de kloof tussen de bestaande situatie en de gewenste situatie. Deze moet op waarde geschat kunnen worden, om vervolgens te worden ervaren als zijnde "problematisch". Dit veronderstelt dat de persoon rationeel en consistent te werk gaat. Teneinde 


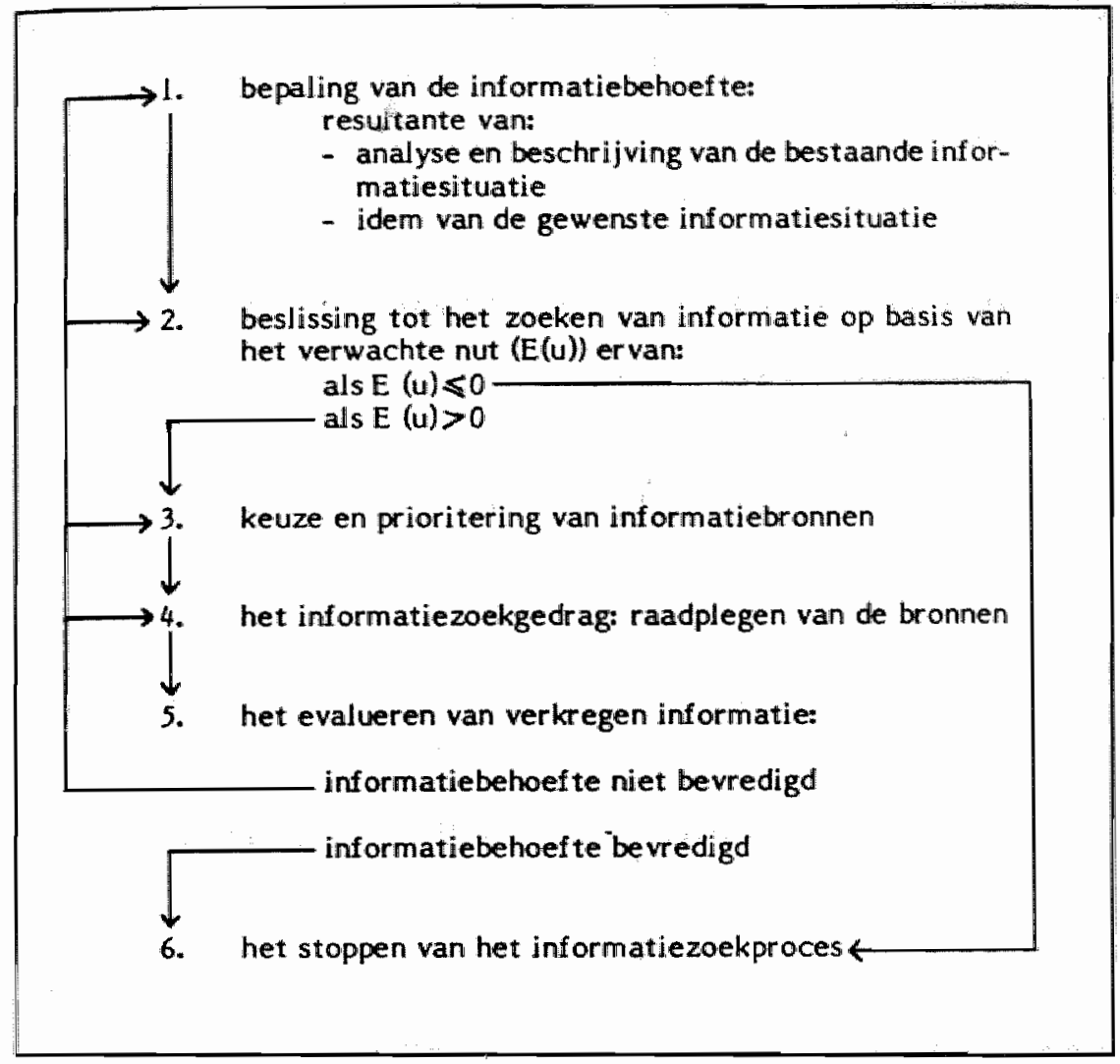

Figuur 4.4 Het referentiemodel van het planmatig informatiezoekproces. Bron: Muskens en Van Oorschot, 1985, pag. 23.

een inschatting te kunnen maken van het verwachte nut, dient men te beschikken over kennis van de relevante informatiebronnen. Het is maar zeer de vraag of een persoon bij zijn streven naar nutsmaximalisatie een prioriteitsvolgorde in de informatiebronnen kan aanbrengen. Een moeilijk toegankelijke bron zou dat weleens kunnen doorkruisen. Ons grootste bezwaar betreft het feit dat voorbij gegaan wordt aan de invloed en druk uit de directe sociale omgeving die het proces van informatiezoeken kunnen begunstigen of belemmeren. De waarde van dit model voor ons betoog is dat het inzicht verschaft in 
een aantal factoren dat de kans op het consumeren van informatie weergeeft.

\subsection{De Sense Making Approach}

Dervin $(1981,1983,1989)$ maakt schoon schip met de opvatting dat massamedia slechts beperkte effecten sorteren. Vooral de idee dat campagnes slechts resultaten laten zien in het kader van de ondersteuning van interpersoonlijke netwerken is haar een doorn in het oog. Haar bezwaren tegen de huidige audience research ("altijd van dezelfde snit en altijd volgens geijkte patronen") betreffen het feit dat de ontvangers als publiek altijd benaderd worden vanuit de optiek van de zender. De ontvanger wordt nog steeds bestudeerd in termen van het al dan niet opvolgen van communicatieboodschappen. $\mathrm{Zij}$ wil het publiek niet langer als een amorfe massa beschouwen en veronderstelt dat goed samengestelde boodschappen een grotere invloed hebben dan thans wordt aangenomen. $\mathrm{Zij}$ schetst een beeld van de ontvanger waarbij ze van de volgende impliciete assumpties uitgaat. De ontvanger is volgens haar uniek omdat er een aantal cognitieve processen optreedt tussen ontvangst en verwerking van informatie. Ze gaat er vanuit dat informatie het resultaat is van beperkte observatie; bijgevolg bestaat er geen absolute, accurate, isomorfistische relatie met de realiteit. Informatie dient daarom relativerend bekeken te worden: informatie heeft pas betekenis in de context van de ontvanger. Ze pleit ervoor om informatie niet op te vatten als een objectief "ding" (information-as-thing); informatie is geen materialistisch goed of substantie, dat van plaats naar plaats en van persoon tot persoon kan worden overgedragen met behoud van zijn eigenschappen. Informatie dient beschouwd te worden als construct (information-as-contruction). Dit vereist dat alle informatie begrepen moet worden als subjectief en als zodanig ook moet worden overgedragen. Informatie heeft alleen waarde voor de ontvanger in die mate dat ze geinterpreteerd, begrepen en toegepast kan worden door de ontvanger in zijn situatie, zijn tijd, plaats en perspectief. Bijzonder origineel is deze constatering van Dervin niet, want in de zeventiger jaren signaleerden Ball-Rokeach en De Fleur (1976) reeds: "... when people's social realities are entirely adequate.....media messages may have little or no alteration effects... In contrast, when people do not have social realities that provide adequate frameworks for under- 
standing, acting and escaping, and when audiences are dependent in these ways on media information received, such messages may have a number of alteration effects."

Dervin is echter van mening dat met name in het massacommunicatieve onderzoek onvoldoende rekening wordt gehouden met de bruikbaarheid van de informatie voor de ontwanger; onderzoekers en zenders zijn niet bedacht op de mogelijke discrepanties tussen realiteit en observatie. Kortom, als de situatie/context van tijd, plaats en perspectief van de zender niet gelijk is aan die van de ontvanger, gaat het mis. Wellicht is het interessant om dit probleem in te kaderen in het mechanisme van de "selective perception" (selectieve waarneming). In dit bestek heeft Dervin het aangedurfd om de knuppel in het hoenderhok te gooien. Mlustratief in dit verband is Stappers et al. (1983, 1990) als het gaat om de vraag waarom "selective exposure" steeds als belangrijkste verschijningsvorm van selectiviteit wordt genoemd in het massacommunicatieve onderzoek. Stappers stelt: "....het empirisch onderzoek heeft zich overwegend beziggehouden met selective exposure; de andere twee elementen zijn veel minder in onderzoek betrokken geweest. Dit verschil heeft vermoedelijk ook te maken met het feit dat selective perception en selective retention moeilijker te constateren zijn. Het is immers gemakkelijker om na te gaan of iemand een tv-programma wel of niet gezien heeft, dan om te bepalen wat hij van dat programma heeft overgenomen" (pag. 82). Wellicht is ons enthousiasme voor de visie van Dervin voor intentionele voorlichting hiermede verklaard.

Ten behoeve van campagnes introduceert zij de sense-making-approach, die - grosso modo - neerkomt op het beantwoorden van de volgende vier vragen die een voorlichter dient te betrekken bij het samenstellen van zijn boodschap:

1. Wanneer gebruiken mensen de boodschap?

2. Hoe flexibel is de boodschap voor gedrag?

3. Waar gebruiken de mensen de informatie voor?

4. Wat voorspelt/belooft de boodschap?

ad 1. Mensen zoeken informatie om de kloof te overbruggen die zij percipiëren om hun eigen wereld te begrijpen. Voor de voorlichtingsstrategie betekent dit dat men bij de doelgroep moet nagaan hoe men over bepaalde zaken denkt en welke oplossingen men zelf voorstaat. Dervin doet de suggestie om de bekende vijf $W$-vragen 
(Wie, Wat, Wanneer, Waarom en Op Welke wijze) toe te passen bij de beantwoording van deze eerste vraag.

ad 2. De boodschap moet niet gezien worden als een vast gegeven, er mag niet iets dwingends van uit gaan. Er dienen voldoende ruimte en mogelijkheden te worden geboden voor eigen initiatief. Om de flexibiliteit van de boodschap te kunnen achterhalen zijn "Time-line"interviews zeer geschikt. Aan de respondenten wordt gevraagd om stap voor stap aan te geven hoe zij van plan zijn om het veranderingsproces te doorlopen. Iedere stap wordt op een tijdlijn afgezet en beschouwd als een aparte situatie. Gedetailleerd wordt nagegaan hoe ieder fase wordt ervaren, welke barrières men ontmoet en welke kennis en vaardigheden men behoeft om het gehele proces te voltooien. Op deze wijze verwerft men ook inzicht in mogelijke gedragsalternatieven die mensen aan de dag kunnen leggen. Nadere analyse van deze gegevens kan de voorlichter gebruiken om zijn boodschap op maat te snijden.

ad 3. Er zijn verschillende manieren om informatie te gebruiken (zie mediafuncties McQuail). In de sense-making approach gaat het met name om het aanreiken van informatie die houvast biedt bij het oplossen van de eigen problemen.

ad 4. De inhoud van de boodschap dient gebaseerd te zijn op de perceptie van mensen in bepaalde situaties. Het is zaak om terdege rekening te houden met hoe mensen in een bepaalde situatie, vanuit hun eigen leef- en belevingswereld, een probleem proberen op te lossen. Het staat buiten kijf dat de inhoud relevant moet zijn in de optiek van de ontvanger en dat de inhoud geen valse verwachtingen mag oproepen.

Sinds 1972 is in een veertigtal studies gebruik gemaakt van deze benadering. Veelal vonden ze hun toepassing op het gebied van de gezondheidszorg. Op de keper beschouwd is de sense-making-approach een variant op de Use and gratifications-benadering. De reden dat wij deze benadering expliciet aan de orde stellen is niet alleen de originele, pragmatische aanpak, maar vooral de nadrukkelijke aandacht voor het samenstellen van de boodschap. In 1989 concludeert Dervin dat de toepassing van deze benadering succesrijk is, als aan de volgende punten voldaan wordt: 
a. Het publiek moet bereikt worden op het moment dat deze de informatie nodig heeft.

b. Mensen zullen eerst hun eigen eigen cognitieve bronnen en ervaringen benutten; daarna zullen ze bronnen raadplegen, die zo direct mogelijk in hun nabijheid zijn.

c. Bruikbare informatie wordt niet beoordeeld op basis van deskundigheid en geloofwaardigheid maar veeleer in termen van hoe de informatie bijdraagt aan de oplossing van het eigen probleem. Indien mocht blijken dat het probleem niet opgelost wordt, zullen zij de deskundigheid en betrouwbaarheid in hun gebruik betrekken.

d. Mensen zijn (intrinsiek) geïnteresseerd in tegenstrijdige gezichtspunten; zij stellen het op prijs kennis te nemen van motieven of redenen en oorzaken van gebeurtenissen. Deze "waarom" vragen worden door het publiek als zeer belangrijk ervaren.

e. Het zoeken naar en gebruik van informatie kan het best voorspeld worden op basis van gegevens over hoe de doelpopulatie de situatie inschat, de beperkingen en verplichtingen, die ze percipiëren, het verschil tussen de oorspronkelijke en gewenste situatie en de wijze waarop ze zelf het probleem willen oplossen. Er dient dus meer aandlacht te zijn voor situationele (tijd/ruimte) variabelen dan persoonlijke/demografische variabelen.

Volledigheidshalve wijzen we erop dat Dervin reeds in 1983 haar concept over informatie wijzigde in "information as observer construct" en "information as user construct". Het laatste construct gaat er vanuit dat mensen in bepaalde situaties bepaalde soorten informatie nodig hebben die rekening houdt met probleemdefinities, interessen, ervaringen, belevingswereld, etc..

\subsection{Slotbeschouwing}

Intentionele voorlichting gaat niet uit van de behoefte aan voorlichting, maar dient daar wel nadrukkelijk aansluiting bij te vinden. Deze aansluiting wordt alleen maar gevonden wanneer men weet hoe mensen met de nieuwe informatie omgaan, hoe het publiek discrepanties met bestaande kennis ervaart en op welke wijze de informatie aangeboden dient te worden. Voorts is het van belang om te weten hoe het in de boodschap gesignaleerde probleem door de ontvangers 
gepercipieerd wordt en welke knelpunten een mogelijke verandering in de weg staan. Kortom, de voorlichter moet in de huid van de ontvanger kruipen vooraleer hij plannen gaat ontwikkelen voor een veranderingsstrategie. Voorlichters gaan vaak in de fout door bij een gesignaleerd probleem onmiddellijk te reageren met een grote hoeveelheid informatie die alleen gericht is op uitbreiding van kennis van het probleem. Zo weet bijvoorbeeld iedere zonderling dat alcoholgebruik in het verkeer de rijvaardigheid kan beïnvoeden met mogelijk een fatalle afloop. Wat mensen niet weten, is hoe men de sociale druk kan weerstaan om alcohol te drinken, welke vaardigheden daarvoor nodig zijn, etc. Kortom, het gaat in veel gevallen om het verstrekken van die informatie die relevant is voor het oplossen van het probleem en die zonder al te veel moeilijke manoeuvres is toe te passen in de alledaagse situatie. Duidelijk zal zijn dat het bij intentionele voorlichting vooral gaat om het motivationele aspect van het menselijke gedrag. In hoofdstuk drie hebben we daar uitgebreid bij stilgestaan.

In dit hoofdstuk hebben we willen beklemtonen dat het beinvloeden van gedrag in een gewenste richting bepaald geen sinecure is. Bij intentionele voorlichting zal men de ontvanger moeten benaderen als een kritische en rationele partner, die doorgaans kan putten uit verschillende, soms tegenstrijdige informatiebronnen. Ontvangers leven niet in een vacuüm; hun belangen, verwachtingen en gedrag zijn vervlochten in sociale netwerken. Deze willekeurige greep uit factoren die van invloed zijn op een beïnloedingspoging, hebben vergaande consequenties voor de samenstelling van de boodschap en de te ontwikkelen strategie.

Onze conclusie komt nagenoeg overeen met de inzichten van Bosman et al. (1989), die een multidisciplinair theoretisch referentiekader voor empirisch onderzoek naar de vraag naar voorlichting hebben ontworpen. Zij postuleren dat, wanneer mensen de keuze hebben uit gedragsalternatieven, de voorkeur uitgaat naar dat gedrag waaraan de meest gunstige consequenties verbonden zijn. Bij de verwachte/gepercipieerde waarde van gedrag zijn vier factoren essentieel, namelijk (a.) de beschikbare gedragsalternatieven gekoppeld aan (b.) de consequenties, die aan de verschillende gedragsalternatieven verbonden zijn en (c.) de inschatting van het optreden van die consequenties vermenigvuldigd met (d.) de waardering voor die consequenties. Voor ons betoog zijn met name de consequenties van gedrag en de gedragsalternatieven interessant. Voor de praktijk van de voorlichting impliceert dit dat men nadrukkelijk moet ingaan op de voor- en nadelen 
die aan bepaalde gedragingen gekoppeld zijn. Indien de voorlichter het publiek opzettelijk confronteert met een probleemsituatie, is het zinvol om na te gaan of er voor de ontvanger ook redelijke/acceptabele gedragsalternatieven zijn. Zo zou de Aids-campagne "Veilig Vrijen" geen zin hebben, als men niet het condoom als gedragsalternatief zou propageren. $\mathrm{Om}$ te achterhalen welke consequenties men in de voorlichtingsboodschap zou kunnen betrekken, welke gedragsalternatieven als acceptabel worden gezien, hoe kansen en waarderingen moeten worden ingeschat, is de sense-making-approach van Dervin geschikt. Deze benadering schenkt zowel aandacht aan persoonlijke/demografische variabelen als aan contextuele variabelen ten aanzien van het gebruik van informatie. Met name deze laatste variabelen verdienen zowel in onderzoek als in de praktijk meer aandacht. 



\section{Hoofdstuk 5 Modellen van intentionele voorlichting}

\subsection{Inleiding}

5.2 Het informatieprocesmodel

5.3 De theoretische fundering van de "communication/persuasionmatrix ${ }^{\text {m }}$

5.4 Het model van gedragsverandering door voorlichting

5.5 Het Elaboration-Likelihoodmodel

5.6 Het integratiemodel

5.7 De relatie attitude - gedrag

5.8 Slotbeschouwing

\subsection{Inleiding}

Zoals in het voorafgaande betoogd is, berust intentionele voorlichting op de premisse van vrijwillige verandering. Dit impliceert dat de voorlichter alle zeilen moet bijzetten om zijn publiek te motiveren om conform zijn intentie te handelen. Om veranderingen in cognities, attitudes of gedrag te bewerkstelligen kan niet volstaan worden met incidentele informatie-overdracht. Het aanbod van informatie dient continu en systematisch te verlopen, indien men een permanent effect wenst te bereiken. Het streven naar duurzame gedragsverandering verloopt via internalisatie dat wil zeggen de ontvanger accepteert de informatie op een zodanige manier, dat permanente integratie in opvattingen, houdingen en handelen plaatsvindt. Beïnvloedingsprocessen die leiden tot internalisatie, verlopen doorgaans volgens een 
drietal fasen, namelijk motivatie, oriëntatie en acceptatie. In dit hoofdstuk zullen we een aantal courante modellen bespreken die betrekking hebben op het verwerken van informatie en nader ingaan op factoren die in de afzonderlijke fasen van het beinvloedingsproces een rol van betekenis spelen.

\subsection{Het informatieprocesmodel}

Het oorspronkelijke informatieprocesmodel, waaraan de namen van Laswell, Lazarsfeld, Lewin en Hovland verbonden zijn, stamt uit de vijftiger jaren. McGuire (1969) heeft dit model nader uitgewerkt en in zijn "persuasionmatrix" opgenomen. Op de horizontale lijn van de matrix van McGuire staan factoren die afzonderlijk of in combinatie de onafhankelijke variabelen vormen, namelijk bron, boodschap, kanaal, ontvanger en bestemming. Op de verticale lijn staan de afhankelijke variabelen, die in zes stappen het stochastisch proces van gedragsverandering weergeven. Het proces vangt aan met de blootstelling aan de informatie. Dan volgt het aandacht schenken aan de boodschap en zich bewust worden van de inhoud ervan. De derde stap betreft het begrijpen van de boodschap zodanig dat een vermeerdering van kennis ontstaat. Vervolgens dient de nieuwe informatie overwogen te worden, hetgeen moet resulteren in veranderingen in opvattingen en attitudes. De voorlaatste stap betreft de persistentie van de attitudeverandering, die tenslotte moet leiden tot verandering van gedrag.

Het idee achter het informatieprocesmodel is dat veranderingen in cognities leiden tot veranderingen in affecties, die weer overgaan in conatieve veranderingen. McGuire beschrijft het model in probabilistische zin, dat will zeggen de opeenvolgende fasen gaan niet automatisch in elkaar over, maar dienen als prealabele voorwaarden vooraleer men de volgende fase met succes kan doorlopen. Voordat bijvoorbeeld sprake is van bewustwording, zal eerst blootstelling (ontvangst van de boodschap) moeten plaatsvinden. Deze leerhiërarchie (cognitief-affectief-conatief) is volgens Ray (1973) niet de enige mogelijkheid als het om beïnvloeden via de massamedia gaat. Ook andere volgordes, bijvoorbeeld cognitief-conatief-affectief worden in de literatuur beschreven (Flay, DiTecco en Schlegel, 1980; Kline en Pavlik, 1981; Van Raaij, 1984). Ook Chaiken en Stangor (1987) wijzen erop dat attitudeverandering pas kan optreden, indien gedragsverandering 
al heeft plaatsgevonden. Met name refereren zij aan de zelfperceptietheorie van Bem (1972) en Fazio en Zanna (1981) en de dissonantietheorie van Festinger (1957). Volledigheidshalve is de opmerking gepast dat de epigonen van de leerhiërarchie zich uiteraard bewust zijn van het feit dat er ook andere hiërarchieèn bestaan, maar zij achten deze minder geschikt voor voorlichting. In de marketingcommunicatie worden de andere hiërarchieën meer toegepast. In paragraaf 5.7 komen we nader op deze materie terug.

In de loop der tijd heeft McGuire het model verbeterd en aangepast aan nieuwe inzichten afkomstig uit studies over attitudeverandering. In het meest recente model (1985) heeft uitbreiding naar twaalf stappen plaatsgevonden. De eerste vier fasen bestrijken het cognitieve domein namelijk blootstelling aan de informatie (stap 1), aandacht krijgen voor de boodschap (stap 2), vervolgens interesse kweken voor het onderwerp (stap 3) en tenslotte het begrijpen van de inhoud (stap 4).

De volgende stappen hebben betrekking op het affectieve domein en zijn te beschouwen als het verwerken van de ontvangen en begrepen informatie. In stap $5 \mathrm{zal}$ de nieuwe informatie getoetst worden aan de bestaande voorkennis. Deze afweging kan ertoe leiden dat de ontvanger vaardigheden moet verwerven/aanleren om de gewenste handelingen uit te voeren (stap 6). Vervolgens zal hij de nieuwe informatie aanvaarden en zal attitude-verandering optreden (stap 7). Om de nieuw gevormde cognities te bestendigen zal hij deze opslaan in zijn geheugen (stap 8). Indien de ontvanger de informatie nodig heeft, moet deze geactualiseerd worden uit het geheugen (stap 9). Vervolgens dient een beslissing genomen te worden op basis van argumenten (stap 10). Dan volgt uitvoering van het gedrag, dat will zeggen handelen conform het genomen besluit (stap 11). Tenslotte moet het gedrag verankerd worden in die zin dat de verandering geconsolideerd wordt in gedragsbehoud (stap 12). Schematisch wordt het model in figuur 5.1 in beeld gebracht.

Het is goed te bedenken dat McGuire er vanuit gaat dat het proces alleen doorlopen kan worden als aan de successievelijke stappen is voldaan; voltooiing van de ene stap is een voorwaarde voor de waarschijnlijkheid van de opvolging van de aangrenzende fase. 
ORJENTTATIE-FASE

1. Blootstelling aan informatie ontvangst

2 Aandacht voor boodschap

3. Interesse voor onderwerp

4. Begrijpen van de inhoud

5. Toetsen aan voorkennis

6. Verwerven van vaardigheden

ACCEPTATIE-FASE

7. Aanvaarden - attitudeverandering

8. Opslaan in het geheugen

9. Actualiseren van de informatie

10. Beslissing nemen op basis van argumenten

INTEGRATIE-FASE

11. Handelen conform het besluit

12. Gedragsbehoud

Figuur 5.1 De fasen in het informatieprocesmodel.

Verplanken (1989) heeft, als voorbeeld om aan te tonen hoe moeilijk het is om alle fasen te doorlopen, de kans berekend op het voltooien van de 12 stappen in het voorlichtingsproces. Hij veronderstelt dat alle omstandigheden in een bepaalde voorlichtingscontext uitzonderlijk gunstig moeten zijn, dat wil zeggen een kans van .90 voor elke te voltooien stap. De kans op ontvankelijkheid van .90 is extreem hoog. De kans op voltooiing van de eerste twee stappen is $.90^{2}=.81$ enz.. De kans na de eerste vier fasen is dan .66. De kans op een attitudeverandering na zeven fasen is nog geen fifty-fifty (.48). De kans op het 
voltooien van het hele proces is slechts .28 . Onderstaande figuur (5.2) laat in 3 hypothetische curven de kansen zien op het bereiken van ellke fase bij een gemiddelde kans van $.90, .80, .70$.

Indien we geloof hechten aan de optimische uitgangspunten van Verplanken, dan nog zijn de resultaten, om het maar eens zachtjes uit te drukken, weinig hoopgevend.

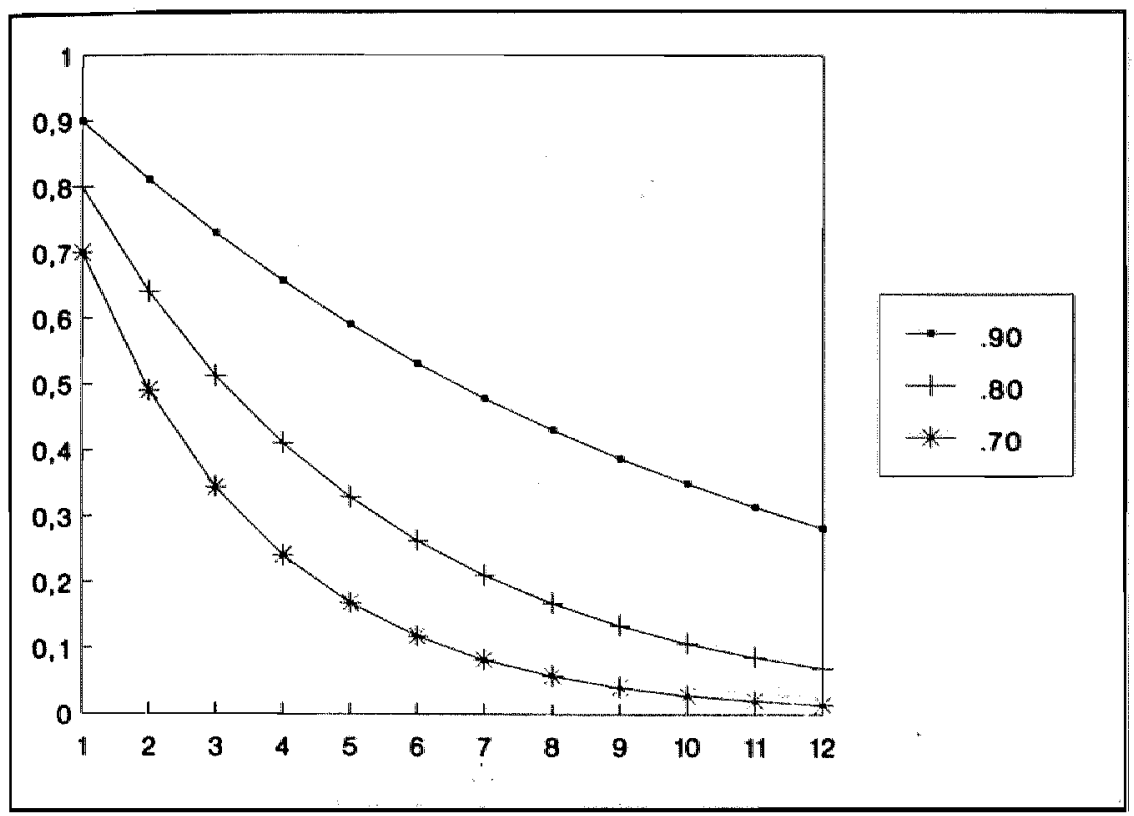

Figuur 5.2 Kansen op het voltooien van de twaalf stappen bij een gemiddelde kans van .90, .80, .70.

Bron: Verplanken, 1989, pag. 16.

Ter voorkoming van verwarring moeten we erop wijzen dat de matrix van McGuire niet uitsluitend ontworpen is om het proces van massamediale beinvloeding weer te geven. Ook andere vormen van beïnvloeding van attitudes en gedrag (bijvoorbeeld groepsdiscussie, conformiteitssituaties zoals imitatie en modelling, indoctrinatie) zijn met behulp van dit conceptuele raamwerk te beschrijven. In de volgende paragraaf zullen we aandacht schenken aan de achtergron- 
den van het informatieprocesmodel en zullen we ons nader verdiepen in de fundamenten waarop het model gebaseerd is. We benaderen deze theoretische fundering vanuit de relevantie voor massamediale voorlichting.

\subsection{De theoretische fundering van de "communication/persuasion- matrix"}

In de vorige paragraaf zijn de onafhankelijke variabelen behandeld van de communicatiematrix van McGuire. Daarin wordt systematisch aangegeven welke stappen doorlopen moeten worden, wil voorlichting effecten sorteren op het cognitief-, affectief- en gedragsniveau. In het nu volgende zullen we proberen aan te geven welke dynamische krachten achter het verwerken van informatie schuilgaan. We baseren ons hierbij op de theorieën van persuasieve communicatie, zoals die door McGuire (1981) beschreven zijn. McGuire stelt dat er geen omvattende theorie is die kan verklaren waarom de ene campagne wel succes heeft en de andere faalt. Wel is er een aantal theorieën dat een bepaald aspect van de motivatie tot informatieverwerking kan blootleggen en verklaren. McGuire heeft een overzicht samengesteld van 16 theorieèn die elk een deelaspect van de motivatie verklaren. Deze theorieèn heeft hij, zoals onderstaand figuur (5.3) laat zien, verdeeld over vier bipolaire dimensies, waarbij elke dimensie is opgebouwd uit tegenstellingen binnen een bepaald motivatie-aspect. Van de vier dimensies gaan de eerste twee (op de horizontale lijn) over krachten die de menselijke handeling in gang zetten, terwijl de derde en vierde (langs de verticale lijn) te maken hebben met de beëindiging van de handeling. In de eerste dimensie wordt onderscheid aangebracht tussen stabiliteits- en groeitheorieên. In de stabiliteitstheorieën wordt de mens gezien als iemand die ernaar streeft het huidige psychologische evenwicht te handhaven. In de groeitheorieën daarentegen wordt de mens opgevat als een wezen dat naar steeds hogere niveaus van zelfactualisatie streeft. In de groeitheorieën is het streven dus niet gericht op het behouden of verkrijgen van een psychologisch evenwicht ${ }_{j}$ maar wordt de mens aangezet tot actie door de behoefte om te groeien. Zowel in de stabiliteits- als in de groeidimensie wordt weer een onderverdeling aangebracht in actieve en reactieve conceptualisaties ( $2 \mathrm{e}$ dimensie). De actieve theorieèn gaan ervan uit dat menselijke gedragingen gestimuleerd worden door 
interne krachten, terwijl volgens de reactieve theorieen menselijk gedrag wordt opgewekt door externe krachten uit de omgeving.

De derde dimensie verdeelt de theorieën in een cognitieve en een affectieve component. De vierde dimensie verdeelt de cognitieve en affectieve theorieën enerzijds in theorieën die stellen dat actie ophoudt zodra het individu een bevredigende oplossing heeft bereikt in termen van interne relaties binnen de eigen persoonlijkheid, en anderzijds theorieên waarin de bevredigende toestand tot stand wordt gebracht door de externe relaties tussen de persoon en diens omgeving. We kunnen ons niet helemaal aan de indruk onttrekken dat de compositie van het overzicht toch ietwat gekunsteld aandoet.

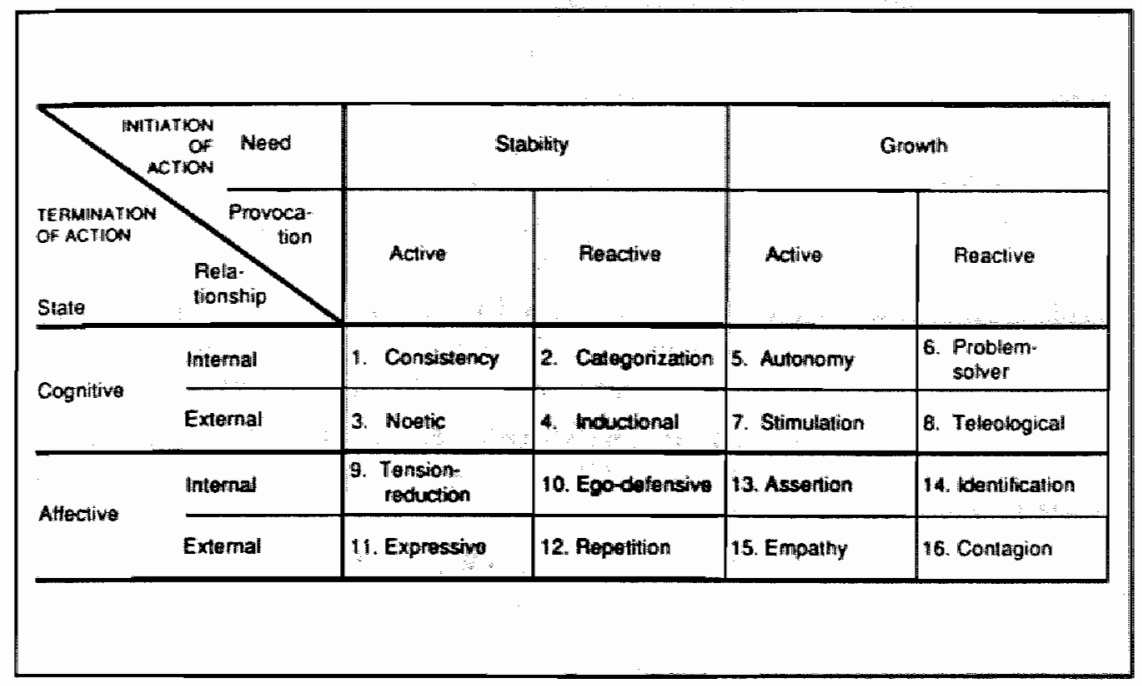

Figur 5.3 Overzicht Dynamische theorieèn van McGuire. Bron: McGuire, 1989, pag. 54.

In het navolgende zullen we kort en bondig nadere tekst en uitleg geven bij de theorieën die McGuire in zijn overzicht vervat heeft. We verdelen ze in navolging van McGuire in vier groepen: 
a. de cognitieve stabiliteitstheorieën

b. de cognitieve groeitheorieën

c. de affectieve stabiliteitstheorieèn

d. de affectieve groeitheorieën

We vangen onze bespreking van de theorieën aan in de linker bovenhoek van figuur 5.3 .

\section{Consistentietheorieèn}

Tot deze theorieen behoren o.a. de balans-theorie, de dissonantietheorie, de congruiteitstheorie, de symmetrietheorie, McGuire (1985, pag. 296) beschrijft in deze categorie theorieën de persoon als: "... striving to maintain a connected and coherent cognitive system, as instigated to action in order to reduce any imbalance that occurs among his or her perceptions, memories, feelings, needs, behavior, role commitments, cultural norms, etc.". Deze theorieën, die in de jaren zestig populair waren in het persuasion-onderzoek, hebben gemeenschappelijk dat ze beliefs, attitudes en handelingen van de mens in onderlinge samenhang bestuderen in diens streven naar de handhaving van een hoge graad van interne cohesie. Voor de voorlichting heeft dit geresulteerd in de notie dat attitudeverandering eerder volgt op dan vooraf gaat aan gedragsverandering (ter rechtvaardiging van gedrag). Ook hebben zij aan het licht gebracht dat voorlichting geringe invloed heeft op zaken die niet expliciet in de voorlichting aan de orde zijn gesteld, maar wel gerelateerd zijn aan het expliciete onderwerp. Vanuit deze theoretische invalshoek werd ook de zogenaamd "Socratische methode" geïntroduceerd: meningen en gedrag worden veranderd door de persoon gevoelig te maken voor zijn inconsistenties, door middel van vragen die de inconsistente houdingen bij twee of meer gerelateerde zaken gelijktijdig aan het licht brengen. Dit resulteert in een verandering van beliefs in de richting van het gewenste doel. Voorbeeld: Bent u voor een schoner milieu ? Gooit u dan uw oude batterijen in de de vuilnisbak? De socratische-methode geeft dus geen aansporingen voor het gewenste gedrag, maar maakt door middel van directe vragen duidelijk hoe inconsistent bepaalde handelingen zijn. 
2. Categorisatietheorieën

De categorisatietheorieën gaan er vanuit dat mensen bedolven worden onder een niet aflatende stroom van informatie vanuit de externe omgeving en geactiveerd worden door interne stimuli (bijvoorbeeld reeds aanwezige kennis die geactualiseerd wordt). Wanhopig proberen de mensen de informatie te verwerken door deze op te slaan in bestaande cognitieve categorieën. $\mathrm{Na}$ verloop van tijd is het echter niet meer mogelijk om nieuwe feiten binnen de heersende psychologische structuur in te passen, omdat zij in tegenspraak raken met de bestaande veronderstellingen. Dan volgt als het ware een herwaardering/afweging van oude versus nieuwe informatie. Voor de voorlichting betekent dit dat de boodschap niet gericht moet worden op het veranderen van de reacties van de mensen op het ervaren van een bepaald symptoom, maar op het veranderen van hun waarnemingen hoe ze het symptoom zien. Bij deze theorieën gaat het dus niet direct om verandering van attitude en gedrag maar allereerst om de verandering van de perceptie. Zodra veranderingen in perceptie optreden, kan een volgende stap genomen worden in de richting van gedragsverandering.

\section{Noëtische theorieën}

De noëtische theorieën, waartoe de attributietheorie en de "locus of control"-theorie gerekend worden, leggen de nadruk op de poging van mensen om de consequenties van hun gedrag vast te stellen en op grond daarvan hun gedrag te bepalen. Het gaat daarbij niet alleen om feitelijk gedrag, maar ook om de verwachtingen ten aanzien van de resultaten van gedrag in de toekomst. Mensen zoeken naar een reden om hun eigen succes of falen te kunnen verklaren. Binnen de "locus of control" (Rotter, 1966; Wallston and Wallston, 1978) kunnen drie dimensies onderscheiden worden, namelijk (a.) "internal locus of control": mensen hebben de overtuiging dat gebeurtenissen die hen overkomen in belangrijke mate toe te schrijven zijn aan eigen gedragingen; (b.) "powerfull others": gebeurtenissen die mensen overkomen, schrijft men toe aan de invloed van anderen; (c.) "external control": gebeurtenissen zijn toe te schrijven aan zaken als "het lot", "toeval", "geluk" of andere externe krachten.

Bij voorlichtingscampagnes benadrukken de aanhangers van deze groep theorieën het belang van een structuur in de boodschap 
waarbinnen systematisch naar een oplossing wordt toegewerkt. Het is noodzakelijk dat de voorlichting een context geeft waarin de aanbevelingen zinnig zijn zodanig dat het publiek deze aanvaardt. De mate van acceptatie wordt verhoogd, als de boodschap een realistische aanvulling geeft op onderwerpen waarover de mensen zich anders onzeker zouden voelen. In dit verband kan gewezen worden op de resultaten van herattributie-onderzoek; door het veranderen of aanleren van een bepaalde attributie treedt er verschil op in gedragsconsequenties.

Halfens (1985) stelt dat bij het beinvloeden van (de intentie tot) gedrag men vooral de nadruk dient te leggen op bekrachtiging, dat wil zeggen het versterken van de samenhang tussen een prikkel (stimulus) en een (nieuwe) reactierespons. Voorts geeft hij aan dat het "locus of control"-concept goed bruikbaar is in situaties die nieuw of ambigue zijn.

\section{Inductieve theorieën}

Deze theorieën vertonen een gelijkenis met de noëtische theorieën; ze richten zich op de pogingen van de mens om ervaringen te verklaren. Maar in tegenstelling tot de noëtische theorieën gaan de inductieve theorieën er vanuit dat de mens de zaken overpeinst als reactie op externe druk in plaats van als gevolg van een innerlijke behoefte om meer te weten. Deze theorieën beschrijven mensen als personen die door het leven gaan zonder al te veel na te denken totdat gebeurtenissen of andere mensen hen uitdagen rekenschap te geven van wat er gebeurt. Mensen gaan dan interpreteren wat er gebeurt door middel van het observeren van eigen gedrag (Bem, 1972) of door middel van het vergelijken van hun eigen gedrag met dat van anderen (vgl. Social comparison theory van Festinger). Fauconnier (1981) stelt dat de mens in de communicatietheorieën doorgaans vrij passief wordt afgeschilderd; de communicatie-actor wordt in zijn gedragingen sterk bepaald door de "ander" of door zijn omgeving in het algemeen en zijn eigen inbreng blijft in het vage. De fenomenologie van Schutz en het symbolisch interactionisme (Mead, Blumer, Goffman et al.) daarentegen leggen de nadruk op de actieve mens die zijn omgeving meebepaalt. De fenomenologie hanteert een intersubjectieve opvatting over communicatie. Het participeren aan de sociale werkelijkheid vindt plaats door intersubjectiviteit: de mens gelooft dat anderen de wereld ervaren zoals hijzelf doet en dat hij in staat is zich andermans 
standpunten en motieven eigen te maken. Communicatie is pas mogelijk wanneer de informatie voor de communicatie-actoren dezelfde betekenis heeft en wanneer de manieren van interpreteren grotendeels samenvallen.

Fauconnier (1981) beziet het symbolisch interactionisme als een opvatting waarin: "... menselijke wezens ageren tegenover hun omgeving (objecten, personen, enz.) op grond van de betekenissen die deze omgeving voor hen heeft (sociaal handelen); deze betekenissen zijn rechtstreeks het gevolg van de sociale interactie die mensen met anderen hebben; deze betekenissen worden gecreëerd, behouden en gewijzigd door een interpretatief proces dat zich bij de persoon afspeelt wanneer hij zijn omgeving tegemoet treedt. Hij schept zijn omgeving en zijn "zelf" op hetzelfde ogenblik en hij is dus geen product van ervaringen uit het verleden of van stimuli uit de omgeving..." (Fauconnier 1981, pag. 173).

Voor voorlichtingscampagnes hebben deze theorieën als consequentie dat men eerst een situatie moet creëren waarin mensen een voorbeeldfunctie kunnen ontdekken, die voldoende aangrijpingspunten biedt voor de ontvanger om het voorbeeldgedrag over te nemen.

\section{Autonomische theorieën}

Deze theorieën gaan uit van de menselijke behoefte aan vrijheid en controle (beheersing) over eigen bestemming en omgeving. De sociaalpsychologische theorieën van Brehmn (reactance theorie, 1974), Lazarus (stress-theorie, 1980) en Steiner en Levinson (1978) wijzen erop dat mensen hun opvatting en gedrag veranderen in de richting van het streven naar autonomie, indien blijkt dat de behoefte aan beheersbaarheid wordt gefrustreerd. De voorlichter moet hieruit de wijze les trekken dat voorlichting waarbij mensen een gedeelte van hun persoonlijke vrijheid moeten inleveren, bij voorbaat tot mislukken gedoemd is. In dit verband is bijvoorbeeld het terugdringen van het autogebruik omwille van een schoner milieu voor de voorlichter een hachelijke zaak. McGuire suggereert om in de voorlichtingsboodschap het idee te opperen dat de persoonlijke vrijheid wordt uitgebreid. Als mensen het idee wordt gegeven dat ze in alle vrijheid kunnen kiezen, zullen ze tevreden zijn met hun besluit; ze zijn ontevreden als ze het gevoel hebben dat een bepaald gedrag aan hen opgelegd wordt, ook al zouden ze er in een ander geval zelf voor gekozen hebben. 


\section{Probleem-oplossende theorieën}

Deze theorieën bezien de mens als iemand die, wanneer hij geconfronteerd wordt met verschillende situaties, deze definieert als een probleem dat met het grootst mogelijke resultaat en met de minste moeite opgelost dient te worden.

In zijn streven naar voldoening en beloning zal de mens zijn probleemoplossende vaardigheden vergroten zodat uit zijn gedrag het maximale nut wordt gehaald. De "Expectancy $x$ Values"-theorie van Fishbein en Ajzen (1980) is een voorbeeld van deze groep theorieën. In de voorlichtingsboodschap zou men dus moeten aangeven dat met een minimum aan inspanning een maximaal resultaat bereikt kan worden. Ook zou men moeten aangeven dat bepaalde barrières die het gewenste gedrag mogelijk zouden kunnen blokkeren, geslecht kunnen worden met het aanleren of oefenen van bepaalde vaardigheden.

\section{Stimulatietheorieën}

Deze theorieën beweren dat de mens gestimuleerd wordt door honger, spel en opwinding/sensatie. De opwinding/sensatie komt voort uit het streven van de mens naar een zo ruim mogelijke ervaring. Voor voorlichting impliceert deze theorie dat de boodschap zowel qua inhoud als qua vorm veel onverwachte en nieuwe elementen moet bevatten. In ieder geval moet vermeden worden dat de boodschap de suggestie wekt dat pogingen om de eigen ervarings- en belevingswereld uit te breiden aan banden worden gelegd. Een negatieve of verbodsbenadering is dus uit den boze. Interessant in dit verband is het concept "risico homeostase" van Wilde (1982): mensen passen hun gedrag aan aan het risico dat ze zelf acceptabel vinden (target level of risk). Bijvoorbeeld mensen die hun eigen competentie en vaardigheden hoog inschatten, zullen de risicosituatie laag inschatten. Volgens Wilde is het niet zinvol om de waargenomen risico's te manipuleren, maar mensen te motiveren tot het verlagen van het streefniveau van risico. Voorlichting kan in deze effectief zijn als blijkt dat een bepaalde populatie stelselmatig het risico te laag inschat. 


\section{Telleologische theorieën}

Deze theorieen bezien de mens als een actief wezen dat een zinvol verband zoekt tussen de delen onderling, aismede tussen de delen en het geheel. De mens heeft een beeld opgebouwd van zijn voorkeurssituatie en probeert daar zoveel mogelijk aan tegemoet te komen. Dit impliceert dat mensen selectief te werk gaan bij de waarneming en de vorming van indrukken en opvattingen. Sommige waarnemingen krijgen extra veel aandacht; andere worden (nog) niet eens opgemerkt. De waarnemingen worden geordend opgeslagen in het geheugen. Er worden bijvoorbeeld relaties gelegd tussen de waargenomen stimuli, andere worden gegroepeerd opgeslagen. De meest voorkomende relatie in de waarnemening is de oorzaak-gevolg relatie. Een andere manier van ordening van waarnemingen is het consistentie-principe: stimuli uit de sociale omgeving worden verenigbaar, passend, consistent gemaakt met bestaande opvattingen, houdingen en gedrag (zie ook paragraaf 3.4). Aansluitend op het consistentieprincipe willen we nog de aandacht vestigen op de betrokkenheid van de waarnemer bij de informatie. Algemeen wordt aangenomen dat, naarmate mensen meer geïnteresseerd en meer betrokken bij de boodschap zijn, zij de informatie gemakkelijker kunnen verwerven en verwerken. Tot slot willen we nog wijzen op het feit dat mensen hun eigen werkelijkheid construeren met behulp van schema's, dat wil zeggen georganiseerde cognitieve structuren (zie hiervoor Koomen, 1988).

\section{Spanningsreductietheorieën}

Het concept achter deze theorieën is dat de mens streeft naar affectieve stabiliteit. Het streven is gericht op een "ideale toestand van het organisme", waarin alle behoeften bevredigd zijn. Dit is de kern van de Nirwana-theorie: het bereiken van een toestand van prikkelloosheid. Deze opvatting sluit nauw aan bij de ideeën van Freud: een behoefte vraagt om bevrediging. Wanneer de bevrediging bereikt is, is de behoefte niet meer aanwezig. Het essentiële van een behoefte is dat ze er is om opgeheven te worden. Uit onderzoek van Leventhal et al. (1980, 1984) bleek dat mensen emaar streven de motivatieprikkeling te verminderen ofwel door het probleem zelf ter hand te nemen ofwel door het te vermijden. Voorlichting dient derhalve zodanig ontworpen te worden dat de spanningsreductiedwang geleid 
wordt in de richting van probleemoplossing in plaats van probleemvermijding. Leventhal maakt de reductie van spanning duidelijk aan de hand van angstaanjagende voorlichting. Het inboezemen van angst kan twee reacties oproepen, namelijk angstcontrole, gedrag waarmee vooral de emotionele reacties op het bericht onder controle worden gehouden, bijwoorbeeld ontkenning van het probleem en gevaarcontrole, gedrag waarmee vooral cognitief het gevaar onder controle wordt gehouden, bijvoorbeeld het oplossen van het probleem door het aanbevolen gedrag op te volgen. Tot deze groep theorieën rekenen we ook de eigen-effectiviteitstheorieën (zie hiervoor paragraaf 2.4 en paragraaf 3.6 ).

\section{Ego-defensieve theorieën}

Deze theorieën leggen de nadruk op de menselijke neiging om het zelfbeeld te handhaven in een persoonlijk te accepteren vorm. Middels selectieve waarneming, selectieve perceptie en selectieve retentie tracht de mens een positief zelfbeeld te verwerven. In dit kader zijn de opvattingen van Bem (1972) over zelfperceptie interessant. Hij gaat er vanuit dat de mens zijn eigen gedrag beoordeelt op uiterlijke kenmerken van anderen en van de omstandigheden waarin dat gedrag plaatsvindt. Anders geformuleerd, de persoon spiegelt zich aan gedragingen van anderen die hij zelf kan waarnemen. Op basis van deze observaties overweegt het individu hoe zijn eigen gedrag bij anderen dient over te komen. Volgens Bem is attitudeverandering dan ook het resultaat van het eigen gedrag in combinatie met externe informatie. Deze redenering van Bem komt erop neer dat, in tegenstelling tot de meeste andere theorieën, gedragsverandering aan attitudeverandering voorafgaat (zie ook paragraaf 5.7). Ook in het communicatiemodel van Maletzke wordt aan het zelfbeeld een belangrijke rol toebedeeld in die zin dat het zelfbeeld van de ontvanger bepalend is voor de mate van selectie van informatie. Door selectie vermindert de mens interne, psychische en fysische spanningen (Fauconnier, 1981). Het zelfbeeld wordt in sterke mate beinvloed door reacties en uitlatingen van anderen. Algemeen wordt aangenomen dat mensen de neiging hebben om zichzelf positief te waarderen en een positieve identiteit naar buiten willen brengen. De meeste mensen denken dat ze zelf eerlijker, vriendelijker en intelligenter zijn dan anderen. Ongelukken en problemen zullen ons zelf niet overkomen, maar anderen wel. De inschatting die mensen maken over hun eigen 
kwaliteiten en mogelijkheden, is vaak niet realistisch. De positieve zelfevaluatie leidt ertoe dat mensen in hun presentatie een positieve indruk willen maken. Koomen (1988) stelt dat uit positieve zelfevaluatie een ander verschijnsel voortvloeit, namelijk de zelfdienende vertekening ("self-serving bias") in attributie. Het behalen van succes schrijf je aan jezelf toe en falen aan anderen. Voor voorlichting heeft deze groep theorieën zowel positieve als negatieve implicaties. Bijvoorbeeld dient rekening gehouden te worden met de mogelijkheid van overschatting van de eigen competenties. Aan de andere kant biedt het feit dat mensen zich spiegelen aan positieve presentatie, vele mogelijkheden. McGuire vindt dat voorlichters vooral moeten benadrukken dat mensen in de gelegenheid zijn om op eigen kracht bepaalde problemen het hoofd te bieden of in staat zijn om een positief zelfbeeld te verwerven.

\section{Expressieve theorieën}

Deze theorieën hebben betrekking op de menselijke neiging om onderdrukte affecten af te reageren. Deze catharsis vinden we al terug in de opvattingen van Aristotoles: een tragedie stelt de toeschouwer in de gelegenheid om zijn gevoelens van angst, medelijden etc. de vrije loop te laten. Het moet gezegd dat deze theorieën te pas en te onpas gebruikt worden (Geen en Quanty, 1977). Zo wordt agressiviteit op de TV wel eens vergoelijkt door te stellen dat deze voor vele mensen in hun fantasie een uitlaatklep vormt waar ze anders echt in daden zou worden omgezet. Uit deze theorie kunnen we ook afleiden waarom mensen voldoening vinden in zware lichamelijke inspanning, in joggen en het opzettelijk risico nemen. Voor voorlichtingcampagnes impliceren deze theorieën o.a. dat een waarschuwende, belerende aanpak waarin op gevaren en risico's wordt ingegaan, vaak een omgekeerd effect sorteert (zie ook risico-homeostase onder de stimulatietheorieën). Het expliciteren van gevaren en risico's maakt het experimenteren extra attractief. Dit heeft bijvoorbeeld bij jongeren geleid tot een toename van drugs in plaats van tot een afname. 


\section{Herhalingstheorieën}

In deze groep van theorieën worden de ideeën van de behavioristen en de biologisch georiënteerde theoritici gebundeld. Zij benadrukken de tendensen die te vinden zijn in reeds uitgevoerde handelingen teneinde de persoon ertoe aan te zetten in het vervolg net zo te handelen. De idee achter deze theorieen is dat de uitvoering van handelingen in vergelijkbare situaties wordt beloond. Deze manier van denken vierde hoogtij in de jaren veertig, met name bij de contiguiteits-theoretici. Zij beweren dat herhaling van associaties al voldoet om de waarschijnlijkheid van toekomstige handelingen te vergroten. Dit gegeven staat in schril contrast met de versterking van het stimulus-respons-aspect, dat stelt dat handelingen zonder beloning een einde kunnen maken aan de response-neigingen. In publiekscampagnes wordt het herhalingsaspect met wisselend succes toegepast. Sawyer (1981) stelt dat herhaling na 3 tot 5 blootstellingen nog maar weinig additionele impact heeft. Hierbij moet worden aangetekend dat het eenzelfde boodschap betreft, die qua vormgeving en presentatie gelijk blijft. Zodra men echter dezelfde boodschap in de loop der tijd in wisselende modaliteit aanbiedt, neemt de kans op succes toe. Dit laatste gegeven ontlenen we aan de marketing-communicatie (Ferree, 1983; Roomer, 1987). Het is niet empirisch aangetoond, dus moeten we voorzichtig zijn met generalisatie. In de reclame-wereld zijn tientallen voorbeelden bekend waarin met continuering van eenzelfde concept gedurende tal van jaren grote successen zijn geboekt. Befaamd is het Coca-Colaconcept, en het bier van Heineken is al tientallen jaren heerlijk en helder. McGuire (1985) wijst erop dat bij gebruikmaking van het herhalingsaspect aandacht geschonken moet worden aan een toegevoegde waarde (bijvoorbeeld handelingsmogelijkheden aanbieden waarmee een belloning te verdienen valt of duidelijke identificatie) bij continuering van eenzelfde boodschap.

\section{De assertietheorieën}

Deze theorieën benadrukken het egoïstische, op macht georiënteerde aspect van de mens, het prestatiegericht zoeken naar succes en naar mogelijkheden om zijn eigen stempel op de wereld te drukken. Er zijn verschillende varianten op het thema macht. Adler vat die macht bijvoorbeeld op als de controle over anderen en Weiner (1974) benadrukt de geldingsbehoefte. Voorlichters kunnen dit aspect van men- 
selijke motivatie aangrijpen door aan te geven hoe het aanbevolen gedrag tegemoetkomt of bijdraagt aan het streven van de mens naar persoonlijke prestaties, status; etc. Het beheersen van de eigen situatie is de kern van de "learned helplessness"-theorie. Indien mensen bij voortduring geconfronteerd worden met het feit dat ze geen controle meer hebben over hun eigen situatie, neigen ze ertoe om in die situatie te berusten. Wanneer herhaaldelijk blijkt dat inspanningen niet helpen, vatten mensen dit op als hulpeloosheid. Bijvoorbeeld mensen die na een $x$-aantal vermageringspogingen het hoofd in de schoot werpen en het dikzijn als een onveranderbaar gegeven beschouwen. Hulpeloosheid en hopeloosheid gaan hier hand in hand. Het tegenovergestelde van "learned helplessness"-theorie is de "reactance"-theorie. Deze theorie beschrijft hoe mensen reageren op een bedreiging van hun vrijheid. Wanneer mensen in hun mogelijkheden beperkt worden, gaan ze zich verzetten om zo toch hun keuzemogelijkheden te continueren. We halen deze theorie aan omdat de "reactance"-theorie en de "learned helplessness"-theorie niet meer in hun oorspronkelijke vorm gehanteerd worden, maar geïntegreerd zijn tot éen theorie (Wortmann en Brehm, 1975). De geintegreerde theorie zegt dat een zeker gebrek aan grip op de eigen situatie leidt tot actief controleverhogend gedrag, terwijl een groot gebrek aan grip op de eigen situatie leidt tot passiviteit. In de voorlichting is het dus belangrijk om de eigen verantwoordelijkheid en het eigen initiatief van de betrokkene te benadrukken. Glijdt men af naar een toestand van hulpeloosheid, dan is voorlichting niet meer zinvol. Taylor (1986) heeft aangetoond dat interventies waarbij de nadruk ligt op het vermeerderen van controle, dus meer greep op de eigen situatie, bevredigende resultaten laten zien. Het moge duidelijk zijn dat de theorie van Wortmann en Brehm geplaatst moet worden in de schaduw van de assertie-theorieën. McGuire wijst er - wellicht ten overvloede - op dat het van belang is om het streven naar macht, controle en status op een positieve en creatieve manier in de doelstelling van een campagne op te nemen.

\section{Identificatie-theorieën}

Mensen verkrijgen genoegdoening wanneer ze hun eigen gedrag kunnen vereenzelvigen met het gedrag en de situatie van anderen. Identificatie-theorieën gaan er vanuit dat mensen zich ontplooien door bepaalde handelingen, gedachten en gevoelens over te nemen van 
anderen, die in herkenbare situaties verkeren en wier gedragingen tot voorbeeld strekken. Het identificatie-aspect vinden we in verschillende theorieen terug, bijvoorbeeld de rol- theorie van Newcomb, de referentiegroeptheorie van Hyman, de sociale vergelijkingstheorie van Sherif en de zelfpresentatietheorie van Goffman. Deze theorieën zijn goed toepasbaar in de voorlichting bij mensen die op zoek zijn naar hun eigen identiteit (bijvoorbeeld jongeren) en bij mensen die ten aanzien van een bepaald thema nog geen standpunt hebben ingenomen. De in een campagne opgenomen figuranten dienen dan afgeschilderd te worden als interessante en attractieve personages, die aan hun handelen veel genoegdoening beleven. In tv-spots worden vaak welbekende en geaccepteerde personen ten tonele gevoerd om hen te laten verhalen, dat het uit te voeren gedrag hen tot tevredenheid stemt.

\section{Empathie-theorieën}

De grondgedachte achter deze theoriee n is dat mensen de behoefte hebben om geaccepteerd en geliefd te zijn. In de meest primitieve vorm manifesteert zich dit in de drang om fysiek dicht bij anderen mensen te zijn. In voorlichtingscampagnes worden deze theorieën voornamelijk benut om de interpersoonlijke aantrekkingskracht te benadrukken. Berscheid en Walster (1978) hebben het belang van de behoefte om aantrekkelijk te zijn, beschreven aan de hand van voorlichtingscampagnes met betrekking tot gebitsverzorging en afslanken. Zij zijn de mening toegedaan dat aan de rol van lichamelijke attractiviteit meer aandacht besteed zou moeten worden dan aan de gevaren voor de gezondheid. Dit gegeven sluit nauw aan bij de opvattingen van Jonkers et al. (1988). Zij stellen dat gezondheidsoverwegingen, vaak het vertrekpunt voor GVO-interventies, van ondergeschikt belang zijn: "De maatschappelijke en persoonlijke voordelen van het ongewenste gedrag blijken in veel gevallen zwaarwegender dan de nadelen (gezondheidsrisico's)" (pag. 316). Zij pleiten er dan ook voor om de argumentatie in interventies meer toe te spitsen op de persoonlijke voordelen en het eigen belang voor de voorgelichte, met als mogelijk onderdeel de persoonlijke gezondheidswinst. Een ander aspect dat we uit de empathie-theorieën kunnen afleiden betreft de altruistische behoefte om anderen te helpen. McGuire geeft voorbeelden van voorlichtingscampagnes waarin gedragingen worden aanbevolen die nuttiger zijn voor mensen in het algemeen dan voor 
de doelpersoon in kwestie. Deze campagnes zijn met name succesrijk als geappelleerd wordt aan het persoonlijk verantwoordelijksgevoel van mensen bijvoorbeeld het ongeboren kind vrijwaren van de schadelijke invloed van rokende moeders. Mogelijkerwijze kunnen deze theorieên ingepast worden in een strategie om sociale dilemma's op te heffen (zie ook paragraaf 1.5).

\section{De imitatietheorieën}

Onder de paraplu van imitatietheorieèn is een grote verscheidenheid aan theorieën, zoals modelling, sociale facilitatie, imitatie en de sociale leertheorie onder te brengen. Het gemeenschappelijke van deze theorieën is de neiging van mensen tot imitatie van anderen, waarbij ze als het ware automatisch gedachten overnemen, gevoelens delen en gedragingen nadoen.

In de praktijk blijkt de toepassing van deze theorieën zeer bruikbaar: leren-door-navolging kan gebruikt worden in vele situaties, er kunnen geheel nieuwe gedragspatronen geleerd worden, het aangeleerde gedrag kan zich over langere periodes handhaven en bestaande, ongewenste gedragspatronen kunnen afgeleerd worden $\left(\mathrm{Kok}_{*}\right.$ Wilke en Meertens, 1987).

Het aanwenden van de inzichten uit de imitatietheorieën is voor voorlichtingsactiviteiten zeer zinvol, als men voldoende aandacht schenkt aan bekrachtiging van imitatie. De voorgelichten dienen bij voortduring te ervaren dat uitvoering van het gewenste gedrag gepaard gaat met positieve terugkoppeling, instemming, bijval en enthousiasme. Beekers (1982) wijst op een aantal factoren die van belang zijn om het bekrachtigingsmechanisme effectiever aan te wenden: moment van en gelegenheid tot bekrachtiging, dosering van bekrachtiging, type bekrachtiging, onderbreking van bekrachtiging en "response-contingente"-bekrachtiging (kwantiteit en kwaliteit van de bekrachtiging dienen evenredig te zijn aan de "prestatie" van de voorgelichte). Bandura $(1972,1976)$ heeft zich met de sociale leertheorie, die later is uitgewerkt tot het zogenaamd "reciproque determinisme" (1986) (gedrag, cognitieve en andere persoonsgebonden factoren alsmede de externe omgeving beïnvloeden elkaar wederkerig) op dit terrein bijzonder verdienstelijk gemaakt. Met name de persoonlijke effectiviteitsbenadering oogst binnen de gezondheidsvoorlichting veel waardering (Seydel, 1989; Strecher, 1983; Taylor et al., 1985). De persoonlijke effectiviteisbenadering richt zich op de subjectieve percep- 
the van individuen om zelf invloed op het gedrag te kunnen uitoefenen. Het uitgangspunt is dat de keuze voor een bepaald gedrag(salternatief) wordt bepaald door de inschatting van de kans dat bepaald gedrag effecten sorteert die gekoppeld zijn aan een bepaalde waardering. Specifiek gedrag onder specifieke condities is een functie van de uitkomstverwachtingen (de perceptie ten aanzien van de resultaten van het opvolgen van bepaalde aanbevelingen) en de persoonlijke effectiviteitsverwachtingen (de inschatting van de eigen competentie om het betreffende gedrag tot ontwikkeling te brengen, uit te voeren en te handhaven). Bandura (1986) noemt een viertal informatiebronnen die voorlichters kunnen benutten om de persoonlijke-effectiviteitsverwachtingen van de doelpopulatie te beinvloeden:

1. leren door observatie van een model ("vicarious experience");

2. ervaringen opdoen in opklimmende moeilijkheidsgraad ("performance accomplishments");

3. verbale beïnvloeding; het verstrekken van feitelijke informatie, instructies, aanmoedigingen, suggesties etc.;

4. het interpreteren van autonome arousal en spanning; dat wil zeggen de interpretatie van de fysiologische gesteldheid van het eigen lichaam.

Resumerend kunnen we de poging van McGuire om de diverse inzichten uit de sociale psychologie te integreren in een raamwerk van zestien theorieën als waardevol aanmerken. We dienen daarbij niet uit het oog te verliezen dat McGuire erop gewezen heeft dat het niet mogelijk is om het succes of falen van interventies in én theorie te bundelen. Daarvoor is de materie veel te complex. De theoretische fundering kan goed gebruikt worden als een itinerarium bij de planning van interventies. Aan deze fundering kleeft ook een aantal zwakke punten. De opsomming van de theorieën wordt gekenmerkt door een zekere mate van vrijblijvendheid in de zin dat te veel gelegenheid wordt geboden voor vrije interpretatie van de theorieën. Dit bemoeilijkt de reflectie naar praktische consequenties voor de voorlichting. Bij sommige theorieèn is het niet eenvoudig om grondige verschillen vast te stellen. Zo zijn bijvoorbeeld de consequenties voor de voorlichting van de identificatie- en empathie-theorieën nagenoeg identiek. Sommige theorieenn overlappen elkaar zodat men betrekkelijk willekeurig bepaalde thema's/inzichten in een categorie kan onderbrengen. Deze kritische noten staan slechts in de schaduw van de positieve bijdrage die deze theoretische inzichten hebben voor de 
planning van interventies. Het is opmerkelijk, 20 niet merkwaardig, dat er zowel in de literatuur als in de praktijk weinig gerefereerd wordt aan de achtergronden van de communicatiematrix.

Flay et al. (1981) heeft middels evaluatie-onderzoek onderzocht in hoeverre de afhankelijke variabelen in het stochastische proces van toepassing zijn op massamediale (gezondheids-) voorlichtingscampagnes. Zij kwamen tot de trieste conclusie dat slechts enkele campagnes tot gedragsverandering hadden geleid (Best, 1980; McAlister, 1976; Mendelsohn, 1973; North Karelia en Stanford Three Community Projects; Warner, 1977). Een verklaring voor het falen van de campagnes moet volgens Flay gezocht worden in het niet systematisch toepassen van elementaire communicatieprincipes bij het voorbereiden, ontwerpen en evalueren van campagnes en een aantal zwakke punten in het informatieprocesmodel. Ten aanzien van dit laatste moeten we constateren dat het tijdsperspectief in het model van McGuire nagenoeg ontbreekt. Er is bijvoorbeeld geen onderscheid aangebracht tussen doelen op korte, middellange en lange termijn. Zo stellen Hass en Mann (1976) dat onmiddellijke reacties niet als belangrijke veranderingen kunnen worden aangemerkt. Ook Rogers (1983) stelt dat eenmaal veranderd gedrag geen garantie biedt voor gedragsbehoud. Een studie van de condities onder welke attitudeverandering op termijn voortduurt, kwam van de hand van Cook en Flay (1978). Zij stellen dat een voorlichtingsboodschap in massamediale campagnes de meeste impact heeft als ze:

a. afkomstig is van meer zeer geloofwaardige bronnen, die met elkaar vergelijkbaar zijn qua attractiviteit, deskundigheid en betrouwbaarheid;

b. vaak, consequent en langdurig wordt herhaald;

c. wordt gestuurd via verschillende media op toegankelijke tijden en plaatsen;

d. grote persoonlijke betrokkenheid oproept en overeenkomt met attituden- en waardenstructuren die er betrekking op hebben.

McGuire heeft in zijn tijd nog drie andere belangrijke factoren over het hoofd gezien, namelijk (1.) de rol van sociale ondersteunig en de invloed van de directe sociale omgeving van de ontvanger; (2.) de mogelijkheid om nieuw gevormde attitudes te toetsen of uit te proberen; (3.) bekrachtiging van de gewenste handelingen. In het navolgende zullen we enkele courante modellen behandelen, die voortbou- 
wen op het informatieprocesmodel en die (deels) de kritiek op McGuire kunnen doorstaan.

\subsection{Het model van gedragsverandering door voorlichting}

Het model van Kok (1985) is te beschouwen als een fasenmodel, waarin stapsgewijs wordt aangegeven welke fasen doorlopen moeten worden om uiteindelijk gedragsbehoud te bereiken. Kok heeft de modellen van McGuire (1973, 1974, 1985), Rogers (1983) en Fishbein en Ajzen (1975, 1980) geïntegreerd en tegelijkertijd per fase aangegeven welke variabelen van belang zijn om het proces te continueren.

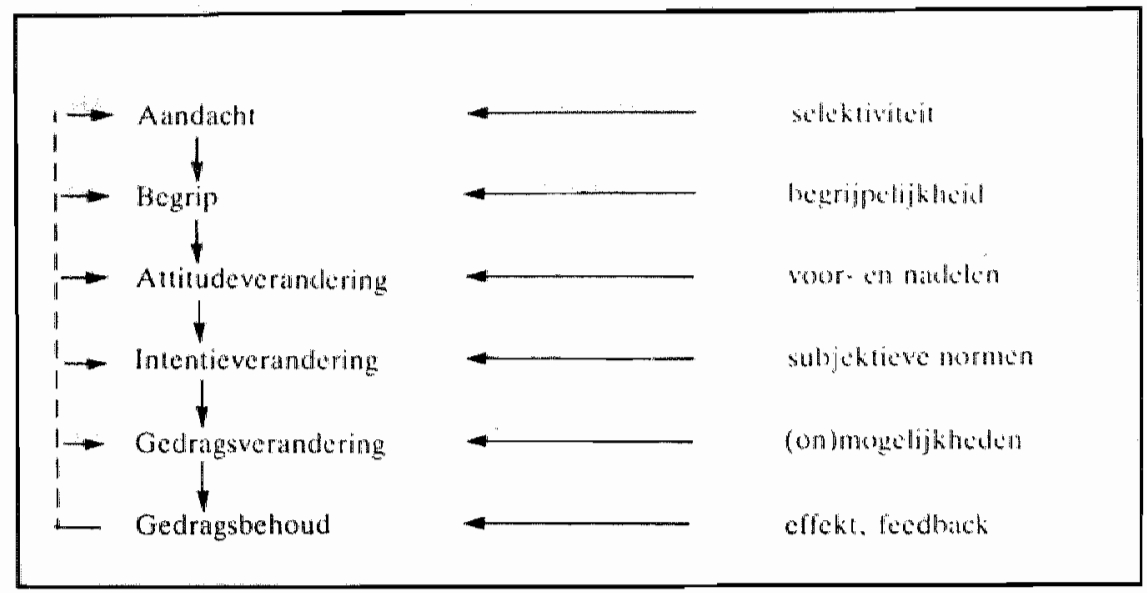

Figuur 5.4 Model van gedragsverandering via voorlichting.

Bron: Kok, 1985, pag. 72.

De eerste twee fasen, afkomstig van McGuire, geven aan dat attitudeverandering pas kan plaatsvinden, wanneer de ontvanger blootgesteld is aan de informatie, er aandacht aan schenkt en de inhoud ervan begrijpt. In de aandachtfase moet de voorlichter vooral rekening houden met een aantal selectiviteitsvariabelen: selectieve blootstelling, selectieve perceptie en selectieve interpretatie. Deze selectiemechanismen verklaren waarom bepaalde boodschappen wel of niet 
doordringen tot het publiek en geven inzicht in de manier waarop mensen de boodschap verwerken. De verschillen tussen de sellectiemechanismen zijn doorgaans niet scherp; soms vloeien ze in elkaar over, soms overlappen ze elkaar. Ten aanzien van de selectieve blootstelling dient opgemerkt te worden dat selectie van informatie bewust en onbewust kan plaatsvinden. Bij voorkeur stellen mensen zich bloot aan informatie, die ze graag willen horen en vermijden ze informatie die een bedreiging voor ze vormt of hen niet goed van pas komt. Er kunnen allerlei factoren in het spel zijn die bepalen of iemand bereid is te luisteren of te kijken. Indien de ontvanger bij een vluchtige blik het idee krijgt dat de informatie functioneel is, zal de kans dat hij er kennis van neemt, toenemen. Ook technische oorzaken kunnen er debet aan zijn dat de informatie niet of nauwelijks wordt opgemerkt bijvoorbeeld wanneer de informatie onzuiver (niet leesbaar) of moeilijk toegankelijk is (complex taalgebruik of te kleine letterties).

De informatie bereikt de doelgroep ook niet op het moment dat deze er niet ontvankelijk voor is. Bij selectieve perceptie gaat het om de mate waarin de informatie persoonlijk ingekleurd wordt. Nauw verwant met het begrip perceptie is de term interpretatie: de wijze waarop eenzelfde fysische-sociale informatie-eenheid op verschillende manieren kan worden uitgelegd. Het verschil tussen perceptie en interpretatie is hierin gelegen dat interpretatie afhankelijk is van factoren in de persoon zelf en zich op inhoudsniveau afspeelt, terwijl perceptie betrekking heeft op factoren in de situatie zoals die door de persoon wordt gezien.

Eagly en Chaiken (1984) hebben er herhaaldelijk op gewezen dat de voorlichter zich rekenschap moet geven van de selectiemechanismen en dringen erop aan deze mechanismen expliciet aan de orde te stellen in een pretest.

De fasen van attitudeverandering middels intentieverandering naar gedragsverandering ontleent Kok aan de theorie van Fishbein en Ajzen (1975) en Ajzen en Fishbein (1980). Het model gaat uit van beredeneerd gedrag; dat wil zeggen dat een persoon een afweging maakt van voor- en nadelen die aan een bepaalde manier van gedragen verbonden zijn. Deze afweging van persoonlijke voor- en nadelen komt tot uiting in de attitude van de persoon. Daarnaast laat een persoon zich leiden door de invloed vanuit de sociale omgeving, de zogenaamd subjectieve norm. De subjectieve norm bestaat uit twee 
elementen namelijk (a.) de referent-opvatting (normatieve beliefs): de waargenomen opvattingen van anderen en (b.) de geneigdheid om te conformeren (motivation to comply): de mate waarin een persoon instemt met de mening van belangrijke anderen. Volgens Fishbein en Ajzen blijkt het gedrag van een persoon het best te worden voorspeld vanuit de intentie tot dat gedrag. De intentie wordt bepaald door de attitude en de subjectieve norm. De relatie tussen intentie en gedrag kan door verschillende factoren verstoord worden. Er kunnen namelijk allerlei externe barrières zijn waardoor de voornemens niet tot uitvoering gebracht kunnen worden. Echter het feit dat de persoon zelf in staat moet zijn om de gewenste reactie in daden om te zetten, legt het grootste gewicht in de schaal. (Bandura, 1977; Leventhal, 1970; Rogers, 1983).

Gedragsverandering heeft de meeste kans van slagen als aan het nieuwe gedrag voldoende gratificaties verbonden zijn. Naast het meest belonende gedragsalternatief moeten mensen er ook van overtuigd zijn dat ze het gewenste gedrag kunnen realiseren. De inschatting van de eigen competentie om bepaald gedrag uit te voeren wordt door Strecher (1986) persoonlijke effectiviteit genoemd ("selfefficacy"). De ervaren self-efficacy bepaalt de keuze van activiteiten, de mate van inspanning, de mate van volhouden en zo het uiteindelijk gedrag.

Al eerder had Bandura (1977) gewezen op het feit dat de individueel gebonden inschatting om op eigen kracht gedragsdoelen te bereiken een belangrijke variabele was in het verklaren van gedrag. Naast persoonlijke effectiviteit hanteert Bandura de term "outcome expectations". Deze heeft betrekking op de voordelen, die verbonden zijn aan het vertonen van bepaald gedrag. We vertalen deze term met gedragseffectiviteit. Schematisch wordt de werking van deze variabelen in figuur 5.5 weergegeven.

De fase van gedragsverandering naar gedragsbehoud in het model van Kok is gebaseerd op het fasenmodel van E.M. Rogers (1983). Eenmaal veranderd gedrag moet ook beklijven in de zin dat er permanente verandering bereikt wordt. Rogers wijst erop dat het vooral de ervaringen met het nieuwe gedrag zijn die bepalend zijn ten aanzien van gedragsbehoud. Teneinde gedragsbehoud te realiseren dient de voorgelichte optimale feedback te ontvangen over het effect van het gedrag. Siero et al. (1985) hebben aangetoond dat frequente feedback over positieve resultaten van de gedragsverande- 
ring een gunstige uitwerking heeft op het behouden van gedrag. Feedback kan opgevat worden als een vorm van sociale ondersteuning. Met name sociale ondersteuning vanuit de directe sociale omgeving (bijvoorbeeld de partner) is van belang voor gedragsbehoud (Abrahams en Follick, 1983).

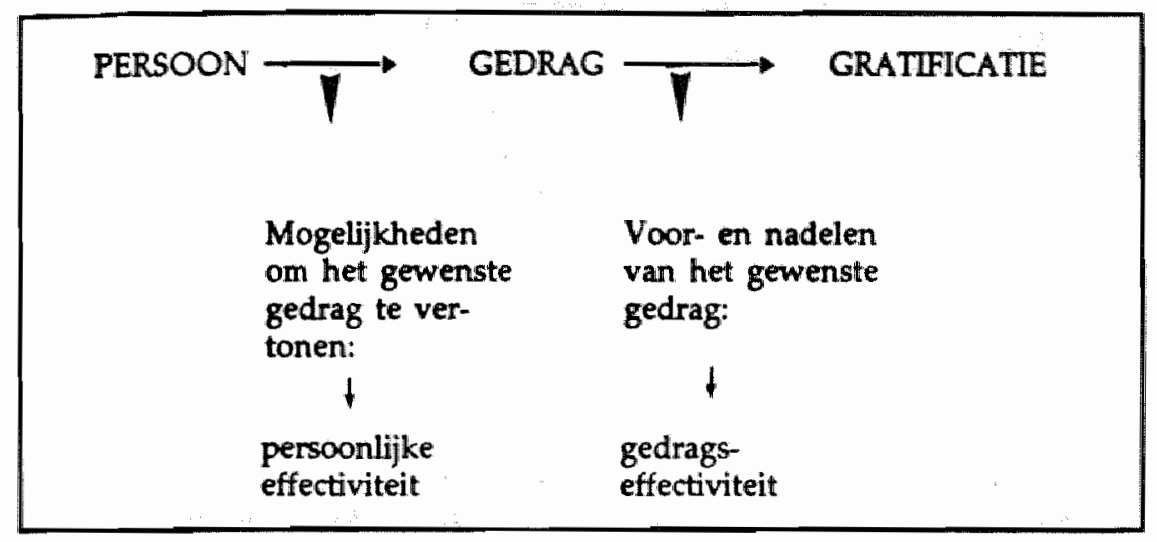

Figutur 5.5 Persoonlijke en Gedragseffectiviteit.

Bron: Kok, 1987, pag. 80.

Voor het behoud van gedrag is ook de attributietheorie van Weiner (1986) van belang. Globaal genomen stelt de attributietheorie dat menselijk gedrag gemotiveerd wordt door de interpretatie die mensen geven aan de oorzaak van een gebeurtenis. Attributies zijn gepercipieerde oorzaken, bijvoorbeeld persoonlijke aanleg, de mate van inspanning en taakmoeilijkheid. Naast attributies zijn emoties en succesverwachting de belangrijkste variabelen in de attributietheorie. De succesverwachting wordt bepaald door de mate van stabiliteit van een waargenomen oorzaak van vorig succes of falen met betrekking tot hetzelfde soort gedrag. De mate van controleerbaarheid en de plaats (intern of extern) van de oorzaak zijn bepalend voor het optreden van emoties. Deze emoties bepalen samen met de succesverwachting het toekomstig gedrag. Eiser et al. (1986) hebben de attributietheorie toegepast in een voorlichtingsprogramma en concluderen dat de voorlichter ervoor moet waken dat het publiek de 
kansen op het uitvoeren van gewenst gedrag realistisch moet inschatten. Het publiek dient voorbereid te worden op problemen, die opdoemen bij het continueren van het nieuwe gedrag. Ook stelt Eiser dat het opvolgen van de voorlichtingsboodschap als effectief ervaren moet worden, zodat mogelijk falen niet geattribueerd wordt aan stabiele factoren. Dit laatste is ook de kern van Roger's model, namelijk dat het nieuwe gedrag inderdaad leidt tot het gewenste effect.

Wellicht ten overvloede zij erop gewezen dat Kok's model niet als een specifiek massamediaal model kan worden aangemerkt. De meerwaarde van dit model schuilt voornamelijk in de aandacht voor de overgang van attitude naar gedragsverandering en de belangrijke rol van sociale ondersteuning voor bekrachtiging van gedrag.

\subsection{Het Elaboration-Likelihoodmodel}

Het Elaboration-Likelihoodmodel (E.L.M.) van Petty en Cacioppo (1986) is het resultaat van een bundeling van researchgegevens die de afgelopen decennia zijn verzameld op het gebied van attitudeverandering. Het is, evenals het informatieprocesmodel, een cognitief georiënteerd model, dat in grote lijnen overeenkomt met de afhankelijke variabelen (de zogenaamde twaalf stappen) van McGuire. Het model is gestoeld op de volgende assumpties (Petty en Cacioppo, 1986, pag. 5):

1. Mensen zijn gemotiveerd om juiste attitudes er op na te houden.

2. Hoewel mensen er correcte attitudes op na willen houden, bestaan er door individuele en situationele factoren, variaties in de omvang en aard van de verwerking van het onderwerp waarmee ze zich bezig willen en kunnen houden en waardoor (uiteindelijk) een boodschap wordt geevalueerd.

3. Variabelen kunnen de omvang en richting beïnvloeden van attitudeverandering, doordat ze (a) dienen als overtuigingsfactoren, (b) dienen als secundaire prikkels, en/of (c) invloed hebben op de omvang of richting van de verwerking van onderwerp en argumenten.

4. Variabelen die invloed hebben op de motivatie en/of het vermogen om een boodschap te verwerken op een betrekkelijk objectieve manier, doen dat doordat ze kritische beoordeling van argumenten bevorderen ofwel verminderen. 
5. Variabelen die op een bevooroordelende manier invloed hebben op het verwerken van een boodschap, kunnen bias veroorzaken in de gedachten over het onderwerp, die zowel positief kan zijn als negatief ten aanzien van de motivatie en/of het vermogen tot verwerken.

6. Bij vermindering van de motivatie en/of het vermogen om argumenten te verwerken, worden perifere prikkels relatief belangrijker dan determinanten van persuasion. En omgekeerd, als nauwkeurig onderzoek van de argumenten groter wordt, dan worden de perifere prikkels relatief minder belangrijk dan determinanten van persuasion.

7. Attitudeveranderingen die het gevolg zijn van het verwerken van argumenten betreffende het onderwerp (centrale route), zullen langer beklijven, betere voorspellers van gedrag zijn en grotere weerstand bieden tegen overreding dan attitudeveranderingen die hoofdzakelijk het gevolg zijn van perifere prikkels (perifere route).

Het model postuleert enerzijds attitudeverandering via de centrale route en anderzijds attitudeverandering via de perifere route. Attitudeverandering via de centrale route komt tot stand, wanneer de ontvanger een persuasieve boodschap zorgvuldig beoordeelt op de argumenten die in de boodschap gehanteerd worden. Bij het volgen van de perifere route vindt attitudeverandering niet plaats op basis van afweging van argumenten, maar is attitudeverandering gebaseerd op een of meer (oppervlakkige) kenmerken van de boodschap of van de context waarin de communicatie plaatsvindt (bijvoorbeeld de geloofwaardigheid van de bron of de attractiviteit van het voorlichtingsmateriaal). Welke route gevolgd gaat worden, is afhankelijk van de mate waarin de ontvanger een zorgvuldige afweging kan maken van sterke en zwakke argumenten. Dit proces wordt gestuurd door het persoonlijke belang dat de ontvanger aan de boodschap hecht en de behoefte aan cognitieve structurering. Naarmate het persoonlijk belang voor de ontvanger toeneemt, is hij meer geneigd om een kritische afweging te maken. Ergo geldt dit voor de behoefte aan structurering. Deze twee factoren zijn bepalend voor de motivatie van een individu om informatie cognitief te verwerken. Naast deze motivatie moet hij in staat zijn tot deze verwerking, met andere woorden hij dient te beschikken over bekwaamheden (vaardigheden). Deze bekwaamheden worden gedetermineerd door sociale invloeden (bijvoorbeeld storende invloeden tijdens de presentatie van de bood- 
schap) of door individuele factoren (bijvoorbeeld intelligentie). Voor het verwerken van informatie is het zaak dat de ontvanger de gelegenheid krijgt om na te denken en dat hij bij herhaling voorzien wordt van informatie. De wijze waarop de informatie cognitief verwerkt wordt, is (onder meer) afhankelijk van de aanvankelijke attitude( $n$ ) en de kwaliteit van de argumenten. Lage involvering en lage cognitieve structurering zal leiden tot geen of een neutrale cognitieve respons zodat waarschijnlijk attitudeverandering via de perifere route zal plaatsvinden. Een positieve dan wel negatieve respons zal leiden tot verandering in cognitieve structuur via de centrale route. Indien de nieuwe cognities worden aanvaard, in het geheugen worden opgeslagen en voldoende saillant zijn, zal centrale attitudeverandering optreden. In Figuur 5.6 wordt het proces overzichtelijk weergegeven.

Attitudeverandering die via de centrale route tot stand komt, zal volgens het model in het algemeen relatief stabiel zijn en moeilijk te beinvloeden. Op de lange termijn zal het gedrag echter beter te voorspellen zijn dan gedragsverandering die via de perifere route verloopt.

Zoals gezegd kan het Elaboration-Likelihoodmodel als een sjabloon over de twaalf stappen van McGuire heengelegd worden. De derde stap in het model van McQuire is sterk gerelateerd aan de motivationele factoren in het Elaboration-Likelihoodmodel; de vierde stap valt samen met de bekwaamheden ("ability key"). Zowel de centrale als de perifere route van Petty en Cacioppo bestrijken de eerste 7 stappen van McGuire. Vanaf stap 8 (het opslaan van de informatie in het geheugen) tot en met gedragsbehoud (stap 12) zullen veranderingen plaatsvinden onder hoge elaboration likelihood condities, dat wil zeggen de centrale route van overtuiging zal gevolgd worden. Bij lage elaboration condities cq. de perifere route zal het model niet verder reiken dan de eerste zeven stappen van McGuire. Het ElaborationLikelihoodmodel van Petty en Cacioppo boet nog meer aan orginaliteit in, als we bedenken dat de twee routes veel gelijkenis vertonen met het systematisch versus heuristisch informatieprocesmodel van Chaiken (1980). Het systematisch procesmodel (overreding vindt plaats op basis van persoonlijk relevant geachte informatie) correspondeert met de centrale route; het heuristisch model (overreding vindt plaats op grond van stimuli uit de communicatiecontext door middel van eenvoudige beslissingsregels) correspondeert met de perifere route. 


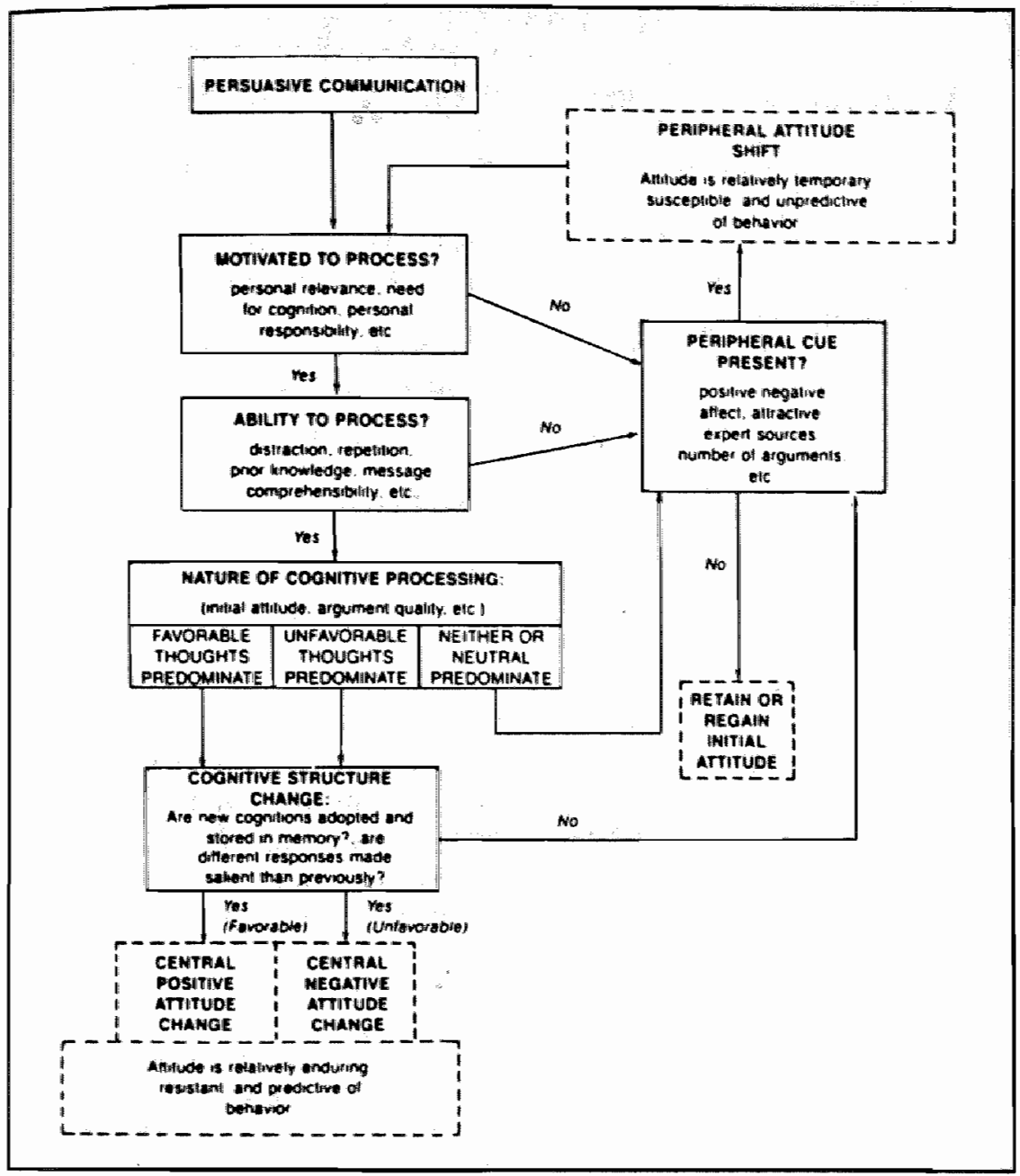

Figur 5.6 Het Elaboration-Likelihoodmodel of persuasion. Bron: Petty en Cacioppo, 1986, pag. 4.

Ofschoon in de literatuur concensus bestaat over de bruikbaarheid van basisprincipes van het model, kan het model de toets der kritiek niet geheel doorstaan. Zo noemt Verplanken (1989) als negatief punt 
het feit dat niet is aangegeven wanneer een argument zwak danwel sterk is. Dit impliceert dat het niet duidelijk is hoe een voorlichtingsboodschap via de centrale route dan wel via de perifere route samengesteld moet worden. Ook is volgens Verplanken onduidelijk wat de werking van de "perifere cues" is en onder welke omstandigheden zij optreden. Voorts is het zeer twijfelachtig of het model geschikt is voor toepassing in de praktijk, omdat de onderzoeken niet in natuurlijke situaties hebben plaatsgevonden maar veelal in laboratoriumexperimenten met studenten als onderzoekspopulatie.

Verplanken heeft het model wel toegepast in een natuurlijke context als veldexperiment waarin effecten van een overredende communicatie over risico's van het grootschalig gebruik van kolen voor het opwekken van electriciteit werden onderzocht. Hij concludeert op basis van dit veldexperiment dat het Elaboration-Likelihoodmodel grotendeels wordt bevestigd maar dat nader onderzoek naar persistentie-effecten en de werking van "perifere cues" noodzakelijk is.

\subsection{Het integratiemodel}

Flay (1981) heeft een grondige studie gemaakt van geëvalueerde massamediale programma's en komt tot de conclusie dat het informatieprocesmodel een duidelijk paradigma biedt voor de planning en beoordeling van massamediale campagnes maar dat het model tekort schiet bij toepassing in de praktijk Als belangrijkste bezwaren noemt Flay: de rol van sociale ondersteuning en de invloed van de directe sociale omgeving komen onvoldoende tot zijn recht, de matrix van McGuire i.c. het informatieprocesmodel biedt onvoldoende mogelijkheden om nieuw gevormde attitudes te toetsen of uit te proberen. Flay betreurt het tenslotte dat er nauwelijks aandacht geschonken wordt aan feedback in de vorm van bekrachtiging van de gewenste handelingen. We zullen de belangrijkste bevindingen van Flay weergeven en een beschrijving geven van het model dat hij op basis van zijn studie heeft gecomponeerd.

Flay stelt dat de meeste programma's in het algemeen het effectiefst zijn in het veranderen van kennis. Veranderingen in attitude werden aanzienlijk minder vaak waargenomen en gedragsveranderingen slechts zelden. De belangrijkste en meest geformuleerde doelstelling 
van gezondheidsvoorlichtingsprogramma's, namelijk het verbeteren van de gezondheidstoestand, wordt niet bereikt.

Veel massamediale gezondheidsprogramma's mislukken omdat men er te gemakkelijk vanuit gaat dat men met inzet van de media het publiek well bereikt. De doelgroep wordt ofwel niet op de juiste plaats ofwel riet op het juiste tijdstip blootgesteld aan de voorlichtingsboodschap. Voorts slagen voorlichters er vaak niet in mensen te motiveren om aandacht te besteden aan de boodschap. Men houdt onvoldoende rekening met selectieve blootstelling. Flay constateert dat degenen die al gemotiveerd zijn en over voldoende kennis beschikken de meeste belangstelling tonen voor de voorlichtingsprogramma's. Volgens Flay is voor het vergroten van kennis ieder medium geschikt; echter voor het veranderen van beliefs en attitudes is het zaak om een zorgvuldige afweging te maken ten aanzien van het functionele gebruik van de verschillende media en/of het inzetten van een combinatie van media. Evaluaties van massamediale programma's die significante veranderingen in beliefs en of attitudes registreerden, suggereren dat de factoren die de meeste invloed op zulke veranderingen hebben de volgende zijn:

a. opwekking van de betrokkenheid met het onderwerp en/of van de motivatie om te veranderen;

b. veel herhalingen door verschillende bronnen, via vele media over lange perioden (dat wil zeggen maanden of jaren, niet dagen of weken);

c. orginaliteit en creativiteit in de manier waarop de boodschap wordt gepresenteerd (om aandacht vast te houden en de betrokkenheid op te wekken);

d. gerichtheid op zeer specifieke onderwerpen en voorzien in alternatieve attitudestructuren;

e. hoge kwaliteit van materialen, gelijkwaardig aan die in de commercièle massamedia.

Massamediale campagnes die op gedragsniveau effectief bleken te zijn, kenmerken zich door aandacht te schenken aan:

1. het ontwikkelen van vaardigheden benodigd om het gewenste gedrag uit te voeren;

2. informatie verschaffen over verschillende gedragsalternatieven;

3. stimulering van interactie met het publiek (bijvoorbeeld via telefoon of schriftelijk materiaal); 
4. aanvulling met en ondersteuning van interpersonale communicatie (bijvoorbeeld cursussen);

5. mobilisatie of herstructurering van gemeenschappelijke middelen (bijvoorbeeld samenwerken met een industrie om bepaalde producten te ontwikkelen).

Het belangrijkste probleem waarmee Flay worstelt, is het feit dat cognitieve veranderingen automatisch zullen leiden tot gedragsveranderingen. Hij stelt dat informatie, hoe overtuigend deze ook is, zelden beduidende of langdurige gedragsveranderingen veroorzaakt. De fasen van de beschreven modellen zijn te beschouwen als voorwaarden voor het optreden van veranderingen, maar bieden op zichzelf geen garantie dat het proces daarmee gecontinueerd wordt en uiteindelijk zal resulteren in gedragsbehoud. Niet voor niets duidt McGuire zijn attitudeveranderings als stochastisch aan!

Op zoek naar reconceptualisatie van het informatieverwerkingsmodel, brengt Flay onderscheid aan tussen veranderingen in kennis en/of beliefs en veranderingen van attitude, intentie en gedrag. Kennis kan gedefinieerd worden als feitelijke informatie, die empirisch gemeten kan worden als een vaststaand of universeel gegeven. Beliefs (opvattingen) hebben betrekking op de mate waarop iemand subjectief aanvaardt dat er een verband bestaat tussen een bepaald voorwerp of gedrag en een attitude of consequentie. Een belief is in de ogen van Flay een persoonlijke schatting van subjectieve waarschijnlijkheid waarmee verschillende graden van zekerheid worden uitgedrukt. Veranderingen in kennis kunnen leiden tot veranderingen in beliefs. Dit is wat McGuire "acceptance" of "yielding" noemt, namelijk veranderingen in beliefs gebaseerd op nieuwe kennis. Een attitude is conform Fishbein en Ajzen (1975) een evaluatieve (affectieve) reactie op een handeling of actie. Flay heeft bedenkingen of een attitude nog wel tot de cognitieve structuur gerekend kan worden. Hij vermoedt dat McGuire's indeling terug te voeren is op de ideeën van Cartwright (1949), die kennis en beliefs classificeerde als cognitieve structuur, attitudes en waarden als motivatiestructuur en intenties, gedrag en de invloed uit de omgeving als gedragsstructuur. We delen Flay's mening dat het Model van McGuire opgevat dient te worden als een veranderingsmodel voor de cognitieve structuur. Ook Kok (1985) is kennelijk deze mening toegedaan, want in zijn model zijn de eerste fasen ingeruimd voor de inzichten van McGuire. Schematisch 
kan de reconceptualisatie van het informatieproces als volgt worden weergegeven:

$\begin{array}{ccc}\text { Independent Variables } & \text { Intermediate (antecedent) } & \text { Dependent Variables } \\ \text { (Communication Factors) } & \text { Processes } & \text { (Outcome) }\end{array}$

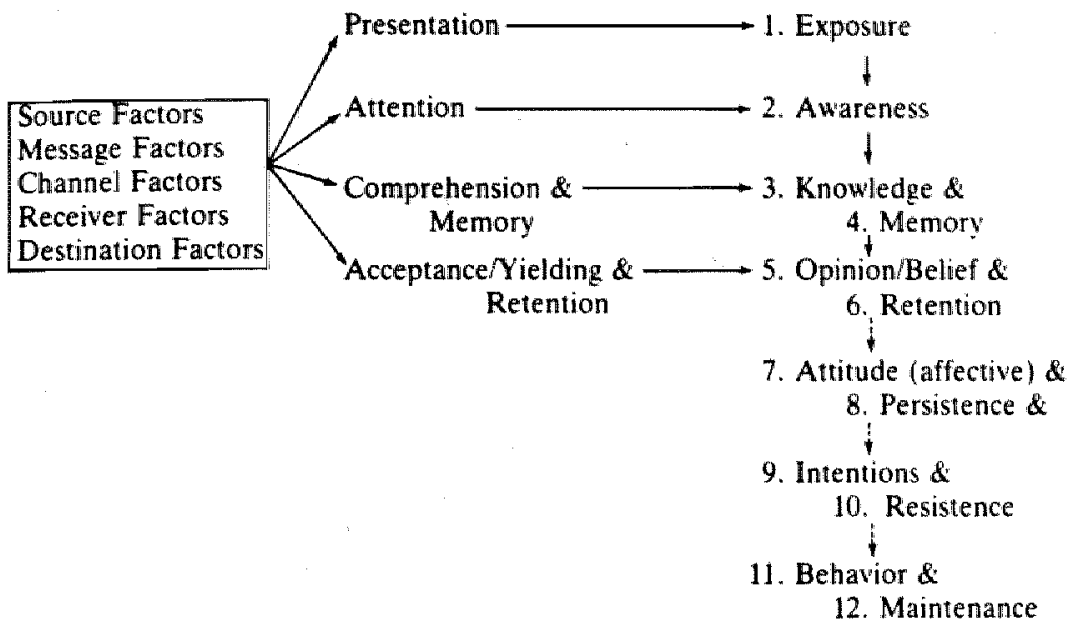

Figuur 5.7 Reconceptualisatie van het informatieprocesmodel.

Bron: Flay et al., 1980, pag. 68.

De pijlen van de ene afhankelijke variabele naar de andere suggereren een causaal verband, daar waar:

* blootstelling zal leiden tot bewustwording, maar alleen wanneer aandacht aan de boodschap wordt besteed;

* bewustwording zall leiden tot veranderingen in kennis, maar alleen wanneer de boodschap wordt begrepen;

* veranderingen in kennis zullen leiden tot veranderingen in beliefs, maar alleen als de argumenten of conclusies van de boodschap worden geaccepteerd of als eraan toegegeven wordt; 
* veranderingen in beliefs zouden kunnen (let op de onderbroken pijlen) leiden tot veranderingen in attitudes, intenties en gedrag.

Een mogelijke verklaring waarom men aanneemt dat veranderingen in de cognitieve structuur overgaan in attitudeverandering, komt voornamelijk vanuit de hoek van de consistentietheorieën. Men dient daarbij te bedenken dat andere factoren dan alleen overtuigende boodschappen daar verantwoordelijk voor zijn. We denken hierbij aan omgevingsvariabelen, vaardigheden, sociale ondersteuning, feedback, effectiviteitsverwachtingen, bevestiging/bekrachtiging van gedrag door interpersonale communicatie, etc..

Flay tracht op basis van, betrekkelijk recente, sociaal-psychologische inzichten vorm te geven aan een model dat toepasbaar is voor de massacommunicatieve praktijk. Als uitgangspunt hanteert hij de variabelen uit het informatieprocesmodel, omdat dit de beste omschrijving geeft van de condities waaronder veranderingen in kennis en beliefs kunnen worden bewerkstelligd. De affectieve- en gedragsstructuur wordt aangevuld met recente inzichten, toepassingen en empirische verworvenheden uit de theorie van het beredeneerde gedrag (Fishbein en Ajzen, 1975), het Health Belief Model (Becker, 1974), de sociale leertheorie (Bandura, 1977), het protectie-motivatiemodel van Rogers (1975) en de attributietheorie Jones en Davis, 1965; Kelley, 1967). Het model wordt schematisch weergegeven in figuur 5.8.

Naast een beschrijving van de belangrijkste condities die veranderingen teweegbrengen in de cognitieve structuur, geeft dit model een beschrijving van attitude- en gedragsverandering door massamediale campagnes. Het model stelt dat:

a. attitudes worden voorspeld zowel door waarden en verwachtingen als door beliefs;

b. intenties worden voorspeld zowel door sociale normatieve beliefs en persoonlijkheidsvariabelen als door attitudes;

c. uitprobeergedrag alleen voorspeld zal worden door intenties indien geschikte (betrouwbare) bronnen aanwezig zijn, alternatieve (gedrags)-vaardigheden zijn aangeleerd en/of iemand zichzelf in staat acht/competent is om het gedrag uit te voeren;

d. gedrag alleen herhaald en gehandhaafd zal worden als het voldoende wordt bekrachtigd. 


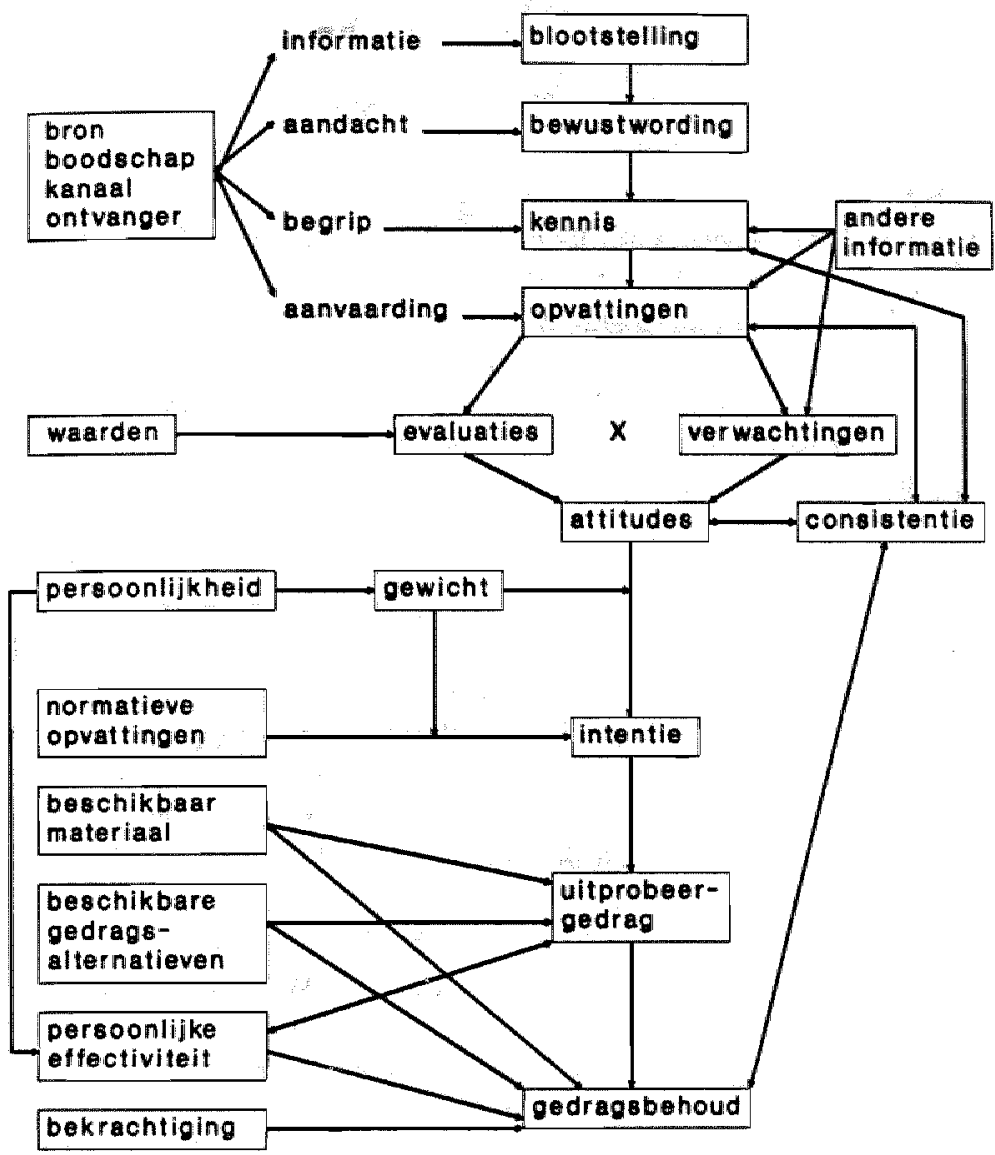

Figuur 5.8 Het integratie model van attitude en gedragsverandering. Bron: Flay et al., 1981, pag. 70.

De factoren genoemd onder a. en b. zijn ruimschoots in dit werk aan de orde gesteld. In de navolgende paragraaf zullen we onze aandacht 
concentreren op de punten c. en d. namelijk verandering via gedragservaring en bekrachtiging.

\subsection{De relatie attitude - gedrag}

Alle hier besproken modellen gaan er vanuit dat gedragsveranderingen het gevolg zijn van attitudeveranderingen. Recent werk in de sociale psychologie (Zanna en Fazio, 1982; Fazio, 1986, Sherman, 1980; Powell en Fazio, 1984; Kiesler, 1971; Bem, 1972) over de relatie attitude-gedrag veronderstelt dat attitudes niet noodzakelijkerwijze aan gedrag voorafgaan en dat er bijzondere omstandigheden nodig zijn, wil dat wel het geval zijn. Rokeach $(1968,1973)$ stelde dat verandering van attitudes niet of slechts tijdelijk tot verandering van gedrag leidt. Hij poogde middels experimenten aan te tonen dat permanente gedragsveranderingen alleen te bereiken zijn door het veranderen van waarden, die nauw met de persoonlijkheid van een individu verbonden zijn. Het veranderen van waarden leidt tot verandering van attitudes en gedrag. Het beïnvloeden van attitudes en gedrag heeft volgens Rokeach betrekkelijk weinig zin, omdat daarmee geen zekerheid verkregen wordt dat ook de waarden veranderen. Katz en Kahn (1967) suggereren dat (slechts) bepaalde attitudes die direct met het waardensysteem van een individu verbonden zijn, de $\mathrm{zgn}$ value expressive attitudes, duurzame invloed hebben op gedrag. Ook Fishbein en Ajzen houden een slag om de arm; de relatie attitudegedrag is een indirecte door tussenkomst van subjectieve sociale normen. Idem geldt dit voor de eigen-effectiviteitsbenadering van Bandura (1986), die de subjectieve verwachting van een individu omtrent de consequenties van gedrag en de inschatting van de competentie om gedrag wit te voeren als belangrijkste schakel in de relatie attitude-gedrag hanteert.

Deze voorbeelden illustreren dat veranderingen via attitudes niet zaligmakend zijn. Daarom is het nuttig na te gaan of er wellicht mogelijkheden zijn om (deels) het attitudeveranderingsconcept te omzeilen. Devine en Hirt (1989) lanceren twee strategieën die in voorlichtingscampagnes kunnen worden aangewend, namelijk (1.) overreding via de de boodschap: attitudes worden rechtstreeks beïnvloed door de boodschap, (A-B) en (2.) overreding via gedrag; attitudes worden indirect beinvloed door gedrag (B1- A-B2). Het voomaamste verschil tussen beide strategieën betreft de bron van 
informatie waardoor de attitude wordt gevormd, namelijk de boodschap van de communicator of de eigen ervaring. Bij overreding via de boodschap wordt de voorlichtingsboodschap geconstrueerd in de verwachting dat het bericht dwingend genoeg zal zijn om te leiden tot een positieve attitude, die op haar beurt weer zal leiden tot positief gedrag ten opzichte van een bepaald object. De in dit hoofdstuk beschreven modellen zijn te beschouwen als overreding via de boodschap. Bij overreding via gedrag wordt getracht om de ontvangers eerst bepaald gedrag te laten vertonen; als dit positief ervaren wordt zal vervolgens attitudeverandering optreden, hetgeen na verloop van tijd zal resulteren in stabiel gedrag ten opzichte van het object. In het model van Flay neemt het uitprobeergedrag een voorname plaats in. De vraag dringt zich nu op hoe voorlichters gedrag kunnen bewerkstelligen zonder dat eerst een attitudeverandering heeft plaatsgevonden. Allereerst denken we dan aan de sociale leertheorie, die deels gebaseerd is op modelling en transfertraining. In de reclamewereld wordt van dit modellingsprincipe veel gebruik gemaakt om mensen te overtuigen. Hierbij wordt vaak gezinspeeld op identificatie met een aantrekkelijke/geloofwaardige bron. In paragraaf 4.2 hebben we reeds gerefereerd aan Ray die stelt dat bewustwording en attitude(-verandering) niet alleen aan gedrag vooraf kunnen gaan maar er ook het gevolg van kunnen zijn. Hij stelt de ordening afhankelijk van de betrokkenheid van de ontvanger bij de boodschap, de mogelijke alternatieven en de ervaring en kennis van de ontvanger. Op de wisselwerking tussen attitudes en gedrag wordt ook door Festinger (1957) gewezen: in het streven naar cognitieve consistentie is eerder gedrag van invloed op de latere attitude. Ook kunnen we lering trekken uit de heuristiek. Waarschijnlijk de meest relevante heuristische regel om de doelgroep te laten toegeven is de reciprociteitsregel: als iemand je een gunst bewijst, dan ben je verplicht een dienst terug te doen. Heuristische regels bieden echter geen garantie voor herhaald gedrag (Devine en Hirt, 1989). Belangrijk is dan de vindingrijkheid waarmee ervoor gezorgd kan worden dat dit incidentele gedrag vertaald wordt in positieve attitudes.

De zelfperceptietheorie van Bem (1972) stelt dat personen hun attitudes afleiden van geobserveerde gedragingen. Deze theorie vormt de basis van veel "compliance-technieken". Een voorbeeld daarvan is de voet-tussen-de-deur-techniek, namelijk het verschijnsel dat mensen eerst overgehaald worden met een klein verzoek (bijvoorbeeld een donatie van 5 gulden); daarna zijn ze over het algemeen bereid om 
ook aan een forser verzoek te voldoen. Verklaringen voor dit verschijnsel richten zich op veranderingen, die ontstaan zijn in de zelfperceptie van mensen. Wie gevolg geeft aan een klein verzoek, ziet zichzelf als sociaal-bewust persoon die waardevolle zaken steunt. Als gevolg van deze processen kunnen mensen attitudes herleiden van hun gedrag en gaan ze zich vervolgens overeenkomstig de nieuwe attitudes gedragen. (Pallak, Cook en Sullivan, 1980; Ronis, Yates en Dirscht, 1989).

Ook de grondbeginselen van operante conditionering zijn toepasbaar om gedrag op te wekken. Herhaaldelijk is aangetoond dat operante conditionering implicaties heeft voor de waarschijnlijkheid van herhaling van gedrag en voor de vorming van attitude ten aanzien van het object van gedrag. Immers, we houden eerder attitudes vast die beloning opleveren en verwerpen attitudes die leiden tot afstraffing. De keuze die een voorlichter kan maken uit deze strategieën, is bij lange na niet eenvoudig. $\mathrm{Zij}$ is afhankelijk van het gewenste resultaat, het onderwerp, de doelgroep, etc.

Devine en Hirt (1989) stellen dat wanneer mensen voldoende gemotiveerd zijn om de informatie op te nemen en te verwerken, het bericht een grote persoonlijke relevantie bezit en wanneer sterke argumenten worden aangedragen, voorlichting door middel van de boodschapsstrategie het meest geschikt is. Wanneer de persoonlijke relevantie laag is, zou een op gedrag gebaseerde strategie de voorkeur verdienen. Deze feiten stemmen nagenoeg overeen met de bevindingen van Sherif (1979) die de mate van ego-involvering aanmerkt als belangrijkste gedragsvariabele.

Attitudes die gevormd zijn op basis van rechtstreekse gedragservaring met attitude-objecten, hebben een grotere voorspellende waarde dan attitudes, die gevormd zijn op basis van verwerkte informatie. Deze bevindingen worden ondersteund door ervaringsgegevens uit de marketing sector; fabrikanten geven potentiële kopers de gelegenheid gedragservaring op te doen met hun produkt middels bijvoorbeeld een proeftijd ("niet goed, geld terug") of het verstrekken van gratis monsters. Overigens moet hierbij wel vermeld worden dat de meeste advertentiecampagnes beide strategieën tegelijkertijd toepassen. 


\subsection{Slotbeschouwing}

In dit hoofdstuk hebben we een aantal courante modellen de revue laten passeren die direct of in aangepaste vorm bruikbaar zijn voor intentionele voorlichting. Het meest bekende model is het informatieprocesmodel van McGuire, dat in oorsprong bestond uit zes fasen en uitgegroeid is tot een raamwerk van twaalf stappen die doorlopen moeten worden om tot gedragsbehoud te geraken. Het model heeft vandaag de dag veel aan actualiteit ingeboet; veel van de de huidige inzichten uit de sociale psychologie vinden we er niet meer in terug. Desondanks blijft het een waardevol raamwerk voor de planning van massamediale voorlichtingscampagnes. Het model geeft duidelijk aan welke stappen de voorlichter moet zetten teneinde zijn campagnes naar een acceptabel succes te loodsen. McGuire heeft de onafhankelijke en afhankelijke variabelen die een rol spelen in het communicatieproces in een matrix bij elkaar gebracht. We hebben deze matrix beperkt tot de zogenaamde 12 stappen; een beschrijving van de afhankelijke variabelen is om een aantal redenen achterwege gelaten. Nog afgezien van het feit dat een diepgaande beschrijving van deze variabelen dit boekwerk uit zijn band zou doen springen, is de belangrijkste reden dat de afzonderlijke factoren die van invloed zijn op de afhankelijke variabelen, niet volledig, vaag of deels achterhaald zijn. Geinteresseerden in deze materie hebben er meer baat bij om specifieke literatuur te raadplegen. Voor een algemeen overzicht verwijzen we naar Damoiseaux (1988). De matrix van McGuire, waarin op de horizontale lijn de afhankelijke variabelen (bron, kanaal, boodschap, ontvanger en bestemming) zijn weergegeven en op de verticale lijnen de verschillende fasen in het voorlichtingsproces worden beschreven, heeft als bedoeling om de huidige stand van zaken weer te geven met betrekking tot het onderzoek op het gebied van attitudeverandering. Bij een eerste kennismaking oogt de matrix vrij logisch, maar degene die een poging waagt om de matrix concreet in te vullen behoeft het kluwen van Ariadne. Veelal gaat men in de fout door de respectievelijke afhankelijke en onafhankelijke variabelen afzonderlijk aan elkaar te relateren waardoor in totaal 60 cellen ontstaan. McGuire benadrukt juist de interacties tussen de verschillende variabelen/cellen. Anders geformuleerd, de onafhankelijke variabelen dienen in onderlinge samenhang aan de verschillende fasen gekoppeld te worden. 
De theoretische fundering van de communicatie/overredingsmatrix put McGuire uit een breed arsenaal van theorieên. We hebben er reeds gewag van gemaakt dat in de literatuur nauwelijks aan dit overzicht gerefereerd wordt. McGuire heeft naar onze mening af en toe een aantal buitennissige kunstgrepen moeten toepassen om het geheel van theorieën in een overzicht samen te vatten of heeft naarstig gezocht om het overzicht te completeren. Voor zover dat binnen ons bereik lag, dat wil zeggen voorzover de aangegeven theorieën door McGuire beschreven zijn, hebben we getracht ze te concretiseren voor de voorlichtingspraktijk. We zullen hieronder de belangrijkste consequenties voor de planning van voorlichting weergeven.

- De voorlichter moet duidelijk de context aangeven waarin de boodschap begrepen moet worden.

- De boodschap dient geformuleerd te worden in termen van het gewenste resultaat.

- Het tonen van voorbeeldgedrag uit de directe omgeving is essentieel.

- De voorlichting dient het idee te geven dat de vrijheid van mensen uitgebreid wordt in plaats van ingeperkt.

- Mogelijke barrières in het uitvoeren van gedrag kunnen beslecht worden door te wijzen op het aanleren van vaardigheden.

- De voorlichting dient erop gericht te zijn de eigen ervarings/belevingswereld uit te breiden; een verbodsbenadering is uit den boze.

- De voorlichtingsboodschap dient mensen gevoelig te maken voor inconsistenties.

- Het gewenste gedrag dient voldoende uitzicht te bieden op (concrete) beloning.

- De voorlichting dient gericht te zijn op probleemoplossing door de doellgroep.

- Een waarschuwende, belerende benadering sorteert averechtse effecten.

- De boodschap dient in wisselende modaliteit en langdurig herhaald te worden.

- Het aanbevolen gedrag dient tegemoet te komen aan het streven van de mens naar persoonlijke prestatie en attractiviteit.

- De voorlichtingsboodschap moet gelegenheid tot identificatie geven.

- Voorlichtingscampagnes dienen te appelleren aan het verantwoordelijkheidsgevoel. 
- De voorlichter dient ervoor te zorgen dat mogelijkheden voor positieve terugkoppeling in de interventie zijn ingebouwd.

Terloops merkt McGuire op dat voornoemde theorieën elk een deelaspect van de motivatie verklaren. In deze zin zijn de consequenties die uit de theorieën voortvloeien, op te vatten als voorwaarden om aan de meest elementaire verlangens van het publiek tegemoet te komen. Naar onze opvatting zijn de verschillende fasen van het model te beschouwen als condities volgens welke het beïnvloedingsproces doorlopen moet worden. Aan de bezwaren die aan het informatiemodel kleven, wordt (groten)deels tegemoet gekomen door het model van Kok Dit model verkeert nog in een embryonaal stadium omdat de mate van invloed van de diverse factoren (alleen de belangrijkste zijn genoemd!) niet vermeld zijn. De ideeën van Kok verdienen meer specificatie om ze voor massamediale campagnes aan te wenden. Het Elaboration-Likelihoodmodel van Petty en Cacioppo dwingt bewondering af door de volumineuze hoeveelheid research waarop dit model gegrondvest is. Het model voegt echter betrekkelijk weinig toe aan nieuwe inzichten voor massamediale toepassing. Dit is wel het geval met het model van Flay. Naar onze opvatting geeft Flay het complexe massamediale beinvloedingsproces overzichtelijk weer waarbij duidelijk wordt aangegeven welke factoren een rol spelen bij het streven naar veranderingen op gedragsniveau. Flay benadrukt dat massamediale campagnes gunstige resultaten boeken indien rekening gehouden wordt met: (a.) het ontwikkelen van vaardigheden benodigd om het gewenste gedrag uit te voeren; (b.) informatieverschaffing over verschillende gedragsalternatieven; (c.) stimulering van de interactie met het publiek (bijvoorbeeld door andere voorlichtingsmaterialen in de campagne te betrekken); (d.) aanvulling met en ondersteuning van interpersonale communicatie; (e.) mobilisatie of herstructurering van gemeenschappelijke middelen. Aan het slot van dit hoofdstuk vestigen we summier de aandacht op de relatie attitudegedrag. Het is niet onze bedoeling geweest om daar het verlossende woord over te spreken. Wel hebben we aangegeven dat deze relatie consequenties heeft voor de te volgen strategie. 



\title{
Hoofdstuk 6 Het pretesten van
}

\section{voorlichtingsmateriaal}

\author{
6.1 Inleiding \\ 6.2 Noodzaak van pretesten \\ 6.3 Voorwaarden voor pretesten \\ 6.4 Voordelen van pretesten \\ 6.5 Beperkingen van pretesten \\ 6.6 Inhoud van de pretest \\ 6.7 De testroute \\ 6.8 Methoden van pretesten \\ 6.9 Slotbeschouwing
}

\subsection{Inleiding}

Als er een gevalideerde methode zou bestaan om boodschappen op hun effectiviteit te testen, dan zouden we allengs te maken hebben met een schier eindeloze reeks van zaligmakende kassuccessen, tophits, bestsellers, etc..

Zo'n toverformule bestaat niet.

De meeste boodschappen worden of op goed geluk of op geleide van het vakmanschap van professionele communicatoren verstuurd. Ofschoon we - zelfs na een gedegen pretest - geen waarborgen kunnen verkrijgen over de uitwerking van de boodschap, is het toch zeker de moeite waard de boodschap vooraf te toetsen aan een aantal criteria die als voorwaarden gelden om de boodschap een optimale kans van slagen te geven conform de wensen van de voorlichter. In 
de volgende paragrafen wordt aandacht geschonken aan de voor- en nadelen, de noodzaak en de inhoudelijke componenten van pretesten. We introduceren een testroute, een systematische werkwijze om het rendement van pretesten te verhogen. Tot slot geven we een overzicht van de meest courante methoden van pretesten.

Aan pretesten van voorlichtingsmateriaal wordt in de praktijk doorgaans weinig aandacht besteed. Hier zijn verschillende oorzaken voor aan te wijzen: 1 . er is een gebrek aan kennis hoe men het precies moet doen; 2 . men overschat de eigen competentie ten aanzien van linguistische vaardigheden; 3 . men onderschat de tijd die nodig is om professioneel te pretesten, men heeft er doorgaans in de planning geen geld en tijd voor uitgetrokken; 4 . men is te veel gefixeerd op de inhoudelijke criteria; 5. men is niet overtuigd van het nut van pretesten.

Pretesten is een verzamelterm voor diverse onderzoeksmethoden, die gericht zijn op het opsporen/corrigeren van fouten en het vroegtijdig ophelderen van (eventuele) onduidelijkheden in voorlichtingsprodukten. Daarnaast bieden diverse pretestmethoden de mogelijkheid om de communicatieboodschap te optimaliseren. Het behoedt voor kapitale blunders wanneer men op grote schaal materialen gaat verspreiden. Pretesten is weliswaar arbeidsintensief, maar de moeite die men zich getroost, levert op den duur veel profijt op. In het geval van audiovisuele producties kan pretesten weleens onaangename financiële consequenties hebben, als achteraf blijkt dat het produkt de toets der kritiek niet kan doorstaan. Dit laatste pleit er des te meer voor om naast een zorgvuldige compositie van de boodschap - zich rekenschap te geven van de mogelijkheid dat het product vór het op de markt verschijnt nog gecorrigeerd of aangepast moet worden.

Pretesten is een vorm van formatieve evaluatie om vroegtijdig en systematisch reacties van de doelgroep en deskundigen te verzamelen over bedoelde en onbedoelde gevolgen van de communicatieboodschap. Pretesten is dus een middel om na te gaan of de communicatieboodschap bijdraagt aan de verwezenlijking van de interventiedoelstelling; het optimaliseert de kans op effectiviteit. Pretesten biedt echter geen garantie voor succes. 
Het pretesten van voorlichtingsmateriaal

\subsection{Noodzaak van pretesten}

De opvatting dat er een lineaire relatie (input=output) bestaat tussen de intentie van de zender en het effect bij de ontvanger, is allang achterhaald. Werd er vroeger van uitgegaan dat de ontvanger een willoos en passief individu was, thans gaat men er in de communicatietheorie vanuit dat de ontvanger een weldenkend individu is dat onder bepaalde omstandigheden en onder speciale condities informatie toelaat en verwerkt. Wil een boodschap daadwerkelijk invloed kunnen uitoefenen, dan is het noodzakelijk dat ze opgemerkt en begrepen wordt. Attentie voor en het begrijpen van de boodschap zijn absolute voorwaarden voor de verwerking van de informatie. Atkin (1981) stelt dat de belangrijkste reden voor het mislukken van voorlichtingscampagnes gezocht moet worden in de fase van blootstelling, interesse en begrijpen. De manier waarop mensen informatie verwerken wordt ten dele bepaald door de samenstelling van de boodschap en ten dele door de omstandigheden waarin zij ontvangen wordt (Huisman, 1987). Wat het eerste betreft is de boodschap onderworpen aan drie selectie-mechanismen, die aan ontvangerszijde een beslissende rol vervullen, te weten: selectieve blootstelling, selectieve perceptie en selectieve retentie (zie ook hoofdstuk 7). De selectie-mechanismen hebben gemeen dat de subjectieve definitie van de situatie, zoals die door een persoon wordt gezien of ervaren, bepaalt in welke mate de ontvanger de informatie toelaat, hoe hij de informatie interpreteert en hoe hij die in zijn geheugen wil opslaan.

Cuilenburg en Noomen (1984) brengen een verfijning aan in de verklaring waarom eenzelfde bericht bij ontvangers verschillende reacties teweeg brengt. $\mathrm{Zij}$ onderscheiden twee categorieën, te weten: a. communicatie-afhankelijke predisposities, dat wil zeggen kenmerken van de ontvanger die direct betrekking hebben op de boodschap, de zender of het kanaal, bijvoorbeeld de geloofwaardigheid van de bron; b. communicatie-onafhankelijke predisposities, dat wil zeggen de biografische kenmerken die de ontvanger meer of minder ontvankelijk maken voor media-gebruik, bijvoorbeeld ouderen hebben een ander mediagedrag dan jongeren. Dit onderscheid is voor pretesten van belang, omdat de eerstgenoemde predisposities aanwijzingen kunnen bevatten over de wijze waarop de boodschap gecomponeerd moet worden. De tweede groep geeft inzicht in de wijze waarop en met welk medium de doelgroep benaderd moet worden. Van Woerkum (1982) plaatst de predisposities meer in het kader van de 
mediumkeuze en het segmenteren van doelgroepen. Hij maakt onderscheid tussen algemene predisposities, dat wil zeggen kenmerken van de ontvanger die aanwezig zijn voordat de boodschap hen bereikt en situationele predisposities die verwijzen naar kenmerken van de ontvangers in een bepaalde context. Volgens Van Woerkum zijn predisposities "sociaal verankerd", hetgeen impliceert dat ze in zekere mate gebonden zijn aan biografische kenmerken van (delen van) het publiek. Een niet te veronachtzamen moeilijkheid bij het opsporen en segmenteren van doelgroepen op basis van predisposities is dat ze zich aan directe waarneming onttrekken en vaak met elkaar verstrengeld zijn.

De noodzaak van pretesten wordt stringenter als:

- men over weinig kennis van de voor te lichten populatie beschikt. Met kennis doelen we in dit geval op bijwoorbeeld beliefs, attitudes, wensen en verwachtingen, ervaringen ten aanzien van een bepaald probleem;

- men in onzekerheid verkeert ten aanzien van de diffusie en adoptie van de voorlichtingsboodschap binnen de doelpopulatie.

- men, om welke reden dan ook, niet in de gelegenheid is geweest om een zorgvuldige gedragsdeterminantenanalyse uit te voeren;

- men weinig weet over het tijdstip en de plaats waarop de doelgroep ontvankelijk is voor informatie;

- men twijfelt aan of een slechte inschatting kan maken van de barrières, die de relatie tussen intentie en gedrag kunnen blokkeren.

- de aard van het probleem veel weerstand zal oproepen of controversieel is.

- met de interventie aanzienlijke kosten gemoeid zijn.

\subsection{Voorwaarden van pretesten}

In het algemeen worden in de communicatiewetenschappen drie verschillende informatiebegrippen gehanteerd, namelijk syntactische informatie (de opeenvolging van signalen, bijvoorbeeld het schrift), semantische informatie (de betekenis die aan signalen gehecht wordt of de kennisoverdracht) en de pragmatische informatie (hierbij gaat het om de reactie van de ontvanger op de verkregen informatie of om het effect dat de communicatieboodschap sorteert). Het gebruik van 
de verschillende soorten informatie in het communicatieproces wordt in figuur 6.1 in beeld gebracht.

Er is pas sprake van geslaagde communicatie als de syntactische informatie gelijk is aan de semantische en pragmatische informatie. In de communicatietheorie is daarvoor de term isomorfie gereserveerd, dat wil zeggen dat de betekenis die de zender bedoeld heeft, wordt overgenomen door de ontvanger. Communicatiestoornissen ontstaan voornamelijk, wanneer hiaten optreden in het proces van encoderen en decoderen van de informatie.

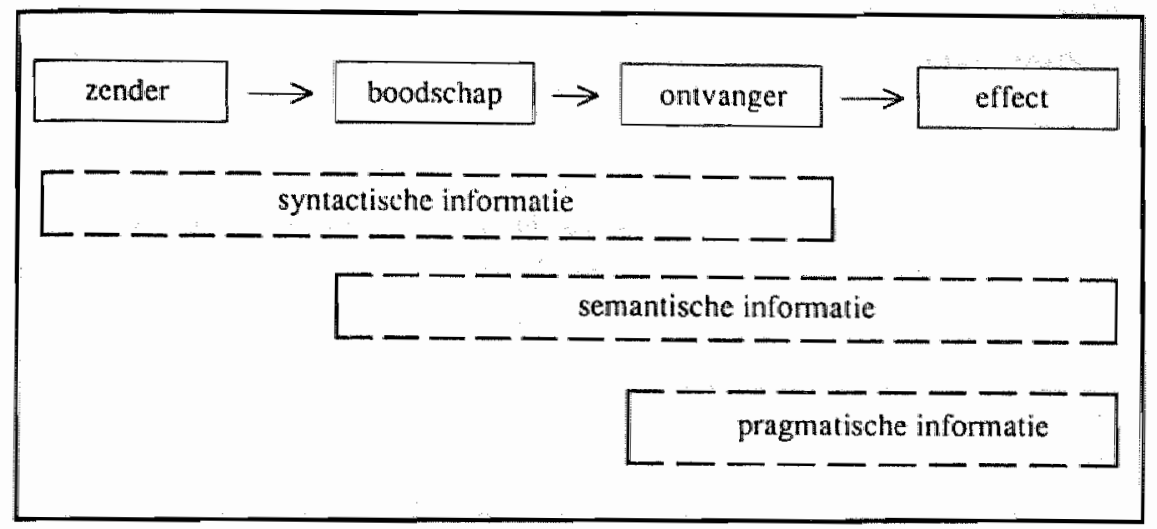

Figuur 6.1 Syntactische, semantische en pragmatische informatie in het communicatieproces.

We kunnen twee doelstellingen van pretesten onderscheiden:

1. Nagaan of de boodschap wordt gedecodeerd conform de intentie van de zender (van syntactische informatie naar semantische informatie);

2. Nagaan of de boodschap wordt verwerkt conform de bedoelingen van de zender (van semantische informatie naar pragmatische informatie). 
Teneinde de kans op verwezenlijking van deze doelstellingen te optimaliseren, moet voldaan worden aan de volgende essentiële voorwaarden:

- de boodschap dient niet alleen opgemerkt en begrepen te worden, maar ook voldoende prikkels te bevatten om de informatie toe te passen;

- de boodschap dient steeds vanuit de optiek van de ontvanger te worden gecomponeerd dat wil zeggen dat de zender zich moet verplaatsen in de huid van de ontvanger (het zogenaamd empathisch vermogen). De zender moet dus van tevoren precies nagaan wat er onder de doelgroep leeft, in welke mate men gemotiveerd is, of hoe men een bepaalde problematiek ervaart. Op deze manier kan men voorkomen dat uit de boodschap verkeerde gevolgtrekkingen of vreemde associaties kunnen worden getrokken;

- de zender moet van tevoren nagaan of zijn boodschap wel voldoende interessant is. Dit kan met behulp van het ezelsbruggetje: is het leuk om te weten, is het goed om te weten, is het praktisch om te weten? Het loont de moeite om aan het opvolgen van de boodschap een gratificatie te verbinden in de vorm van een materiële of immateriêle beloning.

\subsection{Voordelen van pretesten}

Alvorens op grote schaal te gaan produceren moet er een beoordeling in kwalitatief opzicht plaatsvinden; het streven is immers gericht op het behalen van een zo hoog mogelijk rendement met de communicatieboodschap.

- Met pretesten kan een inschatting gemaakt worden van de mogelijke barrières, die het gewenste gedrag verhinderen.

- Met pretesten kan men niet alleen een inschatting maken van de intentie of de uitwerking op de overtuiging, maar bovenal zich voorbereiden op mogelijke alternatieven.

- Met pretesten kan men inzicht verwerven in de juistheid en volledigheid van de boodschap.

Men moet zich echter geen overdreven voorstellingen maken van de effectiviteit van schriftelijk informatiemateriaal. Allereerst moet men het bezien naar zijn functionaliteit, dat wil zeggen als hulpmiddel bij informatie-overdracht, en naar zijn effectiviteit: het materiaal reikt 
doorgaans niet veel verder dan de fase van oriëntatie in het voorlichtingsproces (zie hoofdstuk 5).

\subsection{Beperkingen van pretesten}

In het voorafgaande hebben we een lans gebroken om pretesten te beschouwen als een geintegreerd deel van de interventie. Een veel gehoord bezwaar tegen een grondige pretest is de kans dat - wanneer de resultaten negatief uitvallen - er tijdverlies optreedt. Echter, indien het materiaal met de vuilnisman mee gegeven kan worden vanwege het gebrek aan kwaliteit, dan heeft de pretest zijn waarde dubbel en dwars bewezen. De lering die we hieruit moeten trekken is dat er bij de planning rekening gehouden moet worden met het feit dat pretesten de implementatie ernstig kan vertragen.

Pretesten geeft slechts indicaties: er is geen waarborg voor het bereiken van het uiteindelijke gewenste effect. Dit heeft onder andere te maken met het feit dat pretesten doorgaans plaatsvindt in een artificiële situatie. Het ontbreekt vaak aan tijd om de doelgroep op te sporen die op dat tijdstip ontvankelijk is voor de voorlichting. De ontvanger wordt als het ware in een onrealistische situatie gemanoeuvreerd om een oordeel te geven. Er kan gemakkelijk vertekening optreden omdat de doelgroep gedwongen blootgesteld wordt aan de informatie. Deze gedwongen blootstelling heeft nog een ander bezwaar, namelijk het feit dat de attentiewaarde van de boodschap niet achterhaald kan worden. Daar staat als voordeel tegenover dat mensen kritischer het materiaal beoordelen, waardoor vroegtijdig fouten kunnen worden opgespoord. De eerlijkheid gebiedt te zeggen dat pretesten in de regel duidelijke aanwijzingen oplevert hoe het niet moet en relatief weinig concrete suggesties hoe het dan wel moet. In paragraaf 6.8 komen we hier nader op terug. De waarde van pretesten kan het best getraceerd worden in de oriëntatiefase van het voorlichtingsproces door het meten van de afhankelijke variabelen aandacht en begrip. We moeten ons dus beperken tot onmiddellijke effecten. Over de effecten op langere termijn kunnen we slechts uitspraken doen met betrekking tot de intentie tot handelen. Of de intentie tot handelen op den duur wordt omgezet in daadwerkelijk gedrag, blijft buiten het gezichtsveld.

Aan pretesten kleven grosso modo ook nog statistische bezwaren. In de regel zal men zich bij het pretesten beperken tot een bescheiden 
steekproef. Een geringe omvang van de steekproef kan het statistisch verwerken van de gegevens ernstig bemoeilijken.

Uit kostenoverwegingen zal men vaak de voorkeur geven aan een dummy, waarin zo nauwkeurig mogelijk de definitieve vorm wordt nagebootst. Toch moeten aan een dummy hoge eisen worden gesteld. Men gaat weleens in de fout door alleen de tekst te laten beoordelen. Het sublimeren van vorm en inhoud bepalen uiteindelijk de kwaliteit van het product. Afgezien van allerlei typografische en vormtechnische elementen moet men niet voorbijgaan aan de waarde van illustraties in schriftelijk voorlichtingsmateriaal. Illustraties (tekeningen, modellen, schema's, foto's, etc.) kunnen de overtuigingskracht van een boodschap verhogen, maar kunnen de boodschap ook verluchtigen of relativeren. Illustraties zijn onmisbaar, als het gaat om zaken die moeilijk tekstueel zijn uit te leggen. Door complexe zaken schematisch te visualiseren kan men niet alleen winnen aan helderheid, maar bovendien wordt veelal kostbare ruimte uitgespaard.

Van Oortmarssen en Kok (1985) concluderen dat illustraties in de voorlichting een gunstige werking kunnen hebben op het trekken en vasthouden van de aandacht: in de oriëntatiefase van het voorlichtingsproces werken ze als een visuele magneet. Dat illustraties bij een tekst voor een beter leerresultaat zorgen, wordt door de empirie voldoende gesteund (Dwyer, 1967; Duchastel, 1981). Het is niet aan te raden om tekst en illustratie afzonderlijk te beoordelen. Meestal ontlenen zij hun kracht aan hun onderlinge samenhang.

Pretesten betreft veelal het beoordelen van een kunstmatig veractualiseerde boodschap. Men hoeft echter niet te volstaan met het opnemen/registreren van beoordelingen. Er zijn voldoende mogelijkheden te benutten om meer informatie te vergaren die kan bijdragen aan het optimaliseren van de boodschap. Men kan immers heel direct vragen welke informatie men gemist heeft of welke extra informatie men zou willen hebben.

Omdat we te maken hebben met niet real-life condities, is inschatting van het uiteindelijk effect moeilijk. Het optreden van ruis door de werking van interveniërende variabelen kan de gewenste gang van zaken vertroebelen.

Wellicht ten overvloede merken we nog op dat het gebruilk van schriftelijk materiaal aan functionaliteit wint, als het gebruikt wordt als aanvulling op dyadische en massamediale communicatie. Als hulpmiddel kan het ook goed gebruikt worden bij de overdracht van 
veel informatie-eenheden. Gebruikt men schriftelijk materiaal als zelfstandig medium, dan mag men door de bank genomen niet veel meer verwachten dan een toename van kennis of het vergroten van inzicht (Van Assema eri. Damoiseaux, 1987).

\subsection{Inhoud van de pretest}

Een veel gebruikte methode om voorlichtingsmateriaal te testen is de Health Message Testing Service (HMTS). Deze standaardtest is zowel toepasbaar op schriftelijk als op audiovisueel materiaal. De HMTS is een korte, semi-gestructureerde vragenlijst, die gemakkelijk voor verschillende onderwerpen is aan te passen.

In deze methode is een aantal criteria geformuleerd dat bij pretesten als maatstaf gebruik wordt bij de beoordeling van voorlich-

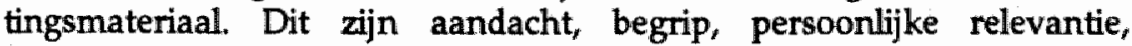
betrouwbaarheid, aanvaardbaarheid en bijwerkingen of ongewenste gevolgen.

We zullen in het kort aangeven wat deze criteria inhouden.

Aandacht. Wordt de boodschap opgemerkt? Is ze attractief en uitnodigend om te lezen? Wordt de aandacht vastgehouden?

Begrip. Is de informatie leesbaar, is ze begrijpelijk, is ze logisch geordend. Is duidelijk welke handelingen er verwacht worden, is de boodschap overtuigend?

Persoonlijke relevantie. Is de boodschap van toepassing op de geselecteerde doelgroep, herkent de doelgroep de problematiek? Kunnen de ontvangers zich identificeren met de beschrijving. Gaat er voldoende motiverende werking van de boodschap uit?

Betrouwbaarheid. Is de informatie geloofwaardig, wordt er mogelijk getwijfeld aan deskundigheid, is er voldoende overtuigingskracht?

Aanvaardbaarheid. Is de boodschap realistisch, is de boodschap voldoende concreet? Zijn er voldoende gedragsalternatieven? Past de boodschap in het handelingsrepertoire van de doelgroep. Worden de vaardigheden beschreven die nodig zijn om het gewenste gedrag uit te voeren. Zijn de barrières die moeten worden genomen om het gedrag uit te voeren voldoende omschreven?

Bijwerkingen of ongewenste gevolgen. Is er voldoende rekening gehouden met de selectiemechanismen van de ontvangers? Is de ruis 
onder controle? Heeft men voldoende aandacht geschonken aan gedragsalternatieven die niet gewenst zijn?

\begin{tabular}{|c|c|c|c|}
\hline & $\begin{array}{l}\text { High } \\
\text { score ronge } \\
(\%)\end{array}$ & $\begin{array}{l}\text { Average } \\
\text { score range } \\
(\%)\end{array}$ & $\begin{array}{c}\text { Low } \\
\text { score range } \\
(\%)\end{array}$ \\
\hline $\begin{array}{l}\text { Attention/recall } \\
\text { (Percent remembering seeing message } \\
\text { after one exposure) }\end{array}$ & 41 or higher & $30-40$ & 29 or lower \\
\hline $\begin{array}{l}\text { Main ideal } \\
\text { (Percent remembering main idea } \\
\text { of message after one exposure) }\end{array}$ & 36 or higher & $25-35$ & 24 or lower \\
\hline $\begin{array}{l}\text { Worth remembering } \\
\text { (Percent indicating 'yes') }\end{array}$ & 76 or higher & $60 \ln 75$ & 59 or lower \\
\hline $\begin{array}{l}\text { Personally relevant } \\
\text { (Percent indicating message is } \\
\text { talking to someone like themselves) }\end{array}$ & 66 or higher & $50-65$ & 49 or lower \\
\hline $\begin{array}{l}\text { Anything confusing } \\
\text { (Percent indicating "yes') }\end{array}$ & 9 or lower & $10-20$ & 21 or higher \\
\hline Believable & 91 or thigher & $75-90$ & 740 - lower \\
\hline Well done & 66 or higher & $50-65$ & 49 or lower \\
\hline Convincing & 71 or highter & $55-70$ & S4 or lower \\
\hline Informative & 76 or higher & $60-75$ & 59 or lower \\
\hline Made its point & 91 or higher & $75-90$ & 74 or lower \\
\hline Interesting & 66 or higher & $50-65$ & 49 or lower \\
\hline Pleasant & 66 or higher & $50-65$ & 49 or lower \\
\hline
\end{tabular}

Figuir 6.2 Standaardlijst voor het interpreteren van respons op pretestvragen.

Het is zonder meer waar dat bovengenoemde criteria tot de belangrijkste maatstaven horen om voorlichtingsmateriaal te beoordelen. Als checklist bij de compositie van boodschappen zijn ze goed bruikbaar. Er kleven toch enige bezwaren aan deze lijst. Op de eerste plaats is er 
geen systematische werkwijze aangegeven. Op de tweede plaats zijn de gehanteerde criteria niet volledig; zo wordt er bijwoorbeeld voorbijgegaan aan een technische beoordeling (bijvoorbeeld de grootte van het lettertype). Tot slut ontbreekt een kwaliteitsoordeel over de vormgeving en lay-out. Romano (1984) heeft op grond van een groot aantal pretesten een standaardlijst met scores opgesteld die als een handleiding kan dienen bij de interpretatie van de gevonden resultaten. Het betreft scores van vragen, die doorgaans in iedere pretest aan de orde worden gesteld.

\subsection{De testroute}

In het navolgende introduceren wij een route voor het samenstellen en pretesten van voorlichtingsmateriaal. Met deze testroute proberen we zoveel mogelijk tegemoet te komen aan professionele eisen als systematiek, planmatigheid en doelgerichtheid. De route is geconstrueerd op basis van eigen onderzoek (Damoiseaux en De Jongh, 1988 ) en geïnspireerd door het massamediaal werkplan van Van Woerkum (1982).

In het voorafgaande hebben we duidelijk aangegeven dat het pretesten een geïntegreerd onderdeel van de interventie dient te zijn. De testroute vangt dus feitelijk aan bij het formuleren van de doelstelling van de interventie. Als de finale doelstelling van de interventie geformuleerd is, zal deze geoperationaliseerd moeten worden in subdoelen of communicatiedoelen. De communicatiedoelen worden onderworpen aan de afweging welke methode en/of medium het meest geschikt is om de doelen te realiseren en de boodschap over te brengen. Vervolgens wordt nauwgezet de boodschap geformuleerd, die dan concreet vorm wordt gegeven in een tekst, bijvoorbeeld een inventarisatie van alle relevante feiten en argumenten en eindigend met conclusies. In ons onderzoek (zie hoofdstuk 8) was de doelstelling van de interventie "het voorkomen van skiletsels" en de boodschap: "Laat uw skibindingen afstellen met behulp van een testapparaat door de vakman". Op basis van de verzamelde gegevens wordt een concept-tekst gecomponeerd. Deze leggen we voor aan het kritische oog van inhoudsdeskundigen en toetsen die vervolgens aan voorlichtingskundige criteria. Bij de inhoudsdeskundigen wordt nagegaan of de inhoud voldoet aan de criteria van relevantie, verificatie en falsificatie, logica en argumentatie. Het gaat hier dus met name om de 


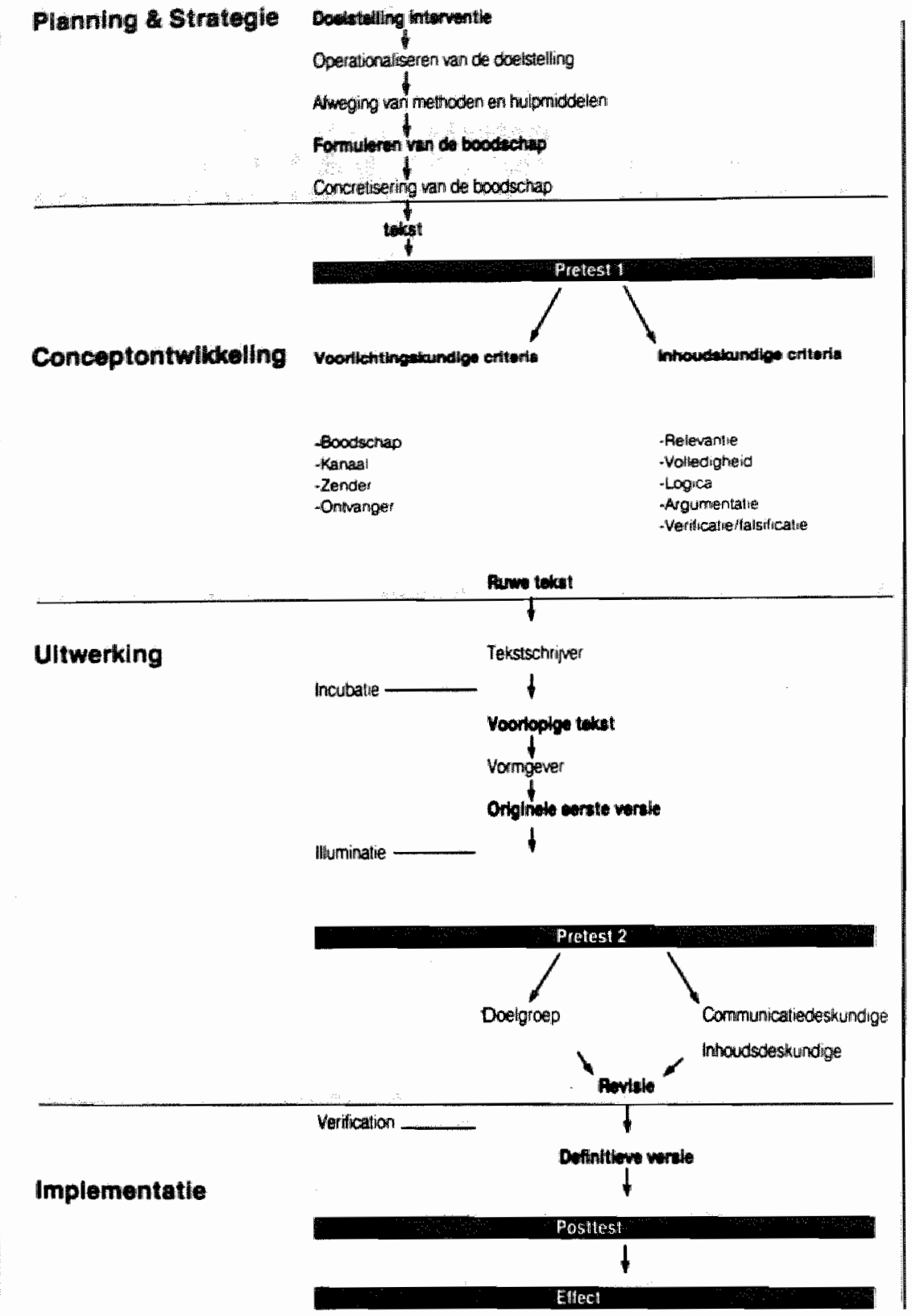

Figuur 6.3 De pretestroute. 
vraag of de informatie juist is en of de inhoud van de boodschap verantwoord is. Leidt bijvoorbeeld het afstellen van de bindingen tot een reduktie van de letsels? Onder inhoudsdeskundigen rekenen we bijvoorbeeld mensen die hun vak goed beheersen, praktijkwerkers met veel ervaring, of mensen die als opinieleiders fungeren voor de doelgroep. Op basis van de bevindingen van de inhoudsdeskundigen zal de voorlichter de inhoud moeten toetsen aan die factoren die mogelijk van invloed zijn op het uiteindelijk resultaat van het communicatieproces. Ook zal hij beslissingen moeten nemen over de vorm waarin de boodschap gegoten wordt. De voorlichter zal zelf de voorlichtingskundige criteria (zender, boodschap, ontvanger, kanaal) moeten toetsen. Deze zijn uitvoerig door McGuire (1975) beschreven.

In het kort zullen we willekeurig een aantal punten noemen die niet aan de aandacht van de voorlichter mogen ontsnappen. Hij zal zich bijvoorbeeld rekenschap moeten geven van dominante factoren aan zenderzijde (attractiviteit, geloofwaardigheid, deskundigheid, macht). Ook zal hij terdege rekening moeten houden met de boodschapsvariabelen. Deze variabelen zijn relatief makkelijk veranderbaar en moeten aangepast worden aan de doelgroep die hem voor ogen staat. Hij zal duidelijke keuzen moeten maken ten aanzien van de benadering die hij voorstaat (bijvoorbeeld een rationele versus een emotionele benadering). Hij zal ook besluiten moeten nemen over het gebruik en de opbouw van argumenten, de hoeveelheid informatie, de toonzetting (bijvoorbeeld het al dan niet gebruiken van angstaanjagende voorlichting). Om deze beslissingen verantwoord te kunnen nemen, is het noodzakelijk zich te verdiepen in de waarden, normen, wensen, verwachtingen en de belevingswereld van de potentiële ontvangers (zie ook paragraaf 4.8). Hij zal bijvoorbeeld moeten nagaan wat de vigerende mening is ten aanzien van een bepaald onderwerp of probleem, hij zal moeten weten in welke mate de populatie geïnvolveerd is en zal een inschatting moeten maken van de mogelijke discrepantie die het voorlichtingsbericht oproept.

Zowel de voorlichtingskundige als de inhoudelijke toetsing geven nu voldoende indicaties om de ruwe tekst samen te stellen. De ruwe tekst dient verwerkt te worden tot een professioneel communicatieprodukt. Indien we met de voorlichting de vooropgezette bedoeling hebben om te beïnvloeden, moeten er hoge eisen gesteld worden aan het communicatie-instrument taal. Het hanteren van de taal is vakwerk en vergt een perfecte schrijftechniek. Wij adviseren 
dan ook om dit werk ower te laten aan professionele copywriters: zij weten precies hoe ze de taal moeten hanteren om gelezen en begrepen te worden. Hieruit mag niet de conclusie getrokken worden dat het pretesten overbodig zou worden. Hoe minutieus men de boodschap ook samenstelt, men is er nooit zeker van hoe het publiek of segmenten daarvan, reageert. Roomer (1987) stelt dat het communicatieproduct een hechte eenheid is van verbale en visuele vormgeving, van verwoorden en verbeelden. De finale tekst moet vervolgens nog voorzien worden van een passende lay-out en verluchtigd met illustraties. $\mathrm{Nu}$ is de eerste originele versie klaar en kan deze onderworpen worden aan de tweede pretest. De originele versie wordt voorgelegd aan de doelgroep. Deze test, die mondeling, telefonisch of schriftelijk kan worden afgenomen, moet een redelijke omvang bestrijken, die afhankelijk is van de diversiteit en de omvang van de populatie zelf. In verreweg de meeste omstandigheden is het mondeling interviewen in een face-to-face situatie het meest geëigend. We komen hier zo dadelijk uitgebreid op terug.

In de regel heeft de steekproef, waarbij gestreefd moet worden naar een zo representatief mogelijke afspiegeling, een minimale omvang van 50 personen. Bij testen die men mondeling afneemt, kan men met minder respondenten volstaan. In face-to-face interviews kan men immers per respondent meer informatie vergaren. De resultaten van het onderzoek bij de doelgroep worden vervolgens weer voorgelegd aan de inhoudsdeskundigen en worden bezien in het licht van de eerder genoemde voorlichtingskundige criteria. Indien correcties noodzakelijk zijn, worden deze aangebracht en kan er een definitieve versie gemaakt worden. Het materiaal kan de deur uit.

\subsection{Methoden van pretesten}

Pretesten rekent men gewoonlijk tot het praktijkgericht onderzoek, dat will zeggen dat de uitkomsten van het onderzoek duidelijke resultaten dienen op te leveren die in de praktijk toepasbaar zijn. Bij praktijkgericht onderzoek gaat het niet zozeer om bewijzen en verklaringen, maar veeleer om aanwijzingen die bijdragen aan efficiency en effectiviteit. Deze normen nemen niet weg dat er getornd kan worden aan een aantal methodologische eisen, zoals validiteit, generaliseerbaarheid en betrouwbaarheid. Pretest-onderzoeken hebben doorgaans geen wetenschappelijke pretentie; in de voorlichtingskunde 
zijn de gepubliceerde studies die het aura van grote doorwrochtheid kunnen doorstaan op éen hand te tellen. In Nederland komt de wetenschappellijke inbreng aan de professionalisering van pretestonderzoek voornamelijk uit de de hoek van de linguistiek en de toegepaste taalwetenschappen. Pretestonderzoek - kwalitatief alsook kwantitatief - kent vele mogelijkheden, beperkingen en varianten. De keuze voor soort en vorm van pretestonderzoek is volgens Schumacher en Waller (1985) afhankelijk van:

- de beschikbare tijd;

- de bruikbaarheid van de resultaten;

- de doelstelling van opdrachtgevers/voorlichters;

- de beschikbare financiën;

- de reproduceerbaarheid;

- de validiteit.

De eerstgenoemde punten spreken voor zich, de laatste twee worden hier in het kort toegelicht. De validiteit wordt gewaarborgd door een goede operationalisering van de onderzoeksvraag: meten we inderdaad datgene wat we willen meten? De kwaliteit van de afzonderlijke vragen bepaalt uiteindelijk de kwaliteit van de totale pretest. Ook moet er op toegezien worden dat de meetprocedure zorgvuldig wordt uitgevoerd. De reproduceerbaarheid is afhankelijk van de mate waarin herhaalde metingen van hetzelfde concept dezelfde resultaten laten zien.

Ten aanzien van de reproduceerbaarheid wijzen diverse auteurs (Kreeft et al., 1982; Lentz, 1989) in navolging van De Groot (1961), op effecten die de betrouwbaarheid negatief kunnen beïnvloeden:

1. Het signifisch effect. Beoordelaars/respondenten verschillen in taakopvatting ten aanzien van het beoordelen van tekst. Zelfs na een grondige instructie hanteert men verschillende criteria.

2. Het halo-effect. In de beoordeling spelen irrelevante factoren een rol. Kennelijk kan een kenmerk waar men gevoelig voor is de scoretoekenning beïnvloeden. Lentz (1989) stelt dat beoordelaars/respondenten zich nogal gemakkelijk laten verleiden tot het vellen van een globaal oordeel over de tekst op grond van een kenmerk dat sterk in het oog springt, en andere tekstkenmerken daardoor negeren.

3. Het sequentie-effect. Beoordelaars/respondenten zijn geneigd hun oordeel te baseren op voorafgaande beoordelingen. Indien men na 
een aantal slechte paragrafen een matige paragraaf onder ogen krijgt, is men al snel geneigd deze als goed te beoordelen.

4. Persoonlijke neigingen. Zoals bijvoorbeeld extra kritisch zijn, mild oordelen, vermoeidheid e.d. spelen een rol bij de beoordelingen. Indien men een omvangrijk stuk moet beoordelen zal dat bij het eerste gedeelte zorgvuldig geschieden, maar naarmate men vordert zal de accuratesse afnemen.

5. Normverschuiving. Naarmate een beoordelaar/respondent vaker een beoordelingstaak moet uitvoeren, gaat hij routinematig handelen met het gevaar dat hij soms strenger, soms soepeler gaat beoordelen. Ook kan het zijn dat er verveling optreedt, waardoor andere aspecten meer nadruk krijgen.

6. Het contaminatie-effect. Onbewust kan de beoordelaar/respondent andere (persoonlijke) factoren in zijn beoordeling betrekken die met de toetsing als zodanig niets te maken hebben. Het kan bijvoorbeeld zijn dat een bepaalde ideologie of politieke voorkeur de beoordeling verminkt of dat men strenger/soepeler beoordeelt om zelf goede resultaten te behalen.

Van Woerkum (1982) onderscheidt twee categorieën methoden, namelijk de effectmeting en de beoordeling. Met de effectmeting bedoelt hij het registreren van die reacties die direct optreden nadat de respondent met de boodschap geconfronteerd wordt. Die onmiddellijke effecten behelzen:

a. contact met de boodschap;

b. kennisnemen van de boodschap;

c. begrijpen van de boodschap;

d. accepteren van de boodschap.

De indeling van Van Woerkum volgt de logische weg die McGuire in het verloop van het communicatieproces heeft uitgezet. Toch is het gepast om twee kanttekeningen te maken: alvorens men een boodschap kan begrijpen moet er eerst contact met de boodschap zijn. Dit contact met de boodschap is in het geval van pretesten doorgaans een gedwongen blootstelling; gevraagd of ongevraagd vindt er een confrontatie met de boodschap plaats. Met opvallendheidsmetingen zou men eventueel het effect van gedwongen blootstelling kunnen voorkomen maar dan verplaatst men het probleem naar een laboratoriumsituatie. Een tweede kanttekening sluit aan bij de ideeën van Schumacher en Waller (1985) die erop wijzen dat het gebruik van een 
tekst in hoge mate afhankelijk is van de context waarin de lezer kennismaakt met de tekst en het doel dat hij met de tekst voor ogen heeft.

Een van de belangrijkste doelstellingen van het pretesten is te achterhalen of men de tekst begrepen heeft. Vanuit de gedachte dat pretesten praktijkgericht onderzoek is, dringt zich als afgeleide doelstelling de vraag op hoe de kwaliteit van de tekst verbeterd kan worden. De kwaliteit van een voorlichtingstekst moet naar onze opvatting getoetst worden aan vier normen:

1. begrijpelijkheid en inzichtelijkheid;

2. bruikbaarheid;

3. empirische verifieerbaarheid;

4. toepasbaarheid.

Wil de boodschap conform de bedoeling van de zender tot resultaat leiden, dan is begrip een noodzakelijke voorwaarde. Begrip is niet zo eenvoudig te meten. Doorgaans wordt voor het meten van begrip een kennistoets afgenomen. Begrijpelijkheid en inzichtelijkheid gaan echter veel verder dan kennisvermeerdering; tot het cognitieve domein worden ook processen als assimilatie gerekend. Hierbij worden nieuwe ervaringen ingepast in de bestaande psychologische structuur. Ook accommodatie, dat wil zeggen de herwaardering van de psychologische structuur aan de hand van nieuwe feiten en ervaringen rekent men tot de cognities. Inzichtelijkheid heeft betrekking op de structuur en de presentatie van de informatie.

Bruikbaarheid is een betrekkelijk rekbare term; we verstaan eronder de mate waarin de informatie nieuw en interessant is, de gepercipieerde nuttigheid en de mate waarin de informatie als praktisch en handig wordt beschouwd. Van Woerkum (1982) heeft erop gewezen dat de aangeboden informatie empirisch verifieerbaar moet zijn. Op het eerste oog lijkt dit een open deur, maar we willen met klem benadrukken dat veronachtzaming van deze norm fnuikend is voor de geloofwaardigheid van de voorlichting. De adviezen die in de voorlichtingsboodschap vervat zijn, dienen op waarheid te berusten. De beloften, die er gedaan worden, behoren te worden ingelost. Het is jammer te moeten constateren dat aan deze norm veel te weinig aandacht wordt besteed. Zo wordt er bijvoorbeeld in de nationale campagne: "Blessures, blijf ze de baas", gesteld dat warming-up blessures kan voorkomen terwijl er geen emprirische data beschikbaar zijn die deze relatie bevestigen. Als laatste kwaliteitseis noemen we de 
toepasbaarheid van de informatie. Hiermee bedoelen we dat het publiek of de doelgroep iets met de informatie moet kunnen doen, deze toepassen in de eigen situatie. Dit veronderstelt dat de informatie realistisch moet zijn dat wil zeggen dat ernaar gestreefd moet worden dat ze optimaal ingepast kan worden in het gewone handelingsrepertoire. De uitvoering van de adviezen of voorschriften dient dus makkelijk en soepel te verlopen.

In het navolgende zullen we een aantal courante onderzoeksmethoden aan de orde stellen die aangewend kunnen worden om de voorlichtingsboodschap te optimaliseren en te corrigeren.

\section{a. De inhoudsanalyse}

Inhoudsanalyse wordt door Holsti (1969) gedefinieerd als:"...any technique for making inferences by objectively and systematically identifying specified characteristics of messages". Holsti stelt twee voorwaarden aan een wetenschappelijk gefundeerde inhoudsanalyse, namelijk objectiviteit en systematiek. Met objectiviteit duidt ze op de voorwaarde dat de onderzoeker vooraf moet vaststellen welke kenmerken van de boodschap dienen te worden geanalyseerd. Met systematiek wordt bedoeld dat de analyse op consistente en controleerbare wijze wordt toegepast. De inhoudsanalyse is bij uitstek geschikt voor de analyse van tekstkenmerken. De eenvoudigste vorm van de inhoudsanalyse beschrijft de communicatie-inhoud met behulp van een classificatieschema dat onafhankelijk is van de inhoud. De inhoudsanalyse van tekstkenmerken kent vele varianten, onder andere de contingency-analyse, de symbol-analyse, de performanceanalyse en de evaluative assertion-analyse. De contingency-analyse zoekt naar samenhang van associatief verbonden inhoudelijke kenmerken waarin attitudes verborgen zijn. De symbol-analyse richt zich op de in de boodschap voorkomende frequenties van waardedragende symbolen en de strekking daarvan. In de performance-analyse wordt de inhoud van de boodschap afgemeten aan een normatieve standaard, bijvoorbeeld de volledigheid van de boodschap. De evaluative assertion-analyse van Osgood richt zich op het evaluatieve karakter van teksten. Bij deze methode wordt niet alleen de richting van de attitudes met betrekking tot de inhoud gemeten, maar ook de intensiteit daarvan. Wij volstaan hier met een beknopte weergave van de diverse inhoudsanalytische methoden. Voor nadere details raadplege men de literatuur. 


\section{b. De cloze-procedure}

De cloze-procedure is een invultest voor zowel geschreven als gesproken teksten. Deze eenvoudige methode berust op het idee dat naarmate proefpersonen minder moeite hebben met het invullen van een ontbrekend woord de tekst als gemakkelijk geclassificeerd kan worden. In de tekst worden systematisch een aantal woorden vervangen door een spatieruimte van gelijke lengte, die de proefpersonen zelf moeten invullen. De cloze-procedure is een betrouwbaar meetinstrument. De begripsvaliditeit en predictieve validiteit van dit instrument zijn voor kritiek vatbaar.

\section{c. Leesbaarheidsformules}

Leesbaarheidsformules worden doorgaans gehanteerd om de moeilijkheidsgraad van een tekst vast te stellen. Jansen (1979) omschrijft een leesbaarheidsformule als een instrument waarmee men de leesbaarheid van teksten kan voorspellen op grond van de waarde die twee of meer linguistische variabelen in een fragment uit die teksten bezitten. Alle tot nu toe ontwikkelde leesbaarheidsformules hebben de vorm van een multipele lineaire regressievergelijking. De bekendste formule is de "reading-ease" van Flesch, die in het Nederlands bewerkt is door Douma en bekendheid geniet onder de term de "FleschDouma formule". De moeilijkheidsgraad wordt vastgesteld op basis van woord en zinslengte van teksten; hoe korter de woorden en de zinnen, hoe makkelijker de tekst is. Vooral Van Hauwermeiren (1975) heeft zich verdienstelijk gemaakt op het gebied van informatieve teksten. De validiteit van de door hem ontwikkelde formules is echter dubieus. Wellicht ten overvloede zij erop gewezen dat leesbaarheidstoetsen niet gelijk gesteld mogen worden met begrijpelijkheidstesten. Interessant in dit verband is het onderscheid dat Stewart (1985) aanbrengt in leesbaarheid en leesgemak: "While legibility is concerned with the physical details of the letter, word, and arrangement of words, readability is concerned more with ease of reading due to interest value or pleasantness, and ease of understanding or comprehesion due to the style of writing" (pag. 24-25). Zowel "legibility" als "readability" zijn essentièle voorwaarden voor begrip. 


\section{d. Hardopdenkprotocollen}

Volgens Jansen en Steehouder (1984) is de hardopdenk-analyse een geschikte methode om problemen die de lezer tegenkomt bij het doomemen van een tekst, op te sporen. De analyse gaat als volgt in zijn werk: de proefpersonen krijgen een tekst voorgelegd en moeten daarbij steeds meteen hardop zeggen wat zij denken. Deze zinnen of uitingen worden vervolgens afzonderlijk benoemd om op grond daarvan tot conclusies te komen over de mentale processen die zich bij de proefpersoon hebben afgespeeld. Aan deze methode kleven twee bezwaren, namelijk men weet niet zeker of datgene wat iemand denkt hetzelfde is als wat hij zegt. Ten tweede treedt de onderzoeker als filter op, in die zin dat hij de woorden en de uitingen weer moet interpreteren. Deze methode is dus geen feitelijke weergave van het denken, maar geeft wel indirecte aanwijzingen over het verloop van het denkproces. Jansen en Steehouder (1984) zijn op basis van empirisch onderzoek naar het gebruik van overheidsfolders, de mening toegedaan dat het afnemen van hardopdenkprotocollen een zeer vruchtbare methode van pretesten kan zijn.

\section{e. "Free-recall"- en samenvattingstoetsen}

Free-recalltoetsen dienen om na te gaan wat de proefpersonen van de tekst onthouden hebben. Doorgaans gaat het om het opsporen van informatie-elementen van kleine teksteenheden (proposities) of om het samenvatten van de kern van teksteenheden. Free-recalltoetsen meten niet of de tekst begrepen is. Daarvoor is volgens Anderson (1980) een semantische encodering nodig. Of er semantische encodering plaatsvindt, kan men achterhalen door het stellen van twee soorten vragen, namelijk parafrasevragen en getransformeerde parafrasevragen. Een letterlijke weergave van de tekst hoeft namelijk geen bewijs te zijn dat de tekst ook begrepen is. Bij parafrasevragen mag geen enkel letterlijk woord uit de oorspronkelijke tekst gebruikt worden. Getransformeerde parafrasevragen zijn gelijk aan parafrasevragen met dit verschill dat ook de ordening van de tekst kan verschillen. Wil men uitsluitend weten of de tekst onthouden is dan kan men ook gebruik maken van letterlijke vragen ("de vraag verschilt alleen van de tekst door invoeging van een vraagwoord en de weglating van het gevraagde element") en getransformeerde letterlijke vragen ("de vraag bevat belangrijke lexicale elementen uit de tekst zonder dat zinsneden uit de tekst volledig worden overgenomen") (Kreeft, Vroege en Zondervan, 1982 pag. 368-382). 
Hamaker (1978) geeft de voorkeur aan samenvatten als meettechniek boven free-recallprotocollen, omdat samenvatten meer inzicht verschaft in de weergave van de structuur van de tekst en de belangrijkste informatie.

\section{f. De performancetest}

De performancetest van Schumacher en Waller (1985) is een vergelijkend onderzoek waarin men de tekst ten aanzien van een aantal vorm- en inhoudskenmerken varieert. Op basis van recall- en beoordelingstesten kan men onderzoeken welke tekst het meest optimaal is. Deze methode leent zich goed om de meest geschikte stijldimensies te vinden. Steehouder et al. (1979) onderscheiden de volgende stijldimensies:

- uiterlijke structuur (nadrukkelijk versus onopvallend);

- moeilijkheid (eenvoudig versus complex);

- exactheid (vaag versus precies);

- informatiedichtheid (wijdlopig versus bondig);

- aantrekkelijkheid (levendig versus droog);

- afstandelijkheid (formeel versus informeel).

Ook is het goed mogelijk om met een aantal vormaspecten en de visuele presentatie te experimenteren, bijvoorbeeld de lay-out, lettertype, gebruik van illustraties etc..

De toegankelijkheid van een tekst wordt bepaald door de zogenaamde structuuraanduiders (zoals bijvoorbeeld kopjes, chapeau, leesadviezen, advance organizers en overzichten). Met de hierboven beschreven test is het mogelijk om de mate van toegankelijkheid vast te stellen.

\section{g. De tekstanalyse}

Bij de tekstanalyse richt men zich op het bestuderen en ontleden van tekstelementen en probeert men relaties tussen de verschillende tekstelementen te ontdekken. Zo wordt bijwoorbeeld geprobeerd zicht te krijgen op hoe de argumenten zijn opgebouwd en hoe een betoog gestructureerd is. Het analyseren is een solistische activiteit van de onderzoeker en wordt uitgevoerd zonder de doelgroep erbij te betrekken. Gezien de grote validiteitsproblemen concludeert Lentz (1989) dat de tekstanalyse weinig zal bijdragen aan de evaluatie van teksten. De voorlichter zal met de resultaten weinig kunnen doen, omdat ze niet gerelateerd zijn aan en afgestemd zijn op de doelgroep. Meer dan 
algemene inzichten in de structuur van de tekst en de opbouw van het betoog mag men van een tekstanalyse niet verwachten.

\section{h. De functionele analyse}

Functionele analyse is een vorm van taalbeheersingsonderzoek waarin communicatieve processen worden bestudeerd vanuit hun functionele context. Het is dus uitdrukkelijk niet de bedoeling om de communicatieve elementen geisoleerd te benaderen. Men moet ze, vanuit de context waarin ze gebruikt worden, aan nader onderzoek onderwerpen. Lentz (1989) omschrijft een functionele analyse van een tekst als volgt: "Een activiteit waarmee de voorlichter of onderzoeker verheldert welke communicatieve handeling met een tekst beoogd wordt, wie de adressaat is van de tekst, wat het thema van de tekst is en welke verandering de tekst in de situatie van de adressaat geacht wordt te bewerkstelligen". Gezien het feit dat er bij de functionele analyse ernstig rekening gehouden dient te worden met de context waarin de communicatie zich ontwikkelt, wordt de functionele analyse vooraf gegaan door een institutionele analyse. Met een institutionele analyse wordt bedoeld een overzicht te vervaardigen van de verschillende betrokkenen in het voorlichtingsproces. De mate van het belang en/of het aandeel dat zij hebben in de voorlichting wordt bepaald aan de hand van een aantal criteria die van situatie tot situatie kunnen verschillen. Naarmate de context concreter is, kunnen ook specifiekere criteria ontwikkeld worden. De institutionele analyse komt nagenoeg overeen met wat doorgaans als diagnose-fase of kenweg (Van Woerkum, 1985) wordt aangeduid. Het belang en/of het aandeel dat de betrokkenen hebben, wordt uitgedrukt in claims. De bundeling van deze claims verschaft inzicht in de randvoorwaarden en geeft het kader aan waarin het communicatieve doel geformuleerd moet worden.

\section{i. De signifische begripsanalyse}

De signifische begripsanalyse stamt uit het brein van De Groot en Medendorp (1986). Het is een heuristische methode (heuristisch opgevat als niet altijd, maar vaak zinvol en effectief toepasbaar) om moeilijke, vage begrippen waarvan - veelal - tegenstrijdige definities worden gegeven te ontmaskeren, bijvoorbeeld begrippen als "welzijn", "pijn", "energie", "discriminatie" etc.. Begripsverwarring is voornamelijk toe te schrijven aan verkeerd taalgebruik; onnodige en ongewenste vaagheid en onnodige en ongewenste inperking van de betekenissen 
van woorden, in het bijzonder van belangrijke begrippen. De Groot en Medendorp (1986, pag 19) spreken van "zinsverduistering", een manier van omgaan met taal waarmee verhullende of vervagende effecten worden bereikt. Het effect wordt volgens hen bereikt bij:

"a. onduidelijk jargon

b. hoogabstracte begrippen zonder contextuele specificatie,

c. begrippen met grote onbepaaldheidszone en/of meerzinnigheid,

d. met name ook begrippen-met-een-nimbus,

e. begrippen die geacht worden te "bestaan" (reifficatie) en/of te ageren (antropomorfisering, personificatie),

f. specifiek theoriebelaste begrippen,

g. die in complexe, lange zinnen,

h. met onverbindbare wendingen erin,

i. resulteren in beweringen die principieel niet toetsbaar zijn."

Het zal weinig betoog behoeven dat het effect van zinsverduistering fnuikend is voor adequate voorlichting. De signifische begripsanalyse is als pretest goed te gebruiken, bijvoorbeeld bij het samenstellen van bijsluiters bij medicijnen. Voor nadere details verwijzen we naar De Groot en Medendorp (1986).

\section{j. Pretesten uit reclame-onderzoeken}

Wie verwacht dat het pretesten, als vorm van praktijkgericht onderzoek, in de reclamewereld tot grote bloei is gekomen, vergist zich schromelijk. De gangbare pretesten zijn op én hand te tellen. Veel aandacht wordt in de reclamewereld geschonken aan opvallendheidsmetingen, waarbij de mate van herinnering als afhankelijke variabele wordt gehanteerd. In het reclame-onderzoek zijn 3 soorten pretest-onderzoek courant: 1. CD-onderzoek (Creatieve Dynamiek); 2. De Buy-test; 3. Magnitude Estimation.

CD-onderzoek is een zeer eenvoudig kwalitatief onderzoek waarbij via een gesloten tw-circuit een interview-situatie wordt geobserveerd. De belangrijkste doelstelling is om na te gaan hoe het betreffende reclame- materiaal door de respondenten wordt gepercipieerd. Voorts wil men inzicht verwerven in het keuze- en koopproces van de betreffende goederen. De onderzoekspopulatie betreft ongeveer 20 a 30 personen.

De Buytest is een gestandaardiseerde methode, die berust op halfgestructureerde interviews, waarbij ongeveer 130 respondenten betrokken zijn. 
Hel doel van de Buy-test is inzicht te verkrijgen in de cognitieve en affectieve effecten van de reclame-uiting. Voorts probeert men te achterhalen welke factoren in het geding zijn ten aanzien van het nemen van beslissingen.

De Magritude Estimation gaat uit van de idee dat mensen bij het vergelijken en beoordelen van stimuli een numerieke schaal hanteren. De Magnitude Estimation is een schaaltechniek die is ontwikkeld voor het meten van de intensiteit van zintuiglijke waarnemingen. Zo wordt bijwoorbeeld de helderheid van licht of de zoetheid van frisdrank uitgedrukt in een getal. De respondenten krijgen voor het onderzoek een intensileve training waarin hun wordt geleerd een bepaald getal aan een bepaalde eigenschap te verbinden. De ervaringen die men met deze methode heeft opgedaan, zijn niet bekend. Momenteel is men in de reclamewereld druk doende met de ontwikkeling van nieuwe technieken zoals semiollogische analyse en fysiologische metingen.

\section{k. De "content response code"}

Deze methode, in Nederland de plus-en-min methode genoemd, is een beoordelingsmethode om na te gaan wat de sterke en zwakke kanten van een tekst zijn. De respondenten worden uitgenodigd om - op basis van richtlijnen van de onderzoeker - een tekstdeel (content unit) te voorzien van plussen bij stukken/delen die men positief waardeert en minnen bij delen/stukken die men negatief waardeert. In een nagesprek met de onderzoeker wordt aan de respondent een nadere toelichting gevraagd op de beoordeling. Van Woerkum stelt dat dit nagesprek zowel individueel als groepsgewijs kan plaatsvinden. Vroom (1987) heeft dit nagesprek vervangen door een schriftelijke variant waardoor meer respondenten aan de test kunnen meedoen. De resultaten met deze schriftelijke variant waren bevredigend. Vroom wijst er echter op dat een zorgvuldige instructie onontbeerlijk is. Vanwege haar eenvoud en het feit dat er niet veel tijd mee gemoeid is, kan deze methode door de voorlichter zelf uitgevoerd worden. De methode is niet zaligmakend; er kleven nogal wat bezwaren aan. Afgezien van de validiteit levert deze pretest alleen inzicht in de onmiddellijke effecten in de zin van suggesties voor verbetering van de boodschap. Deze methode geeft geen uitsluitsel over de vraag of de boodschap begrepen is en de ontvanger zal handelen conform de intentie van de zender. Bovendien moeten de respondenten in staat zijn om hun bevindingen goed te verbaliseren. 


\section{De "signalled stopping technique"}

Aan de proefpersonen wordt een tekst voorgelegd met het verzoek deze te lezen in het bijzijn van de onderzoeker. Zodra de proefpersoon iets opvalt in de tekst, moet hij even stoppen. De onderzoeker noteert de plek waar het stoppen plaatsvindt of, wanneer de onderzoeker niet aanwezig is, wordt de respondent geacht een notitie te maken. Het idee achter deze methode is dat stoppen een signaal is dat er iets met de tekst aan de hand is (men begrijpt het niet, raakt in verwarring, vindt iets interessant, etc.). $\mathrm{Na}$ afloop van het lezen komt de onderzoeker op de haperingen terug om zodoende de reden van het stoppen te achterhalen. Het maken van notities bij deze methode zou als bezwaarlijk kunnen worden aangemerkt. Immers de schakel van lezen naar schrijven levert meer problemen op dan de schakel van lezen naar spreken (Lentz, 1989).

\section{m. De seminar-methode}

Deze methode is vergelijkbaar met focusgroepsinterviews en is bedoeld om meer zicht te krijgen in de achterliggende motieven van bepaalde oordelen over de tekst. Van de groepsdiscussie, al dan niet aan de hand van stellingen, worden opnamen gemaakt, die later tot protocollen worden verwerkt. Of deze methode voldoende garanties biedt voor de beoordeling van de kwaliteit van de tekst is twijfelachtig. Wellicht kan de onderzoeker met de feedback iets verbeteren, maar er spelen bij deze groepsgewijze aanpak vele sociaal-psychologische mechanismen een rol die gemakkelijk tot een vertekend beeld kunnen leiden. De betrouwbaarheid is zeer problematisch. Focusgroupinterviews zijn wel geschikt om gedetailleerde informatie te verkrijgen van de doelgroep.

\section{n. Observaties}

Er zijn talrijke methoden ontwikkeld om het leesgedrag van proefpersonen te observeren. Meestal vindt dergelijk onderzoek plaats in laboratoriumsituaties of is er speciale apparatuur nodig om de bevindingen te registreren. Voor pretesten zijn deze methoden, met uitzondering van de one-way-screen observatie, niet bijster interessant, omdlat ze alle zeer arbeidsintensief zijn, erg duur en te weinig gericht op het gebruik in een realistische context. 


\subsection{Slotbeschouwing}

In het voorafgaande hebben we de mogelijkheden en moeilijkheden van het pretesten behandeld. We hebben een aantal methoden de revue laten passeren, die aangewend kunnen worden om de boodschap te verbeteren of die geschikt zijn om een oordeel over de kwaliteit van de boodschap te krijgen. Wellicht ten overvloede zij er op gewezen dat de beoordelingsmethoden ook aanwijzingen kunnen bevatten voor het verbeteren van de tekst. Het onderscheid tussen de methoden is niet altijd even scherp. Waar het om gaat is dat er een analyse-instrument gekozen wordt dat voldoende betrouwbaar en valide is en dat het wordt toegepast in situaties waar het optimaal rendeert. In de vorige paragrafen hebben we een lans gebroken voor de noodzaak van pretesten. In onze opvatting kan niet volstaan worden met uitsluitend de doelgroep als object van studie te kiezen. Ook zullen inhouds- en communicatiedeskundigen bij de pretest betrokken moeten worden. Pretesten dient naar onze mening niet op de valreep plaats te vinden, maar integraal te worden opgenomen in de fase van conceptontwikkeling. 


\section{Hoofdstuk 7 De effecten van massamediale voorlichting}

7.1 Inleiding

7.2 Nadere begripsbepaling van effectiviteit

7.3 Beoogde versus niet beoogde effecten

7.4 Typologie van media-effecten

7.5 Directe versus indirecte effecten

7.6 Effecten van massamediale campagnes

7.7 Nederlandse massamediale campagnes

7.8 Slotbeschouwing

\subsection{Inleiding}

Wie zich verdiept in de literatuur over de effectiviteit van de massamedia begeeft zich op glad ijs. Er is een schier onuitputtelijke voorraad aan meningen, studies en overzichten; zij bieden nauwelijks enig houvast om een algemene conclusie te trekken. Het beantwoorden van de vraag naar de effectiviteit van de massamedia is per definitie onmogelijk. Het zou in feite een generaliserende uitspraak zijn over alle modaliteiten van massacommunicatie; dit impliceert eenvoudigweg dat men de televisie, de radio, de krant, het affiche bij de tramhalte en de mededeling op het bierviltje over éen kam scheert. Effectiviteit dient men te beschouwen in het licht van de vooraf geformulleerde doelstellingen.

Het feit dat in de loop der tijd vele onderzoekers enorme hoeveelheden tijd en energie gestoken hebben in het opsporen van effecten, 
moet er toch op wijzen dat we te doen hebben met een fascinerend fenomeen. Sinds de Eerste Wereldoorlog heeft men met niet aflatende inzet geprobeerd om de effecten van massamedia in kaart te brengen. Het laatste woord over de invloed van de media is nog lang niet gezegd. Dat is natuurlijk ook niet zo verwonderlijk, want de aard en omvang van de massamedia zijn in de loop van de tijd sterk aan verandering onderhevig geweest. Daar komt bij dat we met een expansilef fenomeen te maken hebben.

Sprak men in de jaren dertig nog over de almacht van de media, thans moeten we, bij de huidige stand van de wetenschap, ontnuchterend vast stellen dat over de invloed van de media weinig concensus bestaat. Begin jaren zeventig was men nogal negatief gestemd over de effectiviteit van de media. Mensen uit de praktijk, voorlichters, journalisten, marketing-managers, reclame-mensen hebben dit echter niet beaamd. De meesten daarvan waren er vast van overtuigd dat de media wel degelijk effectief zijn. Deze opvatting resulteert dan in vraagstellingen als : "Hoe is het te verklaren dat de industrie biljoenen guldens besteedt aan reclame-budgetten ?", "Hoe is het te verklaren dat mensen het merendeel van hun vrije tijd doorbrengen met het consumeren van media-boodschappen $7^{m}$, "Hoe is het te verklaren dat er radicale veranderingen in de maatschappij plaatsvinden als we de werking van de massamedia buiten beschouwing laten?" Afdoende verklaringen voor bovengestelde vragen liggen niet direct voor het grijpen - althans geen antwoorden die direct te herleiden zijn tot de werking van de massamedia - maar zij dwingen wel tot een nadere bezinning over begrippen als invloed, macht en effectiviteit. De laatste 10, 15 jaar wordt wat genuanceerder gedacht over de invloed van de media. Thans wordt wat meer geloof gehecht aan de betekenis van de media in bijvoorbeeld het bevestigen van bepaalde rolpatronen, zoals mannelijk en vrouwelijk gedrag, in vooroordelen ten aanzien van minderheden, etc.. Men spreekt in dit verband weleens over de onderstroom in het massamediale aanbod, dat is al datgene wat niet direct opgemerkt wordt, maar wel systematisch in vele massamediale uitingen terug te vinden is zonder dat we er ons direct van bewust zijn (Katz, 1980). 


\subsection{Nadere begripsbepaling van effectiviteit}

MCQuail (1983) verklaart de verwarring over het al dan niet effectief zijn van de media uil het feit dat de massamedia een welhaast onuitputtelijk aantal onderwerpen aan de orde stellen, waarvan een groot gedeelte bepalend is voor het sociaal-economisch functioneren (weerberichten, geldkoersen, advertenties, openbare mededelingen, etc.). Gezien de enorme diversiteit aan onderwerpen die de afzonderlijke media dagelijks voor het voetlicht halen, is het volgens $\mathrm{McQuail}$ niet juist om te spreken van de effecten van de media; dit impliceert dat de functionaliteit en het gebruik van de verschillende media van hetzelfde gehalte zijn. Roberts en Maccoby (1985) zijn van mening dat de term "media-effecten" uitsluitend gebruikt mag worden als deze direct gekoppeld is aan het medium in kwestie. Er is een wereld van verschil tussen de effecten van de gedrukte media en de electronische media. Binnen de electronische media zijn ook aanmerkelijke verschillen; naarmate men binnen de verschillende media meer differentieert, treden er meer verschillen op in aard en omvang. De materie wordt nog complexer wanneer men in een interventie de verschillende media met elkaar combineert.

Indien we het begrip effectiviteit niet nader operationaliseren kunnen we stellen dat zowel de optimisten als de pessimisten ten aanzien van de effectiviteit van de massamedia een evenredige portie van het gelijk kunnen opeisen. Het aloude adagium van "ergens wel en ergens niet" is zeker van toepassing op de effectiviteit van de massamedia, zoals treffend is weergegeven door Berelson in 1948: "Some kinds of communication, on some kinds of issues, brought to the attention of some kinds of people under some kinds of conditions, have some kinds of effects ". De meeste effectenstudies op het gebied van de massacommunicatie hebben betrekking op de processen, die zich aan ontvangerszijde afspelen als gevolg van blootstelling aan de media. Maletzke (1963) brengt een tweedeling aan in deze processen. Hij rekent tot effecten: a. alle processen die zich afspelen in de postcommunicatieve fase als gevolg van massacommunicatie en $b$. alle processen die zich afspelen in de communicatieve fase, als gevolg van de gerichtheid van de ontvanger op een bepaalde mediumboodschap. Een soortgelijk onderscheid treffen we bij Van Woerkum (1982) aan. Hij spreekt van onmiddellijke effecten, dat wil zeggen een directe respons op het communicatieve aanbod en effecten op termijn, 
waarmee bedoeld wordt veranderingen, die zich naderhand manifesteren op het niveau van kennis, attitude en gedrag. Voor intentionele voorlichting zijn de effecten op termijn van belang, maar dit neemt niet weg dat we de onmiddellijke effecten kunnen verwaarlozen. Zij vormen de basiswoorwaarden voor de effecten op termijn. Atkin (1981) schrijft het mislukken van vele campagnes toe aan het uitblijven van onmiddellijke effecten, zoals bijvoorbeeld blootstelling aan en begrijpen van de voorlichtingsboodschap.

De effectiviteit of invloed van de media kan men vanuit verschillende disciplines en vanuit verschillende perspectieven bekijken. In de voorlichting is het gebruikelijk om de effecten te onderscheiden naar veranderingen in kennis, houding en gedrag. Een oppervlakkige terugblik in de historie van massacommunicatief onderzoek laat zien dat in den beginne vooral de aandacht gericht was op de effecten ten aanzien van gedragsverandering. Eind jaren zestig concludeerde men dat het belangrijkste effect gezocht moest worden in de richting van attitudeverandering (Katz, 1980; Chaffee, 1977). Hedentendage bekommert men zich voornamelijk om effecten op cognitief niveau. Dit wil echter geenszins zeggen dat attittude- en gedragseffecten in de vergetelheid zijn geraakt. Thans gaat men ervan uit dat er eerst veranderingen in cognities moeten optreden vooraleer er sprake kan zijn van attitude- en gedragsverandering. Attitudeveranderingen ten gevolge van massamediale input voltrekken zich traag; ze zijn meer het gevolg van aanslibbing (accretion) en erosie dan van plotselinge en geplande verandering. Roberts en Maccoby (1985) vatten de effecten van massamedia als volgt samen.

1. Attitude-effecten zijn noch noodzakelijk noch doeltreffend om gedrag te beinvloeden.

2. Cognitieve effecten zijn noodzakelijk en doeltreffend om het corresponderende gedrag te beïnvloeden.

3. Cognitieve effecten op zich zijn belangrijke gevolgen van massamediale beïnvloeding.

\subsection{Beoogde versus niet-beoogde effecten}

Aangezien voorlichting doorgaans opgevat wordt als een opzettelijke poging om te beïnvloeden, is het zinvol onderscheid aan te brengen conform de intentionaliteit van de zender, dat wil zeggen dat men de effecten kan onderverdelen in beoogde en niet-beoogde effecten. 
Voorlichtingskundige interventies zijn niet alleen gericht op veranderingen bij het individu, maar missen ook hun uitwerking niet op de samenleving als geheel. Dit impliceert dat bepaalde bedoelingen van de zender (kunnen) leiden tot de gewenste reacties bij het publiek, dat op zijn beurt weer invloed doet gelden op de samenleving als totaal. Stel bijvoorbeeld dat een tv-uitzending daadwerkelijk sterke invloed uitoefent op het kiezersgedrag, dan heeft dit gevolgen voor de samenstelling van het kabinet.

Gerbner (1956) verdeelt effecten in twee typen, namelijk effecten (effects) conform de bedoeling van de zender en effecten (consequences) die optreden als gevolg van het al dan niet realiseren van de gewenste doelstellingen. De laatste worden in de literatuur aangeduid met "gevolgen". Ze zijn, bedoeld of niet bedoeld, gewenst of niet gewenst, het resultaat van een door media veroorzaakte verandering. Het zal duidelijk zijn dat deze gevolgen zich niet zozeer op individueel niveau doen gevoelen alswel op het niveau van de samenleving. Door de gevolgen achter het optreden van effecten te traceren hebben we het tijdsperspectief geintroduceerd: in de massacommunicatieve literatuur wordt onderscheid aangebracht in effecten op de korte (0-6 dagen), middellange (7-30 dagen) en lange termijn (een maand of meer na het verzenden van de boodschap). Media-effecten zijn pas op hun ware merites te schatten als het tijdsperspectief bij de beoordeling betrokken wordt. Studies op het gebied van innovaties hebben het belang van de tijdsdimensie uitdrukkelijk aangetoond (Rogers, 1983). Zo speelt de factor tijd een belangrijke rol bij het ontvangen van informatie, de duur van de blootstelling aan de informatie en de tijdspanne die verloopt tussen het verwerken van de informatie en het optreden van reacties (Davis en Lee, 1980).

Van Cuilenburg en Noomen (1984) hanteren de tijdsdimensie door onderscheid aan te brengen in de fase van ontvangst van de informatie en de fase van interpretatie en verwerking van de informatie. Dit onderscheid is nagenoeg hetzelfde als dat van Maletzke en Van Woerkum (1982). Bandura (1977) heeft erop gewezen dat het vergaren van of blootstelling aan informatie en het verwerken daarvan twee verschillende processen zijn. Weliswaar is het meten van verwerking alleen mogelijk als de informatie ook ontvangen is, maar het uitblijven van een reactie mag niet geweten worden aan niet succesvolle ontvangst. Dit impliceert dat ten aanzien van de twee onderscheiden fasen verschillende factoren hun invloed doen gelden. In de fase van ontvangst zijn selectiviteitsmechanismen als blootstelling en perceptie 
in het geding terwill in de fase van verwerking factoren als groepsnormen, cognitieve dissonantie en betrokkenheid (ego-involvement) relevant zijn. In figuur 7.1 zijn de factoren schematisch weergegeven

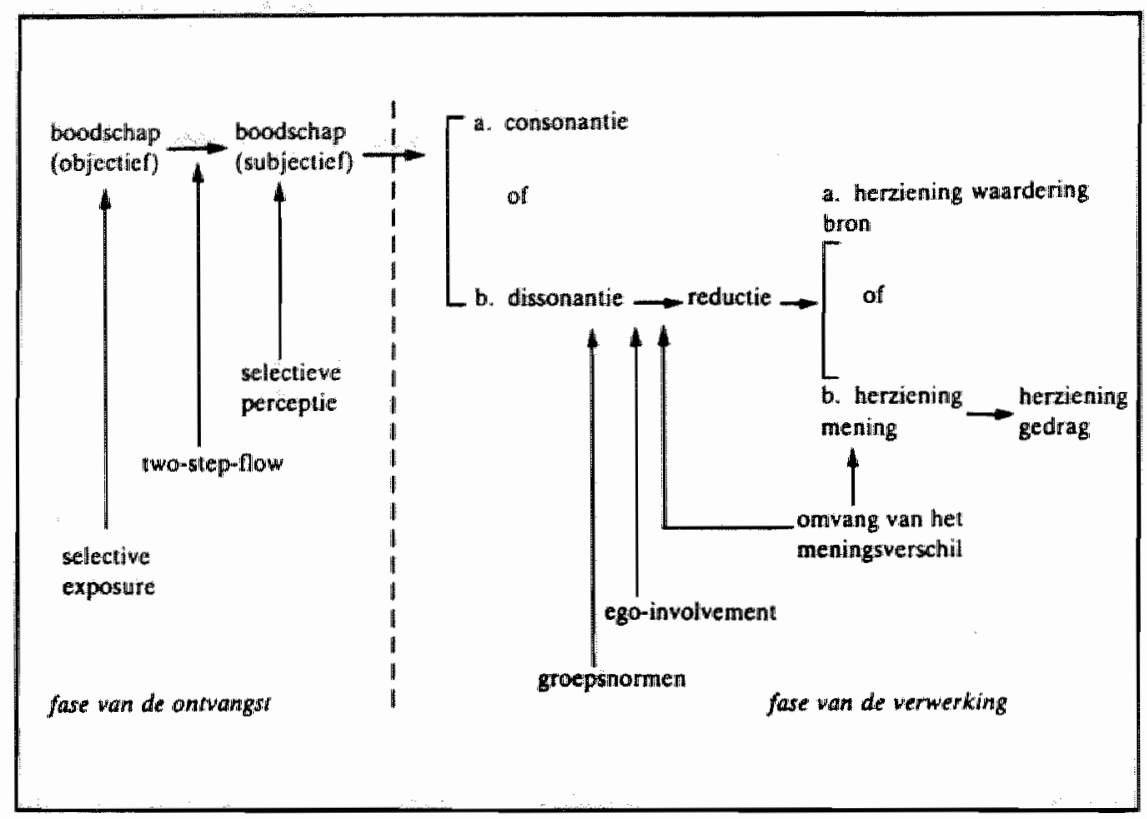

figuur 7.1 Massamedia en beïnvloeding; een overzicht van factoren. Bron: Van Cuilenburg en Noomen, 1984, pag. 159.

De meeste effectstudies concentreren zich op de beoogde effecten op kennis, attitude en gedrag. Deze kunnen betrekking hebben op de individuele persoon, op bepaalde publiekssegmenten of op de samenleving als totaal. In de literatuur treffen we vaak de indeling in "microlevel-" en "macrolevel"-studies aan. Stappers et al. (1983) stellen dat het onderzoek naar de invloed op de samenleving nog het minst ver gevorderd is: "... dat hoeft niemand te verwonderen, want het is ook het moeilijkst te onderzoeken".

Een bijkomende moeilijkheid bij het traceren van communicatieeffecten is het feit dat de "communicatiewetenschap" berust op een 
grote diversiteit van basisdisciplines: werd vroeger deze wetenschap voornamelijk gevoed door psychologie, sociologie en politieke wetenschappen, thans leveren de linguistiek, antropologie, opvoedkunde, economie en informatica (telematica) een forse bijdrage.

De respons op massacommunicatieve boodschappen kan op verschillende dimensies variëren. De respons kan betrekking hebben op effecten in termen van nieuwe kennis, nieuwe attitudes of nieuw gedrag. Als effect kan men ook aanmerken het bekrachtigingen en/of bevestigen van bestaande opvattingen, attitudes en gedrag en het versterken van cognities, opinies, meningen, etc.. De invloed van de media wordt als sterk aangeduid wanneer deze erin slaagt om veranderingen te bewerkstelligen in kennis, attitude en gedrag. Het meest succesrijk is een ombuiging van ongewenst naar gewenst gedrag of een verschuiving van bestaand gedrag naar gewenst gedrag. Bovengenoemde veranderingen voltrekken zich op het individuele niveau.

Natuurlijk mist de kracht van de media haar uitwerking niet op het niveau van organisaties, instituties en op de samenleving als totaal. Deze veranderingen op macro-niveau zijn vanwege de veelzijdigheid en complexiteit niet vaak object van empirische studie geweest. Toch beweren sommige auteurs (Ball Rokeach, De Fleur, 1975) dat de media effectiever zijn buiten de persoonlijke ervaringswereld van het individu om. Met name in tijden van spanning, crises en onzekerheid schijnt men middels massamediale beïnvloeding sociale systemen te kunnen beheersen. Het meest sprekende voorbeeld is de propagandamachine van Goebbels in de Tweede Wereldoorlog.

McQuail (1983) hanteert de richting van het effect als indeling van effecten op individueel niveau:

1. geplande verandering;

2. ongeplande verandering;

3. verandering in vorm en intensiteit;

4. faciliteren van verandering (gepland of ongepland);

5. bekrachtiging van bestaande bestaande opvattingen attitudes en gedrag;

6. Voorkomen van verandering.

Met het voorkomen van verandering bedoelt McQuail de gevolgen van doelbewuste ondersteuning en verspreiding van eenzijdige of ideologisch getinte boodschappen. De opsomming is niet uitputtend 
want in feite hoort hier ook nog de categorie "geen verandering" bij, maar deze kan zeer moeilijk vastgesteld worden.

\subsection{Typologie van media-effecten}

Golding (1980) heeft een typologie van media-functies opgesteld, waarbij hij op de verticale coördinaat de intentionaliteit van de zender plaatst en op de horizontale coördinaat het tijdsperspectief weergeeft.

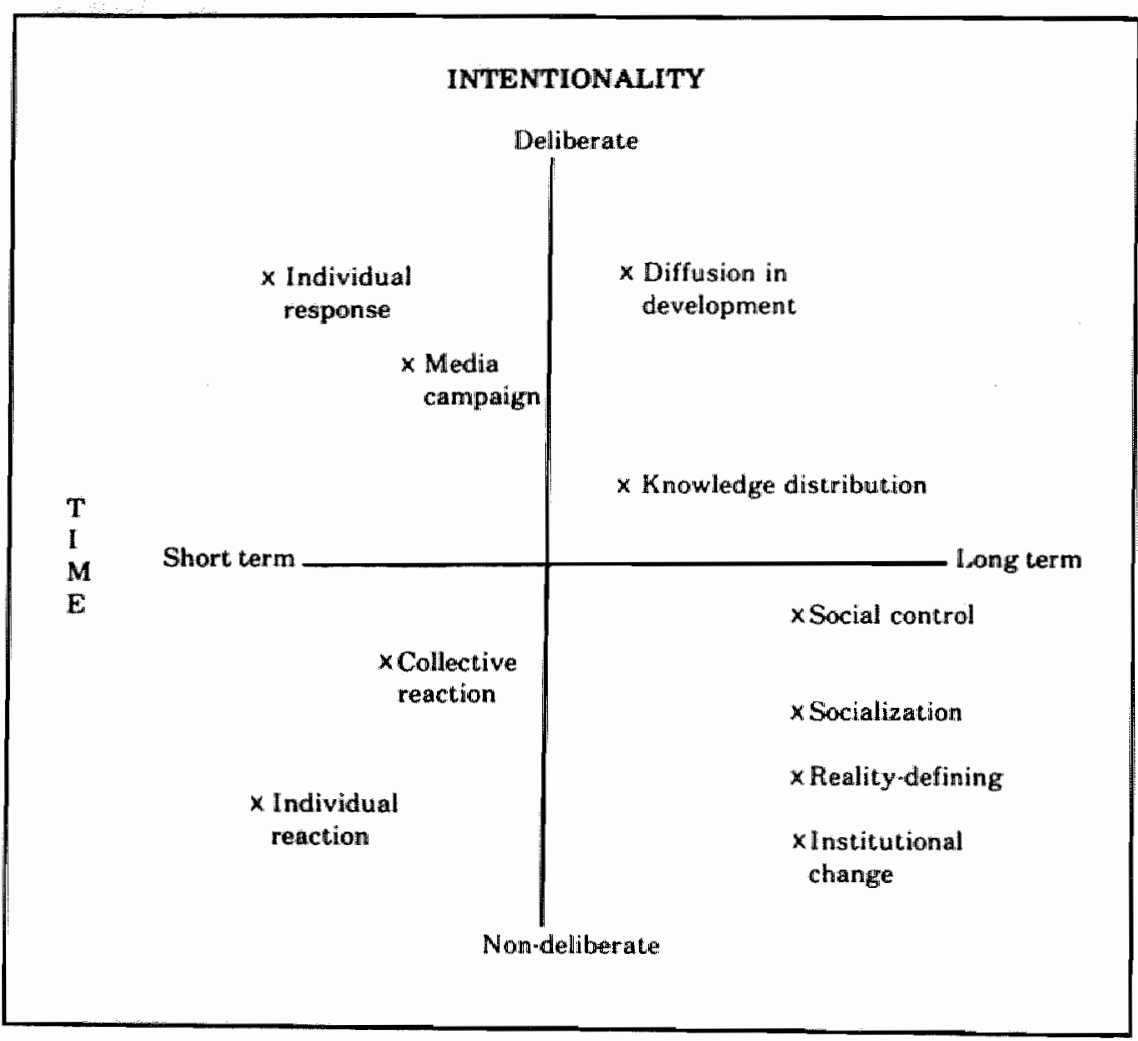

figut 7.2 Typologie van media-effecten.

Bron: McQuail, 1983, pag. 181. 
Op deze wijze worden de media-effecten als vierdeling in kaart gebracht, namelijk gewenste effecten op korte termijn, gewenste effecten op lange termijn, ongewenste effecten op korte termijn en ongewenste effecten op lange termijn. Figuur 7.2 brengt het totaal aan media-effecten in beeld.

Tot de individuele respons rekent Golding de individuele verandering (of weerstand daartegen) als respons op boodschappen, ontworpen en samengesteld met de bedoeling kennis, attitude en gedrag op korte termijn te beïnvloeden. Tot hetzelfde domein rekent hij de effecten van mediacampagnes; meerdere media worden ingezet om middels overreding bij een bepaalde populatie de beoogde doelstellingen te verwezenlijken. Ongeplande en onvoorspelbare gevolgen van blootstelling aan de media bij een persoon noemt hij individuele reactie. Deze gevolgen worden gesitueerd in het vlak van ongewenste effecten op de korte termijn. Onder deze effecten worden zoal gerubriceerd angstreacties, imitaties, sexuele prikkeling en identificaties met helden en sterren. Wanneer deze effecten tegelijkertijd optreden bij zeer veel mensen, is er sprake van een collectieve reactie, bijvoorbeeld modetrends, burgerlijke ongehoorzaamheid, hamsteren of paniekreacties. Diffusie van innovaties en effecten van campagnes die doordringen tot interpersonale netwerken, alsmede veranderingen in structuren van instituties en gemeenschappen worden ondergebracht bij de geplande effecten op de langere termijn. Ook kennis-distributie en bewustwordingsprocessen worden tot dit domein gerekend.

Socialisatie, sociale controle, institutionele verandering zijn nietgeplande effecten op de lange termijn. Media kunnen een informele bijdrage leveren aan verandering van bestaande waarden en normen; zij kunnen de legitimiteit van bestaande autoriteiten in twijfel trekken; zij kunnen het realiteitsbesef beïnvloeden en kunnen op institutioneel niveau veranderingsprocessen in gang zetten. Roberts en Maccoby (1985) maken ten aanzien van socialisatie-effecten onderscheid tussen prosociale en antisociale effecten. Tot de antisociale effecten rekenen zij bijvoorbeeld de invloed van tv-geweld op delinquent gedrag; tot de prosociale rekenen ze de effecten die een positieve uitwerking hebben op gedrag, bijvoorbeeld saamhorigheid en solidariteit. Aan beide soorten effecten liggen dezelfde ideeên ten grondslag, namelijk de principes en modellen van de sociale leertheorie (Rushton, 1982). 
Massamedia hebben in potentie de mogelijkheid om emotionele response op te roepen. We kunnen hierbij denken aan ceremoniele rituelen alls sportevenementen, parades, shows, protestdemonstraties, etc. Deze effecten zijn nagenoeg onzichtbaar en moeilijk te meten. Dit geldt in zekere mate ook voor - zoals Gerbner et al. (1980) noemen - de tendens de status quo te handhaven. Het handhaven van de status quo is wellicht het meest belangrijke gevolg van de massamedia. Noelle-Neuman (1977) stelt in dit verband dat de competentie van de media om de bestaande toestand te handhaven minstens zo belangrijk is als de competentie om veranderingen te bewerkstelligen. Sommige auteurs verwijten de media de belangenbehartiging van de status quo, terwijl anderen beweren dat ze het sociale systeem ondermijnen.

Gevaarlijk voor meningsvorming en -uiting zijn totalitaire regimes wanneer ze een monopolie-positie in de informatievoorziening hebben (Rüstow, 1980). Er zijn talrijke onderzoekers die rapporteren dat de ideeën die de massamedia uitdragen door de jaren heen overgenomen worden door grote publiekssegmenten. Zo wordt gezegd dat de huidige generatie jonge Amerikanen narcistische consumenten zijn, geobsedeerd door het verwerven van materialistische objecten (Conger, 1981; Restak, 1982). De invloedrijke, kritische stroming van de Frankfurters (Habermas, Adorno, Marcuse et al.) richtte zich met name op de ideologische effecten van de massamedia. Zij betichtten de media ervan de werkelijkheid cognitief en ideologisch te structureren conform de belangen van de sociaal-machtigen. De verbeelde werkelijkheid wordt sterk vereenvoudigd, ontdaan van alle details en wordt gedomineerd door bepaalde ideologieën vervat in vertrouwde en herkenbare beelden die de televisie aan het publiek ter beschikking stelt. Bouwman (1987) veronderstelt een discrepantie tussen "de" televisiewerkelijkeid en "de" realiteit: gebeurtenissen uit de realiteit krijgen binnen televisie een andere betekenis. De televisiewerkelijkheid wordt weliswaar aan de realiteit ontleend, maar wordt voornamelijk bepaald en verzonnen door programmamakers. Het gaat dus om een fictieve werkelijkheid, die door bewerking en selectie tijdens en na de opname in scene wordt gezet. Adorno (1976) stelt dat effecten niet worden veroorzaakt door wat direct wordt waargenomen, maar door verborgen boodschappen. Deze latente boodschappen, zijn volgens Adorno van groter belang dan de manifeste: de kijker wordt gemanipuleerd door een mengvorm van manifeste en latente boodschappen. Echter de inzichten van Adorno en zijn na- 
volgers zijn onvoldoende empirisch onderbouwd; ze zijn vanwege het hoge abstractieniveau moeilijk naar onderzoek te vertalen.

Sociaal-wetenschappellijk onderzoek naar de effecten van de massamedia veronderstelt kennis van de stimulus, controle over zijn toepassing, inschatting van het effect en overzicht/inzicht in onderliggende processen en mechanismen. Voor een beter begrip van de effecten van de massamedia op het menselijke gedrag is het volgens Roberts en Maccoby(1985) noodzakelijk zich rekenschap te geven van de volgende criteria:

1. control and/or assessment of media and/or media content;

2. control and/or assessment of exposure to the media and their content;

3. definition and assessment of the consequences of exposure;

4. assessment, elaboration, and interpretation of the conditions and processes that explain the relationship between exposure and its outcomes.

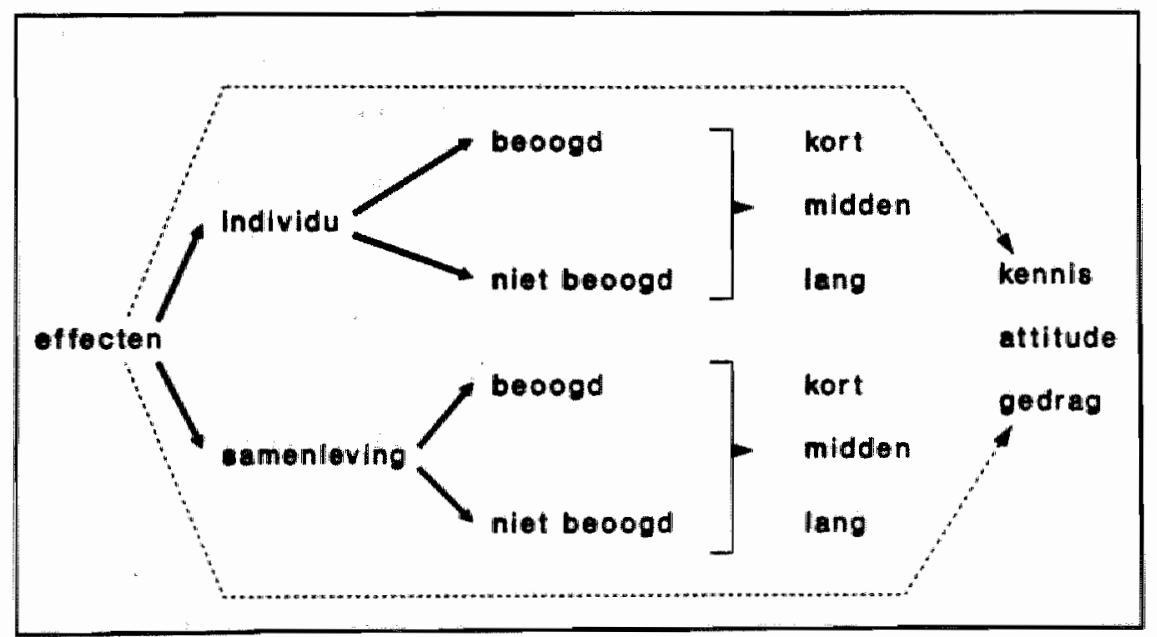

Figuur 7.3 De effecten van massamedia in grote lijnen.

Deze criteria erkennen het multidimensionele karakter van de media; zij verschaffen niet alleen inzicht in de aard van het effect (cognities, 
attitude of gedrag), maar geven ook inzicht in andere dimensies zoals de tijd of de richting van de invloed (handhaven, veranderen, bekrachtigen, stabiliseren).

Resumerend kunnen we de effecten van de massamedia in grote lijnen als in figuur 7.3 in beeld brengen.

\subsection{Directe versus indirecte effecten}

De meeste coryfeeën op het gebied van massacommunicatieonderzoek met betrekking tot gezondheidsvoorlichting (onder andere McGuire, Macoby, Solomon, Schramm, Atkin, Tones, Mendelsohn, Wallack, Flay, Cook) komen op grond van (uitgebreid) empirisch onderzoek tot de conclusie dat de effecten van de massamedia triviaal zijn, als het gaat om veranderingen in kennis, attitude en gedrag. Nagenoeg eensluidend beweren zij dat er wel effecten zijn, maar dat deze slechts marginaal zijn in omvang en continuiteit. De overgrote meerderheid van de gepubliceerde studies in vakbladen is niet in staat om effecten aan te tonen die het 0.5 van statistische significantie halen. Zelfs deze kleine effecten kunnen niet meer dan 2 of $3 \%$ van de variantie van de afhankelijke variabelen verklaren (McGuire, 1986). Voor alle duidelijkheid: bovengenoemde auteurs spreken dus niet van geen effecten, maar tonen uitsluitend aan dat de effecten niet omvangrijk zijn. Echter, ook hier moeten we de nodige voorzichtigheid betrachten, want bijvoorbeeld een massamediale poging om mensen aan te zetten om te stoppen met roken, die resulteert in een afname van $1 \%$ van de rokers, is een relatief, en zeker naar de aard van probleem, eclatant succes. McGuire (1986) wijst erop dat men bij het opsporen van geplande effecten vaak tijdelijke bij-effecten gemakkelijk over het hoofd ziet. Hij herinnert aan de "Wet van de minimale effecten" van Klapper (1960): "Mass communication ordinarily does not serve as a necessary and sufficient cause of audience effects". Indien bijvoorbeeld blijkt dat de media niet in staat zijn om het stemgedrag van kiezers te veranderen, kunnen ze er wel toe bijdragen dat men gaat stemmen. Een soortgelijk effect vonden Cacioppo en Petty (1979). In de reclamewereld gaat men ervan uit dat advertenties nauwelijks bijdragen aan het vergroten van de omzet. Indien men echter ophoudt met het plaatsen van advertenties voor een bepaald produkt, zal dit onmiddellijk merkbaar zijn aan de omzet. Men dient hier wel bij te bedenken dat dit niet opgaat voor advertenties waarin lucratieve 
dan wel attractieve aanbiedingen worden gedaan. Ook in de adoptie van innovaties vond men soortgelijke bij-effecten (Rogers, 1982). De gevonden effecten werden niet toegeschreven aan de directe invloed van de media, maar waren het gevolg van mond-tot-mond communicatie, die indirect aan de media ontleend is.

Sensationele berichtgeving over actuele, opzienbarende gebeurtenissen en de vertoning van ficties kunnen ertoe leiden dat er aanzienlijke veranderingen optreden in de verbeelding van de ontvangers (Katz; 1980). Deze effecten zijn slechts marginaal omdat ze de perceptie slechts zeer kortstondig beïnvloeden (Ball-Rokeach et al, 1981; De Bock en Van Lil, 1981).

Media sorteren weleens effecten, wanneer onderwerpen aan de orde worden gesteld die direct persoonlijk relevant zijn voor de persoon in kwestie. De ontvankelijkheid voor deze informatie is gebaseerd op het idee dat de gehanteerde argumenten precies passen in het referentiekader van de ontvanger. Hill et al. (1982) registreerden een toenemend vertrouwen in en frequentere uitvoering van borstzelfonderzoek, nadat men kort voordien geconfronteerd was met voorlichtingsmateriaal. Tyler en Cook (1984) presenteerden tegenovergestelde gegevens: mensen die vinden dat geweld op televisie leidt tot meer criminaliteit, geven te kennen dat het risico om zelf slachtoffer te worden van criminaliteit niet toeneemt. Atkin et al. (1973) merken in dit verband op dat deze bij-effecten vooral zijn terug te vinden bij mensen die al in een bepaald onderwerp geïnteresseerd zijn. Andere onderzoekers (Erbring, Goldenberg en Miller, 1980) spreken de bevinding van Atkin tegen: de mensen die het meest geïnteresseerd zijn in politiek, laten zich het minst beïnvloeden door massamediale politieke campagnes. Nauw verwant met het voorafgaande effect is het synergetisch effect; dit treedt op wanneer men informatie verwerft uit minstens twee onafhankelijke bronnen die elkaar onderling versterken. Mensen stellen zich sceptisch op ten aanzien van nieuwe informatie vanuit én bron, maar wanneer ze (nagenoeg) tegelijkertijd uit meerdere bronnen dezelfde informatie ontvangen, zwakt deze scepsis af en is men meer geneigd om de inhoud van de boodschap over te nemen. Dit synergetische effect manifesteert zich uitdrukkelijker wanneer de informatie aansluit bij directe ervaring van de betrokkenen en/of ondersteund wordt door face-to-face communicatie (Evans et al., 1981; McGuire, 1986). Voor sommige mensen heeft de televisie een modelling-effect; media moeten in sommige gevallen in staat worden geacht om bepaald gedrag te kanaliseren. Bijvoorbeeld 
mensen die van plan zijn om een misdaad te plegen worden door de TV geinspireerd om bepaalde criminele methoden over te nemen. Berkowitz en Geen (1967) zijn van mening dat tv-producties geen agressiviteit opwekken, maar mensen met slechte bedoelingen op het idee brengen de agressie in een bepaalde vorm ten uitvoer te brengen. Ook is bekend dat de media invloed kunnen hebben op het tijdstip waarop deze modelling ten uitvoer kan worden gebracht. Wanneer bepaalde mensen geraakt worden door een vertoning, zullen ze hun voornemens eerder ten uitvoer brengen. Philips (1982, 1983) toonde dit trigger-effect aan bij een zelfmoordstudie: media kunnen de timing van bepaalde voornemens op korte termijn beïnvloeden. McGuire (1986) stelt dat de media op kleine, hypergevoelige segmenten van de populatie wel degelijk hun invloed uitoefenen: potentiële criminelen, angstige mensen, hypochonders, etc.. Politieke campagnes kunnen marginaal succes boeken bij mensen die apathische zijn ten opzichte van politieke ontwikkelingen, bij mensen die slecht geinformeerd zijn of bij mensen die de keuze-beslissing tot het laatste moment uitstellen (Atkin et al., 1973). Schoolkinderen zijn erg kwetsbaar voor commerciële advertenties; zij kunnen moeilijk onderscheid aanbrengen in communicatie-inhouden (Adler et al., 1980). Uit innovatie-diffusie-onderzoek blijkt dat bepaalde elite groepen snel op berichten uit de media reageren, met name mensen met een hogere opleiding die een centrale positie in de maatschappij innemen en mensen die economisch voordeel kunnen behalen. Ook mensen met bepaalde persoonlijkheidskenmerken (angst, depressie of lage zelfachting) zijn gevoelig voor sociale invloeden (McGuire, 1985). Het meest ontvankelijk voor massamediale invloed zijn de mensen die weinig weerstand kunnen bieden tegen beïnvloedingspogingen, bijvoorbeeld jonge kinderen en mensen die in hun informatievoorziening sterk afhankelijk zijn van een bepaald massamedium, bijvoorbeeld de "zware" tv-kijker (Vierkant, 1986).

Naast directe effecten kunnen we ook nog een andere categorie effecten onderscheiden. We duiden deze aan met de term indirecte effecten: zij treden weliswaar op door toedoen van de massamedia, maar voltrekken zich via interpersonale processen en interpersonale instituties. De invloed van de media is bij deze effecten gradueel. Ze zijn niet onmiddellijk na de communicatie meetbaar als gevolg van uitgestelde actie. $\mathrm{Zij}$ treden als het ware gefilterd na verloop van tijd aan het licht. Deze effecten zijn grofweg het object van studie ge- 
weest in drie onderzoeksrichtingen, namelijk de two-step-flow-theorie, de agendasetting-theorie en de kenniskloofhypothese.

De grondgedachte van de two-step-flow-theorie is dat er een relatief kleine groep mensen sterk geinteresseerd is in nieuwe informatie en daarmee zeer ontvankelijk is voor media-inhouden. De meerderheid van de ontvangers wordt niet direct door de media aangesproken maar laat zich in haar besluitvormingsproces leiden door de mening van de geïnteresseerde minderheid, de zogenaamde opinieleiders. Lazersfeld et al. (1948) veronderstelden dat media-boodschappen via deze opinieleiders naar het brede publiek stromen: "...Ideas often flow from radio and print to the opinionleaders and from them to the less active sections of the population". Anno 1990 stat de oorspronkelijke "two-step-flow-theorie" op losse schroeven in de zin van rechtstreekse beïnvloeding van het publiek door opinieleiders. Van Cuilenburg en Noomen (1984) maken in dit verband een onderscheid tussen horizontale en verticale opinieleiders. Tot de horizontale opinieleiders rekent men personen die invloed uitoefenen op anderen met een nagenoeg gelijke positie op de maatschappelijke ladder. Verticale opinieleiders zijn personen die invloed uitoefenen op anderen die lager op de sociale ladder staan (Van Cuilenburg en Noomen, 1984, pag. 149). In de vijftiger jaren was er overigens al sprake van een "multi-stepflow". Onmiskenbaar is dat met de introductie van deze theorie het belang van interpersonale communicatie als verlengstuk van massacommunicatie benadrukt werd. Naar aanleiding van deze theorie zijn steeds meer onderzoekers waarde gaan hechten aan de rol van sociale relaties en daarmee aan informele massacommunicatie. Het is niet geheel ondenkbaar dat voor sommige populaties deze inzichten nog van toepassing zijn. Van Cuilenburg en Noomen (1984) maken een kritische kanttekening bij de rol van opinieleiders, namelijk dat zij de ontvangen informatie niet exact doorgeven, maar slechts die informatie die in overeenstemming is met eigen opvattingen, normen en waarden van de groep waartoe men behoort. Dit betekent in wezen dat de informatie gefilterd ("kwadratisch selectief") het brede publiek. bereikt. MoGuire (1986) wijst nog op een andere variant van de twostep-flow-theorie, namelijk dat bepaalde "elite"-media andere "massa"media beïnvloeden. Ook in diffusiestudies wordt de rol van persoonlijke relaties bij het overdragen, verspreiden en aanvaarden van nieuwe ideeën aan de orde gesteld. 
In dit bestek past ook de agendasetting-theorie: het idee dat de massamedia een regulerende functie wordt toebedeeld ten aanzien van de informele massacommunicatie. De media structureren in zekere mate het onderwerp van gesprek gedurende een bepaalde periode. Door de keuze van de onderwerpen, de wijze waarop ze deze aan de kaak stellen en de intensiteit, bepalen ze de mate van belangrijkheid voor het publiek (McCombs en Shaw, 1972). De media maken dus in het informele circuit (op school, thuis en op de werkplek) bepaalde onderwerpen saillant. In dit kader is het van belang vast te stellen dat agendasetting-effecten voornamelijk zijn terug te vinden in de eerste fase van het communicatieproces (aandacht en begrip). Of agenda-setting-effecten verder reiken dan de eerste fase met andere woorden of ze ook attituden en gedrag beïnvloeden is twijfelachtig. De sterkte van de agendasetting-effecten is afhankelijk van de omvang en intensiteit van de berichtgeving. Het effect fluctueert ook met de beschikbaarheid van andere informatiebronnen (Chaffee en Wilson, 1977). Of mensen de berichtgeving inderdaad als belangrijk ervaren, is weer afhankelijk van de persoonlijke relevantie van de informatie voor de ontvanger en de directe omgeving. Staatsen (1980) kraakt ten aanzien van de agendasetting een kritische noot: het is niet allemaal rozegeur en maneschijn wat de media te bieden hebben; mediaconsumptie leidt tot verarming van sociale relaties en verstoort derhalve het contact tussen mensen. Uit kijk- en luistercijfers blijkt dat verstrooiing (amusement, variete, sport, etc.) via de media bijzonder hoog op prijs gesteld wordt.

Wellicht de meest belangrijke effecten, die de media sorteren zijn vermeerdering van kennis en informatiewinst. Ontegenzeggelijk is het verwerven van informatie voor het grote publiek een belangrijk motief voor mediagebruik. Tichenor, Donohue en Olien (1970) ontdekten een correlatie tussen de sociaal-economische status van mensen en de feitelijke kennis over bepaalde thema's. De media dragen weliswaar bij aan het vermeerderen van kennis maar mensen met een hogere sociaal-economische status profiteren aanzienlijk meer van de media dan mensen uit de sociaal lagere klassen. Dientengevolge wordt de kenniskloof eerder vergroot dan verkleind. Ettema en Kline (1977) vatten de verklaringen voor deze kenniskloof als volgt samen:

"1. Ceiling effects imposed by the amount or nature of the information of concern (that operate to narrow gaps between groups); 
2. Communication deficits within one of the groups under consideration (e.g. lack of communication skills among respondents of lower socio-economic status);

3. Between-group differences in perceived relevance of, or motivation to acquire, the specific information under study (e.g. socioeconomic status locates different perceptions of the utility of a given kind of information)."

Heuvelman (1989) heeft ernstige twijfels over de kenniskloofhypothese. In zijn onderzoek bleek dat op de langere termijn juist geen verschil meer optreedt in wat mensen met verschillende opleidingsniveau's nog kunnen reproduceren (zie ook hoofdstuk 9). Hij veronderstelt dat deze hypothese wellicht alleen betrekking heeft op gedrukte media. Ook Stappers et al.(1983) plaatsen vraagtekens bij deze kenniskloof-hypothese in het geval er audiovisuele media in het geding zijn.

Dervin (1981) wijst erop dat de verantwoordelijkheid voor deze kenniskloof niet uitsluitend kan worden toegeschreven aan het publiek; de communicatoren zouden zich meer rekenschap moeten geven van de communicatieve vaardigheden van de verschillende publiekssegmenten.(zie ook hoofdstuk 4). Haar bevindingen sluiten nauw aan bij de "facto selectiviteit" van Sears en Freeman (dat will zeggen selectiviteit hangt nauw samen met opleiding). Hoger opgeleiden maken volgens Robinson (1967) intensiever gebruik van de gedrukte media. Hij probeert daarmee de kenniskloof te verklaren vanuit het mediagebruik: gedrukte media zoeken meer aansluiting bij reeds geïnteresseerden, electronische media voegen daar nauwelijks iets aan toe. Genova en Greenberg (1979) stellen dan ook dat interesse een betere voorspeller is dan de sociaal-economische status. Dit zou ervoor pleiten om meer aandacht te schenken aan het verhogen van de motivatie tot kennisverwerving en -verwerking teneinde de kloof te dichten. Deze stelling wordt door McLeod et al. (1979) empirisch ondersteund door campagne-resultaten te tonen waarin de nadruk werd gelegd op het verhogen van de betrokkenheid en participatie. 


\subsection{De effecten van massamedialle campagnes}

In het navolgende zullen we kort en bondig verslag doen van en ons nader verdiepen in campagne-effecten, m.n. met betrekking tot gezondheidswoorlichting. Hierbij is de opmerking gepast dat er methodologisch nogal wat knelpunten zijn, waardoor mogelijke vergelijkingen de toets der kritiek niet kunnen doorstaan.

Campagnes kunnen omschreven worden als opzettelijke interventies om het gedrag, attitude of kennis van het publiek te beinvloeden met behulp van massacommunicatieve boodschappen. Onder deze definitie kunnen politieke, commerciële als ook publiekscampagnes gerekend worden; het bereiken van een vooraf bepaald doel en het gebruik van massamediale middelen is een gemeenschappelijk kenmerk. Bij massamediale voorlichting is beïnvloeding een equivalent van: informeren, overtuigen en mobiliseren (Rogers en Storey, 1987). Het is zonneklaar dat er zich tussen deze vormen aanmerkelijke verschillen voordoen. Zo hebben bijvoorbeeld politieke campagnes doorgaans korte-termijndoelstellingen, terwijl publiekscampagnes met een sociaal objectdoelstelling zich over een ruimere tijd uitstrekken. Uitzonderingen bevestigen deze regel zoals bijvoorbeeld het plotselinge optreden van besmetting van het drinkwater, hetgeen aanleiding is voor onmiddellijke actie op korte termijn. Van commerciële campagnes is bekend dat ze zowel korte als lange-termijn-doelstellingen kunnen hebben; dit is sterk afhankelijk van de boodschap die men wil propageren. Er zijn veel commerciële campagnes, bijvoorbeeld in de sfeer van corporate communication, die uitdrukkelijk langere termijn doelstellingen hebben. Campagnes verschillen aanmerkelijk in de mate waarin factoren als betrokkenheid, selectieve blootstelling, gepercipieerde bias, rationaliteitsnormen, de kwaliteit van de informatie, de relevantie van andere stimuli, en de aard van de sociale structuur, hun invloed op het uiteindelijk resultaat doen gelden. Alle drie genoemde vormen maken gebruik van het informatie-procesmodel en zijn gericht op het verwezenlijken van geplande effecten.

Geplande effecten zijn de gewenste gevolgen van het blootstellen aan massamedia conform de intentie van de zender. Indien de zender bewust het oordeel van de ontvanger tracht te beïnvloeden in een door hem gewenste richting, spreken we van persuasieve communicatie. Nauw verwant met persuasieve communicatie is de imperatieve communicatie; deze is uitsluitend gericht op uiterlijk waarneembare gedragsverandering. Doorgaans gaat imperatieve com- 
municatie - all dan niet expliciet - gepaard met sanctionering in de vorm van beloning of straf. Bij persuasieve communicatie voltrekken de effecten zich op cognitief, affectief en gedragsniveau, terwijl bij imperatieve communicatie de effecten uitsluitend gericht zijn op het gedragsniveau. Zoals gezegd kunnen campagnes gebruik maken van electronische media, gedrukte media en een combinatie van beide. In de literatuur wordt de meeste aandacht besteed aan de electronische media en is met name de positie van de televisie sterk overgewaardeerd, terwijl de meeste informatie via de gedrukte media wordt overgebracht (Pool, De Sola, 1983). In het algemeen wordt aangenomen dat informatie (i.c. nieuwsvoorziening) via gedrukte media vollediger en meer waarheidsgetrouw is dan via electronische media. Becker en Whitney (1984) verklaren het verschil in potentiële invloed van deze mediavormen vanuit het verschil in vaardigheid in de omgang met deze mediavormen. $\mathrm{Zij}$ beweren dat de vaardigheden die benodigd zijn om te kunnen lezen, minstens zo geschikt zijn om ook audiovisuele boodschappen te decoderen. Een andere plausibele verklaring is dat regelmatige lezers over meer voorkennis beschikken om audiovisuele informatie makkelijker te kunnen verwerken. Het feit dat met name het medium TV veelvuldig gebruikt wordt, heeft ook te maken met het gegeven dat dit medium het hoogste bereik garandeert. Nu er steeds meer tv-netten in gebruilk worden genomen en het assortiment buitenlandse zenders is uitgebreid, is het een open vraag of de televisie deze garantie nog kan bieden. Van belang bij de mediumkeuze is niet alleen het functioneel gebruik en het communicatievermogen van het medium maar bovenal een aantal sociaalpsychologische factoren zoals mediagedrag, interesse, motivatie en groepslidmaatschap. In hoofdstuk 3 is daar uitvoerig op ingegaan.

Omvangrijke sommen geld worden besteed aan commerciële advertenties. Niet alleen worden gigantische bedragen gereserveerd voor het plaatsen van advertenties, ook met het professioneel vervaardigen ervan zijn aanzienlijke bedragen gemoeid. Bij commerciêle reclame is het niet direct de bedoeling dat mensen tot aanschaf van een bepaald product overgaan, maar meer om het merk onder de aandacht van het publiek te brengen. Indien het wel uitdrukkelijk de bedoeling van de fabrikant is om zijn omzet te verhogen of een nieuw produkt te introduceren dan is de reclame-uiting doorgaans een aspect van de marketing-communicatie. Kort samengevat komt het erop neer dat marketing gericht is op het aanwenden van een samenhangend en 
onderling afhankelijk geheel van hulpmiddelen ("tools"), te weten het product (de kwaliteit, samenstelling), de plaats van verkoop (distributie), de prijs en de promotie (reclame, een gratis vaatdoek/schotelsplak bij aanschaf van een flacon autoshampoo of de kans op een droomreis voor twee personen naar de Canarische eilanden). De beslissing tot het kopen van een product wordt bepaald door de intrinsieke (gebruikswaarde) en extrinsieke (psychologische waarde) eigenschappen van het product en de prijs die daarvoor betaald moet worden. Dat in reclamekringen de invloed van de media bejubeld wordt, vindt deels zijn rechtvaardiging in het feit dat de pretentie van het gewenste effect betrekkelijk laag is. Men streeft niet naar attitude- of gedragsverandering, maar stelt zich al tevreden als de boodschap wordt opgemerkt. De kracht van commerciële reclame moet worden toegeschreven aan het presenteren van eenzelfde boodschap, herhaald via verschillende media gedurende lange tijd. Soms gaat het om een hele lange periode. Bijvoorbeeld Coca Cola hanteerde tientallen jaren hetzelfde reclameconcept en het bier van Heineken is nog steeds " heerlijk en helder". Wallack (1981) verklaart de mogelijke invloed van reclame op attitude en gedrag vanuit het kanalisatie-principe: de media bevestigen de bestaande attitudes in een specifieke richting. O'Keefe (1974) gaf dezelfde verklaring maar voegde eraan toe dat reclameboodschappen appeleren aan een bepaalde behoefte die door aanschaf of gebruik bevredigd kan worden. Econometrische studies hebben slechts triviale effecten op het aankoopgedrag aangetoond (Albion, 1983). McGuire (1986) beschikt over aanwijzingen dat de enorme reclamebudgetten - ondanks het feit dat ondernemers scherp kunnen calculeren -in geen verhouding staan tot de mogelijke opbrengsten. Veel geld wordt ook gestoken in onderzoek naar de effecten van politieke campagnes op het stemgedrag van de kiezers. Bekend zijn de verkiezingsdebatten op de televisie bij de Amerikaanse presidentsverkiezingen; ook in Nederland hecht men kennelijk veel waarde aan televisie-uitzendingen vlak voordat de kiezer zijn/haar stem gaat uitbrengen.

Het idee dat de media een krachtige invloed op de beslissing van de kiezers uitoefenen, wordt niet ondersteund door empirische gegevens. Wel is er een positieve relatie gevonden tussen het campagne-budget (i.c. het kopen van televisiezendtijd of advertenties) en de verkiezingsuitslag maar er is geen sprake van een causale relatie (Patterson, 1982). Er zijn weliswaar minimale invloeden gevonden, bijvoorbeeld bij mensen die hun beslissing tot het laatste moment uitstellen, maar 
deze kunnen niet als verklaring dienen voor veranderingen in de omvang en richting van een verkiezingsuitslag (Page en Shapiro, 1984). In tegenstelling tot bewuste beinvloeding middels spots en politieke debatten hebben opiniepeilingen - die in wezen niet als beinvloedingspoging mogen worden aangemerkt- wel invloed op de intentie van de kiezer (Glynn en McLeod, 1982). Campagnes gericht op een persoonlijk doel of collectief doel zijn minder omvangrijk en aanmerkelijk minder van kwaliteit dan commerciële en politieke campagnes.

Anti-rookcampagnes zijn er niet in geslaagd om het aantal rokers te reduceren, maar hebben er wel toegeleid dat reclame voor rookwaren van de electronische media geweerd worden (Murphy, 1980). McGuire stelt dat evaluatiestudies met betrekking tot "sociale objecten" overwegend negatieve resultaten laten zien. In het algemeen zijn ze methodologisch erg zwak, bijvoorbeeld het ontbreken van een controlegroep of ondeugdelijke nulmetingen. Doorgaans meet men uitsluitend de mate van blootstelling en komt men niet toe aan het registreren van harde indicatoren, die inzicht verschaffen in de mate waarin de doelstellingen gerealiseerd zijn. De methodologisch betere evaluatiestudies laten over het algemeen trieste resultaten zien. Robertson (1976) vond na een 9 maanden durende interventie ter bevordering van het dragen van autogordels geen verschil tussen de experimentele en de controlegroep. Schanie en Sundel (1978) schonken evenveel aandacht aan de ontwikkeling van materialen als aan het onderzoeksontwerp met betrekking tot een interventie naar het bevorderen van de toegankelijkheid van de geestelijke gezondheidszorgbureau's. Er werden geen noemenswaardige effecten gesorteerd, noch op het gebruikmaken van deze faciliteit, noch op de kennis van het bestaan van deze instelling. In de campagne van Schmeling en Wotring (1980) tegen het gebruik van drugs werd de boodschap vele malen herhaald. Het succes bleef echter uit: geen afname van het gebruik en zelfs geen toename van kennis. Peterson (1984) rapporteerde zelfs geen effecten op attitude en gedrag wanneer de boodschap via de electronische media gevolgd werd door schriftelijk voorlichtingsmateriaal. Geen compliance-effecten werden gevonden in degelijke studies van Tyler (1984) met betrekking tot het nemen van voorzorgsmaatregelen tegen kleine criminaliteit. De studie van Peterson (1984) over vermageren en het onderzoek van Udry (1974) naar gebruik van anti-conceptiva lieten zien dat de campagnes bedroevende resultaten boekten. Het televisie-gezondheidsprogramma 
"Feeling Good" rapporteerde significante effecten bij een relatief beperkt publiek Het programma verdween spoedig van de buis, omdat er maar door zeer weinigen naar gekeken werd (Mielke en Swinehart, 1976). De evaluatie van een ander tv-programma "VD Blues" liet naast een verhoogde kennis over geslachtsziekte ook een substantiële toename zien van bezoeken aan klinieken direct na de uitzending (Greenberg en Gantz, 1976).

Naarmate campagnes van meer media gebruikmaken en ondersteuning en/of aansluiting bij interpersonale voorlichting zoeken, neemt de effectiviteit toe. In het navolgende zullen we enige multimediale campagnes bespreken. Voor de goede orde: de term multimediaal is niet voorbehouden aan campagnes die meer dan én massamedium aanwenden, maar heeft ook betrekking op campagnes waar massamedia en interpersonale voorlichting in combinatie worden gebruikt.

De meest bekende multimediale campagne is de "Three Cities"campagne gericht op het reduceren van cardiovasculaire ricsicofactoren. Onderzoekers van de Stanford University Communcation Reseach Institute (Farquhar et al, 1977; Macoby en Alexander, 1980; Maccoby en Solomon, 1981) onderwierpen drie gemeenschappen aan verschillende condities. Een stad diende als controle-groep en ontving de normale informatie, de tweede stad werd blootgesteld aan electronische en gedrukte media en een derde stad ontving naast informatie via electronische en gedrukte media, ook interpersonale communicatie. $\mathrm{Na}$ twee jaren werden significante verschillen gevonden met betrekking tot cognitieve-, affectieve- en gedragsvariabelen. De campagne was het meest succesrijk waar zowel massamediale als individuele voorlichting plaats had gevonden: het gemiddelde cholestorolgehalte van de interventiesteden was lager dan in de controlestad. Opmerkelijk is nog het gegeven dat (alleen) massamedia een verandering teweeg konden brengen in eetgewoonten (Farquhar et al., 1983). Bemoedigende resultaten met multimediale campagnes werden ook bereikt in het Finse North Karelia project (Puska et al, 1979; Puska, McAlister, Pekkola en Koskela, 1981). Ook hier werd de massamediale campagne vergezeld van interpersonale voorlichting. $\mathrm{Na} 10$ jaar kon worden vastgesteld dat het sterftecijfer in de interventiegroep met $22 \%$ was gedaald, terwijl dat in de controlegroep $12 \%$ bedroeg. Het succes van dit project kan worden toegeschreven aan een aantal factoren: er werd veel aandacht geschonken aan het mobiliseren van de bevolking om deel te nemen aan informatiebijeenkomsten, hetgeen ertoe heeft geleid dat de bevolking actief is gaan participeren in het 
project; de voorlichting werd geïntegreerd in de bestaande gezondheidszorgvoorzieningen; de doelen van de verschillende interventies werden nauw op elkaar afgestemd en zo mogelijk in combinatie uitgevoerd; de overheid had een stimulerende rol inzake financiering, beleid en het creëren van voorzieningen; de planning en uittvoering van het project verliep met behulp van wetenschappelijk onderzoek, i.c. terugrapportage over de stand van zaken en bereikte successen en de gemeenschapszin in een homogene gemeenschap werd vergroot. Vandaag de dag zou een dergelijk project met de titel "Health Promotion" worden aangeduid (zie De Leeuw, 1989).

\subsection{Nederlandse voorlichtingscampagnes}

De Nederlandse Hartstichting heeft bij het formuleren van de doelstellingen voor een grootschalige gezondheidscampagne, genaamd de "Way of Life-campagne" (1988), gebruik gemaakt van de bevindingen van de hier bovengenoemde projecten. Het doel van de actie was om de aandacht van het publiek te vestigen op het belang van een gezonde leefstijl bij de preventie van hart- en vaatziekten. Als afgeleide hiervan probeerde men begrip te kweken en kennis over te dragen over vier leefstijlcomponenten, te weten voeding, roken, beweging en stress. De campagne maakte niet alleen gebruik van de massamedia, maar werd ook ondersteund door een actie-karavaan, die door het land trok en door het verspreiden van actiemateriaal. De voorlichters kozen voor een luchtige aanpak, afwisselend informatie en amusement en een positieve benaderingswijze, het benadrukken van wat wel mag en plezierig is in plaats van aangeven wat niet mag. Betrekkelijk uniek voor de Nederlandse situatie is dat men deze campagne vergezeld heeft doen gaan van een viertal deelonderzoeken, namelijk een effectmeting ten aanzien van kennis, attitude en gedragsintentie, een onderzoek naar de waardering van huisartsen, een appreciatie-onderzoek bij een kleine groep mensen die de campagne op de voet gevolgd heeft en een onderzoek onder het publiek naar reacties op de campagne en vragen naar aanleiding hiervan. Rescon (1989) rapporteert dat de campagne geslaagd genoemd mag worden: de campagne is positief ontvangen, de doelgroepen zijn in grote mate bereikt, de huisartsen weten waardering op te brengen voor de campagne en de televisieprogramma's zijn goed bekeken. Kortom het aandacht-trekken voor een gezonde leefstijl is gelukt. De 
campagne liet ook effecten zien op gedragsintentie en gedragsniveau. Bijvoorbeeld van degenen die het afgelopen half jaar aangeven gestopt te zijn met roken, zegt ongeveer $10 \%$ dat te hebben gedaan naar aanleiding van de Way of Life-campagne. Ook is men minder gaan drinken. Rescon schrijft deze veranderingen toe aan de campagne omdat er geen sprake is van tijds- of interview-effecten. Ondanks de verheugende effecten, geraken wij niet in jubelstemming. Een paar kritische kanttekeningen zijn hier op zijn plaats, allereerst betreft het korte-termijn-effecten, die spoedig kunnen wegebben als er geen follow-up volgt. Bovendien zijn beweringen van gedrag gemeten en geen feitelijk gedrag. Ons gematigd optimisme komt voort wit een onderzoek van Marsman en Peeters (1978), die ook bemoedigende resultaten lieten zien (die op theoretische gronden niet te verwachten waren) naar aanleiding van een NCRV-programma over "stoppen met roken". De bereikte positieve resultaten van de "Way of Life-campagne" zullen alleen maar te handhaven zijn als de activiteiten via sociale netwerken gecontinueerd worden. Anno 1990 zijn nauwelijks initiatieven merkbaar die als follow-up van de "Way of Life-campagne" kunnen worden aangemerkt. We zijn dan ook geneigd om deze incidentele actie als weinig vruchtbaar te beschouwen.

De meest bekende campagnes in Nederland hebben betrekking op het beteugelen van het drankmisbruik in het verkeer. Kayser (1990) stelt dat er geen empirisch bewijs voorhanden is dat aantoont dat massamediale voorlichtingscampagnes over rijden onder invloed effect sorteren op gedrag. Evaluatie-studies uit binnen- en buitenland (Rooyers, 1986; Buisman, 1987) tonen duidelijk aan dat van massamediale campagnes alleen resultaat verwacht mag worden als zij in combinatie met andere preventieve maatregelen plaatsvinden. We denken hierbij bijvoorbeeld aan een verhoogde pakkans, "alcohol ignition interlocks", meer politiecontrole, nachtbussen en discovervoer. Dat voorlichting nauwelijks vat krijgt op de alcoholproblematiek, heeft onder andere te maken met het ontbreken van een deugdelijke strategie, die op basis van grondig onderzoek wordt uitgestippeld en waarbij concrete, realistische doelstellingen worden geformuleerd. Zo is het de schrijver dezes nog steeds niet duidelijk of er wel, soms, matig, verstandig, een beetje veel of helemaal niet gedronken mag worden als je nog wilt rijden. Communicatieboodschappen dienen consistent te zijn; ook wanneer de interventie zich over een langere periode uitstrekt. Er kunnen verschillende redenen zijn om de vorm van de boodschap te veranderen maar de inhoud dient consequent 
overeind te blijven. Het telkenmale veranderen van de inhoud van de boodschap schept verwarring en draagt op geen enkele wijze bij aan cognitieve ordening die als eerste voorwaarde moet worden gezien voor effectiviteit. Dat massamedia op het gebied van de alcoholpreventie niet veel kunnen uitrichten, heeft - naast het gegeven dat alcohol sociaal geaccepteerd is in alle lagen van de bevolking - te maken met de complexiteit en weerbarstigheid van de problematiek: voor zowel stevige drinkers als incidentele gebruikers is minder of niet drinken geen reëel handelingsalternatief, omdat er geen gratificatie aan verbonden is. Inherent aan alcoholgebruik is het feit dat men de ernst (het veroorzaken van ongelukken) en de kwetsbaarheid (de hoeveelheid alcohol gerelateerd aan de rijvaardigheid) onderschat. Daarom zou men meer de nadruk moeten leggen op het handelingsalternatief "vervoer". Het bevestigen en bekrachtigen van activiteiten verdient de voorkeur boven het steeds opnieuw veranderen van de voorlichtingsboodschap.

Vanaf 1976 zijn talloze voorlichtingscampagnes georganiseerd om het roken terug te dringen. De resultaten zijn, wat gedrag betreft, betrekkelijk mager, met één uitzondering, namelijk dat er een sterke antirookbeweging is ontstaan, die te vuur en te zwaard het roken wil bestrijden. Evaluaties van Nederlandse publiekscampagnes bekommeren zich uitsluitend om de eerste fasen van het voorlichtingsproces, namelijk om de vraag of de boodschap is aangekomen en welke waardering men er voor heeft. Onderzoek naar de effecten op het rookgedrag zelf ontbreken of zijn moeilijk serieus te nemen omdat er nogal wat methodologische bezwaren aan kleven. Van der Rijt en Baan (1984) beschouwen, naar aanleiding van de campagne "Wie rookt is niet gezien", massacommunicatie als gangmaker voor interpersoonlijke communicatie. De genoemde campagne was succesrijk in die zin dat ze de discussie over rookoverlast in de werksfeer, heeft aangewakkerd. Het succes van deze campagne, dat wil zeggen de positieve waardering, discussie en activiteiten om rookoverlast in te perken, kan worden toegeschreven aan drie factoren: a. de campagne sloot nauw aan bij de actuele problemen in de werksituatie; b. een genuanceerde benadering die niet polariseerde tussen rokers en nietrokers; c. het ondergeschikt maken van massacommunicatie aan interpersonale voorlichting. Massamedia werden in de onderhavige campagne ingezet om een bewustwordingsproces over de problematiek (roken in de werksfeer) in gang te zetten. Vervolgens werden gevraagd en ongevraagd voorlichtingsmaterialen toegezonden om de 
discussie in de interpersonale sfeer aan te wakkeren. Het is bemoedigend dat deze campagne er in geslaagd is om indirect via massamedia groepsdiscussies op gang te brengen. Helaas ontbreekt ook bij deze campagne een deugdelijke onderzoeksopzet (in het evaluatieonderzoek ontbraken de benodigde voor- en nametingen) en laat de campagne geen resultaten zien op het feitelijke rookgedrag. De onderzoekers rapporteren het opmerkelijke feit dat in 1983 het aantal rokers weer met $3 \%$ gestegen is en stellen : "Het is de vraag in hoeverre dit te wijten is aan het feit dat er na beëindiging van de campagne in mei 1981 geen nationale actie meer gevoerd is " (pag. 17). De laatste jaren heeft men bij de rookpreventie een duidelijke scheiding aangebracht tussen acties die gericht zijn op het voorkómen dat men gaat roken (Evans, 1976; Best et al., 1988), en programma's die mensen willen helpen om definitief van het roken af te komen (Mudde, 1989).

Voorlichtingscampagnes met betrekking tot energiebesparing hebben als doel mensen meer bewust te maken teneinde energiebesparend gedrag te bevorderen. Uit een grootscheepse energiebesparingscampagne (SVEN, 1978) blijkt dat de kennis over energiebesparing weliswaar is toegenomen, doch niet de houding ten aanzien van energiebesparing. De campagne heeft eerder de bestaande attitude versterkt en slaagde er niet in om consumenten aan te zetten tot intensievere energiebesparing. Midden et al. (1982) noemen als verklaring de volgende factoren: a. gedragsverandering met betrekking tot energiebesparing impliceert een inperking van vrijheid en comfort; $b$. er wordt teveel nadruk gelegd op negatieve gedragsaspecten, zoals minder warm stoken, minder verlichten, etc., in plaats van dat er meer nadruk wordt gelegd op het gerief van een geisoleerd huis; c. de campagne was onvoldoende gesegmenteerd naar doelgroepen, waardoor men geen aansluiting kon vinden bij de vigerende waarden, normen, verwachtingen en behoeften; $d$. de rol van de overheid was twijfelachtig, namelijk geen stimulans in de vorm van het stellen van voorbeelden, geen maatregelen, die erop zouden kunnen duiden dat het inderdaad om een serieus probleem gaat, geen krachtige argumentatie om energieschaarste geloofwaardig te maken. Midden (1982) somt een aantal andere factoren op dat debet is aan het falen van deze campagne. Men had veel problemen kunnen voorkomen, als men zich vór de interventie verdiept had in de problematiek Dan was zonder twijfel aan het licht gekomen dat bijvoorbeeld sociale normen invloed uitoefenen op het gedrag (bijvoorbeeld dat besparing 
als gierig en krenterig overkomt). Ook had men dan rekening kunnen houden met rationalisaties in de zin van het goedpraten van eigen gedrag. Bovendien ontbrak het aan eenduidige informatie over de effectiviteit van de te nemen maatregelen.

Van Raaij en Verhallen (1980) concluderen naar aanleiding van een soortgelijk onderzoek in Vlaardingen, dat de attitude ten aanzien van energiebesparing weining gerelateerd is aan gedrag (maximaal $5 \%$ van de verschillen). Volgens de onderzoekers voelen consumenten zich niet verantwoordelijk voor het ontstaan van energietekorten en denken dat hun eigen bijdrage aan de oplossing van dit probleem slechts een druppel op een gloeiende plaat is. Kok et al. (1979) verklaarden daarentegen $20 \%$ van de gedragsverschillen uit de verschillen in attitude. Hierbij moet worden aangetekend dat de onderzoekers geen feitelijke gedragsmetingen hebben gedaan, maar zich beperkten tot beweringen over gedrag. Halsema en Rogmans (1979) rapporteerden ook sombere gegevens van een massamediale campagne met betrekking tot kinderveiligheid. De campagne was alleen effectief in het onder de aandacht brengen van de problematiek. Optimistische geluiden kunnen we noteren over de vuurwerkcampagne van de Stichting Consument en Veiligheid. Geconstateerd werd een substantiele daling van het aantal zware letsels door vuurwerk: in 1982 1600 ernstige verwondingen, in 1986 gedaald tot 280 . Het is de vraag of deze cijfers uitsluitend toe te schrijven zijn aan de intensieve waarschuwingscampagnes voor onverantwoord gedrag. In dezelfde periode zijn namelijk strengere veiligheidseisen gesteld, beter vuurwerk gefabriceerd en het aantal verkooppunten aan banden gelegd. Wellicht is het succes van de campagne ("Verknal je toekomst niet") toe te schrijven aan de originele benadering (agressief, hard en confronterend), het intensief gebruiken van verschillende ondersteunende media in een korte tijdspanne en het feit dat de voorlichting wordt gelanceerd op een tijdstip dat de (jonge) doelgroep zeer ontvankelijk is voor de informatie.

Buisman (1987) heeft de massamediale voorlichtingscampagnes met betrekking tot drugs in verschillende West-Europeese landen geinventariseerd. Hij concludeert dat in nagenoeg alle gevallen de meest krachtige functie van de massamedia wordt uitgebaat namelijk bekrachtiging van de reeds bestaande attitude i.c. de negatieve houding over het gebruik van drugs. De beschreven campagnes laten minimale effecten zien in termen van kennisvermeerdering over risico's en gevaren van drugsgebruik. Als positief (neven)effect geldt een toe- 
name van fondswervende activiteiten ten behoeve van de preventie van drugsgebruik. Een negatief effect is het feit dat met name jonge, onervaren mensen worden uitgenodigd om met drugs te experimenteren. Buisman sluit zich in zijn conclusies aan bij Alcala (1983) in die zin dat massamedia het best kunnen worden aangewend om lokale en regionale activiteiten te ondersteunen: "The use of community organization and the maximization of interpersonal communication are ways in which social communication campaigns can increase their effectiveness in a significant manner".

Sinds 1967 heeft de Stichting Ideële Reclame (SIRE) zo'n vijftig campagnes laten uitvoeren over ideële onderwerpen. De campagnes verstrekken informatie over een ideëel onderwerp, vragen meer begrip of hebben een waarschuwende functie. Sommige SIRE-campagnes bloeden na enkele maanden al dood, terwijl anderen jaren later nog opduiken. De bulk van deze campagnes is niet geëvalueerd; de waardering voor de campagnes wordt afgeleid uit het aantal reacties (200 a 300 per jaar) dat bij de stichting binnenkomt. Bij tijd en wijle wordt een SIRE-campagne geëvalueerd op waardering en bereik. Naar aanleiding van de SIRE-campagne "Wat ledereen over drugs moet weten" merkt Van Berkum (1985) op, dat aanvragers van nadere informatie vooral die mensen zijn, die al belangstelling voor c.q. een zekere mate van betrokkenheid met dit thema hadden. $\mathrm{Zij}$ concludeerde dat berichten via de massamedia voornamelijk dat publiek bereikten dat al belangstelling had voor dit specifieke onderwerp. De campagne was hiermee haar doel enigszins voorbij geschoten, omdat relatief weinig leden van de doelgroep (de sociale omgeving van beginnende - druggebruikers) waarvoor de informatie bestemd was, bereikt zijn.

Schaps et al. (1981) waarschuwen ervoor dat respondenten die informatie hebben aangevraagd, de neiging vertonen, om redenen van sociale wenselijkheid of uit enthousiasme voor de voorlichting, de subjectief ervaren veranderingen mooier voor te stellen dan ze in werkelijkheid zijn. Betrouwbare resultaten zijn dan ook alleen af te leiden wanneer er een voor- en nameting heeft plaatsgevonden.

Willenborg en Schmidt (1989) deden een evaluatie-onderzoek naar het voorlichtingsproces en de effecten van een Postbus 51-campagne. Het hoofddoel van de campagne was de aankoop van nieuwe auto's met een katalysator, bij consumenten te stimuleren. Met een brede frontaanval (paginadominerende dagbladadvertenties, billboards in (middel)grote steden, tv-spots, publieksbrochures) dacht men dit karwei in 
zes weken te klaren. De effecten van de campagne werden gemeten met een panelsteekproef op drie tijdstippen. In het licht van het voorafgaande zal het duidelijk zijn dat het gedragseffect bijzonder gering was. De onderzoekers concludeerden dan ook dat een gedragsdoel voor Postbus 51 en vergelijkbare campagnes geen reëel doel is. Spots zijn alleen geschikt om mensen in positieve zin gevoelig te maken voor een bepaald onderwerp. Eijken en Van Oosterzee (1990) stellen dat de Postbus 51-spots een positief imago hebben bij het overgrote deel van de kijkers. De spot: "Inbraakpreventie woning" werd in 198842 maal uitgezonden en bereikte daarmee $78 \%$ van de Nederlandse bevolking van 13 jaar en ouder. De bedoeling van spots op gedragsniveau is om de kijker een folder te laten halen. Gemiddeld is het totale bereik van de Postbus 51-folder zo'n $12 \%$ van de Nederlandse bevolking van 18 jaar en ouder (RVD/Intomart, 1987). Voorlichters zijn geneigd om aan het afhalen van folders de betekenis toe te kennen dat er een positieve houding met betrekking tot het onderwerp bestaat. Sommigen wagen het zelfs om hier het succes van een campagne aan af te meten. Willenborg en Schmidt (1989) stellen dat wanneer bewustwording wordt beoogd, het halen en lezen van de brochure een onbelangrijke functie heeft en wellicht ook achterwege kan blijven. Desondanks rapporteren de onderzoekers een groot bereik in een beperkte tijd. De campagne en met name het lezen van de brochure heeft ertoe geleid, dat bij lezers duidelijk aantoonbare veranderingen in de gewenste richting hebben plaatsgevonden. Maar, zo vervolgen de onderzoekers, de Postbus 51-campagne is geen effectief beleidsinstrument om millieuvriendelijk gedrag te bevorderen. Ook hier stoten we weer op het eerder beschreven verschijnsel dat het eigenbelang veel sterker blijkt dan het collectief of maatschappelijk belang. De grootte van de veranderingen en de aard van de veranderingen zijn te gering om voorlichting via een grootschalig instrument als een Postbus 51-campagne te rechtvaardigen. Dit geldt niet alleen voor kortdurende campagnes op nationaal niveau. Ook op regionaal niveau is een kortdurende publiekscampagne weinig zinvol. Zo stelden wij vast dat een regionale publiekscampagne gericht op automobilisten met als doel ouderen rustig en met respect in het verkeer te bejegenen, nauwelijks werd opgemerkt (Jansen et al. 1990). Deze kleinschalige campagne maakte gebruik van "free publicity" in huis-aan-huis-bladen, folders en affiches. Kennelijk is de penetratie van de TV en de advertenties in kranten toch onontbeerlijk om de boodschap onder de aandacht van het publiek te brengen. 
Volgens NSS Marktonderzoek (1987) verneemt bijna 60\% van de Nederlanders iets over preventie via de TV, daarna volgen kranten en tijdschriften met $40 \%$. Brochures, folders en pamfletten kunnen nuttiger aangewend worden als hulpmiddel in persoonlijke voorlichting.

Van Riel (1979) bestudeerde een zevental campagnes, waaronder twee typische overheidscampagnes, namelijk " De Verstedelijkingsnota " (1976) en "Planologische Kern Beslissingen" (1977). De resultaten van deze campagnes bestrijken nagenoeg alle gradaties van succesvolheid met dien verstande dat gedeeltelijk en matig succes duidelijk de overhand hebben. Van Riel signaleert enkele opmerkelijke zaken, die anno 1990 nog niet veel aan actualiteit hebben ingeboet. De onderzoekdesigns in deze studies zijn erg zwak: soms geen nulmeting, geen controlegroep (bij massamediale voorlichting is dit inderdaad een teer punt) en doorgaans slechts eén nameting. Voorts heeft Van Riel geen enkele pretest bij deze campagnes kunnen registreren. Ook constateert hij dat de doelstellingen van de campagnes niet uitgedrukt zijn in evalueerbare termen, zodat men welhaast niet aan de indruk kan ontkomen dat de eindresultaten fraaier worden voorgesteld dan ze in werkelijkheid zijn. Ilustratief in dit verband zijn de conclusies van Eijken en Van Oosterzee (1990) ten aanzien van effecten van voorlichting bij misdaadpreventie in de jaren 1985-1988. Zij concluderen: "Voorlichting, verzorgd door de politie en door de VMstructuur, levert een reële bijdrage aan het oplossen van problemen op het terrein van de criminaliteit bij de individuele (potentiële) slachtoffers. Deze bijdrage vindt plaats op het niveau van:

- kennis (men vergroot zijn kennis omtrent preventiemogelijkheden);

- bewustwording (meer mensen worden zich bewust van het criminaliteitsprobleem en hun mogelijke rol bij de oplossing daarvan);

- gedragsverandering (meer mensen gaan het gewenste gedrag vertonen);

- gedragsbevestiging (mensen merken en zien dat het "nieuwe" gedrag inderdaad voordelen biedt en zullen dan ook bereid zijn dat gedrag te continueren)."

Eijken en Van Oosterzee (1990) temperen deze optimistische bevindingen door eraan toe te voegen dat over de omvang en continuitteit van de opgetreden veranderingen "niets" te zeggen is, omdat er in de meeste gevallen slechts een meting achteraf heeft plaatsgevonden. 
Wellicht is het een idee om de conclusies eens af te zetten tegen de criminaliteitsstatistieken.

Sinds een aantal jaren is in Nederland een fors offensief ingezet om de verspreiding van de ziekte aids tegen te gaan. Diverse campagnes en activiteiten - met zeer uiteenlopende doelstellingen en doelgroepen - zijn uitgevoerd om aids te voorkomen. Er wordt veel energie, mankracht en middelen geinvesteerd in het ontwikkelen van voorlichtingsinhouden en methoden (Reelick en De Haes, 1988).

Aidsvoorlichting in Nederland wordt gekenmerkt door een schier eindeloze reeks van voorlichtingsactiviteiten: programma's op scholen, lokale en regionale voorlichtingsbijeenkomsten, folders, affiches, activiteiten van belangenverenigingen etc. De dreiging, in de zin van ernst en kwetsbaarheid, van deze ziekte rechtvaardigt overigens een grootscheepse aanpak. Gexien de brede waaier van activiteiten - men zou welhaast kunnen spreken over "een ondoorgrondelijk wespennest" (hetgeen overigens niet alluderend bedoeld is) - is het moeilijk, zo niet onmogelijk, om de invloed van de massamediale campagnes te traceren. Buisman (1987) beschouwt de Aidscampagne als een succesverhaal: uit gegevens van Intomartenquetes concludeert hij dat massamediale campagnes zelden zo succesrijk zijn geweest. Niet iedereen deelt deze mening. Zo meldt Van Triest (1988) dat "Voorlichting geen enkel nuttig effect op gedrag heeft" en Hesterman (1988) constateert dat randgroepjongeren immuun blijken te zijn voor antiaidscampagnes. Luijkx et al. (1987) rapporteren zwakke, korte termijneffecten naar aanleiding van de SIRE-campagne over sexueel overdraagbare aandoeningen maar voegen er nadrukkelijk aan toe dat deze resultaten vertekend kunnen zijn, doordat ze interfereren met andere acties.

Reelick en De Haes (1988) stellen dat er weinig of geen onderzoeksgegevens zijn over aidsvoorlichting; zij gaan er echter op basis van keinschalig effectenonderzoek van uit dat aidsvoorlichting gunstige resultaten laat zien ten aanzien van het voorkomen van paniekreacties. Mede als gevolg daarvan kon een sterke daling van het aantal geslachtsziektes worden vastgesteld, maar het is vooralsnog niet duidelijk of er ook minder aidsgevallen zullen optreden. Samenvattend kan men stellen dat over de effectiviteit van voorbehoedmiddelenvoorlichting het laatste woord nog niet gezegd is. 


\subsection{Slotbeschouwing}

De meningen over het al dan niet effectief zijn van de massamedia lopen sterk uiteen. Ook in wetenschappelijke kring bestaat er geen consensus. We zijn van mening dat zonder een duidelijke doelspecificatie het onmogelijk is om vast te stellen welke betrouwbare maatstaven moeten worden aangelegd om effectiviteit te meten. In het algemeen kan men stellen dat, wanneer men het over effectiviteit van de massamedia heeft, gedoeld wordt op de beoogde effecten, dat wil zeggen resultaten conform de intentie van de zender. Een discussie over de effectiviteit van de massamedia is zinloos als we niet aangeven welke effecten worden nagestreefd. Zijdelings hebben we erop gewezen dat het niet juist is om over "de" massamedia te spreken; we kunnen de diverse media niet over een kam scheren, omdat ieder medium zijn eigen kenmerken, functie, draagkracht, reikwijdte en communicatievermogen heeft. Belangrijk is om het tijdsperspectief in de discussie te betrekken, waardoor mogelijkerwijze een genuanceerder beeld over de werking van massamedia ontstaat.

De bespreking van massamediale campagnes is niet uitputtend; we hebben ons beperkt tot die studies die in de literatuur als belangrijk worden aangemerkt of waaraan vaak gerefereerd wordt. Wij wijken in onze conclusies geenszins af van de algemene tendens die in de aangehaalde literatuur naar voren komt, namelijk dat het gebruik van uitsluitend massamedia in interventies een zwak middel is om veranderingen in houding en gedrag te bewerkstelligen. Indien professioneel aangewend, blijken de diverse massamedia wel in staat om veranderingen in het cognitieve domein aan te brengen, namelijk kennisvermeerdering en bewustwording. De massamedia zijn in het algemeen wel geschikt om bestaande opvattingen, attituden en gedrag te bevestigen en te versterken. Voor de voorlichtingsstrategie impliceert dit, dat massamedia in het begin en op het einde van het voorlichtingsproces een betekenisvolle functie kunnen vervullen.

Een sight-seeing van Nederlandse campagnes laat nagenoeg hetzelfde sombere beeld zien als de "bekende" buitenlandse campagnes. Het is opmerkelijk dat doorgaans een florissantere weergave van resultaten wordt gerapporteerd zonder dat er daadwerkelijk indicatoren zijn die op significante veranderingen wijzen. In het slothoofdstuk zullen we pogen om enkele vuistregels te formuleren die een bijdrage aan de effectiviteit kunnen leveren. 


\title{
Hoofdstuk 8 Preventie van skiblessures; een gerandomiseerde interventiestudie
}

\author{
8.1 Inleiding \\ 8.2 Doelstelling van de interventiestudie \\ 8.3 Probleemanalyse en gedragsdeterminantenanalyse \\ 8.4 Concretisering van het interventie-doel \\ 8.5 De compositie en het pretesten van de boodschap \\ 8.6 Methode van onderzoek \\ 8.7 Resultaten \\ 8.8 Effecten van voorlichting \\ 8.9 Discussie en conclusies
}

\subsection{Inleiding}

Algemeen wordt aangenomen dat actieve sportbeoefening een positief effect heeft op gezondheid. Er zijn echter geen exacte gegevens bekend over de gezondheidswaarde van sport (WVC, 1986). Auteurs die zich negatief uitlaten over sporten zijn in de minderheid. Ofschoon het nodig blijft om de ontwikkelingen op sportgebied kritisch te volgen (en te waken voor uitwassen), rekent men verantwoord gedoseerde en goed begeleide sportbeoefening tot de gezonde bezigheden.

Sportbeoefening in de vorm van lichamelijke inspanning ontwikkelt de spierkracht en verbetert het uithoudingsvermogen en het evenwichtsgevoel. Bovendien versterkt fysieke inspanning het skelet en verhindert het de ontwikkeling van vetweefsel. Andere geopperde 
voordelen zijn een grotere wreerstand tegen ziekten en een verbetering van de reactiesnelheid, waardoor men minder kans loopt op ongelukken (Van Rens, 1982). Ook spelen psychosociale factoren een rol, zoals geestelijke ontspanning, contacten met andere mensen en het realiseren van geldingsdrang (Van Rens, 1982; Stromme et al., 1982).

Uit preventief oogpunt wordt het gebrek aan regelmatige lichaamsbeweging aangemerkt als een risico voor het krijgen van diverse aandoeningen, zoals bijvoorbeeld hart- en vaatziekten. Het behoeft weinig betoog dat de aard en de tak van sport medebepalend zijn voor de te verwachten gezondheidswinst.

Sporten heeft ook duidelijk zijn schaduwzijden: sportblessures vormen een zware aanslag op de financiën van het volksgezondheidsbeleid in het bijzonder en op de kosten van de nationale economie in het algemeen.

Een legitimering voor de ontwikkeling van het overheidsbeleid inzake blessure-preventie moet dan ook gezocht worden in de uit de hand gelopen kosten, die met genezing en verzorging van sportblessures gepaard gaan.

In de afgelopen jaren zijn tal van activiteiten ontplooid met als doel mensen te stimuleren om actief sport te beoefenen. Tegenwoordig komt ook de aandacht voor medische begeleiding en blessure-preventie steeds meer voor het voetlicht. In de Nota 2000 (1985) wordt gewag gemaakt van het streven om het aantal sportongevallen in het jaar 2000 met 25 procent te reduceren. De Nota Veiligheid in de Privésfeer (1984) geeft aan dat het minimaliseren van sportongevallen bereikt kan worden door het aanpassen van reglementen en gedragsregels, door de bevordering van de veiligheid van materialen en door voorlichting.

In het recente verleden zijn tal van voorlichtingscampagnes op touw gezet om de aandacht van het publiek te vestigen op het belang van sporten voor de gezondheid en om blessures ten gevolge van het sporten te voorkomen.

Over de effecten van deze - doorgaans massamediale - campagnes tasten we in het duister: er zijn geen cijfers bekend die erop wijzen dat deze campagnes aan hun verwachtingen hebben beantwoord. De resultaten van deze campagnes zijn niet in vaktijdschriften gepubliceerd. Het ontbreken van evaluatie-gegevens zet kracht bij aan de twijfel dat deze activiteiten niet op een systematische, doelgerichte en planmatige methodiek gegrondvest zijn. 
In dit hoofdstuk doen we een poging om de bevindingen, die we in hoofdstuk 1 tot en met 7 hebben geventileerd, te integreren. Het voorbeeld van een onderzoek mag zich er echter niet op laten voorstaan een ideaaltypische omschrijving van een massamediale interventie te zijn. Dit heeft onder andere te maken met de aangegane verplichtingen met de opdrachtgever, het feit dat het schrijven van de theorie en het onderzoek niet in tijd hebben gespoord, en het gegeven dat de experimentele opzet van het onderzoek ons parten speelde in de opzet en implementatie van deze interventie. Toch hebben we in grote lijnen vast kunnen houden aan onze eerder geformuleerde beginselen. Zo staan we uitvoerig stil bij de probleem- en gedragsdeterminantenanalyse, er is secuur gezocht naar een adequate boodschap en er is terdege rekening gehouden met de context waarin de de ontvanger de boodschap moet verwerven en verwerken. Ook de keuze voor de experimentele condities vloeit voort uit de voorafgaande theoretische bespiegelingen maar is toch hoofdzakelijk ontleend aan het feit dat er in de literatuur ten aanzien van deze facetten een grote lacune bestaat.

\subsection{De doelstelling van de interventiestudie}

De Stichting Consument en Veiligheid is een van de instanties in Nederland die zich actief bezighoudt met sportblessurepreventie. Over het algemeen hanteren zij een sporttakgerichte benadering en maken zij gebruik van massamediale middelen. Een van de sporten waar de Stichting haar aandacht op richt, is het skiën. Besloten werd om, alvorens met een grootscheepse campagne over het voorkomen van skiblessures te starten, eerst een wetenschappelijk onderzoek te verrichten.

In onderstaand schema wordt aangegeven welke wegen bewandeld zijn om van probleem tot communicatiedoel te geraken:

Het interventiedoel geeft aan naar welke effecten bij een bepaalde populatie gestreefd dient te worden en omschrijt de te verwachten resultaten in termen van verifièerbare indicatoren. Het communicatiedoel heeft betrekking op de inhoud van de boodschap, waarin wordt aangegeven welke handelingen (gedrag) van de mensen verwacht worden. Het spreekt voor zich dat een interventiedoel meer communicatiedoelen kan bevatten. 


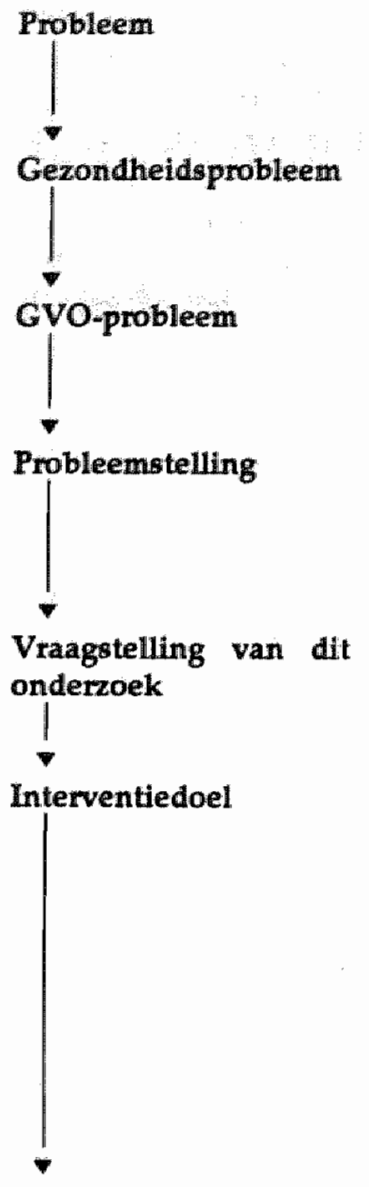

Communicatiedoel
Het behandelen en verzorgen van skiblessures heeft nadelige gevolgen voor de samenleving

Het beoefenen van de skisport heeft nadelige gevolgen voor thet welzijn van de individuele sporter

Het gedrag van de sporter heeft een positieve dan well negatieve invloed op het voorkomen van blessures

Kan het gedrag van de skiềr door middel van voorlichting beinvloed worden, zodat een reductie van het aantal blessures bewerkstelligd wordt?

Op welke wijze kan een gezondheidseducatieve interventie bijdragen aan het voorkomen van skiblessures?

Voorlichting moet leiden tot:

-toename van kennis over de te nemen veiligheidsmaatregelen ten aanzien van de ski-uitrusting

-bewustwording van de gevaren en een positieve houding ten aanzien van veiligheid

- acceptatie van de velligheidsadviezen

- positieve intentie ten aanzien van het gebruik van de ski-uitrusting

Het laten afstellen van de skibindingen door de vakman met behulp van een testapparaat

Figuur 8.1 Van probleem tot communicatiedoel. 
De algemene vraagstelling van het onderzoek is als volgt geformuleerd: "Op welke wijze kan een gezondheidseducatieve interventie bijdragen aan het voorkomen van skiblessures?" Deze algemene vraagstelling laat zich concretiseren in de volgende deelvragen:

1. Probleemanalyse:

- Wat is de incidentie van skiblessures?

- Wat zijn de etiologische factoren van skitraumata?

- In hoeverre speelt het gedrag van mensen een rol bij het oplopen van een skiblessure?

2. Gedragsdeterminantenanalyse:

- Welke determinanten bepalen het vertoonde gedrag en welke determinanten zijn van invloed op het gewenste gedrag?

- In welke mate verhouden zich de gedragsdeterminanten tot het gezondheidsprobleem (de relatieve belangrijkheid)?

- In hoeverre kan Gezondheidsvoorlichting en -opvoeding functioneel en effectief worden aangewend, om de determinanten in de gewenste richting te beinvloeden (de relatieve veranderbaarheid)?

3. Wat is de meest effectieve voorlichtingsvorm bij variatie van:

a. het medium;

b. het tijdstip van benadering;

c. de benaderingswijze.

De vraagstellingen betreffende de probleemanalyse en de gedragsdeterminantenanalyse worden geëxpliciteerd middels literatuuronderzoek (zie paragraaf 8.3). De vraagstellingen genoemd onder 3, worden beantwoord door middel van een gerandomiseerde interventiestudie (zie paragraaf 8.4).

\subsection{Probleemanalyse en gedragsdeterminantenanalyse}

De probleemanalyse omvat de schatting van de omvang van het probleem, alsmede de bestudering van de relatie tussen het gezondheidsprobleem, in dit geval het optreden van skiblessures, en het gedrag van de betrokkenen.

Aan de hand van recente binnen- en buitenlandse literatuur wordt een beeld geschetst van de aard en de omvang van het gezondheidsprobleem. Tevens wordt ingegaan op de omstandigheden waaronder 
de ongevallen plaatsvinden en op de vermoedelijke oorzaken.

De gedragsdeterminantenanalyse komt slechts in beperkte mate aan bod, daar hier slechts een onderzoek naar gedaan is. Met het oog op een gefundeerd advies ten aanzien van de meeste effectieve en efficiénte vorm van voorlichting zal in dit onderzoek getracht worden te verklaren welke determinanten van invloed zijn op het uiteindelijke resultaat.

Het begrip "sportblessure" wordt in de literatuur op verschillende manieren gedefinieerd. In deze studie is gekozen voor de ruime omschrijving van de Council of Europe (1986):

"A sports injury is that which occurs as a result of participation in sport and has one or more of the following consequences:

- a reduction in the amount or level of sports activity

- a need for advice or treatment

- adverse social or economic effects".

Een consequentie van deze definitie is dat bij de interpretatie van dit begrip meer accent ligt op de subjectieve beleving van de sporter dan op objectief registreerbare feiten door derden.

Ook de term "skiletsel" of "skiblessure" wordt in de literatuur niet eenduidig gedefiniëerd. Meestal worden alleen die letsels bedoeld die gemeld zijn bij de piste-bewakingsdienst, eerste hulppost, polikliniek of ziekenhuis in of in de nabije omgeving van de wintersportplaats. De letsels die niet of niet direct medische hulp behoeven, worden meestal buiten beschouwing gelaten (Bouter en Knipschild, 1985). In dit onderzoek wordt een bredere omschrijving gehanteerd, namelijk alle letsels, zowel licht als ernstig, die tijdens het beoefenen van de skisport worden opgelopen.

Incidentiecijfers geven een duidelijk inzicht in de omvang van bepaalde problematiek, maar alleen wanneer er een sluitend registratiesysteem bestaat (Kranenborg, 1983). Gezien de ruime interpretatiemogelijkheden van het begrip skiletsel, is het moeilijk in de ongevalsstatistieken na te gaan wat precies de omvang van de incidentie is en hoe de blessures worden geregistreerd. Verschillende auteurs (Garrick en Kurland, 1971; Shealy, 1974) schatten de onderrapportage van skiletsels op $40-50 \%$ van de feitelijke registratie. Door verschillen in de gehanteerde definitie en door het gebruik van verschillende registratiemethoden zijn de incidentiecijfers uit de literatuur niet zo goed onderling vergelijkbaar. 


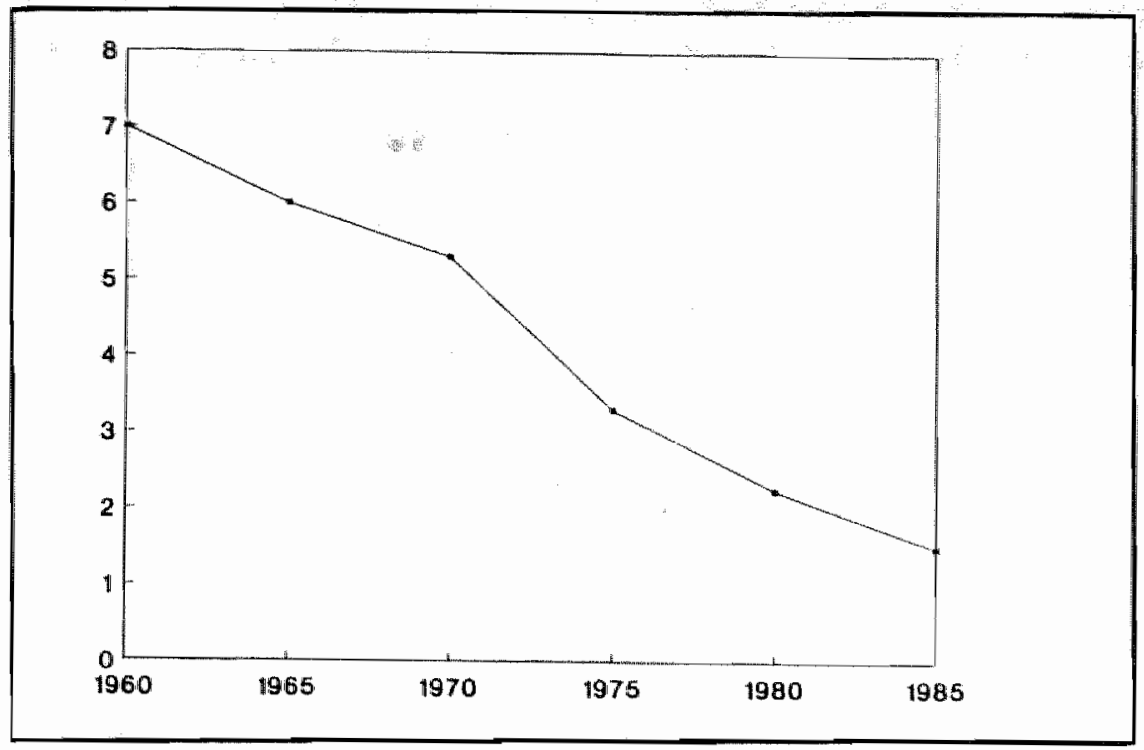

Figuur 8.2 Aantal skiblessures per 1000 skidagen, 1960-1985.

Bron: Hauser en Gläser, 1987, pag. 191.

De schattingen op basis van recente ongevalsstatistieken liggen tussen 1 en 10 blessures per 1000 skidagen (Bouter en Knipschild, 1985; Jaffin, 1981; Johnson et al., 1980). De incidentie van ernstige blessures, die een medische behandeling behoeven ligt tussen de 2 en 4 per 1000 skidagen (Hauser en Gläser, 1987; Shealy, 1985; Young, 1985).

De incidentie van skiletsels is de laatste jaren drastisch afgenomen, met name in de jaren ' 70 was er een forse afname. Thans lijkt er sprake van een gestabiliseerde situatie. Figuur 8.2 geeft een beeld van de incidentie van skiletsels over 1960 tot 1985 . Het betreft hier gemiddelden uit relevante ongevalsstatistieken uit buitenlandse literatuur.

De daling van het aantal skiletsels is voornamelijk te danken aan de verbetering van het skimateriaal, met name de skibindingen (Johnson et al., 1980; Hauser en Gläser, 1987; Kuriyama en Fujimaki, 1987).

Deze stelling wordt gesteund door de veranderingen in de localisatie van het letsel. De analyse door Hauser en Gläser (1987) van relevante buitenlandse ongevalsstatistieken geeft deze trend van veranderingen van letsels voor de verschillende lichaamsdelen duidelijk weer (zie 
figuur 8.3). Het betreft hier steeds percentages van het totale aantal blijvende letsels. Tussen 1960 en 1980 was er een duidelijke afname van $80 \%$ naar $55 \%$ voor de letsels aan de onderste extremiteiten, in het bijzonder aan de voet en de enkel (een daling van $45 \%$ tot $10 \%$ ). In dezelfde periode nam het percentage tibia-fracturen af van $25 \%$ tot $15 \%$, terwijl het percentage knieblessures gelijk bleef, rond $20 \%$. In tegenstelling tot de relatieve afname van letsels aan de onderste extremiteiten, blijken de letsels aan de bovenste extremiteiten te zijn gestegen van $10 \%$ tot $25 \%$ tussen 1960 en 1980 , terwijl het percentage letsels aan de romp en het hoofd verdubbelde tot $20 \%$.

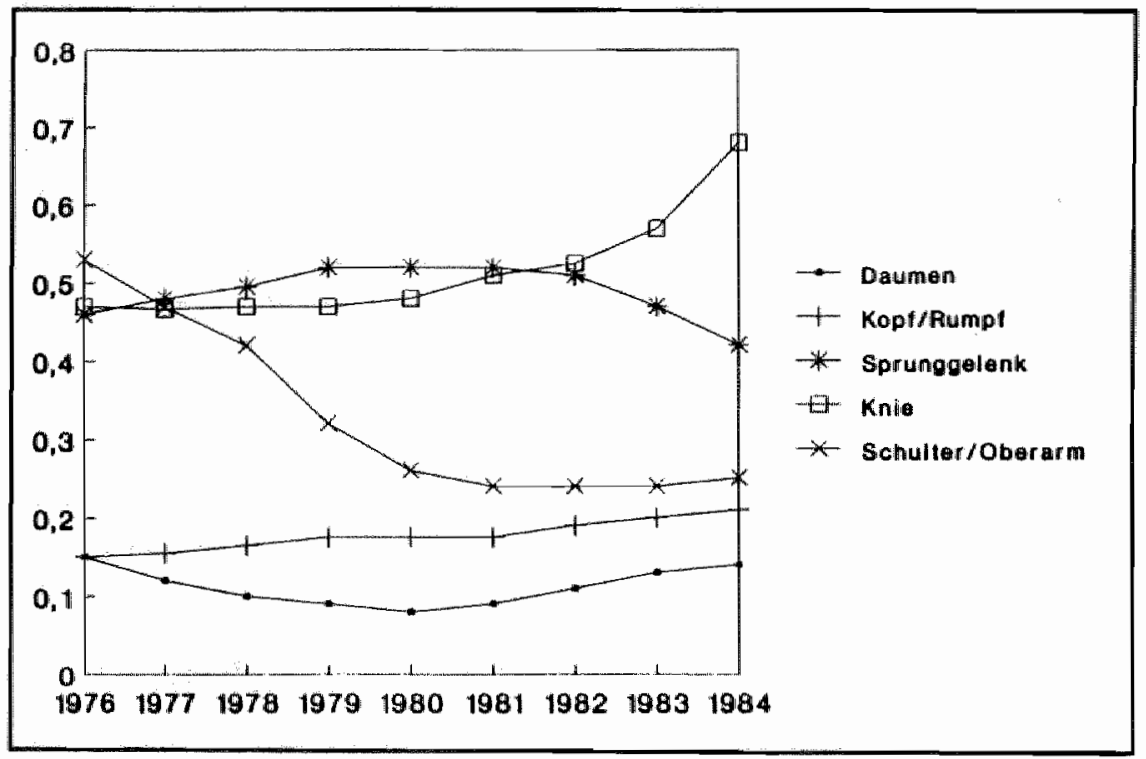

Figuur 8.3 Invaliditeit ten gevolge van ski-ongevallen per 10.000 skiërs naar localisatie van het letsel, 1976-1984.

Bron: Hauser en Gläser, 1987, pag. 196.

De etiologische factoren van skitraumata kunnen grofweg ingedeeld worden in extrinsieke en intrinsieke oorzaken. Onder extrinsieke oorzaken worden verstaan factoren buiten de skièr om, zoals klimatologische factoren (bijvoorbeeld temperatuur, zicht, conditie van de 
sneeuwlaag), situationele factoren (bijvoorbeeld veiligheid op en rond de piste, veiligheidsmaatregelen, toegankelijkheid van liften) en de mede-skiërs (aantal, technische vaardigheid, etc.). De intrinsieke oorzaken van skitraumaca hebben betrekking op de skièr zelf (bijvoorbeeld leeftijd, vaardigheid en risico-perceptie). Het zal weinig betoog behoeven dat de indeling in extrinsieke en intrinsieke oorzaken betrekkelijk marginaal is. In sommige gevallen zijn extrinsieke en intrinsieke oorzaken nauw aan elkaar gerelateerd. De afname van het aantal letsels gedurende het laatste decennium moet voornamelijk worden toegeschreven aan een verhoogde aandacht voor de extrinsieke factoren. Dit heeft ertoe geleid dat met name letsels aan de onderste extremiteiten gedaald zijn. De bellangrijkste reden voor de afname van het aantal ongelukken is de verbetering van de uitrusting, voornamelijk de drie-eenheid ski-binding-schoen. De uitrusting zelf, i.c. de technische constructie, wordt tot de extrinsieke factoren gerekend. Het gebruik van het materiaal (onderhoud, omgang, afstellen) wordt beschouwd als een intrinsieke factor, omdat de skiër zelf kan bepalen hoe hij met zijn uitrusting omgaat.

Van de geregistreerde ongevallen vindt $95 \%$ op de bewaakte pistes plaats, waarvan $60-75 \%$ op de "weicher piste" (gemakkelijk tot middelzwaar) (Bernett en Schöffel, 1982). De meeste letsels treden op ten gevolge van een val. Voor een val kunnen verschillende oorzaken zijn. Botsing met een object of met een andere skër bijvoorbeeld (3$7 \%$ ), oneffenheden in de ondergrond zoals rotsen, gras, ijs e.d. (2040\%) (Bernett en Schöffel, 1982; Meier, 1985; Tapper, 1978; Young en Loo, 1978). Relatief gezien is het aantal ongevallen op en rond de piste hoger naarmate het weer beter is. Men veronderstelt dat goed weer uitdaagt om meer risico's te nemen (Bouter en Knipschild, 1985). De alpine ski-sport wordt merendeels door jonge mensen bedreven. De gemiddelde leeftijd van mensen die een ongeval krijgen schommelt rond de 33 jaar (De Witte en Meyers, 1986). Ungerholm en Gustavsson (1985) rapporteren weinig ongevallen in de leeftijdscategorie boven 45 jaar.

De ongevalsfrequentie van kinderen is betrekkelijk hoog. Dat is ook niet zo verwonderlijk omdat de verhouding op de piste tussen volwassenen en kinderen 1 op 4 bedraagt. Bouter en Knipschild (1985) suggereren dat 11-13 jarigen een relatief hoog risico hebben. De veronderstelling is dat men zich in de vroege puberteit roekelozer zou gedragen.

Sommige auteurs (Garrick et al., 1979; Jaffin, 1981; Tapper, 1978) 
rapporteren dat vrouwen meer risico's lopen dan mannen. Anderen daarentegen zeggen dat de risico's nagenoeg gelijk zijn (Dowling, 1982; Sheally et al., 1974; Young, 1976).

De vaardigheid van skiërs kan op verschillende manieren worden geoperationaliseerd. In de literatuur wordt een duriedeling gehanteerd om skiers in te delen: de beginner (L), de middelmatige (A) en de gevorderde skiër (S). In de meeste onderzoeken wordt aan de skiêrs zelf gevraagd om aan te geven hoe hun vaardigheid is. Het is echter een bekend gegeven dat men de eigen vaardigheid nogal eens schromelijk overschat. Een andere methode om skiërs in te delen is gebaseerd op het aantal seizoenen dat men geskied heeft. Vrijwel alle auteurs zijn het erover eens dat een toenemende skivaardigheid het ongevalsrisico vermindert. Skiërs die voor het eerst op ski's staan, blijken een verhoogd risico te hebben (Shealy et al., 1974; Young, 1976). Technische onbekwaamheid is een belangrijke oorzaak van ongelukken. Beginnelingen nemen 50 a $70 \%$ van de ongevallen voor hun rekening (Biener en Fasler, 1978). Bouter en Knipschild (1985) wijzen erop dat beginners die geen skiles nemen het risico op letsel met een factor van 2 a 3 verhogen, ten opzichte van beginners die wel skiles nemen.

Biener et al. (1981) spreekt het vermoeden uit dat $20 \%$ van alle blessures samenhangt met vermoeidheid. Eriksson (1978) had dit al eerder geopperd.

Young (1976) komt op grond van schattingen tot de conclusie dat vermoeidheid een belangrijke oorzaak is van ski-ongevallen. Mogelijk is dit de reden waarom de meeste ongevallen optreden nadat men langer dan drie uur geskied heeft (Bernett en Schöffel, 1982) of in de late namiddag (Veihelmann et al., 1972).

Vaak wordt aangenomen dat de lichamelijke conditie van de skiër van groot belang is om ongelukken te voorkomen: van ski-gymnastiek, oefenen op de kunst-skibaan en regelmatige sportbeoefening zou derhalve een preventieve werking uitgaan. Bouter en Knipschild (1985) kunnen geen verschillen aangeven wat betreft een verminderd ongevalsrisico in vergelijking met mensen die dit niet doen. Uit een Canadees onderzoek van Quellet en Prince (1986) blijkt dat vrouwen beduidend vaker skiles nemen dan mannen. Deze onderzoekers vonden nauwelijks verschillen tussen mannen en vrouwen ten aanzien van de lichamelijke voorbereiding. Wel constateerden zij dat mannen hun bindingen regelmatiger laten controleren dan vrouwen. De Witte en Meyers (1986) twijfelen niet aan de effecten van een 
goede lichamelijke conditie, terwijl Bouter en Knipschild (1985) vonden dat mensen die zich lichamelijk op de wintersport hebben voorbereid, geen lager ongevalsrisico hebben.

Quellet en Prince (1986) onderzochten in hoeverre skiërs zich bewust waren van de risico's die met skiền gepaard gaan. Ongeveer $50 \%$ beschouwt skiën als gevaarlijk. Een grote meerderheid $(91 \%)$ van degenen die skiën als gevaarlijk beschouwt, schrijft ongelukken toe aan foutief gedrag of attitude van de andere skiërs. Het percentage skiërs, dat te kennen geeft bewust gevaarlijk gedrag te mijden is ongeveer $70 \%$. Ongeveer $13 \%$ zegt van zichzelf gevaarlijk te skièn en geeft zich geen rekenschap van veiligheidsmaatregelen. Hoe jonger de skiër, hoe gevaarlijker het gedrag dat men ten toon zegt te spreiden. De respondenten van bovengenoemd onderzoek zijn van mening dat preventieve maatregelen gericht moeten zijn op het gedrag $(64 \%)$, fysieke en technische voorbereiding (23\%), uitrusting (10\%) en externe factoren $(5 \%)$.

De skier kan tijdens zijn afdalingen een aantal risico's nemen waaraan hij niet alleen zichzelf, maar ook zijn mede-skièrs blootstelt. Deze risico's komen voort uit bijvoorbeeld zelfoverschatting, onachtzaamheid, onbezonnen uitgelatenheid, overdreven alcoholgebruik en te hoge snelheden (de zogenaamde Schussfahrt) (De Witte en Meyers, 1986). In een aantal studies stelt $O h(1981,1982)$ vast dat skièn met hoge, onbeheerste snelheden de directe oorzaak is van ongevallen die met ernstig hoofdletsel gepaard gaan.

Een opmerkelijke uitkomst van de studie van Bouter en Knipschild (1985) is dat skiërs die verklaarden voor de vakantie een beetje of erg bang te zijn geweest voor een ongeval, meer dan $40 \%$ minder risico liepen.

Het leeuwedeel van de afname van de incidentiecijfers van skiletsels gedurende de afgelopen 15-20 jaar, is te danken aan de technologische vooruitgang van de functionele eenheid ski-bindingschoen. Desondanks is het verkeerd en onzorgvuldig gebruik van bindingen nog steeds debet aan naar schatting 40 a $50 \%$ van de ongevallen (Eriksson en Johnson, 1980, Tapper, 1978; Young, 1976). Uit een onderzoek van Hauser en Gläser (1987) bleek dat $50 \%$ van de bindingen niet goed waren afgesteld. Het gevolg van een onjuiste afstelling is dat de bindingen niet of pas te laat opengaan bij een val. Naast een onjuiste afstelling worden constructie, onderhoud en bevroren bindingen als oorzaak genoemd (Eriksson, 1979). Bouter en Knipschild (1985) concludeerden uit de bestaande literatuur dat in 50- 
$80 \%$ van de gevallen de bindingen te hoog zijn afgesteld. Onderzoek van Johnson (1980) bevestigt deze bevinding. Uit een recent experimenteel onderzoek van Hauser en Gläser (1985) bleek dat personen uit de onderzoeksgroep (bij wie de bindingen door deskundigen waren afgesteld) een significant lager ongevalsrisico hadden dan personen uit de controlegroep. Ook bleek dat skièrs die hun bindingen zelf hadden afgesteld, een duidelijk hoger ongevalsrisico hadden dan de overige skiërs. Ettinger en Johnson (1982) wijzen er eveneens op dat het belangrijk is om de bindingen door vakmensen af te laten stellen. Nagel en Mösch (1987) voegen hieraan toe dat het bij het afstellen van de bindingen noodzakelijk is dat er gebruik wordt gemaakt van testapparatuur. Dat is de enige manier om een verkeerde afstelling op te sporen en te corrigeren en om functionele storingen in de bindingen te ontdekken.

Zoals beschreven in de vorige paragraaf worden in de literatuur vele oorzaken genoemd voor het ontstaan van skiletsels, waarvan er een aantal tegenstrijdig zijn. Bouter en Knipschild (1985) spreken dan ook liever van risico-indicatoren dan van oorzaken. Hoewel het aantal letsels mede dankzij de verbetering van de bindingen is afgenomen, komen letsels aan de onderste extremiteiten nog steeds vaak voor, en is een onjuiste afstelling van de bindingen de meest voorkomende oorzaak hiervan (Rosen, 1982; Hauser en Gläser, 1987)

Het gegeven dat het afstelgedrag een sterke relatie heeft met het optreden van blessures, werd door Johnson reeds in 1976 gesignaleerd. De evaluatie van een Zweedse interventie, waarbij skiërs in de gelegenheid werden gesteld de bindingen correct te laten afstellen op de piste, bracht aan het licht dat juist afgestelde bindingen de kans op het op tijd loslaten van de veiligheidsbinding met $50 \%$ verhoogt. Dit resulteerde in een afname van letsels aan de onderste ledematen met meer dan 10\%. Nadien hebben diverse auteurs (Hauser, 1987; Jonsson, 1983; Bouter en Knipschild, 1987) deze bevinding bevestigd.

Opmerkelijk is dat het juist afstellen van de bindingen nauwelijks tot object van interventie is geponeerd. Deze merkwaardige gang van zaken heeft het besluit tot gevolg gehad om in recente literatuur na te gaan welke preventieve activiteiten men heeft aanbevolen om de intrinsieke oorzaken van skiblessures te minimaliseren. Rond 1978 verschijnen er publicaties, die gewag maken van intrinsieke factoren als oorzaak van blessures: 
- beginnelingen moeten technisch beter voorbereid worden en moeten zich meer bekwamen in de techniek van het skiën (Biener en Fasler; 1978);

- mensen van 40 jaar en ouder moeten hun gedrag aanpassen aan de veranderde fysiologische condities (Wettman, 1978);

- het opstellen van gedragsregels voor skiërs en het stimuleren van warming-up (Biener en Fasler, 1978);

- verplichten tot het dragen van een valhelm voor jongeren tot 18 jaar (Oh, 1982; Oh en Smid, 1982);

- kinderen en vrouwen moeten kwalitatief hoogwaardige materialen aanschaffen (Hauser, 1985);

- betere informatieverschaffing door leveranciers van de uitrusting (Ungerholm en Gustavson, 1985);

- valhelmen bij kinderen, anatomische handgrepen van de skistokken (De Witte en Meijers, 1986);

- specifieke skigymnastiek en training op kunstbanen (Hutson, 1986);

- betere fysieke voorbereiding op de wintersport (De Witte en Meijers, 1986);

- beginners moeten skilessen nemen van vakbekwame leraren met daarbij meer aandacht voor veiligheidsaspecten (Bouter en Knipschild, 1985).

Deze brede waaier van goed bedoelde adviezen heeft er niet toe geleid dat het aantal blessures aanmerkelijk is geminimaliseerd. De opsomming van adviezen - zoals hierboven aangegeven - is niet uitputtend en slechts bedoeld als illustratie om aan te tonen dat te pas en te onpas adviezen worden geproclameerd die niet tot het gewenste resultaat leiden. De voorlichting wordt dubieus, als niet duidelijk is welke gedragsdeterminanten het probleem veroorzaken, als men niet weet of/en op welke wijze de determinant(en) beinvloedbaar zijn en er geen zekerheid bestaat ten aanzien van de effectiviteit van het advies of instructie. De kans dat voorlichting positieve effecten sorteert, wordt mede bepaald door het gegeven dat de inhoud van de boodschap ook daadwerkelijk leidt tot het gewenste resultaat. Bijvoorbeeld als men stelt dat het slikken van fluoridetabletjes caries vermindert, dan moeten die tabletjes ook bijdragen aan de reductie van het aantal gaatjes. Zodra aan de inhoud van de boodschap getwijfeld wordt door de ontvanger, mag men niet verwachten dat het gewenste gedrag wordt opgevolgd. 
Uit de probleemanalyse kan men concluderen dat de relatie tussen gedrag en het optreden van letsels zich manifesteert ten aanzien van de vaardigheid, vermoeidheid, het dragen van beschermingsmiddelen (ski-helm), het toepassen van veiligheidsmaatregelen op en rond de piste en het adequaat afstellen van de bindingen. De reden om als communicatiedoel van de interventie te kiezen voor het goed afstellen van de bindingen, berust mede op de twijfel dat andere intrinsieke factoren het cognitieve domein overschrijden en daardoor minder voor informatie-overdracht geschikt zijn.

De determinanten die ten grondslag liggen aan het al dan niet afstellen van de skibindingen zijn slechts in eén onderzoek het onderwerp van studie geweest, namelijk in het onderzoek van Rosen et al. (1982). Het probleem is niet zozeer het afstellen van de bindingen (dat wordt door een meerderheid gedaan), maar vooral het gebrek aan kennis over het juist afstellen. De enige manier om bindingen goed af te stellen is door vakmensen met behulp van testapparatuur. Skiërs kunnen er zelf zorg voor dragen dat dit gebeurt. Het laten afstellen van de skibindingen is derhalve een vorm van preventief gedrag, daar het al dan niet goed laten afstellen een sterke relatie heeft met de kans op letsel.

Voor een goed begrip van deze materie schenken we even aandacht aan het afstellen van de bindingen. Bij het afstellen van de bindingen dient men waarden toe te kennen aan de volgende grenzen:

1. de benedengrens, welke minimale actieve (spierkracht) en passieve (sneeuwweerstand) krachten toelaat die nodig zijn om de ski's te sturen;

2. de bovengrens, die de maximale krachten toelaat die nog geen trauma's ter hoogte van het onderbeen veroorzaken.

Een zekere en veilige instelling van de bindingen is te verkrijgen door een waarde te kiezen die tussen beide grenzen in ligt. De variabelen die deze waarde bepalen zijn: de transversale diameter van de tibia juist boven de fibulakop of het lichaamsgewicht, leeftijd, geslacht, skivaardigheid en de lengte van de schoenzool (Delouche, 1984; Reilly en Lees, 1984). De essentie van adequaat afgestelde bindingen is dat bij een val de binding opengaat, zodat de schoen loskomt van de ski. Het niet op tijd opengaan van de binding kan ook het gevolg zijn van slecht onderhoud, onzorgvuldigheid of van bevroren skibindingen. Het gros van de ongelukken is echter te wijten aan het feit dat de bindingen niet exact op de persoon worden afgesteld (Bouter, 1988, 
Caldwell, 1984, Hauser en Gläser, 1987, Jonsson, 1983).

\subsection{Concretisering van het interventie-doel}

In de gedragsdeterminantenanalyse werd geconstateerd dat het afstellen van de bindingen in aanmerking komt als object van interventie. Deze constatering is gewettigd op grond van het feit dat de gewenste verandering voldoet aan de criteria van relatieve belangrijkheid ( $\mathrm{er}$ is een directe relatie tussen probleem en gedrag) en relatieve veranderbaarheid (het betreft voomamelijk een cognitief probleem, dat middels voorlichting tot een oplossing gebracht kan worden).

Alvorens tot een afweging van middelen en methoden van de (mogelijke) interventie te komen, is het noodzakelijk om de doelstellingen van de interventie te concipiëren.

In aanmerking genomen dat deze interventie een aantal bouwstenen moet opleveren voor een toekomstige campagne, draagt deze studie dan ook een exploratief karakter. Onafhankelijk van de aard van de interventie wordt het realiseren van de volgende doelstellingen mogelijk geacht:

1. vermeerdering van kennis over:

a. de werking van de binding;

b. het nut van persoonlijke afstelling;

c. de voorzorgsmaatregelen ten aanzien van de uitrusting;

d. het onderkennen van gevaar en risico;

2. een positieve attitude ten aanzien van:
a. afstelling van bindingen;
b. risico-gedrag;
c. het opvolgen van adviezen;

3. een positieve intentie ten aanzien van het afstellen van de bindingen.

Bovengenoemde doelstellingen liggen in elkaars verlengde en moeten resulteren in gedrag dat uiteindelijk leidt tot een reductie van het aantal letsels. De gedragsmaten die voor de evaluatie van de interventie gehanteerd worden zijn:

1. afstellen van de bindingen;

2. afstellen door een vakman;

3. afstellen door een vakman met behulp van testapparatuur. 
Het communicatie-doel kan dan als volgt geconcretiseerd worden: "het laten afstellen van de bindingen door een vakman met behulp van testapparatuur".

\section{Afweging van methoden en middelen}

Door de opdrachtgever werd aangegeven dat in de interventie in lieder geval de folder als medium moest worden opgenomen. Het gebruik van folders past in een reeks van voorlichtingsmateriaal, die door de opdrachtgever landelijk wordt verspreid. Een tweede eis was dat de interventie een massamediale impact moest hebben. In de regel worden de doelstellingen afgezet tegen de beschikbare media in die zin dat zorgvuldig een afweging gemaakt wordt ten aanzien van de mediumkeuze. Criteria die bij de mediumkeuze gehanteerd kunnen worden zijn bijvoorbeeld: het bereik, soort overdracht, receptiviteit van de doelgroep, communicatievermogen, functioneel gebruik, frequentiemogelijkheid, kosten etc. In dit onderzoek was een mediumkeuze niet aan de orde omdat de opdrachtgever bij voorbaat al een keuze had gemaakt.

In deze interventie-studie wordt een drietal condities gehanteerd om te bezien op welke wijze een gezondheidseducatieve interventie het beste gerealiseerd kan worden, namelijk:

1. medium;

2. tijdstip van benadering;

3. benaderingswijze.

Deze condities zijn gekozen naar aanleiding van de volgende overwegingen:

ad. 1 Over "gedwongen" blootstelling aan auditieve middelen is in de literatuur weinig bekend. Toch lijkt het ons realistisch om bij wijze van experiment in deze interventie een auditief middel te beproeven. De context van het gebruik is in dit geval aantrekkelijk: $80 \%$ van de wintersporters verplaatst zich per auto, waarvan het overgrote deel voorzien is van een cassette-recorder. Ogenschijnlijk lijkt dit ongerijmd met de werkelijkheid: als de automobilisten de informatie onderweg ontvangen, is het al te laat om nog preventieve maatregelen te treffen. Dit is echter ten dele bezijden de waarheid: mensen die hun bindingen nog niet hebben laten afstellen of mensen waarbij het afstellen niet correct op de persoon is gebeurd, kunnen dit alsnog laten doen in het ski-oord. De informatie op de cassette is niet zicht- 
baar: het vluchtig kennis nemen van de informatie wordt daarmee bemoeilijkt en de nieuwsgierigheid kan worden vastgehouden. Bovendien is het mogelijk om de attractiviteit van de boodschap te verhogen middels sfeervolle muziek De resultaten zullen in dit onderzoek vergeleken worden met de resultaten van een folder.

ad. 2 Een belangrijke oorzaak van het falen van voorlichting is dat het bericht de voorgelichte niet of op een verkeerd tijdstip bereikt. In dit onderzoek zal gezocht worden naar het tijdstip waarbij de ontvanger het meest ontvankelijk is voor de boodschap, met andere woorden wanneer de voor te lichten personen het meest betrokken zijn bij en geïnteresseerd in het onderwerp. De ene helft van de onderzoekspopulatie is drie weken voor het vertrek naar de wintersportplaats benaderd, de andere helft een week van te voren. De keuze van deze tijdstippen is triviaal; weliswaar heeft er een nadere oriëntatie plaatsgevonden bij de doelpopulatie maar er kon niet eenduidig vastgesteld worden dat de gekozen tijdstippen de (enige) juiste waren. In het informatiemateriaal wordt erop gewezen dat men de bindingen het beste in Nederland kan laten afstellen. Wanneer dat niet meer mogelijk is kan men dit ook in het ski-oord laten doen. Bij de eerste groep is het aannemelijk dat de afstelling nog in de woon- of vertrekplaats zal plaatsvinden. Bij de tweede groep bestaat deze

mogelijkheid ook, maar rekening houdend met het feit dat de informatie te laat ontvangen wordt, kan men de bindingen in de plaats van bestemming nog laten afstellen. Gekeken zal worden of er een relatie is tussen het tijdstip van ontvangst en het afstelgedrag.

ad. 3 Uit het onderzoek van Bouter en Knipschild (1985) kwam naar voren dat personen die te kennen gaven voor de vakantie angst voor vallen te hebben gehad, bijna 50\% minder kans op een ongeval hadden. Angst bij de ontvanger is in de sociaal-psychologische literatuur vaak het object van onderzoek geweest, met name het idee dat hogere angst tot de gewenste gedragsverandering zal leiden. In deze studie sluiten we aan bij de bevindingen van R.W.Rogers (1983) die het gedrag verdeeld in ongewenst en gewenst gedrag. Bij beide gedragingen geeft hij aan welke factoren het gedrag belemmeren dan wel begunstigen. Volgens Rogers zal de voorlichter de nadelen van het ongewenste gedrag moeten versterken (angst) en dient hij de voordelen van het gewenste gedrag te benadrukken (eigen effectiviteit). Onderzocht zal worden welk effect angst-aanjagende voor- 
lichting in dit geval heeft. De angst wordt geconcretiseerd door de nadruk te leggen op de ernst van het letsel en de kwetsbaarheid van de persoon. Dit is zowel ethisch als voorlichtingskundig verantwoord, daar hogere angst tot de gewenste gedragsverandering kan leiden omdat de inschatting van de persoonlijke eigen effectiviteit hoog kan zijn, met andere woorden door het gewenste gedrag te vertonen wordt de angst geminimaliseerd. De inschatting van de eigen capaciteit om een specifiek gedrag uit te voeren, staat centraal in het selfefficacy concept van de sociale leertheorie van Bandura (1977). De ervaren self-efficacy bepaalt de keuze van activiteiten, de mate van inspanning, de mate van volhouden, en zo het uiteindelijke gedrag. Self-efficacy wordt in belangrijke mate beînvloed door eigen succes en falen in het verleden, maar ook door voorbeelden van anderen die het gedrag uitvoeren, sociale invloeden en emotionele toestand. Een veranderingsstrategie die de self-efficacy wil verhogen, moet gericht zijn op herkenbare ervaringen en bevindingen, waarbij succes aan aanleg en falen aan gebrek aan inspanning toegeschreven wordt. De kern van de boodschap die wij willen overdragen, leent zich uitstekend voor het verhogen van de persoonlijke effectiviteit. Persoonlijke effectiviteit levert positieve resultaten op voor het opvolgen van de boodschap als er geen twijfel bestaat over de effectiviteit van het aanbevolen gedrag (Sutton, 1982). Met name in de angstaanjagende of harde versie kan de nadruk op persoonlijke effectiviteit bijzonder waardevol zijn: als het aanbevolen gedrag door de ontvanger als erg effectief wordt gezien, dan zal de toenemende angst leiden tot aanvaarding van de boodschap. Wanneer men aan de andere kant de boodschap op voorhand als ineffectief ziet, dan zal de toenemende angst leiden tot defensieve reacties en wordt de boodschap afgewezen (Rogers en Newborn, 1976).

\subsection{De compositie en het pretesten van de boodschap}

Conform de overwegingen in de voorafgaande paragraaf is gekozen voor de volgende boodschap: "Laat Uw skibindingen afstellen door een vakman met een testapparaat".

De intentie om de brochure en de audio-cassette te zijner tijd op grote schaal te verspreiden noodzaakt tot kritische bezinning over de kwaliteit van de informatie. Een kwaliteitsoordeel kan op verschillende aspecten betrekking hebben. Met het oog op een grote massamediale 
campagne in de toekomst is het kwaliteitsoordeel afgestemd op een optimale toegankelijkheid voor een homogene doelgroep. Bij het samenstellen van de boodschap hebben we gebruik gemaakt van a. de matrix van McGuire, met name de factoren die deel uit maken van de onafhankelijke variabele "boodschap", b. eisen die door Janssen en Steehouder (1982) gesteld worden aan voorlichtingsteksten en c. de vier dimensies van begrijpelijkheid van Langer, Schultz von Thun en Tausch (1974).

McGuire ordent en beschrijft de sociaal-psychologische variabelen, die betrekking hebben op attitudeverandering (zie ook Damoiseaux 1988; Lentz, 1989). De variabelen zijn goed bruikbaar als het gaat om persuasieve teksten. In hoofdstuk 5 hebben we er al op gewezen dat de onderzoeksresultaten die samengebracht zijn in de matrix, veelal afkomstig zijn van laboratoriumonderzoek. Dat is waarschijnlijk de reden waarom McGuire weinig aandacht schenkt aan situationele factoren. McGuire geeft zelf ruiterlijk toe dat hij geen linguist is. Voor de taalbeheersingsfacetten van de voorlichtingsteksten zijn we daarom te rade gegaan bij Jansen en Steehouder $(1981,1982)$. Zij hebben op basis van onderzoek naar folderteksten een aantal normen geformuleerd waaraan voorlichtingsteksten moeten voldoen:

1. De tekst weerspiegelt het handelingsverloop van de gebruiker.

2. De tekst wijst de gebruiker de gemakkelijkste route.

3. De tekst geeft bij iedere stap de gemakkelijkste aanwijzing.

4. De tekst is zo expliciet mogelijk.

5. De tekst helpt de gebruiker zo goed mogelijk bij de selectie van de informatie die voor hem belangrijk is.

6. In de tekst wordt een directe stijl gehanteerd.

7. De tekst is zo begrijpelijk mogelijk gepresenteerd.

8. De tekst weerspiegelt inhoud en doel van de regeling (Jansen en Steehouder, 1982, pag. 294-295).

Jansen en Steehouder zijn er niet zeker van dat de acht geformuleerde eisen (normen) volledig zijn. $\mathrm{Zij}$ geven aan dat nader onderzoek moet uitwijzen of er nog andere eisen toegevoegd moeten worden. Ten aanzien van begrijpelijkheid zijn zij tamelijk algemeen. In hoofdstuk 6 hebben we reeds opgemerkt dat het formuleren in termen van begrijpelijkheid en het onderzoek naar begrijpelijkheid zeer moeilijk is. Omdat "begrijpelijkheid" zo'n belangrijk aspect van voorlichting is, hebben we een beroep gedaan op de vier dimensies van begrijpelijkheid zoals die door Langer et al. (1974) zijn geformuleerd. 
Voor ons doel heeft "de methode Langer" het voordeel dat ze gebruikt kan worden voor een ongedifferentieerd publiek In een andere context waar men met subpopulaties werkt, is de methode minder geschikt. Schematisch kan de inhoud van de vier dimensies van begrijpelijkheid als volgt worden weergegeven:

\begin{tabular}{|c|c|}
\hline eenvoud & gecompliceerdheid \\
\hline $\begin{array}{l}\text { eenwoudige beschrijwing } \\
\text { korte, eenwoudige zinnen } \\
\text { gangbare woorden } \\
\text { vaktanl verklaard } \\
\text { concreet } \\
\text { vanschouwelijk }\end{array}$ & $\begin{array}{l}\text { gecompliceerde beschrijving } \\
\text { lange, ingewikkelde zinnen } \\
\text { ongebruikelijke woorden } \\
\text { vaktaal miet verklaard } \\
\text { abstract } \\
\text { niet aansehouwelijk }\end{array}$ \\
\hline opbouw/ordening & $\begin{array}{l}\text { onoverzichtelijk/ } \\
\text { onsamenhangend }\end{array}$ \\
\hline $\begin{array}{l}\text { onderverdeeld } \\
\text { logische volgorde } \\
\text { overzichtellijk } \\
\text { essentiële en niet essentiele } \\
\text { zaken goed onderscheiden } \\
\text { rode draad blijft zichtbraar } \\
\text { het ten volgt goed uit het } \\
\text { ander }\end{array}$ & $\begin{array}{l}\text { niet onderverdeeld } \\
\text { onsamenhangend " verwarrend } \\
\text { onoverzichtelijk } \\
\text { essentiele en niet essentiële } \\
\text { zaken slecht onderscheiden } \\
\text { men verliest valk rode dragd } \\
\text { alles loopt door elkaar }\end{array}$ \\
\hline beknoptheid/kernachtigheid & ornslachtigheid \\
\hline $\begin{array}{l}\text { te kart } \\
\text { tot het essentiẽle beperkt } \\
\text { gecomprimeerd } \\
\text { op 't leerdoel gericht } \\
\text { beknopt } \\
\text { elk woord is noodzakelijk }\end{array}$ & $\begin{array}{l}\text { te lang } \\
\text { veel onbelangrijke informatie } \\
\text { breedsprakerig } \\
\text { afdwalend } \\
\text { uitvoerig. } \\
\text { veel had men weg kunnen } \\
\text { laten }\end{array}$ \\
\hline extra stimulans & geen extra stimulans \\
\hline $\begin{array}{l}\text { inspiverend } \\
\text { interessant } \\
\text { voll afwisseling } \\
\text { persoonlijk }\end{array}$ & $\begin{array}{l}\text { nuchter } \\
\text { kleurloos } \\
\text { gelijkblijvend neutraal } \\
\text { onpersoonlijk }\end{array}$ \\
\hline
\end{tabular}

Figurur 8.4 Dimensies van begrijpelijkheid (Langer et al., 1974). Bron: Van Woerkum et al., 1987, pag. 78. 
De volgende aspecten hebben in onze voorlichtingsproducten (folder en cassette) bijzondere aandacht gekregen: beknoptheid, redundantie, aantrekkelijkheid, structuur en relevantie.

De mate van bondigheid is van grote invloed op de begrijpelijkheid. Bij het aantal teksteenheden is gekozen voor een uitgebalanceerde ontwerptekst, dat wil zeggen niet te lang (de aandacht verslapt) en niet te kort (de tekst wordt onduidelijk of roept teveel vragen op). Alle franje die niet direct met de afstelling van de skibindingen te maken had, is - na zorgvuldige afweging - weggelaten.

In de tekst is sprake van een zekere mate van redundantie. Dit is opzettelijk gebeurd in die zin dat gedetailleerde informatie werd toegevoegd aan de inhoud van de brochure. De redundantie is gebruikt om de centrale boodschap te herhalen (vetgedrukt in koppen) en daardoor meer nadruk te leggen op de kern van de brochure en de cassette. Omwille van de begrijpelijkheid en duidelijkheid is in de tekst sprake van parafrase (het weergeven van de inhoud in andere woorden). Bij het componeren van de tekst en het samenstellen van de folder is niet alleen een appèl gedaan op de cognities van de ontvanger, maar is ook een beroep gedaan op de affectieve beleving.

Om de tekst goed te laten doordringen en de motivatie te verhogen om de tekst helemaal door te lezen, is de aantrekkelijkheid van de brochure verhoogd door:

a. gebruik te maken van illustraties (een foto en drie tekeningen);

b. aandacht te schenken aan een juiste toonzetting;

c. gebruik te maken van kleurendruk;

d. gebruik te maken van vetgedrukte koppen (omwille van de overzichtelijkheid);

e. in te spelen op bijzonderheden en/of voorbeelden die de (potentiële) skiër zeker zullen interesseren.

Bij de cassette zijn de illustraties e.d. vervangen door stukjes muziek. In ons streven om de boodschap zo eenvoudig mogelijk samen te stellen zijn moeilijke en vage, abstracte woorden vermeden ( $\mathrm{zo}$ is bijvoorbeeld het woord "tibia" vervangen door "de doorsnede van het scheenbeen"). Ook is er op gelet om zoveel mogelijk korte zinnen te gebruiken.

De begrijpelijkheid van de boodschap wordt verhoogd door een logische, overzichtelijke en op het doel en publiek afgestemde structuur (Langer et all, 1974). In de tekst is gestreefd naar een logische 
opbouw wan relaties in de zin van causaliteit, redengeving, finaliteit en categorisering (Drop en De Vries, 1977).

Uitgangspunt voor de uiterlijke structuur van de boodschap was:

a. de geleding; de verschillende onderdelen van de tekst moeten als afzonderlijke onderdelen goed herkenbaar zijn; dit gebeurt enerzijds door de verdeling van de tekst (paragrafen, alinea's) en anderzijds door explicitering van de inhoudelijke kenmerken die dergelijke onderdelen tot een eenheid maken;

b. de ordening: hierbij is uitgegaan van het principe van progressieve differentiatie, waarbij men in een tekst de informatie eerst globaal aanbiedt (bijvoorbeeld in de inleiding en door overgangszinnen), waarna verdere details volgen.

In onze brochure heeft deze structuur concreet vorm gekregen door korte stukken tekst, waarin een facet van de boodschap wordt belicht, te voorzien van een pakkende, vetgedrukte kop. In het streven om de boodschap opzettelijk beknopt en eenvoudig samen te stellen schuilt het gevaar dat men niet tegemoet komt aan de behoeften van de doelgroep. Met name de tekst op de frontpagina van de folder en het doosje van de cassette, wekt de indruk alsof een definitief antwoord gegeven wordt op het probleem van ski-blessures. Wij hebben ons echter laten leiden door het algemeen aanvaarde idee dat een brochure geen Delfisch naslagwerk is, maar een passend antwoord moet geven op vragen die redelijkerwijze als relevant voor het probleem worden ervaren. Op kritisch wijze zijn die onderwerpen en thema's geselecteerd die - op geleide van de literatuur en op voordracht van inhoudsdeskundigen - van belang zijn voor het afstellen van de bindingen. Ons heeft voor ogen gestaan om uitsluitend die zaken aan de orde te stellen die een directe relatie met het afstellen van skibindingen hebben. Dit heeft geresulteerd in:

a. effectiviteit van goed afgestelde bindingen;

b. kennis over de werking van de skibinding en het nut van persoonlijke afstelling;

c. ontmythologiseren van mogelijke misverstanden;

d. korte adviezen betreffende het nemen van voorzorgsmaatregelen om optimaal te profiteren van het afstellen van de skibindingen;

e. wijzen op mogelijke barrières die het geïntentioneerde gedrag kunnen verhinderen;

f. benadrukken van het feit dat skiën onvermijdelijk risico's met zich meebrengt en de skiër aanspreken om risico's zoveel mogelijk te 


\section{reduceren.}

Bij het samenstellen van de tekst hebben we ons ten aanzien van de betrouwbaarheid laten leiden door de overweging dat alleen die informatie wordt opgenomen die, empirisch onderbouwd, leidt tot vermindering van letsel, of een faciliterend effect heeft op het gewenste resultaat.

Middels literatuurstudie is nagegaan welke informatle in het licht van de bovengenoemde criteria in aanmerking komt voor publicatie in de brochure. Deze informatie is getoetst aan de hedendaagse normen van juistheid door terzake deskundigen (vakhandelaren, ANWB, Nederlandse Ski Vereniging en ervaren skiërs). Voorts is het idee van "a priori-aannemelijkheid", dat wil zeggen het geloof in of de instemming met een uitspraak op grond van eigen voorkennis of bestaande attitude van de ontvanger, in de tekst verweven (Steehouder et al., 1979).

Om te achterhalen welke benaderingswijze het meest geschikt is voor een gezondheidseducatieve interventie hebben we gevarieerd in de mate van angstaanjagende voorlichting. In de angstversie hebben we de ernst van het letsel en de kwetsbaarheid van de persoon beklemtoond. Enkele voorbeelden van de verschillen ten aanzien van het angst-aspect:

\section{geen angst}

" $U$ heeft $U w$ veiligheid in eigen hand"

Wie geen goede conditie heeft, roekeloos is en met materiaal skiet dat niet in orde is, loopt onnodig risico"

"Laat U niets wijsmaken, het is Uw veiligheid die op het spel staat"

\section{angstaanjagend}

"U heeft Uw ongeluk in eigen hand"

"Als Uw conditie niet goed is, als $\mathrm{U}$ roekeloos bent en als $\mathrm{U} w$ materiaal niet in orde is, heeft $U$ een ongeluk puur aan Uzelf te wijtten"

"Laat $U$ niets wijsmaken, het zijn Uw armen, benen, ribben, portemonnee en vakantieplezier die op het spel staan" 
Belangrijk bij het opvolgen van aanbevolen boodschappen is aan te geven van hoe het gewenste gedrag moet worden uitgevoerd. In het algemeen kan men stellen dat specifieke instructies van de aanbevolen boodschap meer inzicht verschaffen in het uitvoeren van gedrag, waardoor men gemakkelijker het besluit neemt om het gewenste gedrag te vertonen (Sutton, 1982).

In onze boodschap is de specifieke instructie gegeven om het afstellen van de bindingen over te laten aan de vakman, die over testapparatuur beschikt. Ook is getracht om mogelijke barrières te torpederen door erop te wijzen dat het afstellen van de bindingen weinig geld en moeite kost.

\section{Het pretesten van de boodschap}

Pretesten is een vorm van formatieve evaluatie om vroegtijdig en systematisch reacties van de doelgroep en deskundigen te verzamelen over bedoelde en onbedoelde gevolgen van de communicatieboodschap. Voor een nadere toelichting op de gevolgde werkwijze verwijzen we naar hoofdstuk 6.

Uit de onderzoekspopulatie zijn at random 70 personen gekozen voor het pretest-onderzoek. Zij zijn voor deelname aan het verdere onderzoek uitgesloten. Voor het pretesten van de folder zijn 40 mensen gekozen en voor het pretesten van de cassette 30 .

Voor het testen van de folder is onderscheid gemaakt in twee groepen: twintig personen kregen de folder met de angstaanjagende versie en twintig mensen de folder met de gewone versie. Daarnaast werden aan zes externe deskundigen beide folders toegestuurd. In de wetenschap dat het om een niet-"real life"- conditie ging, heeft het accent bij deze pretest gelegen op de onmiddellijke reacties. In de begeleidende brief aan de deelnemers van de pretest werd dan ook vermeld dat de mensen op de dag van ontvangst telefonisch benaderd zouden worden om hun mening over de folder kenbaar te maken. Wellicht ten overvloede zij er op gewezen dat pretesten min of meer een vorm van "gedwongen blootstelling" is. Dit impliceert dat het aangeboden materiaal kritischer wordt bekeken en dat het niet mogelijk is om bijvoorbeeld de attentie-waarde te meten. We hebben ons dan ook beperkt tot de meest essentile zaken, zoals die genoemd zijn in de Health Message Testing Service. Dit is een in Amerika ontwikkelde, gestandaardiseerde vragenlijst voor het pretesten van voorlichtingsmateriaal (US Department of Health and Human Services, 1984). Aan de orde zijn gesteld onder andere begrijpelijkheid, persoonlijke relevan- 
tie, hoeveelheid informatie en overtuigingskracht van de boodschap. Voor nadere details, zie hoofdstuk 6.

Het pretesten heeft er toe geleid dat de tekst op een aantal punten is gewijzigd. Met name is een nauwe aansluiting gezocht met de illustraties en zijn enkele correcties aangebracht, die mogelijkerwijze bij vluchtig lezen -verkeerd geïnterpreteerd kunnen worden. Het feit dat de respondenten nagenoeg unaniem positief stonden ten aanzien van de verschillende aspecten van de pretest, heeft de gedachte doen postvatten of de gevolgde pretest methode voldoende betrouwbaar en valide was. Bij nadere, kritische beschouwing vonden we geen reden om te twijfelen aan de kwaliteit van de pretest.

Ook de cassettes zijn aan een pretest onderworpen, nadat de tekst van de folder was bijgesteld. Tussen folder en cassette zijn qua inhoud van de tekst geen verschillen, behalve dan dat de illustraties vervangen zijn door passende muziek. Bij de cassette is nagegaan of de kern van de boodschap goed overkwam en of er mogelijke fouten zijn gemaakt bij het vertalen van de tekst van schrijftaal naar spreektaal. De cassettes zijn bij 30 personen getest. De resultaten van deze pretest gaven geen aanleiding om de vorm of de inhoud van de cassette te wijzigen.

\subsection{Methode van het onderzoek}

Om te bepalen welke voorlichtingsmethode het meest effectief is, is gebruik gemaakt van een quasi-experimentele onderzoeksopzet (Cook en Campbell, 1979). Door drie onafhankelijke variabelen ieder op twee niveau's te variëren, zijn acht experimentele groepen samengesteld: medium (cassette en folder), tijd (én week voor vertrek en drie weken voor vertrek) en angst (hoog en laag)". Tevens is een controlegroep samengesteld, welke geen voorlichting ontving. Het design wordt weergegeven in figuur 8.5.

Zowel boodschap 1 als boodschap 2 bevatten informatie over het belang van het afstellen van ski-bindingen door de vakman, de noodzaak om de bindingen voor de vakantie af te laten stellen, informatie over de werking en de afstelling van de bindingen en enkele algemene voorzorgsmaatregelen (zie paragraaf 8.3).

Met hoog en laag wordt bedoeld: angstaanjagend respectievelijk niet angstaanjagend. 


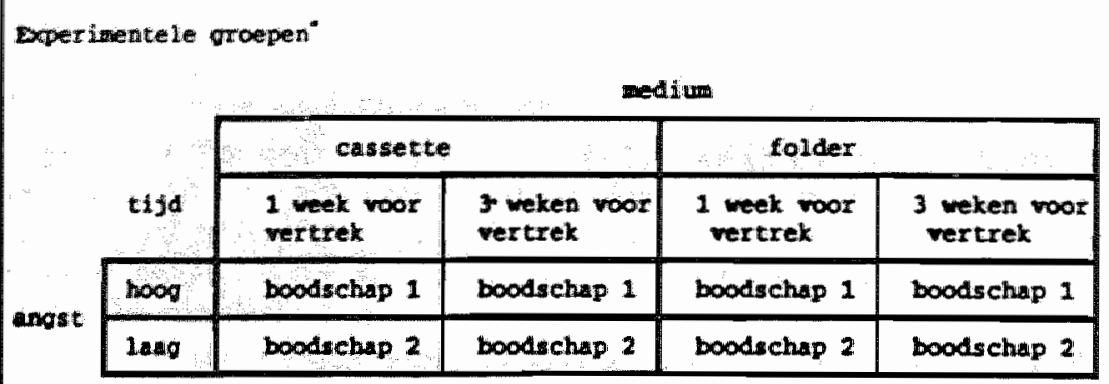

Controlegroep

geen boodschap

Figuur 8.5 Onderzoeksdesign

De onderzoekspopulatie wordt gevormd door Nederlanders van 18 jaar en ouder, die in december, januari of februari van het seizoen 1986-1987 op wintersportvakantie zouden gaan, met als hoofddoel alpine-skiën. Diegenen die tijdens hun wintersportvakantie alleen zouden gaan langlaufen of andere doeleinden voor ogen hadden (sleeën, wandelen, rusten), werden van deelname aan het onderzoek uitgesloten. Om de respondenten te verzamelen zijn gedurende zeven dagen twee skibeurzen bezocht. Dit zijn groots opgezette beurzen, waar informatie te verkrijgen is over alles wat met skiën te maken heeft, van materiaal en kleding tot hotels en pensions.

Er is weinig reden om aan te nemen dat de bezoekers van skibeurzen zich op enigerlei wijze onderscheiden van de overige Nederlandse alpine-skiërs. Om een goede spreiding wat betreft urbanisatiegraad te garanderen werd de werving verspreid over een skibeurs in Kerkrade, welke meer een regionaal en plattelands karakter draagt en over een skibeurs in Rotterdam, welke meer nationaal en stedelijk van aard is. Tijdens de skibeurzen werd elke vijfde persoon die de beurs verliet benaderd door een interviewster. In totaal werkten zeven inter- 
viewsters mee. Uitgaande van \pm 150 mensen per onderzoeksgroep, moesten 1380 mensen benaderd worden. Bij het bepalen van de steekproefgrootte (onderzoekspopulatie), te verdelen over acht onderzoeksgroepen, is uitgegaan van aantallen die een voldoende stabiele schatting van het interventie-effect garanderen. Uiteraard is daarbij rekening gehouden met mogelijke uitval tijdens de interventie en de follow-up periode.

Aan deze mensen werden enkele algemene vragen gesteld en het verzoek om medewerking te verlenen aan een telefonische enquête. Om bias te voorkomen werd hen alleen verteld dat het onderzoek handelde over skiën en veiligheid en niet dat het met name ging over de ski-bindingen.

In totaal werden 1380 mensen bereid gevonden om mee te werken aan het onderzoek. Voor het pretesten waren 70 mensen nodig. Bij het opschonen van de populatiegegevens bleken 22 mensen toch niet aan de gestelde criteria te voldoen. Zij waren jonger dan 18 jaar, gingen langlaufen, vierden vakantie buiten de onderzoeksperiode, of waren niet telefonisch bereikbaar. Uiteindelijk bleven er 1288 personen over die geschikt waren voor het onderzoek (netto onderzoekspopulatie). Aan de experimentele groepen werden circa 145 personen toegewezen. Voor de controle-groep resteerden er 136.

Allereerst is de totale onderzoekspopulatie random verdeeld in een controlegroep en een experimentele groep. Om de splitsing binnen de experimentele groep naar de conditie "medium" te vereenvoudigen is in de algemene vragenlijst gevraagd naar het vervoer en, indien men met de auto ging, naar de aanwezigheid van een cassette-recorder in de auto. Op basis hiervan is de groep onderverdeeld in een cassettegroep (personen die met de auto met cassette-recorder op vakantie zou gaan) en een foldergroep (personen die op een andere wijze zou gaan). Aangezien de cassette-groep groter was dan de foldergroep, is random een aantal mensen uit deze groep toegewezen aan de foldergroep, zodat er twee gelijke groepen overbleven.

Binnen deze twee groepen is per computer een randomverdeling gemaakt in vier subgroepen. Op deze manier konden zowel binnen de cassette-groep, als binnen de foldergroep de mensen random verdeeld worden over de condities tijd en angst (zie figuur 8.6).

Zo bleven er uiteindelijk acht experimentele groepen over van ieder \pm 145 personen. Deze experimentele groepen kregen voor hun vertrek naar de wintersport namens de Stichting Consument en Veiligheid 
een folder of cassette toegestuurd. Om het vermoeden weg te nemen dat deze zending verband hield met ons onderzoek, werd de naam van de universiteit noch in of op de folder en de cassette, noch in de begeleidende brief vermeld.

Randomisatie:

1 controle-groep

8 experimentele groepen, selectief toegewezen op basis van auto/cassette: kort-angst-cassette kort-niet-angst-cassette lang-angst-cassettelang-niet-angst-cassette kort-angst-folder kort-niet-angst-folder lang-angst-folder lang-niet-angst-folder

Figur 8.6 Randomisatie

Aan alle potentiële respondenten op de skibeurzen werd allereerst gevraagd of ze van plan waren om in de periode december, januari of februari te gaan skiën. Degenen die alleen wilden gaan langlaufen of om een andere reden op wintersport gingen en degenen die in een andere periode wilden gaan, werden niet verder ondervraagd.

Aan de geschikte respondenten werd de vermoedelijke vertrekdatum gevraagd, dit was noodzakelijk om de verzenddata van het voorlichtingsmateriaal te bepalen.

Verder werden enkele algemene demografische en vakantiegegevens verzameld, namelijk geslacht, leeftijd, vakantieduur, land van bestemming, vervoer, aantal reisgenoten, ski-ervaring en het bezit van ski's.

De meting werd door middel van een telefonische enquête onder alle 1288 personen afgenomen. De vragenlijst is op de skibeurs bij 152 mensen uitgetest (pilot). De relevantie van de gekozen variabelen vloeit voort uit de probleem-en gedragsdeterminantenanalyse (zie 
paragraaf 8.2). De vragenlijst was als volgt opgebouwd (de antwoordcategorieën waren voorgestructureerd):

1 de skivakantie: is men werkelijk op vakantie geweest, heeft men kunnen skiên, hoeveel dagen, heeft men extra moeite moeten doen om te kunnen skiën;

2 sportbeoefening: aantal uren per week, inschatting eigen lichamelijke conditie;

3 lichamelijke voorbereiding op de wintersportvakantie;

4 vragen over de ski's waarmee men geskied heeft: had men die gekocht, gehuurd of geleend;

5 gedrag: heeft men de skibindingen laten afgestellen, door wie, op welke wijze, indien men ze niet heeft laten afstellen is gevraagd waarom niet en of men het wel van plan was;

6 sociale omgeving: m.b.t. het voorkomen van blessures en afstellen van skibindingen;

7 vaardigheid: kleur piste waarop men skiet;

8 risico: heeft men op pistes geskied die eigenlijk te moeilijk waren;

9 blessures: angst voor blessures, heeft men een blessure opgelopen, aard en ernst blessure, vermoedelijke oorzaak gevolgen voor het skiën;

10 het opvolgen van adviezen: beliefs ten aanzien van algemene adviezen en ten aanzien van adviezen over blessures;

11 ontvankelijkheid: heeft men de afgelopen tijd iets gehoord, gezien of gelezen over het voorkomen van ski-ongevallen, bron;

12 kennis- en attitudevragen m.b.t. skibindingen;

13 vragen over de cassette of folder: ontvangst, tijdstip, beluisterd $\mathrm{cq}$ gelezen, bewaard, over de inhoud gesproken, belangrijkste informatie, heeft de cassette cq. folder de deelnemer overtuigd van het nut van het afstellen van de skibindingen, was men vanwege de cassette cq folder van plan om de skibindingen af te laten stellen;

14 algemeen persoonsgebonden kenmerken: opleidingsniveau, geslacht, leeftijd.

$\mathrm{Na}$ afloop van het ski-seizoen hebben elf interviewsters gedurende 22 dagen telefonische enquêtes afgenomen. De interviewsters werden geselecteerd op stemhelderheid en goede contactuele eigenschappen. In een introductie-bijeenkomst zijn de interviewsters voorbereid op mogelijke misverstanden en zijn afspraken gemaakt over de interpretatie van de antwoorden. Voor de telefonische enquête is gebruik gemaakt van het Ci2-programma van Sawtooth Software Inc (1986). 
Dit is een interactief computergestuurd interview-systeem. Om zoveel mogelijk mensen te bereiken en evenveel mannen als vrouwen in het onderzoek te betrekken, werd zowell 's middags als 's avonds gebeld.

\subsection{Resulltaten}

De respons van de telefonische enquête voor alle groepen was hoog, namelijk $91,5 \%$. Deze bijzonder hoge respons wordt verklaard door het feit dat de respondenten hun medewerking aan het onderzoek reeds hadden toegezegd en van te voren wisten dat zij telefonisch geènquêteerd zouden worden.

In totaal zijn 1288 skiërs gebeld, 110 personen lieten het afweten (non-respons $=8.5 \%$ ). De non-respons bestond voor $72 \%$ uit personen die niet telefonisch bereikt konden worden en voor $28 \%$ uit personen die alsnog hun deelname aan het onderzoek weigerden. Van de 1178 skiërs gaven er 26 te kennen dat zij iets anders toegezonden hadden gekregen, dan wij ze volgens onze gegevens hadden toegestuurd. Deze personen zijn van analyse uitgesloten. Uiteindelijk bleven er 1152 skiërs over die voor analyse geschikt waren (89\%).

De respons is goed verdeeld over de afzonderlijke groepen, zij het dat de respons bij de experimentele groepen (gemiddeld $92 \%$ ) aanmerkelijk hoger ligt dan bij de controlegroep (84\%). Dit verschil berust waarschijnlijk op toeval: binnen de controlegroep was een relatief groot aantal personen dat niet telefonisch bereikt kon worden. Bij vergelijking van de respons met de non-respons op enkele demografische en persoonlijke kenmerken (geslacht, gemiddelde leeftijd, vervoerswijze, vakantieduur, land van bestemming en ski-ervaring), kwamen geen verschillen naar voren.

Om interviewersbias te voorkomen werden alle elf interviewsters van te voren uitgebreid geinstrueerd. Uit vraaggesprekken met de interviewsters tussentijds en na afloop en uit de statistische gegevens kwamen geen verschillen naar voren wat betreft interpretatie en beantwoording van de vragen.

Zoals reeds eerder vermeld in paragraaf 8.5 , was er voor ons geen reden om aan te nemen dat de bezoekers van skibeurzen zich op enigerlei wijze zouden onderscheiden van de overige Nederlandse skiêrs. Om deze aanname te toetsen hebben wij een vergelijking gemaakt met twee andere onderzoeken (Bouter, 1985; CBS, 1986), waarbij de respondenten op geheel andere wijzen zijn verzameld. Uit 
deze beschouwing kwamen geen verschillen naar voren wat betreft geslacht, gemiddelde leeftijd, vervoer, vakantieduur, land van bestemming of ski-ervaring.

Alleen wat betreft het opleidingsniveau van de respondenten werden verschillen gevonden met het vakantie-onderzoek van het CBS (1986) (zie tabel 8.1).

Tabel 8.1 Vergelijking opleidingsniveau respondenten onderhavig onderzoek en respondenten vakantie-onderzoek CBS, 1986.

\begin{tabular}{|lcc|}
\hline $\begin{array}{l}\text { opleidings- } \\
\text { niveau }\end{array}$ & $\begin{array}{c}\text { onderhavig } \\
\text { onderzoek (\%) }\end{array}$ & $\begin{array}{c}\text { valkantie-onderzoek } \\
\text { CBS 1986 (\%) }\end{array}$ \\
lager & 15 & 41 \\
midden & 52 & 29 \\
hoger & 33 & 29 \\
\hline
\end{tabular}

Het vakantie-onderzoek van het CBS had zowel betrekking op zomervakanties als op wintervakanties. De gegevens, zoals hierboven weergegeven, hebben echter allen betrekking op de wintersportvakantie.

In ons onderzoek is, in vergelijking met de CBS-gegevens, die op dezelfde wijze zijn gecategoriseerd, een ondervertegenwoordiging van de laag opgeleiden en een oververtegenwoordiging van de mensen met een middelbare opleiding te zien. Bovengenoemd verschil is te verklaren uit het feit dat $25 \%$ van de respondenten uit het CBSonderzoek jonger is dan 18 jaar, terwijl in dit onderzoek mensen beneden de 18 jaar zijn uitgesloten. Logischerwijs geeft dit voor het opleidingsniveau een vertekening naar beneden.

Bij vergelijking van geslacht, gemiddelde leeftijd, vervoerswijze, vakantieduur, land van bestemming en ski-ervaring, kwamen ook geen verschillen naar voren tussen de controle-groep en de experimentele groepen. 
De onderzoekspopulatie bestond uit 1152 personen $(56,4 \%$ mannen en 43,5\% vrouwen) van 18 jaar en ouder die in december, januari of februari van het seizoen 1986-1987 op wintersportvakantie zouden gaan, met als hoofddoel alpine-skiën. Slechts 3,5\% van de respondenten ging naast skiën ook langlaufen.

Het zijn met name jonge mensen die gaan skiën: meer dan de helft van de deelnemers aan het onderzoek is jonger dan 35 jaar. Slechts $2,7 \%$ is ouder dan 55 jaar (zie tabel 8.2).

Tabel 8.2 Respondenten $(\mathrm{n}=1149)$ naar leeftijd in $\%$.

\begin{tabular}{|lc|}
\hline $18-25$ jaar & 27 \\
$26-35$ jaar & 31 \\
$36-45$ jaar & 28 \\
$46-55$ jaar & 12 \\
56 jaar en ouder & 3 \\
\hline
\end{tabular}

Alpine-skiën wordt over het algemeen beschouwd als een elitaire sport, vanwege het feit dat de kosten voor het beoefenen van deze sport betrekkelijk hoog zijn. Niet alleen is de aanschaf van de uitrusting vrij kostbaar, ook de reis- en verblijfskosten zijn in vergelijking met zomervakanties en andere sporten aan de hoge kant. Ook de feitelijke uitoefening van deze sport gaat gepaard met hoge kosten. In dit onderzoek is vanwege privacy-overwegingen niet gevraagd naar het inkomen van de respondenten, maar wel naar het opleidingsniveau.

Het opleidingsniveau is weliswaar niet gelijk aan het inkomensniveau, maar het geeft wel een redelijke indicatie daarvan (zie tabel 8.3).

Lit tabel 8.3 blijkt dat de veronderstelling dat skeën een elite-sport is, niet helemaal gerechtvaardigd is. Meer dan de helft van de respondenten heeft een middelbare opleiding (MBO, MAVO, MULO of HAVO) gevolgd. Ruim 15\% heeft een lagere opleiding genoten (lagere 
school of LBO) en ruim 30\% een hogere opleiding (Atheneum, VWO, $\mathrm{HBS}, \mathrm{HBO}$, Universiteit of Hogeschool).

Tabel 8.3 Respondenten ( $\mathrm{n}=1111)$ naar opleidingsniveau in $\%$.

\begin{tabular}{|lr|}
\hline & \\
lagere school & 2 \\
LBO & 13 \\
MBO & 25 \\
MAVO / MULO & 18 \\
HAVO & 8 \\
Atheneum / VWO / HBS & 6 \\
\hline
\end{tabular}

In het begin van het wintersportseizoen werden de wintersporters opgeschrikt door de mededeling dat de sneeuwval in de wintersportgebieden uiterst gering was. Deze onheilstijding zou wellicht mensen ervan hebben kunnen weerhouden om hun voorgenomen plannen ten uitvoer te brengen. Daarom is aan de respondenten gevraagd of ze ook werkelijk op skivakantie zijn geweest. Slechts een klein percentage $(8,1 \%)$ heeft van vakantie afgezien. Bijna de helft om persoonlijke redenen en $18,3 \%$ vanwege de geringe sneeuwval.

Van degenen die wel gegaan zijn heeft bijna iedereen $(98,7 \%)$ kunnen skiën. Wel zegt bijna $20 \%$ dat ze extra moeite hebben moeten doen om te kunnen skièn, door bijvoorbeeld naar hoger gelegen pistes of naar andere plaatsen te gaan. De meeste respondenten hadden in het verleden al eerder geskied $(92,2 \%)$. Voor $7,8 \%$ was dit seizoen de eerste keer. Maar ook skiërs met een ruime ervaring kunnen wat betreft vaardigheid nog tot de beginners behoren. Daarom is gevraagd naar de moeilijkheidsgraad van de pistes waarop men voornamelijk geskied heeft. Het gros van de respondenten begeeft zich op de gemiddelde of makkelijke piste, slechts een klein percentage $(3,6 \%)$ waagt zich op de moeilijke pistes. Er blijkt een sterke relatie te zijn 
tussen de ski-ervaring en de moeilijkheidsgraad van de pistes. Naarmate men meer ski-ervaring heeft, begeeft men zich vaker op moeilijkere pistes.

Veel skiêrs $(70,2 \%)$ zeggen nooit op een piste te skiën die eigenlijk te moeilijk voor hen is. Ruim een kwart $(27,7 \%)$ zegt dit af en toe te doen en slechts $2,1 \%$ doet dit vaak. Naarmate men vaker op wintersport gaat zal de neiging afnemen om op pistes te skiën die eigenlijk te moeilijk zijn.

Door diverse instanties wordt gewezen op het belang van een goede lichamelijke voorbereiding op de wintersport. Zo worden er overal in het land cursussen en/of trainingen georganiseerd ter voorbereiding op de wintersport. Met name ski-gymnastiek en ski-aerobic winnen de laatste jaren aan populariteit.

Bijna eenderde van de respondenten blijkt specifieke lichamelijke voorbereidingen te treffen, zoals ski-gymnastiek of oefenen op de kunst-skibaan. Ruim de helft treft geen enkele extra lichamelijke voorbereiding. Er konden geen significante verschillen geregistreerd worden tussen het al dan niet afstellen van de bindingen en het treffen van lichamelijke voorbereidingen.

Het merendeel van de respondenten $(77 \%)$ doet naast skiën ook nog aan andere sporten. Mensen die helemaal niet aan sport doen, treffen ook geen lichamelijke voorbereidingen voor de wintersport.

Aan alle respondenten is gevraagd een inschatting te maken van hun eigen lichamelijke conditie. De meeste respondenten schatten hun lichamelijke conditie in als redelijk tot normaal. Slechts eenderde noemt zijn of haar conditie goed. Mensen met een slechte conditie hebben geen grotere kans op het krijgen van een blessure dan mensen met een redelijke, normale of goede conditie.

Er zijn geen significante verschillen gevonden tussen de inschatting van de lichamelijke conditie en de moeilijkheidsgraad van de piste, de lichamelijke voorbereidingen die men trof voor de wintersport en het afstellen van de bindingen.

Aangezien onze interventie zich beperkte tot het afstellen van de skibindingen, is wat de uitrusting betreft uitsluitend ingegaan op de ski's zelf en zijn vragen over de skistokken, kleding, etc. achterwege gelaten. Het al dan niet bezitten van eigen ski's kan van invloed zijn op het afstellen van de bindingen. De veronderstelling hierbij is dat personen die zelf ski's hebben ook zelf zorg moeten dragen voor een juiste afstelling van de ski-bindingen. Bij huurski's verkregen via de vakhandel in Nederland wordt het afstellen van de bindingen vaak 
als service meegenomen. Het juist afstellen van de bindingen via sportzaken in buitenlandse, drukke vakantie-oorden, behoort tot de uitzonderingen. Ook bij het lenen van ski's van familie, vrienden of kennissen, wordt de afstelling van de bindingen vaak over het hoofd gezien. De meerderheid van onze respondenten (79\%) heeft zelf ski's. Bijna $20 \%$ van de overige respondenten heeft ski's gehuurd en slechts een kleine groep (2\%) leent ski's van familie of bekenden. Wellicht ten overvloede zij er op gewezen dat deze vraag betrekking had op de ski's, die daadwerkelijk gebruikt zijn tijdens de wintersport.

De centrale boodschap in de interventie was: "Laat uw bindingen afstellen door de vakman met behulp van een testapparaat". Zowel in de folder als in de cassette werd duidelijk aangegeven aan welke voorwaarden goed afgestelde bindingen moeten voldoen. Bij het afstellen van de bindingen moet rekening worden gehouden met een aantal persoonlijke factoren, die de instelwaarde bepalen zodat maximale veiligheid gegarandeerd kan worden.

De belangrijkste indicatoren voor de instelwaarde zijn de doorsnede van de bovenkant van het scheenbeen (de tibia). Het lichaamsgewicht wordt vaak als equivalent gebruikt voor de omvang van de tibia. Voorts zijn van belang het geslacht, de leeftijd, de skivaardigheid en de zoollengte van de skischoen.

De skivaardigheid is in dit onderzoek niet opgenomen omdat in de praktijk vaak blijkt dat men met de vaardigheid nogal eens makkelijk de hand licht. Mensen die voor de tweede of derde keer gaan skiën, willen bijvoorbeeld niet aangesproken worden als "beginner". Men classificeert zich doorgaans in een te hoge categorie. Ook het aantal seizoenen dat men de skisport beoefent is geen goede graadmeter voor ski-vaardigheid. De reden waarom bij de respondenten toch geinformeerd is naar het aantal malen dat men de sikisport beoefend heeft, heeft te maken met de veronderstelling dat mensen die vaker op wintersport zijn geweest meer kennis hebben over allerlei facetten van het skièn.

Uit literatuuronderzoek was al gebleken dat een aanzienlijk deel van de skiërs de bindingen laat afstellen. Het probleem is echter dat de meeste mensen het niet op de goede manier doen of in de veronderstelling verkeren dat het goed gebeurd is in het verleden. Deze feitelijkheden zijn ontleend aan voorbereidende besprekingen met deskundigen (vakhandelaren, toeristenorganisaties en vertegenwoordigers). Een veel voorkomend misverstand is bijvoorbeeld het idee dat 
in de jaarlijkse onderhoudsbeurt ook het afstellen is inbegrepen. In dit onderzoek is nagegaan of het afstellen is gebeurd conform de adviezen die in de folder of cassette vermeld waren. Op onze vraag of men de skibindingen heeft laten afstellen, antwoordt $83 \%$ bevestigend (zie figuur 8.7).

$\begin{array}{ll}\text { niet laten afstellen } & 17 \% \\ \text { wel laten afstellen } & 83 \%\end{array}$

zelf afgesteld $\quad 5.0 \%$

door vrienden, kennissen etc. $\quad 2.1 \%$

door de vakhandel in Nederland $61.0 \%$

door vakhandel in buitenland $31.9 \%$

met testapparaat $35 \%$

Figuur 8.7 overzicht afstelgedrag $(n=1043)$.

Aan degenen, die wel de bindingen hebben laten afstellen door de vakhandel $(92 \%)$ is gevraagd of er naar het lichaamsgewicht gevraagd is. $\mathrm{Bij} 83 \%$ was dit wel het geval, bij $15,3 \%$ niet en $1,7 \%$ wist het niet (meer). Aan dezelfde groep mensen werd gevraagd of men de omvang van het scheenbeen (tibia) heeft opgemeten. Bij meer dan de helft was dit het geval; bij $42,0 \%$ was dit nagelaten en $0,9 \%$ wist het niet (meer).

Aan diegenen, die bevestigend antwoordden op de vraag of de bindingen zijn afgesteld, is de vraag voorgelegd of de afstelling gecontroleerd werd met een testapparaat. Bij $35 \%$ is dit inderdaad gebeurd. Figuur 8.7 geeft een overzicht van het afstelgedrag.

Er zijn geen significante verschillen tussen mensen die de bindingen al dan niet laten afstellen en het skiën op pistes die de competentie van de skièr overschrijdt. Ook geldt dit ten aanzien van de perceptie om risico's te nemen.

Er bestaan ook geen significante verschillen tussen mensen die al dan 
niet de bindingen laten afstellen en het al dan niet krijgen van een blessure. Bij de interpretatie van dit gegeven moet men uiterste voorzichtigheid betrachten en well om twee redenen. Allereerst is de strekking van de interventie gericht op het persoonlijk afstellen van bindingen met testapparatuur door de vakman. In de tweede plaats is de incidentie van blessures in vergelijking met de omvang van de populatie te klein.

Tabel 8.4 Blessure naar soort in \% $(n=89)$.

\begin{tabular}{|lr|}
\hline kneuzing, verrekking, verstuiking & 55,1 \\
botbreuk & 7,9 \\
gescheurde spier & 6,7 \\
ontwrichting & 5,6 \\
gescheurde gewrichtsband & 3,4 \\
snijwond & 3,4 \\
hersenschudding & 0,0 \\
onbekend & 18,0 \\
\hline
\end{tabular}

Tabel 8.5 Blessures naar localisatie in \% $(n=89)$.

\begin{tabular}{|lr|}
\hline knie & 29 \\
been & 16 \\
borst / schouder & 16 \\
duim & 12 \\
nek / hoofd & 3 \\
anders & 24 \\
& \\
\hline
\end{tabular}


Ook is de veronderstelling getoetst of mensen die bang zijn voor het krijgen van een blessure er toe overgaan om de bindingen te laten afstellen. Ook hier werden geen significante verschillen gevonden.

Aan de respondenten is gevraagd of men tijdens het skiën een blessure heeft opgelopen. Bij 91,5\% was dit niet het geval. Aangezien het moeilijk is om achteraf vast te stellen hoe ernstig de blessure was of hoeveel last men ervan gehad heeft, is geïnformeerd naar het soort blessure en de localisatie van het letsel (zie tabellen 8.4 en 8.5).

Wat betreft het soort blessure kan geconstateerd worden dat ongeveer de helft minder ernstig van aard is. Dit wordt ondersteund door het feit dat de blessure bij $50 \%$ van de respondenten niet van invloed is geweest om met skiên door te gaan. Voor ongeveer $28 \%$ gold dat men gedeeltelijk heeft moeten afzien van het skiën. Aan de geblesseerden is gevraagd naar de oorzaak van de blessure. Onderstaande tabel bevat een overzicht van de spontane antwoorden van de respondenten (tabel 8.6). Het registreren van deze gepercipieerde oorzaken maakt het onderscheid tussen directe en indirecte oorzaken twijfelachtig. Zo kan bijvoorbeeld een val als oorzaak worden genoemd, terwijl mogelijkerwijs roekeloosheid als oorzaak van de val kan worden aangewezen.

Tabel 8.6 Blessure naar oorzaak in $\%(n=89)$.

\begin{tabular}{|lc|}
\hline val & 34 \\
piste, weer, sneeuwlaag & 18 \\
botsing & 10 \\
te veel risico & 10 \\
materiaal (excl. bindingen) & 8 \\
bindingen & 7 \\
overige oorzaken & 12 \\
geen ldee & 1 \\
\hline
\end{tabular}


Bij ruim $40 \%$ van de respondenten is het letsel veroorzaakt door een val of een botsing. De bindingen worden slechts in $7 \%$ van de gevallen als oorzaak gezien. Hierbij moet opgemerkt worden dat de cijfers wellicht een vertekend beeld geven. Wanneer men bijvoorbeeld valt en de bindingen gaan daarbij niet los, wordt de oorzaak waarschijnlijk omschreven als "val", terwijl het in werkelijkheid aan de bindingen lag of dat de val het gevolg is van roekeloos gedrag.

Mensen die tijdens de wintersport een blessure hebben opgelopen zijn vergeleken met mensen die ongeschonden de wintersport zijn doorgekomen op de volgende variabelen: wel of niet sporten, risicogedrag, lichamelijke voorbereiding, geslacht, leeftijd, ski-ervaring, ingeschatte conditie en de moeilijkheidsgraad van de piste. Wintersporters van 45 jaar en ouder hebben iets meer kans op het krijgen van een blessure dan jongeren tussen de 18 en 44 jaar $(p \leq 0.05)$. Ten aanzien van de andere bovengenoemde variabelen zijn er geen significante verschillen gevonden tussen geblesseerden en niet-geblesseerden.

Wel was er een licht significant verschill te constateren tussen degenen aan wie uitdrukkelijk verteld is hoe ze blessures kunnen voorkomen en mensen aan wie dit niet uitdrukkelijk verteld is. Het betrof hier de dyadische communicatie met mensen waarvan men het skiën geleerd heeft (bijvoorbeeld ski-leraren). Mensen aan wie uitdrukkelijk verteld wordt hoe ze blessures kunnen voorkomen, lopen minder kans om een blessure op te lopen.

\subsection{De effecten van de voorlichting}

Aan alle respondenten uit de acht experimentele groepen $(n=1040$, $90 \%$ van de totale groep respondenten) is namens de Stichting Consument en Veiligheid een folder of een cassette toegestuurd. De controlegroep $(n=110,10 \%)$ heeft niets ontvangen. Voor aandacht, begrip, attitudeverandering, intentieverandering en gedragswerandering is met behulp van ANOVA-analyses nagegaan wat de invloed van de drie condities (tijd, angst en medium) was. Voor zover relevant worden ook de verschillen tussen de controlegroep en alle experimentele groepen tezamen gegeven.

Het begrip aandacht is op verschillende manieren gemeten. Allereerst is aan de respondenten uit de experimentele groepen gevraagd of zij zich konden herinneren dat aan hen een folder of een cassette was toegestuurd. Ruim $75 \%$ kon zich dit inderdaad herinneren, de overige 
respondenten wisten het niet meer.

Interessant is nu om te bezien welke invloed de drie verschillende condities hebben op de herinnering (zie tabel 8.7).

Tabel 8.7 Percentage respondenten dat zich kan herinneren het voorlichtingsmateriaal te hebben ontvangen $(n=1040)$.

\begin{tabular}{|cccc|}
\hline & & korte tijd & lange tijd \\
cassette & hoge angst & 95 & 97 \\
& lage angst & 95 & 95 \\
& hoge angst & 54 & 57 \\
folder & lage angst & 55 & 55 \\
& & & \\
& & & \\
\end{tabular}

Uit deze tabel blijkt dat wat betreft herinnering de cassette de meeste indruk heeft achtergelaten $(\mathrm{F}(1,146)=288.2, \mathrm{p}<.001)$. Gemiddeld 95\% van de respondenten aan wie een cassette was toegestuurd, kan zich dat nog herinneren. Van de respondenten die een folder hadden gekregen, wist dit nog slechts de helft (gemiddeld 55\%). Of de folder kort of lang voor de skivakantie was toegezonden en of de inhoud al dan niet angstaanjagend was, blijkt geen invloed te hebben op de herinnering.

Aan die respondenten die zich konden herinneren iets ontvangen te hebben, is gevraagd of zij de folder gelezen hadden dan wel de cassette beluisterd hadden.

Bijna alle respondenten die zich de ontvangst konden herinneren, geven aan het materiaal helemaal $(81 \%)$ of gedeeltelijk $(11 \%)$ gelezen of belluisterd te hebben. Onderstaande tabel (tabel 8.8) geeft de verschillen per conditie wat betreft lezen/uisteren aan, uitgedrukt in 
gemiddelden waarbij het cijfer 1 . staat voor niet gelezen c.q. beluisterd, het cijfer 2. voor gedeeltelijk en het cijfer 3 . voor helemaal.

Wederom blijkt er alleen een hoofdeffect van de conditie medium te zijn $(\mathrm{F}(1,784)=5,2, \mathrm{p}<.05)$. Had de cassette de hoogste score wat betreft de herinnering, bij de aandacht gemeten in termen van lezing c.q. beluistering, scoort de folder het hoogste. De folder is door meer respondenten gelezen dan de cassette is beluisterd. Hierbij moet worden opgemerkt dat deze vraag alleen is gesteld aan de mensen die zich konden herinneren iets ontvangen te hebben; in absolute aantallen is de cassette vaker beluisterd.

Ook is gevraagd of men de folder of de cassette heeft bewaard danwel weggegooid. Een groot deel van de respondenten (88\%) blijkt het voorlichtingsmateriaal te hebben bewaard. Tabel 8.9 geeft een overzicht per conditie.

Tabel 8.8 Respondenten, die zich de ontvangst konden herinneren, naar lezing c.q. beluistering van het voorlichtingsmateriaal $(n=785)$.

\section{korte tijd lange tijd}

hoge angst $\quad 2.62 \quad 2.68$

cassette

$\begin{array}{lll}\text { lage angst } & 2.70 & 2.71 \\ \text { hoge angst } & 2.79 & 2.77\end{array}$

folder

lage angst $\quad 2.78 \quad 2.79$

De cassette is significant vaker bewaard dan de folder $(F(1,714)=75.3$, $\mathrm{p}<.001$ ), ongeacht het tijdstip waarop het werd verzonden en ongeacht het angstgehalte van de boodschap. De cassette werd door 
gemiddeld $96 \%$ van de respondenten bewaard, de folder door gemiddeld $75 \%$.

Tabel 8.9 Percentage respondenten dat het voorlichtingsmateriaal heeft bewaard ( $n=715)$.

korte tijd lange tijd

hoge angst $\quad 98 \quad 94$

cassette

lage angst $\quad 94 \quad 97$

hoge angst $\quad 75 \quad 70$

folder

lage angst $\quad 72 \quad 83$

Tenslotte is gevraagd of men met andere mensen over de inhoud van de cassette of folder heeft gesproken. Bijna tweederde $(68 \%)$ van de respondenten geeft te kennen dit te hebben gedaan, terwijl $32 \%$ zegt er met niemand over gesproken te hebben. Tabel 8.10 geeft een overzicht van de invloed van de verschillende condities.

Uit deze tabel blijkt dat respondenten die een cassette hadden ontvangen significant vaker met anderen over de inhoud hebben gesproken (gemiddeld $75 \%$ ) dan respondenten die een folder hadden ontvangen (gemiddeld $56 \%$ ), ongeacht tijdstip of angstgehalte.

Samenvattend kan gesteld worden dat de ontvangst van de cassette, in termen van herinnering, veel meer indruk op de respondenten gemaakt heeft dan de ontvangst van de folder. Bijna alle betreffende respondenten herinnerden zich de cassette, de folder herinnerden zich slechts de helft. Ook is de cassette vaker bewaard dan de folder en is vaker met anderen over de inhoud gesproken. Daarentegen is de 
folder door meer mensen gelezen, dan de cassette beluisterd is. Men moet hierbij wel bedenken dat deze vraag alleen is gesteld aan degenen die zich de ontvangst van het voorlichtingsmateriaal konden herinneren, in absolute aantallen is de cassette vaker beluisterd. Het tijdstip van ontvangst en het angst-gehalte van de boodschap blijken op geen enkele van bovengenoemde aandachtsaspecten invloed te hebben.

Tabel 8.10 Percentage respondenten dat met anderen over de inhoud van het voorlichtingsmateriaal heeft gesproken $(n=715)$.

\begin{tabular}{|cccc|}
\hline & & korte tijd & lange tijd \\
cassette & hoge angst & 77 & 80 \\
& lage angst & 68 & 75 \\
& hoge angst & 56 & 56 \\
folder & lage angst & 51 & 61 \\
\hline
\end{tabular}

Om het begrip van de boodschap te meten is een aantal kennisvragen gesteld, die betrekking hadden op hetgeen in het voorlichtingsmateriaal werd behandeld. Ter vergelijking zijn deze vragen ook aan de controlegroep gesteld. $\mathrm{Na}$ betrouwbaarheidsanallyse bleven van de acht gestelde kennisvragen vijf vragen over die, als kennisschaal, een redelijke betrouwbaarheid hadden $(\alpha=.56)$. In onderstaande tabel worden de frequenties van deze vijf vragen weergegeven (tabel 8.11). N.B. Goed betekent hier dat de respondent de vraag goed beantwoord heeft. 
Tabel 8.11 Frequentieverdeling kennisvragen in $\%(\mathrm{n}=1040)$.

weet goed fout
niet

1. Tegenwoordig zijn de bindingen zo goed dat ze niet iedere keer opnieuw afgesteld hoeven te worden $\quad 74,8 \quad 10,3 \quad 14,9$

2. De afstelling van ski-bindingen hoeft niet persé gecontroleerd te worden met een testapparaat $59,3 \quad 20,3 \quad 20,4$

3. Het is noodzakelijk om de skibindingen voor iedere skivakantie opnieuw af te stellen

4. Alleen zeer ervaren skiërs kunnen hun ski-bindingen zelf afstellen $49,5 \quad 18,3 \quad 32,2$

5. Je hoeft je ski-bindingen alleen te laten controleren, wanneer je zelf twijfelt aan de juiste afstelling 74,8 $5,2 \quad 20,0$

Wordt de gesommeerde kennis in de controlegroep vergeleken met de gesommeerde kennis in alle experimentele groepen samen, dan blijkt de kennis in de experimentele groepen significant hoger te zijn 
$(t(1019)=2.34, p<.05)$. Nagegaan is ook of er binnen de verschillende condities verschillen in kennisniveau waar te nemen zijn (zie tabel 8.12). De tabel geeft de gemiddelde scores op de kennisschaal weer, de schaal heeft een waardebereik van -5 (alle vragen fout) tot +5 (alle vragen goed); een hoge score duidt aldus op een hoog kennisniveau.

Tabel 8.12 Respondenten naar kennisniveau op de gesommeende kennisitems $(n=1040)(\min =-5, \max =+5)$.

\begin{tabular}{|cccc|}
\hline & & korte tijd & lange tijd \\
& hoge angst & 2,55 & 2,47 \\
cassette & & & \\
& lage angst & 1,90 & 2,42 \\
& hoge angst & 2,53 & 2,21 \\
& lage angst & 1,85 & 2,53 \\
\hline
\end{tabular}

Er blijkt een significante interactie te zijn tussen tijd en angst $(F(1,1040)=6.9, p<.05)$. Dat wil zeggen dat een combinatie van beide factoren van invloed is op het kennisniveau. Inspectie van de gemiddelden laat zien dat er bij twee van de acht groepen een lager kennisniveau is dan bij de overige experimentele groepen. Zoals blijkt uit de tabel, is de kennis het laagste in de groepen die kort van tevoren informatiemateriaal met een laag angstgehalte hebben ontvangen. De kennis in deze twee groepen verschilt niet significant van de controlegroep. Of men een folder of cassette gehad heeft blijkt voor de kennis niet uit te maken.

Samenvattend kan worden gezegd dat de experimentele groepen meer kennis hebben dan de controlegroep. Het medium blijkt geen invloed op het kennisniveau te hebben. De boodschap die kort van tevoren 
was verzonden met een laag angst-gehalte sorteert het minste effect. Met behulp van drie vragen is getracht de attitude te meten. Het betrof hier de attitude ten aanzien van de relatie tussen het afstellen van bindingen en het voorkomen van blessures. In tabel 8.13 wordt een overzicht gegeven van de frequentieverdeling van de drie attitudevragen.

Tabel 8.13 Frequentieverdeling attitude in $\%(n=1150)$.

eens geen oneens
mening

1. Wanneer bindingen goed zijn afgesteld wordt de kans op ernstige blessures, zoals beenbreuk, kleiner $95,5 \quad 2,2 \quad 2,3$

2. Wanneer bindingen goed zijn afgesteld wordt de kans op lichte blessures, zoals verstuiking, dikke knie, kleiner $74,7 \quad 5,3 \quad 20,0$

3. Het al dan niet krijgen van een ongeluk heeft sterk te maken met het goed afstellen van de bindingen door de vakman $81,1 \quad 4,7 \quad 14,2$

Betrouwbaarheidsanalyse over deze drie vragen liet zien dat er geen sprake was van een uni-dimensionele schaal. Hierdoor was het niet 
mogelijk de vragen tot een schaal te sommeren. Overigens kan een scheve verdeling ook verantwoordelijk zijn voor het gebrek aan schaalbaarheid. Vervolgens is per vraag afzonderlijk gekeken naar de relatie tussen deze vragen en de stappen begrip, intentie en gedrag. Het bleek dat geen van de vragen, in tegenstelling tot de verwachting, een relatie met de genoemde stappen had. Hierop is besloten de vragen in de verdere analyse buiten beschouwing te laten.

Tabel 8.14 Percentage respondenten met een positieve intentie tot het afstellen van de bindingen plus respondenten die de bindingen daadwerkelijk afgesteld hebben $(n=1050)$.

\begin{tabular}{|cccc|}
\hline & & korte tijd & lange tijd \\
cassette & hoge angst & 84 & 88 \\
& lage angst & 76 & 87 \\
& hoge angst & 94 & 88 \\
folder & & 79 & 87 \\
\hline
\end{tabular}

In eerste instantie is aan de respondenten gevraagd of men de skibindingen heeft laten afstellen. Indien men hier ontkennend op antwoordde, is geinformeerd of men wel van plan was om ze af te laten stellen. Het percentage afstellers plus degenen die de intentie hadden tot afstellen bedroeg $85 \%$. Bij $15 \%$ van de skiërs heeft de voorlichting geen positieve effecten gesorteerd. Er zijn geen significante verschillen gevonden tussen de intentie en gedrag van de controlegroep en die van alle experimentele groepen samen. De invloed van de experimentele condities op de intentie tot afstellen en afstelgedrag wordt weergegeven in tabel 8.14.

Er is sprake van een hoofdeffect van zowel tijd als angst (respec- 
tievelijk $F(1,953)=4.3 p<.05$ en $F(1,953)=6.7, p<.01)$. Inspectie van de gemiddelden laat zien dat vooral voorlichtingsmateriaal dat kort van tevoren is verzonden en een laag angstgehalte bezit, verantwoordelijk is voor deze hoofdeffecten. In dat geval is er, ten opzichte van de overige groepen, het minste effect op de intentie en gedrag om de skibindingen te laten afstellen.

Samengevat blijkt dat de meeste respondenten een positieve intentie tot afstellen hebben. Een verschil tussen de controlegroep en alle experimentele groepen samen is niet gevonden. Voorlichtingsmateriaal dat kort van tevoren is verzonden en voorlichtingsmateriaal met een laag angst-gehalte, heeft de minste invloed op de intentie. Het medium heeft totaal geen invloed op de intentie.

Aan de respondenten is gevraagd of ze hun bindingen daadwerkelijk hebben afgesteld en zo ja, door wie ze dat dan hebben laten doen (zie tabel 8.15).

Tabel 8.15 Respondenten naar afstellen van de bindingen in \% $(n=1040)$.

niet afgesteld

zelf, vrienden afgesteld

vakman afgesteld zonder testapparaat

vakman afgesteld met testapparaat
17.2

4.6

43.1

35.1

Ruim 17 procent van de respondenten heeft de bindingen niet laten afstellen. Daarentegen heeft ruim $35 \%$ van de respondenten de bindingen door een vakman laten afstellen met behulp van testapparatuur. Er zijn geen significante verschillen gevonden tussen het al dan niet afstellen door de controle-groep en alle experimentele groepen samen. Idem dito geldt dit voor het afstellen door de vakman. Er is geen significant verschil in het gebruik van testapparatuur: de 
experimentele groepen hebben hier niet significant vaker gebruik van gemaakt dan de controlegroep. Wel waren er verschillen in positieve zin tussen de controlegroep en de experimentele cassette-groep, maar deze zijn niet significant De invloed van de verschillende condities wordt weergegeven in tabel 8.16, waarbij een hoge score duidt op een betere afstelling.

Tabel 8.16 Respondenten naar afstelgedrag $(n=952)$.

\section{korte tijd lange tijd}

hoge angst $\quad 2.94 \quad 3.06$

cassette

lage angst $\quad 2.76 \quad 2.97$

hoge angst $\quad 3.05 \quad 3.08$

folder

lage angst $\quad 2.83 \quad 2.94$

Wellicht ten overvloede zij vermeld dat deze tabel betrekking heeft op alle skiërs minus degenen die hun bindingen niet hebben afgesteld. Er blijkt een significante invloed te zijn van de conditie angst $(\mathrm{F}(1,939)=5.6 \mathrm{p}<.05)$.

Voorlichtingsmateriaal met een hoog angstgehalte scoort, wat betreft het afstellen van de bindingen, hoger dan materiaal met lage angst en dan de controlegroep. De condities met hoge angst scoren dus, ongeacht tijd en medium significant hoger dan lage angst en de controlegroep. 


\subsection{Discussie en conclusies}

Aan het ontwerpen van het onderzoek, de uitwoering van de interventie en de analyse van gegevens is zorgvuldig aandacht besteed. Toch is een aantal kritische kanttekeningen op zijn plaats. Ten eerste de vraag of de respondenten in ons onderzoek representatief zijn voor de Nederlandse skierrs. Ten aanzien van de demografische kenmerken konden we geen verschillen constateren. Echter, het is wel denkbaar dat een bepaalde populatie met latente kenmerken zich aangetrokken voelt tot manifestaties als skibeurzen e.d. Zo wordt bijvoorbeeld de skibeurs gedomineerd door een ruim assortiment kleding. De indruk bestaat dat het vooral kooplustigen zijn die, na een enkele maal geskied te hebben, willen overgaan tot de aanschaf van ski-materiaal.

Een tweede opmerking betreft de omvang van de steekproef. Deze is voornamelijk bepaald door de statistisch vereiste aantallen per experimentele conditie. Het vergroten van de onderzoekspopulatie, om de preciesie van de metingen te verhogen, was om financiële redenen onmogelijk. De relatief kleine omvang van de onderzoekspopulatie gezien in het licht van het incidentiecijfer - brengt met zich mee dat er geen empirisch gefundeerde uitspraken kunnen worden gedaan over een eventuele reductie van het aantal blessures.

De validiteit van dit onderzoek kan enigszins in twijfel getrokken worden doordat achteraf gevraagd is naar belevingen en ervaringen. Zo kan het bijvoorbeeld gebeuren dat een skiër die bij een ongeluk betrokken is geweest, achteraf heel anders is gaan denken over het opvolgen van adviezen of het afstellen van de bindingen.

Ten aanzien van de externe validiteit van een interventie-onderzoek is voorzichtigheid gepast vanwege het feit dat de respondenten voor de interventie zijn gevraagd om hun medewerking te verlenen. In dit onderzoek zijn we op onze hoede geweest om deze zogenaamde "reactive effects" te minimaliseren. Aan de respondenten is welliswaar medegedeeld dat het een onderzoek betrof ter voorkoming van skiblessures, maar er is niet verteld dat het om een interventie over het afstellen van de bindingen ging. Het is niet geheel uitgesloten dat hiermee het sociaal-wenselijkheids-effect toch nog onvoldoende is geëlimineerd.

In ons onderzoek hebben we een drietal vragen opgenomen waarmee we de attitude ten aanzien van het afstellen van bindingen probeerden te meten. 
Een attitude is een theoretisch construct, om de persoonlijke geneigdheid om op een bepaalde manier te reageren, te meten. Een attitude betreft dus een afweging tussen voor- en nadelen die aan een bepaald gedrag verbonden zijn. Ten aanzien van de onderhavige problematiek dringt zich de vraag op of er inderdaad sprake is van een afweging die mensen mogelijkerwijze zouden kunnen hebben ten aanzien van het afstellen van bindingen. Een eventuele afweging berust dan voornamelijk op het minimaliseren van het risico om letsel op te lopen versus de moeite die men zich moet getroosten om de bindingen af te stellen. Het niet afstellen leidt niet per definitie tot een blessure.

Een tweede kanttekening ten aanzien van attitudes is van methodologische aard, namelijk dat een telefonische enquête zich niet goed leent voor een attitudemeting. Bij het uittesten van de vragenlijst is ons gebleken dat de ondervraagde proefpersonen geen nuances aanbrengen in de beantwoording op een vijf-puntsschaal. Het merendeel van de mensen beantwoordde de vragen uitsluitend met juist - onjuist, eens - oneens of ja of nee. Wij zijn geneigd om de door ons als attitude betitelde vragen als beliefs (opvattingen) aan te merken.

Een kritische noot is ook te plaatsen bij de uitvoering van de interventie als het gaat om de vraag of het toesturen van informatiemateriaal voldoende plausibel is om als publiekscampagne aangemerkt te worden. Bij publiekscampagnes, cq. massa-mediale voorlichting, geldt dat de zender in principe niemand van ontvangst uitsluit. Het toezenden van folders en cassettes naar het huisadres voldoet niet aan deze norm. Critici hebben dan ook gelijk als ze zeggen dat dit onderzoek betrekking heeft op een artificiële situatie; er is immers sprake van gedwongen blootstelling. De attentie-waarde kan bijvoorbeeld niet achterhaald worden. Dit manco is op te vatten als signaal om bij een toekomstige interventie extra aandacht te besteden aan de ontvankelijkheid voor de informatie naar plaats en tijd.

In dit onderzoek is getracht het juiste tijdstip te vinden waarop mensen geinteresseerd zijn in informatie met betrekking tot de wintersport. $\mathrm{Er}$ is een schatting gemaakt van twee tijdstippen, met een interval van twee weken. Ofschoon er lichte verschillen zijn in de afhankelijke variabelen, kunnen we geen afdoend antwoord geven op de vraag welk tijdstip nu het meest geschikt is om de informatie te verspreiden. Wellicht is onze veronderstelling dat wintersporters pas drie weken voor vertrek voorbereidingen treffen voor de vakantie, gebaseerd op drijfzand. 
Ook willen we er nog op wijzen dat de keuze voor het medium en de plaats van verspreiding (in geval van schriftelijk voorlichtingsmateriaal) van groot belang is.

Een jaar of tien geleden was het beoefenen van de skisport voorbehouden aan mensen die over ruime financiële middelen beschikten. Skièn werd dan ook aangeduid als een elite-sport. Thans stellen wij vast dat skiën zich in een steeds groeiende populariteit mag verheugen. Gezien de gestage groei van het aantal skiërs mogen we spreken van een volkssport.

Naast bedenkingen die men uit milieu-oogpunt kan hebben (bijwoorbeeld ontsieringen van de bergflanken door het aantal liften, het gebruik van de auto als vervoermiddel), heeft skiën, net als andere sporten, zijn schaduwzijden in de vorm van letsels en ongelukken. In vergelijking met andere sporten zijn de sociaal-economische consequenties betrekkelijk hoog. Afgezien van de transportkosten gaan ernstige skiletsels gepaard met langdurig ziekteverzuim en hoge geneeskundige kosten. In deze studie zijn we ervan uitgegaan dat een belangrijk deel van het aantal blessures geminimaliseerd kan worden door een doelgerichte, planmatige en systematische interventie. Het betreft dan die letsels, waarbij het gedrag van de skiër aangemerkt kan worden als oorzaak van de blessure. Het gedrag moeten we niet beperken tot feitelijk handelen; ook affectieve en cognitieve aspecten rekenen we daartoe. In de eerste fase van het onderzoek hebben we gezocht naar die factoren die zowel beinvloedbaar als veranderbaar zijn. Dit impliceert dat we de interventie toegespitst hebben op die adviezen die, empirisch onderbouwd, leiden tot het gewenste effect. Het resultaat daarvan was het advies: het afstellen van de bindingen door de vakman met testapparatuur.

Gezien de onstuimige groei van het aantal skërs uit alle lagen van de bevolking, is het idee van een publiekscampagne in principe voor uitvoering vatbaar. De kracht van de massa-media schuilt in het massale bereik met ongedifferentieerde doelgroepen. Uit dit onderzoek blijkt dat het beoefenen van de wintersport veelal een kwestie is van particulier initiatief.

Het percentage mensen dat in ongeorganiseerd verband gaat, is nagenoeg te verwaarlozen. Dit impliceert dat een interventie gericht op gesegmenteerde doelgroepen praktisch onuitvoerbaar is.

Driekwart van de skiërs uit ons onderzoek besteedt meer dan een uur per week aan sport; doorgaans mag men aannemen dat het meren- 
deel van de actieve sporters ook passief sport consumeert via radio, televisie, publiekstijdschriften en kranten. Deze veronderstelling wordt gevoed door het gegeven dat meer dan de helft van de onderzocht populatie informatie over het voorkomen van ski-ongelukken via (massa-mediale) bronnen ontvangt.

Over de effecten van massa-media zijn de meningen nog steeds verdeeld. Wetenschappelijke publicaties spreken elkaar tegen als het gaat om effecten op het gedrag van mensen. Wel is er consensus over het feit dat boodschappen via de massa-media, direct of indirect, kunnen leiden tot cognitieve veranderingen en bewustwording. Onze interventie bevestigd dit gegeven: de kennis in de experimentele groepen blijkt significant hoger te zijn dan in de controlegroep. Ten aanzien van de attitude hebben we geen relaties gevonden met het afstelgedrag. Een gefundeerd advies ten aanzien van attitude-vorming moeten we dan ook schuldig blijven.

Voorlichtingsmateriaal met angst heeft de meeste invloed gehad op het afstelgedrag, ongeacht tijdstip en medium. Wat betreft het medium (folder versus cassette), kunnen we het volgende concluderen: de cassette scoort hoog wat betreft de aandacht en agenda-setting. Naar ons idee is het verrassingseffect hier debet aan. Wanneer mensen vaker voorlichting ontwangen via een cassette zal dit effect vermoedelijk wegebben. De folder als voorlichtingsmedium blijft, uit het oogpunt van kosten en praktische uitvoerbaarheid, favoriet.

In de literatuur wordt er vaak op gewezen dat massa-mediale campagnes alleén zinvol zijn, als er gezorgd wordt voor een effectieve ondersteuningsstructuur. Op grond van onze bevindingen pleiten we dan ook voor een multi-mediale aanpak met een gerichte ondersteuningsstructuur. De campagne zal dan in die vorm een looptijd van enkele jaren moeten hebben. 



\title{
Hoofdstuk 9 Patiëntenvoorlichting via de massamedia
}

\author{
9.1 Inleiding \\ 9.2 Probleemstelling \\ 9.3 Methoden \\ 9.4 Resultaten
}

9.4.1 De opinie van huisartsen

9.4.2 De opinie van het publiek

9.4.3 De voorkeur voor informatieve programma's

9.5 Slotbeschouwing

\subsection{Inleiding}

Televisieprogramma's over gezondheid en ziekte zijn in Nederland erg populair. Kijkdichtheidscijfers en waarderingscijfers van tv-programma"s over gezondheid en ziekte tonen overduidelijk aan dat het publiek een grote belangstelling voor dit soort programma's heeft. Een gedramatiseerde documentaire over kanker trok onlangs 2.5 miljoen kijkers met een extreem hoog waarderingscijfer (8.0). De tv-programma"s, die handelen over gezondheid en ziekte kunnen grofweg verdeeld worden in twee categorieën, namelijk medische programma's en gezondheidsprogramma's. Medische programma's verschaffen voornamelijk informatie over curatieve onderwerpen; ze hebben geen educatieve doelstelling in de zin van het bevorderen van gezond gedrag of het voorkomen van ziekten. Gezondheidsprogramma's richten zich op voorlichting en preventie en hebben naast een infor- 
matieve ook een educatieve doelstelling. Ze willen de kijker wijzen op het voorkomen van ziekten en sporen aan tot gezond gedrag. Opmerkelijk is dat medische programma's doorgaans hoger scoren wat betreft kijk- en waarderingscijfers. Ten dele is dit te verklaren door het verschil in aanpak en opzet van de programma's. Medische programma's zijn doorgaans spectaculair; zij brengen soms op sensationele wijze de nieuwste vindingen van de medische technologie in beeld of raken de emotionele snaar door afschrikwekkende beelden te laten zien van ongeneeslijke ziekten. Gezondheidsprogramma"s worden gekenmerkt door een sobere aanpak en een waarschuwende toonzetting, die bij vele mensen als betuttelend overkomt. Beide soorten programma's hebben gemeen dat ze bij het publiek verschillende reacties kunnen uitlokken. Het in dit onderzoek besproken programma, dat zowell kenmerken heeft van een medisch als gezondheidsprogramma, krijgt per uitzending 2000 tot 20.000 schriftelijke reacties. Naast reacties bij de omroep brengen deze programma's ook reacties teweeg bij hulpverleners. Er wordt beweerd dat na een uitzending de wachtkamers van de huisartsen overvol raken (Heuser, 1981). Ofschoon er geen empirische gegevens voorhanden zijn, die deze bewering staven, bleek na een vluchtige telefonische informatieronde bij twintig willekeurig gekozen artsen dat de invloed van de media duidelijk merkbaar was op het spreekuur. De meeste artsen gaven te kennen dat men niet altijd even gelukkig was met deze onverwachte respons. In het algemeen mag men stellen dat de artsen zich kritisch opstellen als het gaat over massamediale programma's; zij verwijten de journalisten dat ze op sensatie uit zijn, dat ze onjuiste informatie geven, dat ze angst, twijfel en onzekerheid teweeg brengen en dat met name bij hypochonders valse hoop gekoesterd wordt. $\mathrm{Zij}$ schrijven de toename van de medische consumptie en het mondiger worden van patiënten onder andere toe aan de invloed van de media. Bij het publiek geldt gezondheid nog steeds als hoogste goed; de behoefte aan informatie over de diverse aspecten van gezondheid en ziekte is erg groot zoals uit de kijk- en luistercijfers blijkt. In dit artikel wordt verslag gedaan van een onderzoek naar de opvattingen van huisartsen over tv-programma's en naar de aard en omvang van de reacties die naar aanleiding van zo'n programma bij de huisarts binnenkomen. Tegelijkertijd werd bij het publiek onderzoek gedaan naar de opinies ten aanzien van gezondheids/medische programma's. 


\subsection{Probleemstelling}

In Nederland is betrekkelijk weinig onderzoek gedaan naar de mogelijke effecten van tv-programma's op het gezondheidsgedrag van mensen. Er zijn geen analyses bekend die inzicht verschaffen in de mogelijke effecten op de medische consumptie cq de consultatie van de huisarts. De huisarts neemt in de Nederlandse gezondheidszorg een centrale positie in. Het is dus te verwachten dat mogelijke reacties, veroorzaakt door een tv-programma, bij de huisarts binnenkomen. Programma"s kunnen zowel negatieve als positieve effecten bij het publiek sorteren. Voorbeelden van positieve effecten zijn : het bewustworden van de eigen verantwoordelijkheid, het nemen van preventieve maatregelen, het vroegtijdig onderkennen van symptomen en het bevorderen van een kritische houding ten aanzien van medische voorzieningen en diensten. Ten aanzien van het vroegtijdig onderkennen van symptomen dient opgemerkt te worden dat dit ook een negatief effect kan hebben, omdat dit hypochondrie in de hand kan werken.

Tot de negatieve effecten kunnen gerekend worden: het consulteren van een arts door verkeerd interpreteren van de informatie, een ongewenste toeloop op allerlei medische voorzieningen en het, veelal suggestieve, denkbeeld dat voor elk medisch probleem wel een medicijn of behandeling is.

De effecten van de massamedia moeten echter met de grootste voorzichtigheid geinterpreteerd worden. Uit de literatuur (Tones, 1981; MoCron, 1981; Turnbull, 1985; Mendelsohn, 1985) blijkt dat de media nauwelijks in staat moeten worden geacht om veranderingen te bewerkstelligen op de attitude en het gedrag van het publiek. Doorgaans reikt de invloed van de media niet veel verder dan het cognitieve domein.

De probleemstelling voor dit onderzoek kan als volgt geformuleerd worden:

a. Wat is de mening van de huisarts over voorlichting via de massamedia?

b. In welke mate wordt het consultatiegedrag van patiënten beïnvloed door gezondheidsprogramma's?

c. Wat is de opinie van het publiek over deze programma's, en hoe reageert men op deze programma"s? 
Om een aantal redenen hebben we ons in deze pilot-studie moeten beperken tot slechts eén uitzending. De voornaamste reden was dat wij de toch al zwaar op de proef gestelde onderzoeksgroep "de huisartsen" niet meer willen belasten dan strikt nodig was. Bovendien leefde de vrees dat huisartsen slechts eenmalig hun medewerking zouden verlenen omdat $z e$ in hun vrije tijd naar het bewuste programma moesten kjjken. De keuze voor de uitzending van het programma was volsterkt willekeurig. De betreffende omroeporganisatie kon ons op voorhand niet zeggen welke onderwerpen in de uitzending aan bod kwamen. Het programma heeft een gevarieerd aanbod in programma-items (ongeveer 3 items per uitzending) en behandelt zowel preventieve als curatieve onderwerpen. Het programma heeft als doelstelling de mondigheid van de patiënt te vergroten en de kijkers in de gelegenheid te stellen zich een mening te vormen over relevante zaken in de gezondheidszorg. Dit populaire programma verschijnt bijna 15 jaar op de Nederlandse beeldbuis en wordt maandelijks als magazine uitgezonden. Het programma had als thema "Aangeboren hartafwijkingen bij kinderen".

\subsection{Methoden}

Uit de totale populatie huisartsen is een representatieve steekproef getrokken $(n=252)$. Deze huisartsen zijn van tevoren schriftelijk verzocht hun medewerking te verlenen aan dit onderzoek. Deze medewerking bestond uit het kijken naar de gekozen aflevering van het tv-programma en het beantwoorden van een telefonische enquete. Ongeveer tweederde van de aangeschreven artsen reageerde positief op dit verzoek. Echter de netto respons, dat will zeggen de artsen, die gekeken hebben en deelnamen aan de enquête, bedroeg slechts $32 \%$. De onderzochte steekproef is alleen afwijkend van de totale praktizerende huisartsenpopulatie op de variabele leeftijd. Het aantal huisartsen jonger dan 40 jaar is namelijk oververtegenwoordigd.

De helft van de deelnemende huisartsen is direct na de uitzending gebeld om te achterhalen welke de verwachtingen waren ten aanzien van mogelijke reacties op het spreekuur. De anderen zijn binnen twee dagen na de uitzending telefonisch ondervraagd om te verifiëren of er ook daadwerkelijke reacties geweest zijn. 
Het onderzochte publiek $(n=600)$ is aselect getrokken uit een representatief bestand van de Nederlandse Omroep Stichting. Deze mensen zijn een week voor de uitzending benaderd met een kijkverzoek. Ongeveer $44 \%$ (199) heefte positief op dit verzoek gereageerd.

\subsection{Resultaten}

Wat betreft de beoordeling van dit programma kunnen we constateren dat het publiek het programma aanmerkelijk positiever beoordeelt dan de huisartsen. Van het publiek beoordeelt bijna $83 \%$ het programma als zeer de moeite waard. Slechts $41 \%$ van de artsen laat zich positief uit over dit programma. Ten aanzien van de presentatie en de betrouwbaarheid van de informatie zijn de meningen nagenoeg hetzelfde, zoals onderstaande tabel laat zien.

Tabel 9.1 Beoordeling programma "Vinger aan de pols" ten aanzien van deskundige presentatie en betrouwbaarheid van de informatie door publiek en huisartsen (in \%).

\begin{tabular}{|c|c|c|c|c|}
\hline & $\begin{array}{l}\text { deskundige } \\
\text { publiek } \\
(\mathrm{n}=194)\end{array}$ & $\begin{array}{c}\text { presentatie } \\
\text { huisartsen } \\
(n=69)\end{array}$ & $\begin{array}{l}\text { betrouw } \\
\text { publiek } \\
\text { ( } n=199)\end{array}$ & $\begin{array}{l}\text { aarheid } \\
\text { huisartsen } \\
(\mathrm{n}=70)\end{array}$ \\
\hline goed/betrouwbaar & 87 & 84 & 82 & 89 \\
\hline $\begin{array}{l}\text { tamelijk goed/ } \\
\text { betrouwbaar }\end{array}$ & 13 & 16 & 8 & 10 \\
\hline $\begin{array}{l}\text { niet goed/ } \\
\text { onbetrouwbaar }\end{array}$ & - & - & 10 & 1 \\
\hline
\end{tabular}

Op grond van deze tabel kunnen we concluderen dat de presentatie en de betrouwbaarheid van de informatie niet verantwoordelijk zijn voor het relatief grote verschil in waardering van het programma. Als mogelijke verklaring zou kunnen gelden de nieuwe informatie die in 
het programma vervat is. Voor slechts 3\% van de artsen bevatte het programma nieuwe informatie terwijl dit voor $60 \%$ van de publiek gold. Bij het publiek constateerden we het volgende gegeven: Hoe hoger de opleiding des te minder nieuwe informatie trof men aan in het programma. Bij kijkers die meer dan 2,5 uur per dag voor de buis zitten was de informatiewinst het grootst. Aan de artsen is apart gevraagd of de informatie in het programma volledig was. Ongeveer de helft van de artsen was van mening dat de informatie niet volledig was.

Het merendeel van de artsen $(84 \%)$ geeft te kennen dat zij in de spreekkamer weleens geconfronteerd worden met reacties naar aanleiding van tv-programma's. De aard van deze reacties heeft meestal betrekking op identificatie met symptomen van een ziekte (32\%), ongerustheid of angst $(21 \%)$ en nadere uitleg en meer informatie $(18 \%)$. De meerderheid van de ondervraagde artsen moet weleens corrigerend optreden naar aanleiding van reacties op de media. De volgende oorzaken van "loos alarm" worden het meest genoemd: mensen betrekken de informatie teveel op zichzelf $(50 \%)$, mensen interpreteren de informatie in negatieve zin $(51 \%)$ of men heeft uit de informatie verkeerde conclusies getrokken $(22 \%)$.

Aan de huisartsen, die direct na de uitzending geïnterviewd zijn, is de vraag voorgelegd of zij denken dat naar aanleiding van het onderhavige programma reacties te verwachten zijn op het spreekuur. Bijna $32 \%$ verwacht reacties naar aanleiding van dit programma en $62 \%$ is er van overtuigd geen reacties te ontvangen. Aan degenen die wel reacties verwachten is de vraag voorgelegd aan welk soort reactie men denkt. De meerderheid denkt aan geruststelling, herkenning van symptomen, paniekreacties en aan vragen om meer informatie.

Aan de huisartsen die een of twee dagen na de uitzending gebeld zijn (45 in totaal) is geïnformeerd naar de werkelijke reacties op het programma. Bij 5 huisartsen $(11 \%)$ zijn werkelijke reacties geregistreerd.

Ook bij het publiek is geïnformeerd of men naar aanleiding van een tv-uitzending weleens contact heeft opgenomen met een arts of andere hulpverleners. Bij $94 \%$ van de onderzochte populatie was dit nooit het geval geweest. De onderhavige uitzending had slechts een feitelijke reactie tot gevolg. Dit is niet zo verwonderlijk omdat slechts $5 \%$ van de respondenten te kennen gaf bij de problematiek van dit speciale thema (aangeboren hartafwijkingen) betrokken te zijn. Ofschoon de reacties bij de huisarts in de vorm van consultatie 
marginaal zijn, heeft eenderde van de populatie de intentie om hun gedrag te wijzigen of de adviezen op te volgen naar aanleiding van tv-programma"s. Deze intentie troffen we vooral aan bij vrouwen, respondenten tussen 30 en 50 jaar en respondenten met een lagere opleiding. Van degenen die beweren wel eens van plan zijn geweest hun gedrag of leefwijze te veranderen of aan te passen, beweerd de helft dit ook daadwerkelijk gedaan te hebben.

\subsubsection{De opinie van de huisartsen}

Aan de huisartsen is gevraagd de belangrijkste doelstelling aan te geven van een voorlichtingsprogramma via de televisie. Bevordering van de eigen verantwoordelijkheid wordt door de meeste huisartsen (74\%) als belangrijkste doelstelling aangemerkt. Beduidend minder wordt kennisvermeerdering bij het publiek als doel genoemd. Ook is geïnformeerd naar het soort onderwerpen die in een tv-programma aan de orde moeten komen. Volgens de mening van de huisartsen zouden de tv-programma's zich voornamelijk moeten richten op de omgang met alledaagse ziektes en/of kleine aandoeningen en kwalen $(56 \%)$. Voorts zou meer aandacht geschonken moeten worden aan adviezen over hoe men ziektes kan voorkomen (34\%) en aan leefwijzen. Onderwerpen die persé vermeden zouden moeten worden, zijn specialistische onderwerpen en het vertonen van medische hoogstandjes (bijvoorbeeld reageerbuisbaby's). Ook dringen artsen aan op serieuze en eerlijke voorlichting over het gebruik van alternatieve geneeswijzen. Tenslotte is aan de artsen de vraag voorgelegd of zij het belangrijk vinden dat hun patiënten naar gezondheidsprogramma's kjiken. Slechts $20 \%$ van de artsen kan het niets schelen of de patiënten naar zulke programma's kijken; 30\% van de huisartsen zegt de belangrijkheid afhankelijk te stellen van het programma(onderwerp). De helft vindt het wel belangrijk zodat de communicatie tussen hulpverlener en arts beter verloopt.

\subsubsection{De mening van het publiek}

Ongeveer de helft van de onderzochte populatie is van mening dat voldoende aandacht geschonken wordt aan gezondheid en ziekte op de televisie. Bijna $40 \%$ heeft behoefte aan meer informatie; zij willen 
meer aandacht voor dit soort onderwerpen omdat het leerzaam is en veel practisch nut heeft. De bronnen die men het liefst zou willen radplegen ten aanzien van informatie over gezondheid en ziekte en de wijze waarop men thans informatie vergaart over genoemde onderwerpen, zijn weergegeven in de tabel 9.2.

Tabel 9.2 Voorkeur en gebruik van bronnen ten aanzien informatie over gezondheid en ziekte bij publiek $(n=199)$.

\begin{tabular}{|lcc|}
\hline Bronnen & $\begin{array}{c}\text { feitelijk } \\
\text { gebruik } \\
\%\end{array}$ & voorkeur \\
$\begin{array}{l}\text { Medisch circuit } \\
\text { (arts, specialist) }\end{array}$ & 76 & 72 \\
$\begin{array}{l}\text { Media } \\
\text { (tv, radio, krant, tijdschrift) }\end{array}$ & 12 & 17 \\
$\begin{array}{l}\text { Omgeving } \\
\text { (familie, buren, vrienden) }\end{array}$ & 8 & 6 \\
$\begin{array}{l}\text { Lekencircuit } \\
\text { (patiëntenver.zelffhulpgroepen) }\end{array}$ & 2 & 3 \\
\hline
\end{tabular}

Indien we een vergelijking trekken tussen de voorkeur en het feitelijk gebruilk van informatiebronnen dan blijkt dat het merendeel van de kijkers het liefst gebruik maakt van het formele circuit dat will zeggen de arts en de specialist.

Een niet onaanzienlijk deel (17\%) heeft een duidelijke voorkeur voor "objectieve informatie" via de media. Meer dan $10 \%$ maakt er dan ook daadwerkelijk gebruik van.

Uit onderzoek van De Bock (1978) is gebleken dat de Nederlander de televisie in het algemeen als het meest betrouwbare massamedium 
aanmerkt. Wij zijn nagegaan of dit ook geldt ten aanzien van informatie over gezondheid en ziekte. Deze vraag hebben we voorgelegd aan de huisartsen en aan het publiek Onderstaande tabel laat zien dat zowel artsen als publiek de dezelfde hièrarchie aanbrengen ten aanzien van de betrouwbaarheid van de informatie.

Tabel 9.3 Vergelijking tussen publiek $(n=199)$ en huisartsen $(n=80)$ over het meest betrouwbare massamedium ten aanzien van informatie over gezondheid/ziekte (in \%).

\begin{tabular}{|lcc|}
\hline & publiek & huisartsen \\
televisie & 77 & 45 \\
krant & 3 & 8 \\
radio & 5 & 3 \\
tijdschrift & 7 & 19 \\
geen van allen/geen mening & 9 & 25 \\
chi-kwadraat $=32.35 ;$ p $<0.001$ & & \\
\end{tabular}

Weliswaar is de volgorde in voorkeur in bovenstaande tabel gelijk, maar er zijn significante verschillen tussen de twee groepen: $45 \%$ van de huisartsen vindt de TV het meest betrouwbare medium, terwijl $76 \%$ van het publiek deze mening is toegedaan. Huisartsen stellen zich nogal gereserveerd op ten aanzien van dit item: ongeveer een kwart heeft geen mening en stelt de betrouwbaarheid afhankelijk van het karakter van de specifieke media. Deze gegevens bevestigen de bevindingen uit de literatuur (Richman en Urban, 1978; Mortensen, 1982). Huisartsen staan over het algemeen sceptischer tegenover informatie via de televisie en zijn kritischer en terughoudender wat betreft uitspraken over de betrouwbaarheid van de informatie. 


\subsubsection{De voorkeur voor informatieve programma's}

Aan het publiek is gevraagd een keuze te maken uit drie soorten informatieve programma's indien deze op hetzelfde tijdstip worden uitgezonden, namelijk een actualiteitenprogramma, een programma over de natuur, kunst en literatuur en een programma over gezondheid en leefwijze. In onderstaande tabel 9.4 wordt de voorkeur voor informatieve programma's weergegeven, uitgesplitst naar de variabelen geslacht, leeftijd en opleiding.

Tabel 9.4 Voorkeur voor informatieve programma's naar geslacht, leeftijd en opleiding bij publiek $(n=199$, in \%).

\begin{tabular}{|c|c|c|c|c|}
\hline & $\begin{array}{l}\text { documen- } \\
\text { taire }\end{array}$ & $\begin{array}{l}\text { gezond- } \\
\text { heids- } \\
\text { programma }\end{array}$ & $\begin{array}{l}\text { aktuali- } \\
\text { teit }\end{array}$ & $\begin{array}{l}\text { geen } \\
\text { voorkeur }\end{array}$ \\
\hline $\begin{array}{l}\text { GESLACHT } \\
\text { man } \\
\text { vrouw }\end{array}$ & $\begin{array}{r}15 \\
8\end{array}$ & $\begin{array}{l}36 \\
63\end{array}$ & $\begin{array}{l}45 \\
25\end{array}$ & $\begin{array}{l}4 \\
4\end{array}$ \\
\hline $\begin{array}{l}\text { LEEFTIJD } \\
15-29 \\
30-49 \\
50+\end{array}$ & $\begin{array}{r}9 \\
11 \\
12\end{array}$ & $\begin{array}{l}44 \\
55 \\
51\end{array}$ & $\begin{array}{l}47 \\
30 \\
33\end{array}$ & $\begin{array}{l}- \\
5\end{array}$ \\
\hline $\begin{array}{l}\text { OPLEIDING } \\
\text { lo } \\
\text { lbo } \\
\text { mavo } \\
\text { havo/vwo }\end{array}$ & $\begin{array}{r}9 \\
5 \\
9 \\
21\end{array}$ & $\begin{array}{l}53 \\
80 \\
50 \\
27\end{array}$ & $\begin{array}{l}31 \\
12 \\
41 \\
43\end{array}$ & $\begin{array}{l}6 \\
3 \\
- \\
9\end{array}$ \\
\hline
\end{tabular}

Iets meer dan de helft van de onderzochte populatie (52\%) kiest voor gezondheidsprogramma's. Tussen mannen en vrouwen is een verschil 
in voorkeur te constateren; $46 \%$ van de mannen kiest voor een aktualiteitenrubriek en $36 \%$ voor gezondheidsprogramma's terwijl de voorkeur van vrouwen uitgaat naar gezondheidsprogramma's $(63 \%)$ en $25 \%$ naar actualiteitenrubrieken. Ook leeftijd en opleiding spelen een rol in het mediagedrag; jongeren beneden de dertig jaar kiezen voor actualiteitenrubrieken terwijl ouderen gezondheidsprogramma's prefereren $(30-49 \mathrm{jaar}=55 \% ; 50$ en ouder $=51 \%)$. Mensen met een hogere opleiding hebben een voorkeur voor actualiteitenrubrieken $(43 \%)$; in tegenstelling tot mensen met een lagere opleiding waarvan $80 \%$ kiest voor gezondheidsprogramma's.

\subsection{Slotbeschouwing}

Informatieverschaffing over gezondheid en ziekte via de massamedia mag men niet over een kam scheren. Er is een aantal journalistieke invalshoeken van waaruit men deze thema's onder de aandacht van het publiek brengt. Zo zal de medische journalist met name de nieuwswaarde van actuele gebeurtenissen voor het voetlicht halen en "human interest" benadrukken; de wetenschapsjournalist probeert de geneeskunde te vulgariseren door nadere achtergrondinformatie te verstrekken over medische ontwikkelingen. De informatie beperkt zich niet tot verslaglegging over de curatieve zorg; ook beleidsinformatie (bijvoorbeeld de reductie van het aantal bedden in een ziekenhuis) of natuurwetenschappelijke aspecten van de geneeskunst worden met een zekere regelmaat in de media aan de orde gesteld. Naast een informatieve en verstrooiende functie hebben massamedia ook een educatieve functie; deze functie kan zowel betrekking hebben op vorming (het verwerven of veranderen van opinies, interesses, attitudes etc.) als op instructie waarbij cognitieve doelstellingen (kennis, inzicht en toepassing van de informatie) domineren. Educatieve programma's over gezondheid en ziekte kunnen via het beeldscherm op twee manieren overgebracht worden namelijk het gebruik van televisie als zelfstandig medium en als onderdeel van een multimediaal pakket. Het laatstgenoemde gebruiksalternatief heeft meestal betrekking op gecommitteerde doelgroepen dat wil zeggen dat de kijker zich op enigerlei wijze verbonden heeft tot kijken, bijvoorbeeld door zich in te schrijven voor een tv-cursus.

Dit onderzoek heeft betrekking op televisieprogramma"s die bedoeld zijn voor het algemene (grote) publiek. Deze programma's zijn voor 
gezondheidsvoorlichting rellevant als ze zowel een informatieve als een educatieve functie hebben. De programma's die in Nederland op het scherm verschijnen zijn doorgaans aan te merken als informatieve programma's waarbij voornamelijk informatie verspreid wordt over de curatieve gezondheidszorg. Er zijn maar weinig programma's die het predikaat educatief kunnen dragen. Dit wil zeggen dat men op een doelbewuste wijze, middels een pedagogisch-didactische werkwijze, veranderingen probeert te bewerkstelligen in kennis, attitude of gedrag. Recentelijk heeft Heuvelman (1989) onderzocht hoe educatieve televisieprogramma's gestructureerd moeten worden om educatieve doelstellingen te realiseren. Op basis van een aantal realistische experimenten komt hij tot een aantal opmerkelijke conclusies, die voor voorlichting via de media zeer waardevol zijn. Heuvelman stelt dat bij educatieve televisie hoge eisen moeten worden gesteld aan de vormgeving van de informatie. Hij concludeert dat de in de programma's gebruikte visualisatiewijze van beslissende invloed is op de mate waarin informatie diepgaand wordt verwerkt en beklijft. Interessant is de bevinding dat wanneer het programma voldoet aan een goede audiovisuele vormgeving er op termijn geen verschillen zijn tussen hoger opgeleiden en lager opgeleiden ten aanzien van het reproduceren van kennis. Daarom zouden programmamakers meer gebruik moeten maken van schematische visualisaties waardoor een betere afstemming bereikt wordt in betekenis van beeld en tekst. Indien met een audiovisueel medium abstracte onderwerpen aan de orde worden gesteld, genieten schematische visualisaties de voorkeur boven realistische beelden. Het is bekend dat het grote publiek vooral geïnteresseerd is in onderwerpen die direct verbonden zijn met het dagelijkse leven en waarbij verwacht mag worden, dat de betreffende tv-programma's onmiddellijk bruikbare praktische informatie zullen verschaffen. Dat informatie over gezondheid en ziekte bij het publiek zo hoog staat aangeschreven, is derhalve niet verwonderlijk.

Op basis van dit onderzoek kunnen we voorzichtig concluderen dat zich de afgelopen jaren een kentering heeft afgetekend in de visie en houding van artsen ten aanzien van massamediale voorlichting. Uit onderzoek van Spronk en Warmenhoven (1982) bleek dat artsen de voorlichting via de media met een zekere mate van argwaan benaderen. Artsen verwijten de journalistiek in zekere zin sensatiezucht, vertekening van de werkelijkheid door foutieve en onvolledige verslaglegging en het scheppen verwachtingen die niet waargemaakt kunnen worden. Ook vrezen de artsen dat emotioneel geladen 
onderwerpen een inbreuk plegen op de arts/patient relatie. Dergelijke informatie zou bij de patiënten leiden tot angst, twijfel en onrust. Bij een aantal artsen blijft deze kritiek bestaan. Echter uit dit onderzoek blijkt dat de meerderheid van de ondervraagde huisartsen (94\%) van mening is dat de media ten aanzien van gezondheidsvoorlichting een positieve functie kunnen vervullen. De media werden het meest genoemd als mogelijkheid van gezondheidsvoorlichting.

Zij dringen er dan ook op aan om in gezondheidsprogramma's meer aandacht te schenken aan informatie omtrent het biologisch en fysiologisch functioneren van het eigen lichaam en aan het voorkomen van alledaagse ziekten en aandoeningen (wratten, zweetwoeten, hoofdpijn, maagklachten, winderigheid, etc.). De huisartsen zijn eensgezind in hun opvatting dat het vertonen van medisch/technologische hoogstandjes geen bijdrage levert aan gezondheidsvoorlichting. Voorts is men van mening dat het voorkomen van ziekten en het bevorderen van een gezonde leefwijze in gelijke mate op de agenda"s van gezondheidsprogramma's moeten voorkomen.

De effectiviteit van voorlichting via de massamedia is in deze studie niet het object van onderzoek geweest. Er zijn nauwelijks programma's die doelstellingen nastreven die evalueerbaar zijn. Hier stoten we op het cruciale verschil in verantwoordelijkheden tussen programmamakers en voorlichters: programmamakers worden gedreven door hoge kijk- en waarderingscijfers, terwijl het de voorlichter te doen is om veranderingen ten gunste van gezond gedrag. Of een programma daadwerkelijk tot het gewenste resultaat leidt, kan niet afgemeten worden aan kijkcijfers; zij vormen slechts een prealabele voorwaarde voor effectiviteit.

De invloed van de media wordt in vele gevallen overschat; doorgaans reikt de werking van massamedia niet veel verder dan het cognitieve niveau. $\mathrm{Zij}$ kunnen kennis vermeerderen en een bewustwordingsproces in gang zetten. Met name educatieve televisie is hiervoor geschikt vanwege de zogenaamd visuele dominantie. Het betreft hier het verschijnsel dat mensen geneigd zijn eerder op hun ogen dan op hun oren af te gaan (Heuvelman, 1989). In uitzonderlijke gevallen kunnen de media attitudes veranderen, maar in de regel bevestigen zij eerder bestaande attitudes dan dat zij deze veranderen. Van directe invloed op het gedrag is nauwelijks sprake.(zie hoofdstuk 7). Desondanks hebben de electronische massamedia voor gezondheidsvoorlichting een aantal belangrijke functies. Ten eerste bepalen de media in belangrijke mate het onderwerp van gesprek op school, kantoor en 
bedrijven. Wanneer de media bepaalde onderwerpen belangrijk gaan vinden, zullen de mediagebruikers na verloop van tijd die onderwerpen ook belangrijk gaan achten. Deze agendasetting-functie kan resulteren in beinvloeding door interpersonale netwerken of, indien de omstandigheden gunstig zijn, tot aansporing voor feitelijk handelen. De media hebben ook een bekrachtigingsfunctie (Flay, 1981); zij kunnen reeds bestaande opvattingen kanaliseren en kenniselementen beter ordenen waardoor de motivatie tot preventief gedrag toeneemt. Beide functies kunnen er toe leiden dat massamediale voorlichting overgaat in interpersonale voorlichting. Vanuit deze optiek kan men het alleen maar toejuichen dat de massamedia, zoals artsen vaak denken en beweren, ontvangers naar het spreekuur drijven. 


\section{Hoofdstuk 10 Epiloog}

10.1 Inleiding

10.2 Samenvatting

10.3 Aanbevelingen

10.4 Listen, lusten en lasten

\subsection{Inleiding}

In deze nabeschouwing worden de belangrijkste bevindingen van deze studie geplaatst in het kader van de planning van publieksgerichte interventies. We doen een poging om de wetenschappelijke kennis - mea memoria - te reflecteren op de praktijk van de massamediale voorlichting. Het uitgangspunt bij deze studie was de vraag op welke wijze de massamedia te benutten zijn voor het verwezenlijken van bepaalde sociale doelstellingen. De achtergrond van deze vraag verwijst enerzijds naar de "state of the art" met betrekking tot massamediale voorlichting en anderzijds naar een speurtocht naar mogelijkheden, empirische feiten, theoretische inzichten etc. om de effectiviteit van massamediale interventies te vergroten.

Met een groothoeklens hebben we de in dit boek behandelde problematiek in beeld gebracht. Bij tijd en wijle hebben we ingezoemd om tot een synergie van pragmatische aspecten en theoretische inzichten te komen.

In de volgende paragraaf zullen we de belangrijkste bevindingen van deze studie bondig en beknopt samenvatten. De aanbevelingen voor 
de praktijk zijn vervat in de conclusies, die voorzien worden van een nadere toelichting. Aan het eind onthullen we de titel van dit boek.

\subsection{Samenvatting}

Bij wijze van introductie hebben we het begrip voorlichting gedefinieerd als het dienstbaar maken van informatie voor een (sub)populatie om individuele en/of maatschappelijke problemen op te lossen. Voorlichting is kort en bondig "knowledge utilization"; kennisbenutting. Het gebruik van het woord "dienstbaar" is geen toevallige, maar een bewuste keuze om het belang van de ontvanger bij voorlichting te accentueren.

Het verstrekken van informatie is per definitie doelgericht; echter de intensiteit van deze doelgerichtheid kan aanmerkelijk verschillen. Ter afbakening van het terrein waarop voorlichting toepasbaar is, maken we een onderscheid in twee grondvormen van voorlichting namelijk intentionele voorlichting en faciliterende voorlichting. Bij intentionele voorlichting wil de voorlichter uitdrukkelijk veranderingen aanbrengen in kennis, attitude en gedrag. Bij faciliterende voorlichting is het aanbieden van informatie vrijblijvender in de zin dat aan de ontvanger overgelaten wordt hoe hij de informatie zal gebruiken. Faciliterende voorlichting kan dan ook gezien worden als informatie-service.

\section{Voorlichting als beleidsinstrument}

Voorlichting als beleidsinstrument kan een zinvolle functie vervullen als het gaat om het oplossen van maatschappelijke problemen. Conform de door ons gehanteerde definitie kan voorlichting het aanvaarde beleid verduidelijken, toelichten en verklaren, maar kan ook als een geintegreerd deel opgenomen worden in het beleidsinstrumentarium. In dit kader kan voorlichting - om met de woorden van Van Woerkum (1990) te spreken - ondergeschikt, nevengeschikt en bovengeschikt gebruikt worden. Voor een optimaal rendement van voorlichting in de beleidscyclus is zorgvuldige afweging van het functioneel gebruik van voorlichtingsmethoden en -technieken noodzakelijk. De complexiteit van voorlichting hebben we geillustreerd aan de hand van de problematiek van sociale dilemma's. Uit deze problematiek komt duidelijk naar voren dat voor het beïnvloeden van kennis, attitude en gedrag eerst onderzoek moet plaatsvinden om de processen, die achter opvattingen, waarden, verwachtingen, handelingen etc. 
schuilgaan, grondig te analyseren. De in beeld gebrachte problematiek brengt ook aan het licht dat voorlichting een beperkt instrument is om maatschappelijke problemen op te lossen.

\section{De fundamenten van intentionele voorlichting}

Gezondheidsvoorlichting als modaliteit van intentionele voorlichting berust op drie pijlers, namelijk 1. doelgerichtheid, 2. planmatigheid en 3. systematiek. De bifurcatie van deze fundamenten is een voorwaarde voor professionele interventies.

De systematiek behelst de basis voor de planning van de interventie en komt neer op een grondige voorbereiding middels onderzoek naar de relatie tussen het (gezondheids)probleem en gedrag en een analyse naar de determinanten van gedrag die het probleem veroorzaken. Op basis van gegevens uit de probleem- en gedragsdeterminantenanalyse kan men concluderen of een interventie zinvol is en op welke wijze de implementatie vorm moet worden gegeven. De systematiek eindigt met de vraag wat het resultaat is van de interventie(s) en welke procesmatige implicaties dit heeft voor een eventueel vervolg.

Ten aanzien van intentionele voorlichting dienen stringente eisen gesteld te worden aan het formuleren van doelstellingen. Een aantal criteria waaraan doelstellingen dienen te voldoen wordt beschreven. Essentieel is het onderscheid tussen een interventiedoel en een communicatiedoel. Een interventiedoel is gericht op de oplossing van het gesignaleerde probleem. Het interventiedoel geeft aan naar welke effecten bij een bepaalde populatie gestreefd wordt en omschrijft de verwachte resultaten in termen van verifieerbare grootheden. Het interventiedoel dient geoperationaliseerd te worden in subdoelen, die weergegeven worden in gedragstermen. Het communicatiedoel heeft betrekking op de inhoud van de boodschap en geeft aan welke handelingen van de doelpopulatie verwacht worden. Het communicatiedoel is sterk afhankelijk van het medium dat in de voorlichting gebruikt gaat worden. Een interventiedoel bevat, door de bank genomen, meerdere communicatiedoelen.

De laatste pijler van de trias van professionele voorlichting is de planmatigheid: voorlichting is een stochastisch proces dat zich in fasen voltrekt om respectievelijk te leiden tot verandering in kennis attitude en gedrag en uiteindelijk resulteert in gedragsbehoud. Niet alleen vanuit evaluatief oogpunt is een gefaseerde aanpak noodzakelijk maar meer nog uit het idee dat men tijdens het proces op 
gezette tijden adequate middelen kan inzetten om het gewenste doel te realiseren.

\section{Motivatie als aangrijpingspunt voor verandering}

Alom wordt beweerd dat voorlichting dient aan te sluiten bij de verwachtingen, kennis, behoeften, wensen, ervaringen en motivatie van het publiek. Geen enkele voorlichter zal deze bewering bestrijden. Bovengenoemde begrippen hebben gemeen dat ze verwijzen naar psychische gesteldheden of belevingen. Men zou ze ook motivationele determinanten kunnen noemen. Motivationele determinanten hebben betrekking op de aard, omvang, intensiteit en oorsprong van beweegredenen, die aan het menselijk handelen ten grondslag liggen. Middels nasporingen in de omvangrijke literatuur hebben we gepoogd het begrip motivatie te verhelderen en bruikbaar te maken voor de praktijk van de voorlichting. We komen tot de slotsom dat motivatie berust op een evaluatie van ervaringen, waarnemingen en belevingen. Bij de evaluatie worden twee parameters gehanteerd, namelijk de verwachting die iemand heeft over het (kunnen) bereiken van een bepaald doel en op de tweede plaats door de waarde die dat doel voor de persoon heeft. De uitkomstverwachtingen omtrent de effectiviteit van het opvolgen van de voorlichtingsboodschap is van cruciaal belang. We sluiten daarmee aan bij de opvattingen van Bandura die stelt dat het gedrag de resultante is van de gedragseffectiviteit in de zin van de perceptie over de uitkomst van het opvolgen van het gewenste gedrag (ben ik erbij gebaat?) en de eigen effectiviteit dat wil zeggen de perceptie omtrent de eigen mogelijkheden om het aanbevolen gedrag ten uitvoer te brengen (kan ik het?). Wil voorlichting aansluiten bij de motivatie van de doelgroep, dan is het aangrijpingspunt het cognitieve verwerkingsproces ten aanzien van de effectiviteitsverwachtingen.

\section{Het verwerven van informatie}

Het verwerven van informatie, in de $\operatorname{zin}$ van welke wegen ontvangers kunnen bewandelen om informatie te vergaren, staat centraal in hoofdstuk 4. Met name gaan we in op die factoren die bepalend zijn voor de omgang met de media. We verplaatsen ons daartoe in de positie van de ontvanger om te achterhalen welke sociale en psychologische factoren van invloed zijn op het media-gedrag. Voor het ontwikkelen van een strategie is het van belang om te weten hoe het in de boodschap gesignaleerde probleem door de ontvanger geper- 
cipieerd wordt en welke knelpunten een mogelijke verandering in de weg staan. We benadrukken dat de ontvanger benaderd dient te worden als een volwaardige (serieuze) gesprekspartner, die kritisch en rationeel de hem aangeboden informatie selecteert, interpreteert en verwerkt. In de sense-making-approach van Dervin, een variant op de "Uses and gratifications"-benadering, zijn voldoende aanknopingspunten te vinden om de positie van de ontvanger zowel persoonlijk als contextueel te postuleren. Het zoeken naar en gebruik van informatie kan het best voorspeld worden op basis van gegevens over hoe de doelpopulatie de situatie inschat, de beperkingen en verplichtingen, die ze percipiëren, het verschil tussen de oorspronkelijke en gewenste situatie en de wijze waarop ze zelf het probleem willen oplossen. Er dient meer aandacht te zijn voor situationele variabelen dan voor persoonlijke/demografische variabelen.

\section{Modellen van intentionele voorlichting}

In hoofdstuk 6 wordt een aantal courante modellen belicht, dat bruikbaar is voor de planning van intentionele voorlichting. Het informatieprocesmodel en de "communication/persuasion"-matrix van McGuire worden uitvoerig besproken en van commentaar voorzien. Het model van McGuire heeft weliswaar enigszins aan actualiteit ingeboet maar het blijft een waardevol raamwerk voor de planning van interventies. De "communication/persuasion"-matrix wordt gevoed door een breed arsenaal van sociaal-psychologische theorieën. We hebben gepoogd om de consequenties van deze theorieen door te trekken naar praktische implicaties voor de voorlichtingspraktijk. We constateren dat deze concretisering beschouwd moet worden als prealabele voorwaarde, die in de planning van interventies geïntegreerd dient te worden.

Het model van Kok is een fasenmodel dat is opgebouwd uit de eerste fasen (aandacht en begrip) van McGuire. Het model van Fishbein en Ajzen geeft in dit model de relatie weer tussen attitudeverandering en gedragsverandering. Het model van Rogers wordt benut voor de overgang van gedragsverandering naar gedragsbehoud. In het model van Kok wordt per fase aangegeven welke variabelen van belang zijn om het proces te continueren. De inzichten van Kok kunnen beschouwd worden als een welkome aanvulling op het model van McGuire vanwege het feit dat de rol van de sociale omgeving en verwachtingen ten aanzien van effectiviteit van het gewenste gedrag uitvoerig aan de orde worden gesteld. 
In het model van Petty en Cacioppo worden twee routes geïntroduceerd die tot verandering kunnen leiden. De eerste route gaat uit van de inhoud van de boodschap (centrale route); de tweede (de perifere route) benadrukt vooral de vormaspecten van het voorlichtingsbericht. In wezen komt het onderscheid neer op verandering door cognities en verandering door affecties. In het model wordt aangegeven welke factoren invloed hebben op de keuze voor de centrale, dan well perifere route. Cognitieve informatieverwerking leidt tot meer stabiele verandering, dit impliceert dat de voorlichter zorgvuldig de boodschap moet samenstellen. In laboratoriumsituaties heeft dit model de toets der kritiek kunnen doorstaan. In de praktijk van de voorlichting dient dit model nog verder uitgekristalliseerd te worden.

Het integratiemodel van Flay is tot stand gekomen door de resultaten van geëvalueerde massamediale campagnes te bundelen. In tegenstelling tot de voorafgaande modellen is dit model specifiek ontworpen voor massamediale voorlichting. Het model van Flay - als verlengstuk van een reconceptualisatie van het informatieprocesmodel - biedt naar onze overtuiging reden tot gematigd optimisme ten aanzien van de effectiviteit van massamediale voorlichting. Flay legt vooral de nadruk op persoonsfactoren (zoals eigen-effectiviteit), bekrachtiging en gedragservaring. Met name verandering via gedragservaring is in massamediale voorlichtingscampagnes vaak onderbelicht gebleven terwijl in aangrenzende werkgebieden hiermee bevredigende resultaten zijn geboekt. Aan het eind van dit hoofdstuk introduceren we twee strategieën die in voorlichtingscampagnes kunnen worden aangewend, namelijk overreding via gedragservaring en overreding via de boodschap. Wil overreding via de boodschap tot de gewenste resultaten leiden, dan moeten hoge eisen gesteld worden aan de compositie van de boodschap.

\section{Het pretesten van voorlichtingsmateriaal}

Met pretesten kan de compositie (zowel vorm als inhoud) geoptimaliseerd worden en kan worden nagegaan of de boodschap begrepen wordt en voldoet aan verwachtingen, behoeften en mogelijkheden van de doelgroep. We introduceren een testroute, die bestaat uit drie fasen. De eerste fase bevat een toetsing van de boodschap aan zowel voorlichtingskundige als aan inhoudsdeskundige criteria. Uit deze test resulteert een ruwe tekst, die herschreven en voorzien wordt van een passende lay-out en illustratie door professionele vormgevers/tekstschrijvers. De (voorlopig) originele versie wordt 
vervolgens voorgelegd aan de uiteindelijke doelgroep en daarna (met eventuele wijzigingen) ter fiattering voorgelegd aan communicatiedeskundigen en inhoudsdeskundigen. Wil men weten wat precies de bijdrage aan de interventie is geweest van het geteste voorlichtingsmateriaal dan kan men dit middels een posttest achterhalen. Afhankelijk van het onderwerp en het medium kan men een keuze maken uit een aantal methoden van pretesten, dat beknopt is beschreven.

\section{De effecten van massamediale voorlichting}

Over de invloed van de media zijn de meningen nog steeds verdeeld. De discussie over de werking van de media moet gebonden worden aan twee restricties. Op de eerste plaats dient de effectiviteit per medium (en dan ook liefst in de context waarin het gebruikt wordt) te worden vastgesteld en ten tweede dient effectiviteit bezien te worden in het licht van vooraf geformuleerde doelstellingen. We concluderen op basis van literatuur dat massamediale campagnes over het algemeen zwakke resultaten opleveren als het gaat om veranderingen in attitude en gedrag. Indien professioneel aangewend, blijken massamedia wel in staat om veranderingen in het cognitieve domein te bewerkstelligen, namelijk kennisvermeerdering en bewustwording. De Nederlandse campagnes laten ongeveer hetzelfde beeld zien als de resultaten van buitenlandse campagnes. Opmerkelijk is dat doorgaans een florissanter beeld van de resultaten wordt geschetst dan op grond van empirische gegevens kan worden vastgesteld.

\section{Preventie van skiblessures}

In het tweede gedeelte van dit boek wordt verslag gedaan van een gerandomiseerde interventiestudie naar de preventie van skiblessures. Ofschoon het aantal skiërs de laatste jaren gestaag groeit, is het aantal skiblessures sinds het einde van de jaren zestig nagenoeg gelijk gebleven. De reden voor het relatief constant blijven van het aantal blessures moet gezocht worden in de technische perfectionering van de ski-uitrusting. Desondanks blijft het aantal skiblessures betrekkelijk groot met veelal ernstige (financiële) consequenties. Op basis van uitgebreid literatuur onderzoek wordt geconcludeerd dat met name het niet of niet juist afstellen van de bindingen als voornaamste oorzaak van het optreden van blessures moet worden aangemerkt. Dit onderzoek heeft als doelstelling na te gaan op welke wijze een massamediale gezondheidseducatieve interventie kan bijdragen aan 
het voorkomen van skiletsels. De resultaten van deze studie zullen als basis dienen voor een grootschalige nationale campagne. In de gedragsdeterminantenanalyse werd geconstateerd dat het afstellen van bindingen in aanmerking komt als object van interventie. Deze constatering is gewettigd op grond van het feit dat de gewenste verandering voldoet aan criteria van relatieve belangrijkheid (er is een directe relatie tussen probleem en gedrag) en relatieve veranderbaarheid (het betreft voornamelijk een cognitief probleem, dat middels voorlichting tot een oplossing gebracht kan worden). In deze interventiestudie worden een drietal variabelen in elk twee condities gemanipuleerd om te bezien op welke wijze de campagne het beste gerealiseerd kan worden, namelijk a. medium (folder versus audiocassette), b. het tijdstip van distributie van het voorlichtingsmateriaal, en c. de benaderingswijze, namelijk het gebruik van al dan niet angstaanjagende voorlichting waarin de ernst en de kwetsbaarheid voor de persoon beklemtoond wordt.

Voorlichtingsmateriaal met angst heeft in deze interventie de meeste invloed gehad op het afstelgedrag, ongeacht het tijdstip en het medium. Onze bevindingen sluiten nauw aan bij de recente literatuur over angstaanjagende voorlichting. Angstaanjagende voorlichting is alleen gepermitteerd indien de reacties van mensen ertoe leiden dat men zelf het probleem kan oplossen en als empirisch is aangetoond dat het opvolgen van de boodschap inderdaad effectief is. Mensen, die bang gemaakt worden zonder dat er een effectief middel is, die de angst kan minimaliseren, reageren averechts. Wat betreft het medium (folder versus cassette) kunnen we concluderen dat de cassette hoger scoort dan de folder inzake aandacht en agendasetting. Naar ons idee is het verrassingseffect (i.c. het feit dat het nog geen gemeengoed is om cassettes te verspreiden) hier debet aan. Nader onderzoek is gewenst naar de effectiviteit van auditief voorlichtingsmateriaal. Dit geldt nog in sterkere mate voor het tijdstip waarop de voorlichtingsboodschap gedistribueerd moet worden. In deze studie zijn we er niet in geslaagd om kracht bij te zetten aan het vermoeden dat de mate van ontvankelijkheid voor de voorlichtingsboodschap van cruciale betekenis is. De folder als voorlichtingsmedium blijft uit oogpunt van kosten en praktische uitvoerbaarheid favoriet.

\section{Patiëntenvoorlichting via de massamedia}

Tot slot wordt verslag gedaan van een onderzoek naar reacties van het publiek en huisartsen op een uitzending van het tv-programma 
"Vinger aan de Pols". Aanleiding voor het onderzoek was (de ontmaskering van) het idee dat na een tv-uitzending over gezondheid en ziekte de wachtkamers van huisartsen volstromen met angstige, ongeruste en paniekerige patiënten. Huisartsen geven herhaaldelijk te kennen dan men niet altijd even gelukkig is met deze onverwachte toeloop. In dit onderzoek worden drie vragen beantwoord, namelijk wat de mening van de huisarts is over voorlichting via de massamedia, in welke mate het consultatiegedrag beinvloed wordt door programma's over gezondheid en ziekte, en wat de opinie van het publiek is over deze programma's. Geconcludeerd wordt dat de meerderheid van de ondervraagde huisartsen van mening is dat de media ten aanzien van gezondheidsvoorlichting een positieve functie vervullen. De artsen zijn evenwel van mening dat in deze programma's meer aandacht geschonken moet worden aan het biologisch en fysiologisch functioneren van het menselijk lichaam en aan het voorkomen van alledaagse ziekten en kleine kwalen. Ongeveer de helit van het publiek is tevreden met het huidige aanbod op dit gebied; $40 \%$ heeft behoefte aan meer informatie omdat deze programma's leerzaam zijn en veel praktisch nut hebben. De onmiddellijke effecten van een tv-uitzending op het consultatiegedrag zijn - in deze studie - gering. Wel wordt op het spreekuur regelmatig gesproken over onderwerpen, die in de media aan de orde zijn gesteld. Het betreft hier evenwel geen paniekreacties (angst, twijfel, ongerustheid) maar veelal vragen om nadere toelichting of uitleg over zaken die recentelijk in de media aan bod zijn geweest.

\subsection{Aanbevelingen}

In het voorafgaande hebben we gepoogd om een aantal facetten van massamediale voorlichting in beeld te brengen. Dat beeld is bij lange na niet volledig. De demarcatielijn hebben we getrokken bij die aspecten die van belang zijn voor de planning van interventies. Een nadere afbakening betreft die massamediale interventies waarbij de voorlichter opzettelijk tracht veranderingen te bewerkstelligen bij het publiek ten aanzien van cognities, attituden en gedrag.

Bij herhaling hebben we laten doorschemeren dat de "omnipotentie" van de massamedia in het kader van intentionele voorlichting erg mager is: nauwelijks veranderingen in gedrag en subtiele verandering in attituden. Krachtiger zijn de media als het gaat om bewustwording, 
kennisvermeerdering en het bevestigen van bestaande attituden en opvattingen. In sommige gevallen kunnen we verklaren waarom massamediale voorlichting wel effectief is en in andere gevallen niet. Voor onderzoekers ligt hier nog een groot terrein braak. Ondanks de relatief zwakke resultaten van massamediale voorlichting blijven we optimistisch inzake de mogelijkheden om de effectiviteit op te schroeven. In het navolgende zullen we enkele aanbevelingen doen die serieuze aandacht verdienen bij de planning van interventies.

\section{Functioneel gebruik van de media en participatie van intermediaire kaders:}

Het arsenaal aan middelen dat de voorlichter ter beschikking staat is betrekkelijk groot. In de praktijk wordt vaak grof geschut ingezet omdat men denkt dat daarmee het merendeel van de schootsmassa geraakt wordt. Meestal is dat ook zo, maar dat geeft nog geen enkele waarborg dat de ontvanger conform de intentie van de zender gaat denken of handelen. Bij de inzet van de massamedia wordt vaak over het hoofd gezien dat er sprake is van eenrichtingverkeer van zender naar ontvanger. De mogelijkheden voor feedback ontbreken waardoor de ontvanger nagenoeg geen kansen krijgt om in de interventie te participeren. Uit succesvolle campagnes blijkt dat participatie een bevorderende factor is in het welslagen van een campagne. Bij massamediale campagnes is het zaak om zorgvuldig af te wegen welke media men gaat gebruiken en hoe deze op elkaar afgestemd kunnen worden. Belangrijk daarbij is om te letten op het functioneel gebruik en het communicatievermogen van de verschillende media. Een boodschap op een bierviltje heeft wellicht een hoge attentiewaarde maar men kan er geen uitgebreide verhalen op kwijt. Het functioneel gebruik van het medium dient gerelateerd te worden aan het mediagedrag van de doelpopulatie. Voorts dient men te bedenken hoe mensen het gebruik van het medium percipiëren, (bijvoorbeeld hoe betrouwbaar/geloofwaardig) is het medium. Een ander aspect van het functioneel gebruik is bijvoorbeeld de visuele dominantie: mensen hechten meer waarde aan wat ze zelf zien dan wat ze van anderen horen. Nagenoeg ieder medium heeft zijn zwakke en sterke kanten. Van televisie-boodschappen is bijvoorbeeld bekend dat ze er in slagen om een informatiezoekproces in gang te zetten, terwijl de radio veelal gebruikt wordt om achtergrondinformatie te verstrekken. Het verdient aanbeveling om multimediaal te werk te gaan maar in dat geval dienen de verschillende media goed op elkaar afgestemd te worden. 
In onze opvatting is multimediaal niet beperkt tot het aanwenden van audiovisuele hulpmiddelen; met kan ook denken aan de complementaire rol die bestaande organisaties, instituties en intermediaire kaders kunnen vervullen in de vorm van ondersteuning.

Het formuleren van realistische doelstellingen en zorgvuldige compositie van de boodschap

Het formuleren van doelstellingen, de compositie van de boodschap en het segmenteren van doelgroepen rekent men tot de basistaken van de voorlichter. In de praktijk blijken deze taken toch veel moeilijkheden op te leveren. Doelstellingen - zowel op het niveau van de interventie als op het niveau van de boodschap - zijn veelal onrealistisch, te abstract en in tijd te afstandelijk. We hebben in dit boek een aantal criteria geformuleerd waaraan doelstellingen minimaal dienen te voldoen. In een boodschap dient de relatie tussen het probleem en het gewenste gedrag duidelijk aangegeven te worden. De boodschap wint aan kwaliteit als het gewenste gedrag in een utilitaire context wordt geplaatst. De boodschap dient aannemelijk te maken dat aan de uitvoering van het gewenste gedrag gratificaties verbonden zijn of dat het nalaten negatieve consequenties met zich mee kan brengen. Van de boodschap dient een motiverende werking uit te gaan. In concreto betekent dit dat men dient te anticiperen op de gepercipieerde gevolgen voor de ontvanger. De voorlichter dient derhalve aan te geven op welke wijze mogelijke barrières beslecht kunnen worden en welke vaardigheden men daarvoor behoeft. Op deze wijze verhoogt men het zelfvertrouwen van de ontvanger om zelfstandig bepaalde doelen te verwezenlijken. Nogmaals willen we beklemtonen dat de inhoud van de boodschap ook werkelijk leidt tot de oplossing van het probleem dat aan de orde is gesteld. Indien het voorlichtingsadvies niet effectief is, vervalt iedere grond om te beinvloeden.

Segmentatie van doelgroepen en ontvankelijkheid voor de boodschap

De effectiviteit van voorlichting wordt twijfelachtig als de boodschap het publiek niet op het juiste tijdstip en op de juiste plaats bereikt. Dit impliceert dat de voorlichter zich moet vergewissen van wanneer de doelgroep ontvankelijk is voor de informatie.

Het gebruik van massamedia wordt vaak gelegitimeerd door het idee dat een grote hoeveelheid mensen tegelijkertijd bereikt wordt. Derhalve vindt men dat een nadere segmentatie van de doelgroep 
achterwege kan blijwen. Het moet gezegd worden dat degene, die het bereik als maatstaf voor succes hanteren, niet in het ongelijk gesteld kunnen worden. Hanteert men echter criteria die aangeven welke veranderingen hebben plaatsgevonden, dan is het zaak om bij de keuze van het medium rekening te houden met de homogeniteit van de doelpopulatie. Bij het streven naar homogeniteit dient men onderscheid te maken tussen homogeniteit op grond van een bepaald gemeenschappelijk probleem en homogeniteit op grond van een communicatieve uitgangssitulatie.

\section{Aandacht voor de sociale context van de ontvanger}

In onze opvatting over intentionele voorlichting hebben we als uitgangspunt de "Uses and gratifications"-benadering gekozen. Deze benadering gaat ervan uit dat de ontvanger gemotiveerd de hem aangeboden informatie selecteert, interpreteert en verwerkt. In deze opvatting wordt media-gebruik bepaalt door de gratificaties die eraan verbonden zijn. De oorspronkelijke "Uses and gratifications"-benadering is in de loop der tijd niet van kritiek verschoond gebleven. Als belangrijkste tegenwerping geldt dat deze benadering onvoldoende rekening houdt met de interrelaties van samenleving, media en publiek. De "sense-making approach" is te beschouwen als een verbeterde versie van de oorspronkelijke "Uses and gratifications"benadering en stelt niet alleen het individu centraal, maar benaderd het individu vanuit zijn sociale context. Naar onze mening is voorlichting gedoemd te mislukken als het individu als object van verandering wordt gekozen zonder daarbij sociale, economische, culturele en omgevingsvariabelen bij te betrekken.

Van essentieel belang is de invloed vanuit de sociale omgeving, die zowel een positieve als een negatieve druk kan uitoefenen. De meeste massamediale interventies houden onvoldoende rekening met de sociale context van het individu; het is dan ook niet verwonderlijk dat bekrachtiging en ondersteuning uitblijft. Dit is de reden om een lans te breken om bij massamediale voorlichting niet uitsluitend de aandacht te richten op een bepaalde doelgroep, maar het schootsveld uit te breiden tot die groepen waarvan mag worden aangenomen dat ze een versterkend effect teweeg brengen. Indien blijkt dat van bepaalde (sub)populaties een negatieve invloed uitgaat, kan men deze trachten te elimineren. Als tweede doelgroep zou men ook kunnen kiezen voor intermediaire kaders (organisaties en/of instituties). $\mathrm{Zij}$ kunnen zich moeilijker aan de openbaarheid onttrekken, voelen zich meer aan- 
gesproken en ondervinden druk vanuit de achterban. Op de valreep nog een enkele opmerking over de positie van de ontvanger in het licht van het gebruik van nieuwe communicatietechnologie. Het is te verwachten dat in de toekomst het mediagebruik sterk aan verandering onderhevig zal zijn: nieuwe communicatietechnologieën (glasvezelkabels, satellieten, computers en digitale informatieverwerking) zullen de toegankelijkheid en beschikbaarheid van communicatiemedia drastisch veranderen. Met name interactieve media kunnen voor intentionele voorlichting belangrijke hulpmiddelen zijn indien de, reeds bestaande, voordelen verder worden uitgebreid (op maat gesneden informatie, tijdwinst, gebruiksvriendelijkheid, etc.).

\section{Onderzoek als basis voor massamediale interventies}

Weinigen zullen het nut van een grondige voorbereiding van een massamediale interventie betwijfelen. Dat tot een grondige voorbereiding ook onderzoek gerekend wordt, is minder vanzelfsprekend. Als standaardnorm voor iedere massamediale campagne hanteren we een probleemanalyse en een gedragsdeterminantenonderzoek. Men dient namelijk te weten welke en wiens gedragingen in het geding zijn en of er een relatie tussen gedrag en probleem bestaat. Gegevens over psychosociale, economische, motivationele en omgevingsdeterminanten vormen de basis voor iedere interventie. Vele campagnes komen meestal onder hoge tijdsdruk tot stand; dit betekent dat men "vanuit de losse pols" aan de slag gaat zonder dat men zich vergewist of de voorlichting leidt tot de oplossing van het probleem. Het komt in dit land voor dat men eerst de media kiest en vervolgens gaat nadenken wat de doelstelling van de interventie eigenlijk zou moeten behelzen. Kortom mensen worden nodeloos naar het postkantoor of bibliotheek gejaagd of worden lastig gevallen met - in ettelijke duizendvouden gedrukte - folders. Folders over de invoering van de maximum snelheid op autowegen en de nieuwe munt van vijf gulden zijn hier voorbeeiden van. Dergelijke activiteiten zouden niet met het predikaat voorlichting mogen worden aangeduid.

\section{De noodzakelijkheid van pretesten en evaluatie-onderzoek}

Naast het voorbereidende onderzoek waartoe we ook het pretestonderzoek rekenen, dient de gehele interventie vergezeld te worden door evaluatie-onderzoek. Het spreekt voor zich dat dit evaluatieonderzoek aan hoge methodologische eisen dient te voldoen. Evaluatie-onderzoek levert niet alleen inzicht in de effecten en processen van 
de interventie, maar kan ook als sturingsmechanisme aangewend worden. Gezien het feit dat men gedurende een massamediale interventie nauwelijks vat heeft op interveniërende (storende) variabelen, zouden we een pleidooi willen houden om de evaluatie te koppelen aan de belangrijkste fasen, die men in het voorlichtingsproces moet doorlopen. Deze tussentijdse evaluatie zou bijvoorbeeld kunnen plaatsvinden in de fase van oriëntatie (aandacht en begrip), tijdens de acceptatiefase (attitudeverandering) en in de fase van integratie (gedragsverandering). Het verzamelen van gegevens per hoofdfase biedt het voordeel dat een herbezinning op de te gebruiken methoden en middelen kan plaatsvinden. Voorts biedt dit mogelijkheden om de doelstelling en de daaruit voortvloeiende strategie voor het verdere verloop van het voorlichtingsproces aan te passen. Bovendien kan men er baat bij hebben als men de gegevens als feedback terugkoppelt naar de doelpopulatie.

\section{Compilatie van onderzoek en praktijk}

Qua professie gaat onderzoek en praktijk niet hand in hand. Onderzoekers behoren op de hoogte te zijn van de huidige stand van de wetenschap en moeten in staat worden geacht om degelijk onderzoek af te leveren. Zij hebben doorgaans weinig kennis of realiteitsbesef van wat in de praktijk haalbaar en uitvoerbaar is. Een bondgenootschap tussen onderzoekers en voorlichters in de zin van het complementeren van deskundigheid, komt de effectiviteit en de efficiency ten goede. Toch willen we nog wijzen op een addertje onder het gras om te voorkomen dat men denkt dat samenwerking tussen praktijk en onderzoek als een deus ex machina beschouwd kan worden. Er zijn namelijk goede programma's die slecht geëvalueerd worden, maar er zijn ook slechte programma's die ogenschijnlijk - methodologisch verantwoorde - goede resultaten laten zien. Wie gelooft dat wetenschappelijk onderzoek onfeilbaar is, gelooft in sprookjes. Duidelijk zal zijn dat naast deskundigheid op het gebied van voorlichting en onderzoek het welslagen van een interventie gebaat is bij een gezonde portie creativiteit.

\section{Voorlichting als beleidsinstrument}

Met beleid probeert men het staatsbestel te ordenen, men kan beleid opvatten als een mechanisme om richting te geven aan bepaalde politieke opvattingen. Werd voorheen voorlichting voornamelijk gebruikt om beleid bekend te maken of te propageren, vandaag de 
dag wordt de instrumentele functie van voorlichting steeds meer benadrukt. Voorlichting als beleidsinstrument kan ondergeschikt, nevengeschikt en ondergeschikt worden gebruikt. Voorlichting in combinatie met andere beleidsinstrumenten kan synergetische effecten sorteren. Voorwaarde is wel dat voorlichting dan integraal verankerd wordt in beleid. Dit impliceert dat voorlichters in een vroegtijdig stadium bij de beleidsvoorbereiding worden betrokken en de gehele beleidscyclus op de voet volgen. $\mathrm{Z}_{\mathrm{ij}}$ dienen er nauwlettend op toe te zien wanneer en hoe voorlichting kan worden ingezet. Voorlichters zijn meedenkers in de totstandkoming van beleid.

Steeds meer dringt het besef door dat voorlichtingsstrategieèn intersectoraal geimplementeerd moeten worden, d.w.z. dat alle relevante sectoren een bijdrage leveren aan de geformuleerde doelstellingen. Een intersectorale benadering veronderstelt een helder beleid, een hechte samenwerking, delegatie van verantwoordelijkheden en een strikte afbakening in taken. Intersectoraal behoeft geenszins voorbehouden te blijven aan ambtelijke en bestuurlijke kaders. Samenwerking met het bedrijfsleven is onontbeerlijk in een intersectorale aanpak.

Voorlichting op departementaal, provinciaal en gemeentelijk niveau is voor verbetering vatbaar. De miljoenen die daaraan besteed worden, kunnen effectiever worden benut. Het is onterecht om met een beschuldigende vinger te wijzen naar voorlichters op het uitvoerend vlak; de schoen wringt met name bij beleidsverantwoordelijken. Door de bank genomen hebben zij onrealistische verwachtingen ten aanzien van de effectiviteit van voorlichting en hanteren voorlichting min of meer als "strategie van de onmacht" (baat het niet, dan schaadt het niet!). Het is wenselijk dat beleidsverantwoordelijken hun beslissingen ten aanzien van voorlichting beter afstemmen op het advies van professionele voorlichters. Daarnaast zou een bijscholing in de meest elementaire voorlichtingskundige principes geen overbodige luxe zijn.

\section{Integratie van massamediale en interpersonale voorlichting}

Massamedia, mits professioneel aangewend, kunnen kennis vermeerderen en in sommige gevallen mensen activeren. Soms slaagt men erin subtiele veranderingen aan te brengen in attituden. Voor veranderingen van gedrag zijn ze nauwelijks geschikt. Uit onderzoek blijkt echter dat mensen de meeste kennis en de eerste kennis door de massamedia aangereikt krijgen. Dit gegeven dienen voorlichters optimaal te benutten door ervoor te zorgen dat deze massamediale 
informatie getransformeerd wordt naar interpersonale communicatie. Interpersonale communicatie biedt meer mogelijkheden (directe feedback, instructie, training van vaardigheden etc.) voor beïnloeding in de gewenste richting. Indien er zich veranderingen voltrekken, kunnen de massamedia aangewend worden ter bekrachtiging zodat uiteindelijk gedragsbehoud gerealiseerd wordt. Intentionele voorlichting heeft de meeste kans van slagen als massamediale en interpersonale voorlichting complementaire rollen vervullen.

\subsection{Listen, lusten en lasten}

Tot slot nog een korte toelichting op de titel van dit boek. Deze berust geenszins op boert en jokkernij. Het moge duidelijk zijn dat het bewerkstelligen van veranderingen bij het publiek via de massamedia een zeer complexe aangelegenheid is. De voorlichter kan optimaal rendement uit zijn inspanningen putten als hij zich voldoende rekenschap geeft van die factoren, die het verwerven en verwerken van voorlichting bepalen. In de eerste plaats zijn dat de listen, lusten en lasten aan ontvangersżjje maar bovenal zal hij over voldoende vernuft, energie en tolerantie moeten beschikken om zijn doel te realiseren. Een goed begin heeft een goed behagen maar het einde zal de lasten dragen. 


\section{Summary}

By way of introduction we defined the term 'communication' as making information instrumental for a (sub)population to solve individual and/or social problems. In short, communication is 'knowledge utilization'. The use of the word 'instrumental' is not fortuitous but a deliberate choice to emphasize the importance of the recipient of information in the communication process.

Giving information is by definition purposive; however, the intensity of the purposiveness can vary considerably. To limit the field in which communication can be applied, we have distinguished two basic forms of communication, namely intentional and facilitating communication. In intentional communication the communicator explicitly desires to provoke changes in knowledge, attitude and behaviour. In facilitating communication the information offered is noncommittal in that the recipient is free to choose how he or she will make use of it. Facilitating communication, therefore, can be seen as information service.

As a policy instrument communication can play a useful role in solving social problems. In accordance with the definition we are using here, communication can help to clarify, amplify and explain the implemented policy. But communication can also constitute an integral part of a set of policy instruments, as such to be applied - in the words of Van Woerkum - either subordinately, coordinately or dominantly. In order for communication to achieve maximum effect in the policy cycle, conscious consideration of the functional use of communication methods and techniques is necessary. We have illustrated the complexity of communication by means of social dilemmas, showing that prior to influencing knowledge, attitude and behaviour, research is needed to analyse thoroughly the processes 
that are hidden behind opinions, values, expectations, actions, etcetera. The problems described reveal that communication has only limited success as an instrument for solving social problems.

As a modality of intentional communication, health education is based on three pillars, namely purpose, system and method. Separating these foundations is a prerequisite in professional interventions.

System constitutes the basis of the intervention planning, which comes down to a thorough preparation by means of research into the relation between (health) problem and behaviour and analysis of the determinants of the behaviour that is responsible for the problem. On the basis of facts derived from analyses of problem and behavioural determinants, a decision can be made on the usefulness of an intervention and on the form in which implementation should take place. System ends with the questions: what are the results of the intervention(s) and what are its procedural implications regarding possible continuation?

With respect to intentional communication the formulation of the objectives should meet high standards. We have given a description of a number of criteria the objectives have to meet. It is essential to distinguish an intervention goal from a communication goal.

An intervention goal is aimed at solving the observed problem. It indicates which effects are aimed at in a particular population and it describes the expected results in terms of verifiable quantities. The intervention goal should be operationalized in sub-goals conveyed in terms of behaviour.

A communication goal involves the content of the message and indicates which actions are expected from the target group. It is heavily dependent on the medium that will be used in the communication process. By and large, an intervention goal consists of several communication goals.

The last pillar of the triad of professional communication is the method: communication is a stochastic process that takes place in phases leading to changes in knowledge, attitude and behaviour, and finally amounting to behaviour retention. A phased approach is necessary not only from an evaluative point of view, but also, importantly, in view of the idea that it will regularly enable the introduction of adequate means to realize the desired goal.

It is generally said that communication should fit the expectations, knowledge, needs, wishes, experiences and motives of the public. 
There is not a single communicator who will contradict this statement. The concepts have in common that they all refer to psychic conditions or experiences. They can also be called motivational determinants. Motivational determinants refer to the nature, scope, intensity and origin of the motives that constitute the basis of human action. By means of a survey of the extensive literature we have tried to clarify and instrumentalize the motive concept for the practice of communication. We have come to the conclusion that motive is based on evaluation of experiences, observations and perceptions. In evaluating, two parameters are applied, namely first the individual expectation of achieving (or being able to achieve) a particular goal, and second the value of this for the individual. The expectations concerning the effectiveness of compliance with the communication message are of crucial importance. This is also the opinion of Bandura, who states that behaviour is the upshot of behaviour effectiveness in terms of the perception of the outcomes of compliance with the desired behaviour (does it benefit me?) and the individual effectiveness namely the perception of one's own possibilities to perform the suggested behaviour (am I able to do it?). If communication has to fit the motives of the target group, the cognitive coping process concerning effectiveness expectations should be the starting point. Acquiring information in the sense of what recipients can do to acquire information is the central issue in chapter 4. In particular the factors that determine the media approach are dealt with. We have put ourselves in the recipient's position in order to find out which social and psychological factors influence his media behaviour.

In order to design a strategy it is important to know how the problem mentioned in the message is perceived by the recipient and which bottlenecks might hamper a possible change. We wish to emphasize that the recipient should be approached as a full (serious) communication partner, who selects, interprets and handles the information offered critically and rationally. In the 'sense making' approach of Dervin, a variation on the 'uses and gratifications approach', sufficient starting points can be found to postulate the position of the receiver personally as well as contextually.

In chapter 6 a number of recent models are described, which are useful in planning intentional communication. The information process model and the communication/persuasion matrix of McGuire are discussed and commented on in detail. Although McGuire's model has lost some topical value, it still constitutes a useful framework for 
the planning of interventions. The communication/persuasion matrix is based on a wide range of social psychological theories. We have tried to extend the consequences of these theories to practical implications of communication. We observe that such realization should be seen as given conditions, which have to be integrated in the planning of interventions.

Kok's model is a phased model constructed from the first stages (attention and understanding) of McGuire. Fishbein's model represents in this model the relation between attitude change and behavioural change. Rogers' model is used in the transition from change of behaviour to retention of behaviour. Kok's model indicates for every phase the variables that are important for continuation of the process. The insights obtained by Kok can be considered as a useful contribution to McGuire"s model, because Kok discusses in detail the role of the social environment and the expectations concerning effectiveness and the desired behaviour. Petty and Cacioppo's model introduces two routes that can lead to persuasion. The first (central) route consists of changes due to the content of the message, whereas changes following the second (peripheral) route are initiated by mere form aspects of the persuasive message. Basically, the difference comes down to cognitive change and affective change. The model locates the factors that influence the choice of either the central or the peripheral route. Cognitive elaboration leads to a more persistent change, requiring from the communicator a careful composition of the message. In laboratory situations the model has withstood the test of criticism, but in communication practice the model needs more refinement.

Flay's integration model is based on a compilation of the results of evaluated mass media campaigns. Unlike the preceding models, this model is specifically designed for mass media communication. In our opinion, Flay's model - an extension of a reconceptualization of the information-processing model - gives ground for moderate optimism with respect to the effectiveness of mass media communication. In particular, Flay emphasizes the individual factors (such as personal effectiveness), reinforcement and behavioural experience. Mass media campaigns have often paid too little attention to behaviour-based persuasion in particular, although it has yielded satisfactory results in adjacent working fields.

At the end of this chapter we have introduced two strategies that can be applied in communication campaigns, namely behaviour-based 
persuasion and message-based persuasion. For message-based persuasion to be successfull, the composition of the message should meet high requirements. Pretesting can optimize the composition (form as well as content) and can detect whether the message is understood and complies with the expectations, needs and possibilities of the target group.

We have introduced a test route, consisting of three phases. In the first phase the message is tested against communication criteria as well as content expert criteria. This results in a draft text that has to be rewritten, laid out and illustrated by professional copywriters and designers. Subsequently, the (provisional) original version is submitted to the eventual target group and adjustments are made if necessary. Then the experts have to give their approval. A post test can be considered when exact assessment of the contribution of the pretested communication material to the intervention is desired. A brief description is given of a number of pretesting methods of which the application depends on the subject and the medium used.

Opinions on the influence of the media are still divided. Discussion on the working of the media should be restricted to two factors, namely that:

a. effectiveness should be defined per medium (and preferably in the context in which it is used);

b. effectiveness should be seen in the light of the previously formulated objectives.

On the basis of literature we have concluded that mass media campaigns in general yield poor results where changes of attitude and behaviour are concerned. When professionally applied, mass media proves able to effectuate cognitive changes, namely increase of knowledge and awareness. The Dutch campaigns show more or less the same results. It is remarkable that in general a more flourishing picture is presented than empirical data reveal.

The second part of this book deals with a randomized intervention study of prevention of ski injuries. Although in recent years the number of skiers has increased steadily, the number of ski injuries has remained nearly the same since the end of the sixties. The reason for this relatively consistent figure can be found in the technical 
improvement of skiing materials. Nevertheless, the number of ski injuries is relatively large and implies considerable serious (financial) consequences. On the basis of an extensive literature survey, we have drawn the conclusion that particularly incorrect adjustment of the bindings, or failure to adjust these, can be considered as the main cause of the occurrence of injuries. The objective of this study was to find out in which way health educational interventions by means of mass media can contribute to the prevention of ski injuries. The results of the study will constitute the basis for a large scale national campaign in the Netherlands. In analysing the behaviour determinants the adjustment of the bindings was established as object of intervention. This is legitimate as the desired change complies with criteria of relative importance (there is a direct relation between problem and behaviour) and relative changeability (it constitutes mainly a cognition problem that can be solved by means of information). In the intervention study three conditions were employed to determine the way in which the campaign could best be realized. These conditions are:

a. the medium (leaflet versus audio-cassette),

b. the moment of distribution of the communication materials, and

c. the approach (fear-arousing texts - in which the severity and the vulnerability of the individual are emphasized - versus neutral texts).

Fear arousing communication material appeared to have the greatest influence on the behaviour concerning the adjustment of bindings, irrespective of the moment and the medium. As for the medium we can conclude that the cassette had a higher impact than the leaflet where attention and intention (?) are concerned. In our opinion this is due to the surprise aspect. As a communication medium, the leaflet remains the favourite in view of costs and practical feasibility.

The final part (?) of the book discusses an investigation into the reactions of the public and general practitioners to a particular television programme on health issues ("Vinger aan de pols"). The reason for this study was (the exposure of) the idea that after broadcasting such health programmes, the waiting rooms of general practitioners are filled with anxious, worried and panicky patients. Frequently, general practitioners let it be known that they are not very happy with the unexpected response (flood of patients). The three 
main questions investigated the opinion of the general practitioner about the medical information through mass media, the extent to which consultation behaviour is influenced by programmes on health and disease issues, and the opinion of the public on these programmes. Our conclusion is that the majority of the participating GPs think that the media have a positive function with respect to health education. Nonetheless, the physicians think that these programmes should pay more attention to the biological and physiological functioning of the human body and to the prevention of common small diseases and complaints. On average, half of the public are satisfied with the current supply of information in this field; 40 per cent feel the need for more information as the programmes are educational, practical and useful. The immediate effects of a television broadcast on the consultation behaviour are few, although during the consultation hours the subjects of the such programmes are frequently discussed. However, it is not a matter of panic, fear, doubt or anxiety, but more a question of asking for some explanation. 



\section{Literatuur}

Abelson, R.P., Aronson, E., en McGuire, W.J. (1968). Theories of cognitive consistency. Chicago: Rand MeNally.

Abrams, D.B., en Follick, M.J. (1983). Behavioral weight-loss intervention at the worksite: Feasibility and maintenance. Joumal of Consulting and Clinical Psychology, 51, 226-233.

Adler, R.P., Lesser, G.S., Meringoff, L.K, Robertson, T.S., en Ward, S. (1980). The effects of television advertising on children. Lexington, MA: Heath.

Adorno, Th.W. (1976). Television and the pattern of mass culture. In $\mathrm{H}$. Newcomb (Ed.), Television, the critical view. New York

Ajzen, I. (1987). Attitudes, traits and actions: Dispositional prediction of behaviour in personality and social psychology. Advances in experimental social psychology, 20, 1-63.

Ajzen, I., en Fishbein, M. (1977). Attitude-behavior relation: A theoretical analysis and review of empirical research. Psychological Bulletin, 84, 888918.

Ajzen, I., en Fishbein, M. (1980). Understanding attitudes and predicting social behavior. Englewood Cliffs, NJ: Prentice Hall.

Albion, M.S. (1983). Advertising's hidden effects: Manufacturer's advertising and retail pricing. Dedham, MA: Auburn House.

Alcala, R. (1983). The impact of mass communication campaigns in the health field. Social Science and Medicine, 17, 87-94.

Allport, G.W. (1935). Attitudes. In C. Murchison (Ed.), A handbook of social psychology. Worcester, MA: Clark University Press.

Anderson, R.C. (1980). The psychology of uritten communication. Kogan Page.

Anderson, D.M., Meissner, H.I., en Portnoy, B. (1989). Media-use and the health information acquisition process: How callers learned about the $\mathrm{NCl}$ 'S cancer information center. Health Education Research, 4, 419-427. 
Antonovsky, A, en Kats, R (1970). The model dental patient: An empirical study of preventive health behavior. Social Science and Medicine, 4, 367380.

Assema, P.T. van, en Damoiseaux, V. (1987). Diffusie en kognitieve effecten van een publiekswoorlichtingsbrochure over kanker. GVO-cahier no. 14, Maastricht: Rijksuniversiteit Limburg.

Atkin, CK (1972). Anticipated communication and mass media information seeking. Public Opinion Quarterly, 36, 188-199.

Atkin, C.K (1973). Instrumental utilities and information seeking. In P. Clarke (Ed.), New models for Mass Communication. London: Sage.

Atkin, C.K (1979). Research evidence on mass mediated health communication campaigns. In Communication Yearbook 3. New Brunswick, NJ: Transaction Books.

Atkin, C.K (1981). Mass media information campaign effectiveness. In R.E. Rice, en W.J. Paisley (Eds.), Public Communication Campaigns. Beverly Hills, CA: Sage.

Atkin, C.K (1981). Mass communication research principles for health education. In M. Meyer (Ed.), Health Education by Television and Radio. Munchen: Saur.

Atkinson, J.W. (1964). An introduction to mativation. Princeton, NJ: Van Nostrand.

Atkinson, J.W., en Feather, N.T. (Eds.). (1966). A theory of achievement motivation. New York: Wiley.

Ball-Rokeach, S.J., en Fleur, M.L. de (1976). A dependency model of mass media effects. Communication Research, 3, 3-21.

Ban, A.W. van den, (1985). Inleiding tot de voorlichtingskutde. Meppel: Boom.

Bandura, A. (1977). Social learming theory. Englewood Cliffs, N]: Prentice Hall.

Bandura, A. (1977). Self-efficacy: Toward an unifying theory of behavioral change. Psychological Review, 84, 191-215.

Bandura, A. (1978). The self system in reciprocal determinism. Americant Psychologist, 33, 344-358.

Bandura, A. (1982). Self-efficacy mechanisms in human agency. American Psychologist, 37, 122-147.

Bandura, A. (1986). Social foundations of thought and action. Englewood Cliffs, N]: Prentice Hall.

Becker, L.B., en Whitney, D.C. (1980). Effects of media dependencies: Audience assesment of government. Communication Research, 7, 95-120.

Becker, M.H. (Ed.). (1974). The health belief model and personal health behaviar. Thorofare, NJ: C.B. Slack.

Becker, M.H., en Joseph, J.G. (1988). Aids and behavioral change to reduce risk: A review. American Journal of Public Health, 78, 394-410.

Beekers, M. (1982). Interpersconlijke vaardigheidstherapieen ooor kansamen. Lisse: Swets en Zeitlinger.

Bem, D.J. (1970). Beliefs, attitudes and human affairs. Belmont, CA: Brooks/Cole. 
Bem, D.J. (1972). Self-perception theory. In L. Berkowitz (Ed.), Adtances in experimental social psychology (Vol. 6). New Yorke Academic Press.

Berelson, B. (1942). The effects of print on public opinion. In D. Waples (Ed.), Print, radio and film in a democracy (pp. 41-64). Chicago: University of Chicago Press.

Berkowitz, L., en Geen, R.G. (1967). Stimulus qualities of the target of aggression: A further study. Joumal of Personality and Social Psychology, 5, 364-368.

Berkum, G. van (1985). Wat iedereen over drugs zou moeten weten: Evaluatie van de SIRE/FZA drugscampagne. Bilthoven: FZA.

Bernett, P., en Schöffel, U. (1982). Ursache und Prophylaxe von Skiverletzungen. Milnch. med. Wschr., 124, 178-182.

Berscheid, E., en Walster, E. (1978). Interpersonal attraction. Reading, MA: Addison-Wesley.

Best, J.A., Thomson, S.J., Santi, S.M., Smith, E.A, en Brown, K.S. (1988). Preventing cigarette smoking among school children. Annual Review of Public Health, 9, 161-201.

Best, J.A. (1980). Mass media, self management and smoking modification. In P.O. Davidson, en S.M. Davidson (Eds.), Behavioral medicine: Changing health lifestyles. New York: Brunner/Mazel.

Bettinghaus, E.P. (1986). Health promotion and the knowledge-attitudebehavior continuum. Preventive Medicine, 15, 475-491.

Biener, $K_{v}$ en Fassler, S. (1978). Sportunfalle. Bern: Verlag Hans Huber.

Blane, H.T. ( 1974). Education and mass persuasion as preventive strategies. In The prevention of alcohol problems. State of California: Office of Alcoholism, Health and Welfare Agency.

Bock, H. de, en Lil, J. van (1981). "Holocaust" in the Netherlands. In G. Wilhoit, en H. de Bock (Eds.), Mass communication review yearbook (Vol. 2, Pp. 639-647). Beverly Hills, CA: Sage.

Boniecki, G.J. (1978). Morn's concern over his future still in doubt. International Journal of Psychology, 13, 239-244.

Bosman, J., Hollander, E., Nelissen, P., Renckstorf, K, Wester, F., en Woerkum, C. van (1989). Het omgaan met kennis- en de vraag naar voorlichting: Vol. 1. Een multidisciplinair theoretisch referentiekader voor empirisch onderzoek naar de vraag naar voorlichting. Nijmegen: Katholieke Universiteit, Instituut voor toegepaste sociale wetenschappen.

Bouter, L.M., Knipschild, P.G., Peij, J.A., en Volovics, A. (1988). Sensation seeking and injury risk in downhill skiing. Personality and Individual Differences, 9, 667-673.

Bouter, L.M., en Knipschild, P.G. (1985). Risicofactoren van skilletsel. Tijdschrift voor Sociale Gezondheidszorg, 63, 846-851.

Bouter, L.M. (1988). Injury risk in downhill skiing: Results from an etiological casecontrol study conducted among Dutch skiers. Haarlem: Uitgeverij de Vrieseborch. 
Bouter, L.M. en Dongen, M. van (1991). Probleemanalyse. In V. Damoiseaux et al. (Red.), Gezondheidswoorlichting en -opvoeding. Van analyse tot effecter. Gewijzigde tweede druk (in press). Van Gorcum. Assen/Maastricht.

Bouwman, $\mathrm{H}$, en Jankowski, N. (Red.). (1989). Interactieve media op komst. Amsterdam: Otto Cramwinckel.

Bouwman, H. (1987). Televisie als cultuurschepper. Amsterdam: VU Uitgeverij.

Brehm, S.S., en Brehm, J.W. (1981). Psychological reactance: A theory of freediom and control. New Yotk Academic Press.

Budd, J., en McCron, R (1981). Health education and the mass media: Past, present and potential. In D.S. Leathar (Ed.), Health education and the media (pp. 33-45). London: Pergamon.

Buisman, W. (1987). Alcoholcampagnes over de grenzen. Tijdschrift voor Alcohol, Drugs en andere Psychotrope Stoffen, 13, 26-30.

Buisman, W. (1988). Mass media drug campaigns in Europe. Paper presented at the 35th International Congress on Alcoholism and Drugs Dependence, Oslo, Norway.

Buisman, W.R, en Kok, G.J. (1983). Alcohol- en drugsvoorlichting: een zwak middel? Tijdschrift voor Alcohol, Drugs en amdere Psychotrope Stoffen, 9, 137145.

Cacioppo, J.T., en Petty, RE. (1979). Attitudes and cognitive response: An electrophysiological approach. Journal of Personality and Social Psychology, 37, 2181-2199.

Cacioppo, J.T., en Petty, R.E. (1985). Central and peripheral routes to persuasion: The role of message repetition. In A. Mitchell, en $L_{w}$, Alwitt (Eds.), Psychological processes and advertising effects. Hillsdale, NJ: Erlbaum.

Cartwright, D. (1949). Some principles of mass communication: Selected findings of research on the sale of United States war bonds. Human Relations, 11, 253-267.

Centraal Bureau voor de Statistiek. (1986). Saciaal-culturele statistieken: Vakantie-onderzoek 1986 (voorlopige uitkomsten) (Mededelingen No. 1145). 's Gravenhage: Staatsuitgeverij.

Centraal Bureau voor de Statistiek (1986). Vakantie-onderzoek 1984. 's Gravenhage: Staatsuitgeverij.

Chaffee, S., en Mcleod, J. (1973). Individual versus social predictors of information seeking. Joumalism Quarterly, 50, 237-245.

Chaffee, S.H., en Wilson, D. (1977). Media rich, media poor: Two studies of diversity in agenda-holding. Joumalism Quarterly, 54, 466-476.

Chaiken, S. (1980). Heuristic versus systematic information processing and the use of source versus message cues in persuasion. Joumal of Personality and Social Psychology, 39, 752-766.

Chaiken, S., en Stangor, C. (1987). Attitude and attitude change. Anrual Review of Psychology, 38, 575-630.

Conger, J.J. (1981). Freedom and commitment: Families, youth and social change. American Psychologist, 36, 1475-1484. 
Cook, T.D., en Flay, B.R. (1978). The persistence of experimentally induced attitude change. In L Berkowitz (Ed.), Adonances in experimental social psychology (Vol. 2). New York: Academic Press.

Council of Europe. (1986). Sport for all: Sport injuries and their prevention. Council of Europe meeting, Papendal, The Netherlands.

Cuilenburg, J.J. van (1983). Overheidsvoorlichting in overvloed: Over vcorlichtingsonderzoek in het informatietijdperk. Amsterdam.

Cuilenburg, J.J. van (1987). Massacommunicatie. In B. Klandermans, en E. Seydel (Red.), Overtuigen en activeren: Publieksbeinvloeding in theorie en praktijk. Assen/Maastricht: Van Gorcum.

Cuilenburg, J.J. van, en Noomen, G.W. (1984). Communicatiewetenschap. Muiderberg: Coutinho.

Damoiseaux, V., Daamen, R, Wensen, C. van, en Bekkers, W. (1985). The influence of television health programmes on medical uptake. Paper presented at the Second International Conference on Health Education and the Media, Edinburgh, Great Britain.

Damoiseaux, V., Gerards, F.M., Kok, G.J., en Nijhuis, F. (1987). Gezondheidspoorlichting en -Oproeding: Van analyse tot effecten. Assen/Maastricht: Van Gorcum.

Damoiseaux, V., en Jongh, A. de (1988). Informationsmethoden im Hinblick auf die Vorbeugung vom Skiverleztzungen. Paper presented at the International congres of S.I.T.E.M.S.H., Courmayeur, Italia.

Damoiseaux, V., en Jongh, A de (1989). Preventie var skiblessures: Rapport van een gerandomiseerde interventiestudie. Maastricht: Rijksuniversiteit Limburg.

Damoiseaux, V., en Visser, A.Ph. (1988). Patientenvoorlichting: Een interdisciplinaire bethadering. Assen/Maastricht: Van Gorcum.

Davis, D.K, en Lee, J. (1980). Time serie analysis models for communication research. In P.R. Monge, en J.N. Capella (Eds.), Multivariate techriques in human communication research. New York: Academic Press.

De Witte, B., en Meyers, G. (1986). Epidemiologie van skiletseis: Oorzaken, traumatologie, preventie. Geneeskunde en Sport, 19, 196-204.

Dekker, E. (1969). Overheidswoorlichting in de verzorgingsmaatschappij. Rijswijk

Delouche, G. (1987). Bindings' release setting in alpine skiing. In C.D. Mote Jr., en R.J. Johnson (Eds.), Skiing Trauma and Safety: Sixth International Symposium, ASTM STP 938 (Pp. 202-211). Philadelphia: American Society for Testing Materials.

Dervin, B. (1981). Mass communication: Changing conceptions of the audience. In R.E. Rice, en W.J. Paisley (Eds.), Public communication campaigns, (pp. 71-88). Beverly Hills: Sage.

Dervin, B. (1983). Information as a user construct: The relevance of perceived information needs to synthesis and interpretation. In S.A. Ward, en L.J. Reed (Eds.), Knowledge structure and use: Implications for symthesis and interpretation. Philadelphia: American Society for Testing Materials. 
Dervin, B. (1989), Audience as listener and learner, teacher and confidante: The sense-making approach. In RE. Rice, en CK Atkin (Eds.), Public Conmunication Campaigns (pp. 67-86). Newbury Park: Sage.

Des Jarlais, D.C., en Friedman, S.R (1988). The psychology of preventing AIDS among intravenous drug users, American Psychologist, 43, 865-870.

Dongen, M. van, (1987). Evaluaties van GVO-interventies, In V. Damoiseawx et al. (Red.), Gezondheidswoorlichting en -Oproeding: Van analyse tot effecten. Assen/Maastricht: Van Gorcum.

Donohew, L, Palmgreen, P., en Duncan, J. (1980). An activation model of information exposure. Communication Monographs, 47, 295-303.

Donohew, L, en Tipton, L. (1973). A conceptual model of informationseeking, avoiding and processing. In P. Clarke (Ed.), New Models for mass communication research. Londen: Sage.

Dowling, P.A. (1982). Prospective study of injuries in United States Ski Association freestyle skiing 1976/1977 to 1979/1980. American Joumal of Sports Medicine, 5, 268-275.

Drop, W., en Vries, J.H.L. de, (1977). Taalbeheersing: Handboek voor taalhantering. Groningen: Wolters-Noordhoff.

Duchastel, P.C. (1981). Analyzing functions of illustrations in text. Philladelphia: Association for Educational Communication and Technology.

Duijker, H.C.J., en Dudink, A.C. (1976). Leerboek der psychologie (pp. 387-476). Groningen: Wolters-Noordhoff.

Duijker, H.C.J., en Vroon, P.A. (1981). Codex Psychologicus. Amsterdam/Brussel: Elsevier.

Dwyer, F.M. (1967). The relative effectiveness of varied visual illustrations in complementing programmed instruction. Joumal of Experimental Education, $36,34-42$.

Eagly, A.H., en Chaiken, S. (1984). Cognitive theories of persuasion. In L. Berkowitz (Ed.), Advances in experimental social psychology (Vol. 17, pp. 268359). New York: Academic Press.

Eijken, A, en Oosterzee, D. van (1990). Voorlichting: Effecten van voorlichting bif misdaadpreventie 1985-1988. Stafafdeling Informatievoorziening Directie Criminaliteitspreventie. Den Haag: Ministerie van Justitie.

Eiser, J.R, Pligt, van der J., Raw, M. en Sutton, S. (1985). Trying to stop smoking: Effects of perceived addiction, attributions for failure and expectancy of success. Journal of Behavioral Medicine, 8, 321-341.

Erbring, L., Goldenberg, E.N., en Miller, A.H. (1980). Front page news and real-world cues: $A$ new look at agenda-setting by the media. American Journal of Political Sciences, 24, 16-49.

Eriksson, E., en Johnson, RJ. (1980). The etiology of downhill ski injuries. Exerc. Spront Sci. Rev., 8, 1-17.

Ettema, J.S $S_{\text {, }}$ en Kline, F.G. (1977). Deficits, differences, and ceilings: Contingent conditions for understanding the knowledge gap. Communication Research, 4, 179-202. 
Ettlinger, C.F., en Johnson, RJ. (1982). The state of the art in preventing equipment-related alpine skd injuries. Clinics in Sports Medicine, 1, 199-207.

Evans, R.I., Rozelle, R.M., en Mittelmark, M.B. (1978). Deterring the onset of smoking in children: Knowledge of immediate physiological effects and coping with peer pressure, media pressure, and parent modeling. Joumal of Applied Social Psychology, 8, 126-135.

Farquhar, J.W. (1978). The community based model of life style intervention trials. American Joumal of Epidemiology, 108, 103-110.

Farquhar, J.W., Maccoby, N., en Solomon, D.S. (1984). Community applications of behavioral medicine. In W.D. Gentry (Ed.), Handbook of behavioral medicine. New York: Guilford Press.

Farquhar, J.W., Maccoby, N, en Wood, P.D. (1977). Community education for cardiovascular health. Lancet, 4, 1192-1195.

Fauconnier, G. (1981). Algemene communicatietheorie: Een overzicht van de wetenschappelijke theorieẽn over communicatie. Utrecht/Antwerpen: Het Spectrum.

Fazio, R.H. (1986). How do attitudes guide behavior? In R.M. Sorrentino, en E.T. Higgins (Eds.). Handbook of motization and cognitions: Foundations of social behavior (pp. 204-243). New York: Guilford.

Fazio, R.H., en Zanna, M.P. (1981). Direct experience and attitude-behavior consistency. In L. Berkowitz, (Ed.), Advances in experimental sucial psychology (Vol. 14, pp. 161-202). New York: Academic Press.

Fazio, R.H., Zanna, M.P., en Cooper, J. (1977). Dissonance and self-perception: An integrative view of each theory's proper domain of application. Joumal of Experimental Social Psychology, 13, 464-479.

Feather, N.T. (1969). Attitude and selective recall. Joumal of Personality and Social Psychology, 12, 310-319.

Ferree, H. (1977). Methoden om vooraf (reclame) boodschappen op hun effectiviteit te beoordelen. In $\mathrm{H}$. Ferree (Red.), Handboek voor effectieve communicatie. Deventer: Kluwer.

Ferree, H. (1983). Te koop: Welzijn, volksgezondheid on cultuur. Deventer: Kluwer/Van Loghum Slaterus.

Festinger, L.A. (1954). A theory of social comparison processes. Human Relations, $7,117-140$.

Festinger, LA. (1957). A theory of cognitive dissonance. New York: Stanford.

Fishbein, M., en Ajzen, I. (1975). Beliefs, attitude, intention, and behavior: An introduction to theory and research. Reading. MA: Addison Wesley.

Fisher, A, en Metaal, N. (1985). Motivatie. Psychologie, 3, 25-33.

Flay, B.R (1981). On improving the chances of mass media health promotion programs causing meaningful changes in behavior. In M. Meyer (Ed.), Health Education by Television and Radio. Munchen: Saur.

Flay, B.R. (1987). Evaluation of the development, dissemination and effectiveness of mass media health programming. Health Education Research, 2, 123129. 
FLay, BR (1987). Mass medila and smoking cessation: A critical review. American Jourmal of Public Health, 77, 153-160.

Flay, B.R, Ditecco, D., en Schlegel, R.P. (1980). Mass media in health promotion: An analysing using an extended information-processing model. Health Education Quariterly, 7, 127-147.

Flora, J.A, en Wallack, L (1990), Health promotion and mass media use: Translating research into practice. Health Education Research, 5, 73-80.

Galjart, B.F. (1971): Agricultural development and sociological concepts: A critique. Rural sociology, $36,31-42$.

Gairrick, J.G., en Kurland, L.T. (1971). The epidemiological significance of unreported ski injuries. Joumal of Safety Research, 3, 182-187.

Geen, R.G., en Quanty, M.B. (1977). The catharsis of aggresion. In L. Berkowitz (Ed.). Advances in experimental social psychology, Vol. 10, pp. 137). New York: Academic Press.

Geller, E.S., Winnet, RA, en Everett, P.B. (1982). New strategies for behavior change. New York: Pergamon.

Genova, B.KL., en Greenberg, B.S. (1979). Interests in news and the knowledge gap. Public Opinion Quarterly, 43, 79-91.

Gent, B. van, en Katus J. (Red.). (1990). Voorlichting: Theorieen, werkwijzen en terreinen. Houten/Deurne: Bohn Stafleu Van Loghum.

Gerbner, G., Gross, L., Morgan, M., en Signorielli, N. (1980). Aging with television: Images on television drama and conceptions of social reality. Jourtial of Communication, 30, 37-47.

Glynn, C.J., en McLeod, J.M. (1982). Public opinion, communication processes and voting decisions. In M. Burgoon (Ed.), Communication yearbook (vol. 6, pp. 759-774). Beverly Hills, CA: Sage.

Golding, P. (1980). The missing dimensions: News media and the management of social change. In E. Katz, en T. Szecsko (Eds.), Mass media and social change (pp. 63-81). Beverly Hills, CA: Sage.

Green, L.W. (1984). Modifying and developing health behavior. Annual Review of Public Health, 5, 215-236.

Green, L.W., Kreuter, M.W., Deeds, S.G ${ }_{n,}$ en Partridge, K.P. (1980). Health education planning: A diagnostic approach. Pallo Alto: Mayfield.

Green, L.W., en Lewis, J.M. (1986). Measurement and evaluation in health education awd health promotion. Palo Alto: Mayfield.

Greenberg, B.S., en Gantz, W. (1976). Public tellevision and taboo topics: The impact of VD blues. Publications Telecommunications Review, 4, 59-64.

Groot, A.D. de, en Medendorp, F.L., (1986). Term, begrip, theorie: Inleiding tot sigmifische begripsanalyse. Meppel: Boom.

Haes, W. de (1983). Gedragswetenschappelijk onderzoek ten dienste van Gezondheidswoorlichting en- oproeding. Lisse: Swets en Zeitlinger.

Halfens, RJ.G. (1985). Locus of control: De beheersingsorientatie in relatie tot ziekte- en gezondheidsgedrag. Proefschrift. Maastricht: Rijksuniversiteit Limburg. 
Handke, T., en Basler, H.D. (1987). Gesundheitserziehung durch T.V.-Spots: Eine empirische untersuchung des Gesundheitstips "Bleib gesund" "Pridvention, 1, 8-11.

Harberden, P. van, en Verklaar, E. (1988). De ontwikkelingsgang van overheidscommunicatie in Nederland: Een ideaaltypische schets. Communicatie $18,33-44$.

Hass, R.G., en Mann, R.W. (1976). Anticipatory belief chance: Persuasion or impression management? Joumal of Personality and Social Psychology, 34, 105-111.

Hauser, W. (1987). Prospektive Skiunfallstudie. Paper presented at the Seventh International Symposium on Skiing Trauma and Safety, Chamonix, France.

Hauser, W. (1987). Experimental prospective skiing injury study (Summary). Proceedings of the Seventh International Symposium on Skiing Trauma and Safety. Chamonix, France.

Hauser, $W_{\text {, }}$ en Gläser, H. (1985). Alpine Sküunfalle und Verletzungen: Häufigkeit, Risikofaktoren, Ursachen. Schriftenreihe des Deutschen Skiverband (Heft 14). München: Stiftung Sicherheit im Skisport des Deutschen Skiverbandes.

Hauser, W., en Gläser, H. (1987). Verletzungen beim alpinen Skilauf: Veränderungen und Trends. Deutsche Zeitschrift far Sportmedizin, 38, 191-198.

Hauwermeiren, P. van (1975). Leesbaarheidsformules voor informatieve nederlandse teksten. Spectator, 4, 499-521.

Heider, F. (1958). The psychalogy of interpersonal relations. New York: Wiley.

Heuvelman, A. (1989). Buiten beeld. Amsterdam/Lisse: Swets en Zeitlinger.

Hill, D., Rassaby, J., en Gray, N. (1982). Health education about breast cancer using television and doctor involvement. Preventive Medicine, 11, 43-55.

Hofland, C.I. (1948). Social Communication. Proceedings of the American Philosophical Society, 92, 371.

Holsti, O.R. (1969). Content analysis. In G. Lindzey, en E. Aronson (Eds.), The handbook of social psychology (Vol. 2, pp. 596-692). Reading, MA: Addison-Wesley.

Hoogerwerf, A. (1985). Van overheidsvoorlichting naar informatiebeleid. In J. Katus, en L.C. Beets (Red.), Actuele vraagstukken van de overheidsvoorlichting. Muiderberg: Coutinho.

Huisman, S. (1987). Beinvloeding van attituden en gedrag. In B. Klandermans, en E. Seijdel (Red.), Overtuigen en activeren: Publieksbeinvioeding in theorie en praktijk. Assen/Maastricht: Van Gorcum.

Jaffin, B. (1981). An epidemiologic study of ski injuries. The Mount Sinai Journal of Medicine, 48, 353-359.

Janis, I.L. en Mann, L. (1977). Decision making: A psychological analysis of conflict, choice and commitment. New York: The Free Press.

Jansen, C., Steehouder, M.F. (1989). Taalverkeersproblemen tussen ooerheid en burger: Een onderzoek naar verbeteringsmogelijkheden van voorlichtingsteksten en formulieren ten dienste van de uitvoering van wetten en regelingen. Proefschrift. Enschede: Technische Universiteit Twente. 
Jansen, C.J.M., en Steehouder, M.F. (1984). Beoordelen van tekstkwoaliteit. Enschede: Technische Hogeschool Twente, vakgroep toegepaste taalkunde.

Jansen, M., Damoiseaus, V., Jongh de A., en Huysse, M. (1990). De paden op, de lanen int: Verslag van een interventiestudie naar de verkeersveilige mobiliteit van ouderen. Maastricht: Rijksuniwersiteit Limburg.

Janz, N.K, en Becker, M.H. (1984). The health belief model: A decade later. Health Education Quarterly, 11, 1-47.

Jaspers, J.M.F. (1978). Determinants of attitudes and attitudes change. In $\mathrm{H}$. Tajfel, en C. Fraser (Eds.), Introducing Social Psychology (pp. 277-301). Harmondsworth: Penguin.

Jitta-Geertsema, I. (1986). De gezondheidswaarde van sport (WVC literatuurrapport nr. 31). Rijswijk Ministerie van Welzijn, Volksgezondheid en Cultuur.

Johnson, R.J., Ettlinger, C.F., Campbell, R.J., en Pope, M.H. (1980). Trends in skiing injuries: Analysis of a 6-year study (1972-1978). The American Joumal of Sports Medicine, 8, 106-113.

Jones, E.E., en Davis, K.E. (1965). From acts to dispositions: The attribution process in person perception. In L. Berkowitz (Ed.), Advances in experimental social psychology (Vol. 2). New York: Academic Press.

Jonkers, R. (1978). Gezondheidsgedrag. Rotterdam: Studiecentrum Oncologie.

Jonkers, R., Liedekerken, P., Haes, W.F.M. de, Kok, G.J., en Saan, J.A.M. (1988). Effectiviteit van Gezondheidsvoorlichting en -oproeding. Rijiswijk: Uitgeverij voor gezondheidsbevordering.

Jonsson, E. (1983). Does it pay to test bindings used in downhill skiing? A cost-benefit analysis of a ski safety campaign. Konsument Verket, 3, 1-13.

Kanters, H., en Wieberdink, L. (1990). Pretesten van schriftelijk voorlichtingsmateriaal. Assen: Van Gorcum.

Kaijser, R.E. (1990). Rijden onder invloed: Effectiviteit van een voorlichtingsprogramma. Proefschrift. Nijmegen: Katholieke Universiteit Nijmegen.

Katus, J., en Beets, L.C. (1985). Actuele vraagstukken van de overheidsvoorlichting. Muiderberg: Coutinho.

Katus, J., en Volmer, W.F. (Red.). (1985). Ontwikkelingslijnen van de overheidsvoorlichting: Muiderberg: Coutinho.

Katus, J. (1987). Overheidsvoorlichting. In B. Klandermans, en E. Seijdel (Red.), Overtuigen en activeren: Publieksbeinvloeding in theorie en praktijk (pp. 112-126). Assen/Maastricht: Van Gorcum.

Katz, E. (1980). Media events: The sense of occasion. Studies in Visual Communication, 6, 84-89.

Katz, E., Blumler, J.G., en Gurevitch, M. (1974). Uses and gratifications research. Public Opinion Quarterly, 4, 509-523.

Katz, E, en Szecsko, T. (Eds.). (1980). Mass Media and Social Change. Beverly Hills, CA: Sage.

Kegeles, S.M., Adler, N.E., en Irwin, Ch.E. (1988). Sexually active adolescents and condoms: Changes over one year in knowledge, attitudes and use. American Joumal of Public Health, 78, 460-461. 
Kelley, H.H. (1967). Attribution theory in social psychology. In D. Levine (Ed.), Nebraska Sympositum on motitation. Lincoln: University of Nebraska Press.

Kelley, H.H, en Thibaut, J. (1978). Interpersonal relations: $A$ theory of interdependence. New York: Wiley.

Kelman, H.C. (1970). Processes of opinion change. In W.G. Bernis, KK Benne, en R. Chin (Eds.), The planning of change. New York/Londen: Holt, Rinehart en Winston.

Kiesler, C.A., Collins, B.E., en Miller, N. (1969). Attitude Change. New York: Wiley.

Kiesler, S., Siegel, J., en McQuire, T.W. (1984). Social psychological aspects of computermediated communication. American Psychologist, 39, 1123-1134.

Klandermans, P.G. (1983). Participatie in een sociale beroeging: Een mobiliteitscampagne onderzocht. Amsterdam: VU-uitgeverij.

Klandermans, P.G. (1984). Mobilization and participation: Social psychological expansions of resource mobilization theory. American Sociological Review, $49,583-600$.

Klandermans, B., en Seydel, E. (Red.). (1987). Overtuigen en activeren: Publieksbeinvloeding in theorie en praktijk. Assen/Maastricht: Van Gorcum.

Klapper, J.T. (1960). The effects of mass communication. New York: Free Press.

Kline, F.G., en Pavlik, J.V. (1981). Adlolescent health information acquisition from the broadcast medium. In Meyer, M. (Ed.), Health Education by television and radio. Munchen: Saur.

Knipschild, P.G., en Bouter, L.M. (1987). Risk factors for ski trauma: A crash course of epidemiologic methods with special refence to case-control studies [Summary]. Proceedings of the Seventh International Symposium on Skiing Trauma and Safety. Chamonix, France.

Kok, G.J. (1979). Studies in attitude en gedrag II: Attitude, sociale normen en energiebesparend gedrag. Rijksuniversiteit Groningen: Heymans Bulletins.

Kok, G.J. (1985). Een model van gedragsverandering via voorlichting. Nederlands Tijdschrift voor de Psychologie, 40, 71-76.

Kok, G.J. (1986). Gezondheidsmotivering: GVO als wetenschapsgebied. Oratie. Maastricht: Rijksuniversiteit Limburg.

Kok, G.J. (1987). De rol van angst bij gedragsverandering door voorlichting. In A.Ph. Visser, en W.F.M.de Haes (Red.), Angst en Gezandheidswoorlichting en -Oproeding (G.V.O.) (PP. 28-36). Amsterdam: VU Uitgeverij.

Kok, G.J. (1987). Theorieën over gedragsbeinvloeding. In V. Damoiseaux et al. (Red.), Gezondheidswoorlichting en -Oproeding: Van analyse tot effecten (pp. 5376). Asser/Maastricht: Van Gorcum.

Kok, G.J., en Green, L.W. (1990). Research to support health promotion in practice: A plea for increased co-operation. Health Promotion International, 5, 303-307.

Kok, G.J., Meertens, R.W., en Wilke, H.A.M. (1987). Voorlichting en verandering. Groningen: Wolters-Noordhoff. 
Kok, G.l., en Siero, S. (1985). Tin recycling: Awareness, comprehension, attitude, intention and behavior. Joumal of Economic Psychology, 6, 157-173.

Koomen, W. (1988). Sociale perceptie en cognitie. In R.W. Meertens, en J. von Grumbkow (Red.). Sociale psychalogie. Groningen/Heerlen: WoltersNoordhoff/Open Universiteit.

Kranenborg, H. (1983). Sportbeoefening en blessure: Tijdschrift Sociale Geneeskunde, $60,224-227$.

Kreeft, H., Vroege P., en Zondervan, F.(1982). Moedertaalonderwijs in onttvilkeling: een overzicht van onderzoek tot 1981. Muiderberg: Coutinho.

Krueger, R.A. (1988). Focus groups: A practical guide for applied research. Beverly Hills, CA: Sage.

Kuriyama, S., en Fujimaki, S. (1987). Current trends in ski-injuries and their relationship to recent changes in ski-equipment. In C.D. Mote Jr., en R.J.Johnson (Edk.), Skiing Trauma and Safety: Sixth International Symposium, ASTM. Philadelphia: American Society for Testing Materials.

Langer, I. (1974). Verständlichkeit in Schule, Verwaltung, Politik und Wissenschaft. München.

Langer, I., Schultz von Thun, F., en Tausch, R. (1981). Sich verständlich ausdrucken. München, Ernst Reinhardt Verlag.

Lau, R., Kane, R., Berry, S., Ware, J., en Roy, D. (1980). Channeling Health: A review of the evaluation of the televised health campaigns. Health Education Quarterly, 7, 56-89.

Lazarus, R. (1980). The stress and coping paradigms. In C. Eisdorfer, en D. Cohen (Eds.), Theoretical bases for psychopathology (pp. 177-214). New York: Spectrum.

Lazersfeld, P.F., en Merton, R.K (1948). Mass communication, popular taste, and organized social action. In L. Byron (Ed.), The communication of ideas. New York: Harper.

Leeuw, E. de, (1988). The sane revolution. Health promotion: Backgrounds, scope, prospects. Assen/Maastricht: Van Gorcum.

Leeuw, E. de (1989). Health policy: An exploratory inquiry into the development of policy for the new public health in the Netherlands. Proefschrift. Maastricht: Rijksuniversiteit Limburg.

Lefebvre, C.R., en Flora, J.A. (1989). Social marketing and public health interventions. Health Education Quarterly, 15, 299-315.

Lenz, L. (1989). Schrijven van voorlichtingsteksten. Utrecht: Rijksuniversiteit Utrecht, vakgroep Nederlands.

Leventhal, H. (1970). Findings and theory in the study of fear communications. In L. Berkowitz (Ed.), Adtunces in experimental social psychology (Vol. 5). New York: Academic Press.

Leventhal, H. (1984). A perceptual-motor theory of emotion. In L. Berkowitz (Ed.), Advances in experimental social psychology (vol. 17). New York: Academic Press.

Leventhal, H., Safer, M.A., en Clearly, P.D. (1980). Cardiovascular risk modification by community-based programs for life-style change: Comments on 
the Stanford study. Joumal of Consulting and Clinical Psychology, 48, 150158.

Levie, W.H., en Lentz, R. (1982). Effects of text illustrations: A review of research. Joumal of Educational Communication and Technology, 30, 195-232.

Luykx, J.B. (1987). De effecten van de Sire-campagne. SOA-Bulletin, 6, 6-8.

Luyko, J.B., Marsman, G.W., en Rijt, van der G. (1988). Kennis over Aids in Nederland en de determinanten van deze kennis. GVO/Preventie, 1, 21-30.

Maccoby, N., en Alexander, J. (1980). Use of media in lifestyle programs. In P.O. Davidson, en S.M. Davidson (Eds.), Behavioral Medicine: Changing health lifestyles (pp. 351-370). New York: Bruner/Mazel.

Maccoby, N., en Solomon, D. (1981). Experiments in risk reduction through community health education. In M. Meyer (Ed.), Health Education by television and radio (pp. 140-166), Munchen: Saur.

Madsen, KB. (1974). Modem theories of motivation. Copenhagen: Munksgaard.

Maletzke, G. (1963). Psychologie der Massenkommunikation. Hamburg: Verlag Hans Bredow Institut.

Marktplan adviesgroep (1988). F-Sys Vuurwerk Eindrapportage van een onderzoek naar het effect van de Sire-campagne "Verknal je toekomst niet". Amsterdam.

Marlatt, G.A., en Gordon J.R. (1985). Relapse Prevention: Maintance strategies in the treatment of addictive behaviors. New York/London: Guilford.

Marsman, G.v en Peeters, G.J. (1979). Stoppen met roken. Nijmegen: Instituut voor Toegepaste Sociologie.

Maslow, A. (1954). Motization and Personality, New York: Harper Row.

Massaro, D.W. (1988). Communication and Persuasion: Central and peripheral routes to attitude change (Review). American Joumal of Psychology, 101, 155-156.

Mastenbroek, J. (1987). Overheidsvoorlichting. In J. Groenendijk, G. Hazekamp, en J. Mastenbroek (Red.), Public relations en voorlichting: Beleid, organisatie en uitwoering (pp. 99-116). Alphen aan den Rijn: Samson.

McAlister, A. (1976). Television as a medium for delivering behavior therapy. New York: Association for the advancement of Behavior Therapy.

McAlister, A., en Berger, E.D. (1979). Media for Community Health Promotion. In P.M. Lazes (Ed.), The handbook of Health Education (pp. 163-170). Germantown, MD: Aspen Systems Corporation.

McAlister, A., Puska, P., Salonen, J.T., Tuomilehto, J., en Koskela, K (1982). Theory and action for health promotion: Illustrations from the North Karelia project. American Joumal of Public Health, 72, 43-50.

McCombs, M.E., en Shaw, D.L. (1972). The agenda-setting function of mass media. Public Opinion Quarterly, 36, 176-187.

McCron, R, en Budd, J. (1979). Mass communication and health education. In I. Sutherland (Ed.), Health education: perspectives and choices. London: George Allen en Unwin.

McGuire, W.J. (1960). Cognitive consistency and attitude change. Journal of Abnomal and Social Psychology, 60, 343-353. 
McGuire, W.J. (1981). Theoretical Foundations of Campaigns. In E.Rice, en W.J. Paisley (Eds.), Public Communication Campaigns (pp. 15-41). Beverly Hills, CA: Sage.

McGuire, W.J. (1984). Improving the health status of adults by inducing changes in institutional and personal behavior. Preventive Medicine, 13, 299.319.

McGuire, W.J. (1985). Attitudes and attitude change. In A. Lindzey, en E. Aronson (Eds.), Handbook of Social Psychology (Vol. 2, pp. 233-346). New York: Random House.

McGuire, W.J. (1986). The myth of massive media impact: Savagings and salvagins. In G. Comstock (Ed.), Public Communication and behavior (Vol. 1, pp. 175-234). Orlando: Academic Press.

McGuire, W.J. (1989). Theoretical foundations of campaigns. In R. Rice, en C.K. Atkin (Eds.), Public Communication Campaigns (pp. 15-45). Beverly Hills, CA: Sage.

McKnight, C. (1978). Is man interested in his future? A reply to Bonieckil. International Joumal of Psychology, 13, 159-162.

McLeod, J.M., Atkin, C.K, en Chaffee, S.H. (1972). Adolescents, parents and television use: Adolescents self-report measures from Maryland and Wisconsin samples. In G.A. Comstock, en E.A. Rubinstein (Eds.), Teleoision and social behavior (Voll. 3, pp. 177-238). Washington, DC: U.S.Government Printing Office.

McLeod, J.M., Becker, L.B., en Byrnes, J.E. (1974). Another look at the agenda-setting function of the press. Communication Research, 1, 131-166.

McLeod, J.M., en Blumer, J.G. (1987). The macrosocial level of communication science. In C.R. Berger, en S.H. Chaffee (Eds.), Handbook of communtication science (pp. 271-322). Newbury Park: Sage.

McLeod, J.M., Bybee, C.R., en Durall, J.A. (1979). Equivalence of informed pacitical participation: The 1976 presidential debates as a source of influence. Communication Research, 6, 463-487.

McQuail, D. (Ed.). (1972). Sociology of Mass Communication. London: Sage.

McQuail, D. (1983). Mass communication theory: An introduction. London: Sage.

Meiden, A van der (1975). Massacommunicatie en ethiek Intermediair, 11, 19.

Meiden, A. van der, en Fauconnier, G. (1986). Profiel en Professie: Inleiding in de theorievorming van public relations. Leiden: Martinus Nijhoff.

Meij, J.M. de (1987). Vrijheid van informatie in Nederland. Informatie en informatiebeleid, $5,35-45$.

Mendelsohn, H. (1973). Some reasons why information campaigns can succeed. Public Opinion Quarterly, 37, 50-61.

Mendelsohn, H. (1981). Compliance and rejection: Psychological strategies for effective public communication on behalf of health. In D.S. Leathar (Ed.), Health education and the media (pp. 3-17). Oxford: Pergamon. 
Mendelsohn, H. (1985). Lessons from a national prevention campaign. In D.S. Leathar, G. Hastings, KM. O'Reilly en J.K Davis (Eus.), Health education and the media (pp. 133-137). Londen: Pergamon.

Midden, C.J.H., Daamen, D.D.L., Lans, I.A. van der, en Verplanken, B. (1988). Voorlichting over straling: Evaluatie oan een massamediale campagne. Leiden: Rijksuniversiteit Leiden, werkgroep Energie- en Milieuonderzoek.

Midden, C.J.H., en Weenig, W.H. (1982). Energiebesparing door gedragsbetnvloeding. Den Haag: Vuga-uitgeverij.

Mielke, KW., en Swinehart, J.W. (1976). Evaluation of the feeling good television series. New York: Children's Television Workshop.

Montfoort, G., Galen, W. van, en Harris, S.(1988). Ongevallen in Nederlantd. Amsterdam: Stichting Consument en Veiligheid.

Mortensen, M.S. (1982). Informationsvermittlung durch Massenmedien: Sind die verschiedene Medien gleich effective? Media Perspectiven, 6, 404-408.

Moschis, G.P. (1980). Consumer information use: Individual versus social predictors. Communication Research, 7, 139-160.

Mudde, A. (1987). Stoppen met raken: De rol van persoonlijke effectiviteit, succesverwachting en aorzakelijke attributies. GVO-cahier no. 31. Maastricht: Rijksuniversiteit Limburg.

Murphy, R.D. (1980). Consumer responses to cigarette health warnings. In L.A. Morris (Ed.), Product labeling and health risks (report no. 6, pp. 13-21). New York: Branbury Reports.

Muskes, G.J., en Oorschot, W. van (1985). Informatiebehoeften, informatiezoekgedrag en moeilijke doelgroepen: Samenvatting van het gelijknamige hoofdrapport. Tilburg: IVA.

Nagel, A., en Mösch, S. (1987). Test devices for ski bindings sold in sports shops: State of the art and future development. In C.D. Mote Jr., en R.J. Johnson (Eds.), Skiing Trauma and Safety: Sixth International Symposium, ASTM STP 938 (pp. 217-224). Philadelphia: American Society for Testing Materials.

Newcomb, T.M. (1943). Personality and social change: Attitude formation in a social community. New York: Holt, Rinehart en Winston.

Nuttin, J.R. (1975). The illusion of attitude change: Towards a response contagion theory of persuasion. Londen/ New York: Academic Press.

Nuttin, J.R. (1976). Motivation and reward in human learning: A cognitive approach. In W.K. Estes (Ed.), Handbook of learning and cognitive processes (Vol. 3., pp. 247-281). New York: Erlbaum.

Nuttin, J.R (1981), De menselijke motivatie: Van behoefte tot gedragsproject. Deventer: Van Loghum Slaterus.

O'Keefe, M.T. (1971). The anti-smoking commercials: A study of television's impact on behavior. Public Opinion Quarterly, 35, 242-248.

Oh, S.(1981). Todliche Schadelhirnerletzung durch Ski-Unfalle und inre Prophylaxe. Schweiz Zeitschrift Sportmedicin, 4, 137-141.

Oh, S.(1982). Depressed skullfracture in skiing and its experimental study. International Joumal Sports Medicine, 3, 169-173. 
Oortmarssen, G. vain, Kok, G.J. (1987). Illustraties in de voorlichting. GVOcahier no. 11. Maastricht: Rijksuniversiteit Limburg.

Oskamp, S. (1977). Attitudes and opinions. Englewood Cliffs, N]: Prentice-Hall.

Page, B.I, en Shapiro, RY. (1984). Presidents as opinion leaders: Some new evidence. Policy Studies Joumal, 12, 649-662.

Paisley, W.J. (1981). Public Communication Campaignis: The American Experience. In R.E. Ríce, en W. J. Paisley (Eds.), Public Communication Campaigns (pp. 15-40). Beverly Hills, CA: Sage.

Pallak, M.S, Cook, D.A., en Sullivan, I.J. (1980). Commitment and energy conservation. Applied Social Psychology Annual, 1, 235-253.

Palmgreen, Ph., Wenner, L.A., en Rayburn, J.D. (1980). Relations between gratifications sought and obtained. Communication Research, 7, 161-192.

Patterson, S.C. (1982). Campaign spending in contests for governor. Westem Political Quarterly, 35, $457-477$.

Peterson, RA. (1981). Measuring culture, leisure, and time use. Annals of the American Academy of Political and Social Sciences, 453, 1969-1979.

Peterson, P.E., Jeffrey, D.B., Bridgewater, C.A, en Dawson, B. (1984). How pronutrition television programming affects children's dietary habits. Decollopmental Psychology, 20, 55-63.

Petty, R.E., en Cacioppo, J.T. (1986). Communication and persuasion: Central and peripheral routes to attitude change. New York: Springer.

Philipsen, H. (1988). Gezondheidszorg als project en bejegening: Waarden ten aanzien tan ziekte, gezondheid en samenleving. Maastricht" Rijksuniversiteit Limburg.

Phillips, D.P. (1982). The impact of fictional television stories on U.S. adult fatalities: New evidence on the effect of the mass media on vilolence. American Journal of Sociology, 87, 1340-1359.

Phillips, D.P. (1983). The impact of mass media violence on U.S. homicides. American Sociological Review, 48, 560-568.

Pool de Sola, 1. (1983). Tracking the flow of information. Science, 221, 609613.

Powell, M.C., en Fazio, R.H. (1984). Attitude accessibility as a function of repeated attitudinal expression. Personality and Social Psychology Bulletin, $10,139-148$.

Puska, P. Tuomiletho, J., Salonen, J. et al. (1981). The North Karelia project: Evaluation of a comprehensive community programm for control of cardiowascular disease in 1972-77 in North Karelia, Finland. Public health in Europe, WHO/Euro monograph series.

Pruitt, D.G., en Kimmel, M.J. (1977). Twenty years of experimental gaming: Critique, synthesis and suggestions for the future. Annual Review of Psychology, 28, 363-392.

Quellet, G., en Prince, P. (1987). Behaviour and attitudes of downhill skiers with regard to safety; Part I: Perceptions of causes of accidents and preventive measures [Summary]. Proceedings of the Seventh International Symposium on Skiing Trawma and Safety. Chamonix, France. 
Quellet, G., en Prince, P. (1987). Behaviour and attitudes related to safety of downhill skiers; Part II. Perceptions of danger and safe behaviour [Summary]. Proceedings of the Seventh International Symposium on Skiting Trauma and Safety. Chamonix, France.

Raaij, W.F. van (1984). Affectieve en cognitieve reacties op reclame en voorlichting. Massacommunicatie, 12, 262-270.

Raaij, W.F. van, en Verhallen, T.M.M. (1980). Huishoudelijk gedrag en stookgasverbruik. Economisch Statistische Berichten ${ }_{r}$ januari 1980.

Ray, M.L. (1973), Marketing communication and the hierarchy-of-effects. In P. Clarke (Ed.), New Models for communication research (pp. 147-176). Beverly Hills, CA: Sage.

Ray, M.L (1977). When does consumer information processing research actually have anything to do with consumer information processing? In W.D. Perreault (Ed.), Adtrances in Consumer Research (Vol. 4, pp. 372-375).

Reilly, T., en Lees, A. (1984). Exercise and sports equipment: Some ergonomic aspects. Applied Ergonomics, 15, 259-279.

Renckstorf, K, en Nelissen, P. (1988). Het omgaan met kennis- en de vraag naar voorlichting: Achtergronden en uitgangspunten voor fundamenteel onderzoek Massacommunicatie, 15, 291-316.

Rens, Th.J.G. van (1982). Sport en gezondheid: Orthopedische aspecten. Medisch Contact, 37, 1283-1289.

Rescon Research en Consultancy (1989). Eindrapport exaluatie Way of Life compagne. Culemborg.

Restak, R.M. (1982). The self-seekers. New York: Doubleday.

Richman, L.A., en Urban, D. (1978). Health education through television: Some theoretical applications. Intermational Journal of Health Education.

Riel, C.B.M. van (1979). Effectenonderzoek en voorlichting: Aanbevelingen vanuit de massacommunicatieve theorievorming met betrekking tot het voorlichtingseffectenonderzoek. Nijmegen: Instituut voor Massacommunicatie.

Riel, C.B.M. van (1986). Overheidsvoorlichting en intermediaire kaders: Een studie naar de intermediaire rol cuan organisaties in het woorlichtingsproces oan de centale overheid. Delft: Eburon.

Rijt, G.A.J. van der, en Baan, B. (1984). Massacommunicatie als gangmaker voor interpersoonlijke communicatie: Een effectieve manier van overredende communicatie. Tijdschrift voor alcohol en drugs, 10, 9-18.

Rijt, G.A.J. van der, Buysse, A., en Luijkx, J.B. (1989). Geslachtsziektenvoorlichting en de kenniskloofhypothese. Massacommunicatie, 17, 182-191.

Roberts, D.F., en Maccoby, N. (1985). Effects of Mass Communication. In G. Lindzey, en E. Aronson (Eds), Handbook of Social Psychology (Voll. 2, pp. 539-598). New York: Random House.

Robertson, L.S. (1976). The great seat bell campaign flop. Journal of Communication, $26,41-45$.

Robinson, J.P. (1969). Television and leisure time: yesterday, today and (maybe) tomorrow. Public Opinion Quarterly, 33, 210-223. 
Robinson, J.P. (1976). Interpersonal influence in election campaigns: Twostep flow hypotheses. Public Opinion Quarterly, 40, 304-319.

Rogers, E.M. (1973). Communication strategies for family planning. New York: Free Press.

Rogers, E.M. (1983). Diffusion of innorations (3rd ed.). New York: Free Press.

Rogers, EM. (1986). Communication technology: The new media in society. New York, Free Press.

Rogers, EM., en Kincaid, D.L. (1981). Communication networks: Toward a new paradigm for research. New York Free Press.

Rogers, E.M., en Shoemaker, F.F. (1971). Communications of Innovations. New York: Free Press.

Rogers, E.M., en Storey, J.D. (1987). Communication campaigns. In C.R. Berger, en S.H. Chaffee (Eds.); Handbook of communication science. Newbury Park, CA: Sage.

Rogers, RW. (1975). A protection motivation theory of fear appeals and attitude change. Joumal of Psychology, 34, 54-61.

Rogers, $\mathbb{R}$ W. (1983). Cognitive and physiological processes in fear appeals and attitude change: $A$ revised theory of protection motivation. In J.T. Cacioppo, en R.E. Petty (Eds)), Social psychophysiology: A source book (pp. 153-176). New York: Guilford.

Rogers, R.W., en Mewborn, C.R (1976). Fear appeals and attitude change: Effects of threat's noxiousness, probability of occurance and the efficacy of coping responses. Joumal of Personality and Social Psychology, 34, 54-61.

Rogmans, W., en Berghahn, A. (1984). Evaluatiecampagne vuurwerk en veiligheid. Massacommunicatie, 12, 161-165.

Röling, N.G. (1988). Extension science: Information systems in agricultural development. Cambridge: Cambridge University Press.

Röling, N.G. (1989). De moeilijk bereikbaren: "Last frontier" voor GVO. GVO/Preventie, 10, 1-7.

Romano, R. (1984). Pre-testing in health communications. Bethesda, MD: National Cancer Institute.

Ronis, D.L., Yates, J.F., en Dirscht, J.P. (1989). Attitudes, decisions, and habits as determinantss of repeated behavior. In A.R. Pratkanis, S.J. Breckler, en A.G. Greenwald (Eds.), Attitude structure and function (pp. 213-239). Hillsdale, NJ: Erlbaum.

Roomer, I. (1987). De praktijk van marketing-communicatie: Achtergronden van concepten, teksten en ontwerpen. Deventer/Antwerpen: Kluwer.

Rooyers, T. (1986). Verkeersveiligheidsvoorlichting. De Psycholoog, 12, 606-610.

Rosen, J.C., Johnson, R.J., Lefebre, M.F., en Pope, M.H. (1982). Behavioral determinants of skiers" failure to adjust release bindings. Clinics in Sports Medicine, 1, 209-215.

Rosenberg, M.J., en Hovland, C.I. (1960). Cognitive, affective and behavioral components of attitudes. In C.I. Hovland, en M.J. Rosenberg (Eds.), Attitude of ganization and change. New Haven: Yale University Press. 
Ross, CK (1981). Factors influencing succesful preventive health education. Health Education Quarterly, 8, 331-343.

Ross, H.S., en Mico, P.R. (1980). Theory and practice in heath education. Palo Alto: Mayfield.

Rossi, P.H. (1979). Evaluation: A systematic approach. Beverly Hills, CA: Sage.

Rotter, J.B. (1966). Generalized expectations for internal versus extemal control of reinforcements. Psychological Monographs, 80, 609.

Rouwenhorst, W. (1977). Leren Gezond te zijn? Groningen: Wolters-Noordhoff.

Ruesch, J., en Bateson, G. (1951). Commumication, the sacial matrix of psychiatry. New York

Reelick, F., en Haes, W. de (1988). De effectiviteit van geslachtsziekten voorlichting. In Jonkers et al. (Red.), Effectiviteit van Gezondheidswoorlichting en oproeding (pp. 218-226). Rijswijk: Uitgeverij voor gezondheidsbevordering.

Rushton, J.P. (1982). Television and prosocial behavior. In D. Pearl, L. Bouthilet, en J. Lazar (Eds.), Television and behavior: Ten years of scientific progress and implications for the eighties (pp. 248-257). Rockville, MD: National Institute of Mental Health.

Rüstow, A (1980). Freedom and domination: A historical critique of civilization. Princeton, NJ: Princeton University Press.

Sawyer, A (1981). Repetition, cognitive responses, and persuasion. In $R$. Petty, T. Ostrom, en T. Brock (Eds.), Cognitive responses in persuasiow, Hillsdale, N]: Eribaum.

Schachter, S. (1959). The psychology of affiliation. Stanford, CA: Stanford University Press.

Schanie, C.F., en Sundel, M.(1978). A community mental health innovation in mass media preventive education: The Alternatives Project. American Joumal of Community Psychology, 6, 573-581.

Schaps, E., Dibartolo, R, en Moskowitz, J. (1981). A review of 127 drug abuse prevention program evaluations. Joumal of drug issues, 11, 17-43.

Schmeling, D.G., en Wotring, C.E. (1980). Making anti-drug abuse advertising work. Joumal of Advertising Research, 20, 3, 33-37.

Schramm, W., en Roberts, D.F. (1971). The process and effects of mass communication. Urbana, $\mathbb{L}$.

Schramm. W. (1962). Mass communication. Annual Review of Psychology, 13, $251-284$.

Schumacher, G.M., en Waller R. (1985). Testing design alternatives: A comparison of procedures. In T.M. Duffy, en R. Waller, R. (Eds.), Designing usable texts. London.

Schwartz, S.H. (1977). Normative influences on altruism. In L. Berkowitz (Ed), Advances in experimental social psychology (Vol. 10, Pp. 221-279). New York: Academic Press.

Sears, D.O., en Freedman, J.L. (1967). Selective exposure to information: A critical review. Public Opinion Quarterly, 31, 194-213. 
Seligman, C., en Darley, J.M. (1976). Feedback as a means of reducing energy comsumption. American Sociological Association.

Seligman, ME.P. (1975). Hellplessness, San Francisco: Freeman.

Sepstrup, D. (1980). Consumption of mass communication: Constructionn of a model on information consumption behavior. Research in Marketing, 3, 166194.

Seydel, E. (1989). Kanker en het algemene publiek: Experimenteren met kankerwoorlichting (WMW-publikatie 2). Enschede: Faculteit Wijsbegeerte en Maatschappijwetenschappen Universiteit Twente.

Shealy, J.E. (1974). Epidemiology of ski injuries: Effect of method of skill acquisition and release binding accident rates. Human Factors, 16, 459-473.

Sherman, S.J. (1980). On the self-erasing nature of errors of prediction. Joumal of Personality and Social Psychology, 39, 211-221.

Siero, S. (1988). Voorlichting onderzocht in een antal empirische studies. Proefschrift. Maastricht: Rijksuniversiteit Limburg.

Siero, S., Boon, M.E., Kok, G.J., en Siero, F. (1987). Een programma ter bevordering van brandstofbesparend rijgedrag bij de PTT: Een evaluatieonderzoek. Nederiand's Tijdschrift voor de PSychologie, 40, 105-115.

Spronk, V., en Warmenhoven, N. (1982). Patientenvoorlichting in de huisartsenpraktijk: Inventarisatie van meningen van huisartsen. Utrecht: Nederlands Huisartsen Instituut.

Staatsen, R.J. (1980). De relatie tussen formele en informele massacommunicatie. Amsterdam: Subfaculteit Psychologie/Baschwitz Instituut.

Stappers, J.G. (1966). Publicistiek en communicatiemodellen. Proefschrift. Nijmegen: Katholieke Universiteit Nijmegen.

Stappers, J.G. (1986). Bugers, Boeren en Buitenlui. Oratie. Nijmegen: Katholieke Universiteit Nijmegen.

Stappers, J.G. (1988). Massacommunicatie. Een inleiding. Amsterdam.

Stappers, J.G., Reijnders, A.D., en Moller, W.A.J. (1990). De werking van massamedia. Een overzicht van inzichten. Amsterdam: De Arbeiderspers.

Steehouder, M.F. (1979). Leren communiceren: Procedures voor mondelinge en schriftelijke communicatie. Groningen: Wolters-Noordhoff.

Steehouder, M.F., en Jansen, C. (1982). De effectiviteit van voorlichtingsteksten. Tijdschrift voor Taalbeheersing, 4, 293-313.

Steehouder, M.F., Janssen, C., Staak, J. van der, en Woudstra, E. (1979). Leren communicerew. Enschede: Technische Hogeschool Twente.

Stern, P.C. (1978). When do people act to maintain common ressources? A reformulated psychological question for our terms. International Journal of Psychology, 13, 149-158.

Stewart, A. (1985). The design of print for health education: Principles for communication. In D.S. Leathar, G.B. Hastings, K.M. O'Reilly, en J.K. Davis (Eds.), Health education and the media. Londen: Pergamon.

Stichting Consument en Veiligheid (1987). Veiligheidsstudie skitn. Amsterdam. 
Strecher, V.J., DeVellis, B.M., Becker, M.H., en Rosenstock, IIM. (1986). The role of self efficacy in achieving health behavior change. Health Edtication Quarterly, 13, 73-91.

Stromme, S.B., Frey, H., en Harlem, O.K (1982). Physical activity and health. Scandinavian Journal Social Medicine (supplement), 29, 9-36.

Sutton, S.R. (1982). Fear-arousing communications: A critical examination of theory and research. In J.R.Eiser (Ed.), Social Psychology and Behavioral Medicine (pp. 303-337).

Tapper, E.M. (1978). Ski injuries from 1939 to 1976: The Sun Valley experience. American Journal of Sports Medicine, 6, 114-121.

Taylor, D.G. (1982). Pluralisatic ignorance and the spiral of silence: A formal analysis. Public Opinion Quarterly, 46, 311-335.

Taylor, T.W. (1986). Competitive marketing strategies. Radnor, PA: Chilton.

Thibaut, J.W., en Kelley, H.H. (1959). The social psychology of groups. New York: Wiley.

Tichenor, P.T., Donohue, G.A, en Olun, C. (1980). Community conflict and the press. Newbury Park, CA: Sage.

Tones, B.K (1981). The use and abuse of mass media in health promotion. In D.S. Leathar, G.B. Hastings, en J.K. Davis (Eds.), Health education and the media. Londen: Pergamon.

Turnbull, S.R. (1985). The training of health professionals for effective use of mass media in health education. In D.S. Leathar, G.B. Hastings, K.M. O'Reilly, en J.K. Davies (Eds.), Health education and the media. London: Pergamon.

Tyler, T.R, en Cook, F.L. (1984). The mass media and judgments of risk: Distinguishing impact on personal and societal level judgments. Joumal of Personality and Social Psychology, 47, 693-708.

Udry, J.R. (1974). The media and family planning. Chapel Hill, NC: Carolina Population Center.

Ungerholm, S., en Gustavsson, J. (1985). Skiing safety in children: A prospective study of downhill skiing injuries and their relation to the skier and his equipment. International Joumal of Sports Medicine, 6, 353-358.

Veen, P. (1985). Sociale psychologie toegepast. Alphen aan den Rijn: Samson.

Veen, $P_{\text {s, }}$ en Wilke, H. (1984). De kern van de sociale psychologie. Deventer. Van Loghum Slaterus.

Veihelmann, D. (1972). Skiunfälle und ihre Abhängigkeit von ausseren Faktoren. Acta Traumatica, 2, 57-62.

Verhallen, T., en Pieters, R. (1984). Attitude theory and behavioral costs. Journal of Economic Psychology, 5, 223-249.

Verplanken, B. (1989). Persuasive communication of technological risks: A test of the elaboration likelihood model. Proefschrift. Rijksuniversiteit Leiden.

Vierkant, P. (1987). Televisiekijkers in Nederland: Een onderzoek naar het televisie kijkgedrag ran de Nederlandse bevolking. Proefschrift. Groningen: Rijksuniversiteit Groningen. 
Voort, T.H.A. van der, en Beekenkamp, F. (1978). Edukatiece televisie voor tolwwssenten: Een researchowerzicht. Hilversum: NOS.

Vroom, B. (1987). Publieksonderzoek met behulp van de plus-en-minmethode. Tijulsownt woor toulbeheersing, 9, 256-272.

Wallack, L. (1981) Mass media campaigns. The odds against finding behavior change. Health Education Quarterly, 8, 2019-260.

Walle-Sevenster, J de, Beucken, L. van den, en Röling, N.G. (1986). Voorlichting aan achterstandsgroepen. Den Haag: Vuga.

Wallston, B.S, en Wallston, KA. (1978). Locus of control and health: A rewiew of the literature. Health Education Monographs, 6, 107-117.

Warner, KE. (1977). The effects of the anti-smoking campaign on cigarette consumption. American Jowrnal of Public Health, 67, 645-650.

Weenig, W.H. (1989). Voarlichting aan achterstandsgroepen via de sociale netwerkbetadering: Evalwatie wan een voorlichtings-experiment (Onderzoelksrapport no. 70). Den Haag: SWOKA.

Weiner, B. (1986). An attributional theory of motivation and emotion. New York: Springer.

Werkgroep GVO en Massacommunicatie (1986). Voorlichting en sportblessures: Een inleiding. Den Haag: Ministerie van WVC, afd. Voorlichting en Landelijk Centrum GVO.

Wiedenhof, N. (1988). Industrievoorlichting: Een inleiding. Muiderberg: Coultinho.

Wiegman, O., Roon, A.D. de, en Snijders, Th.(1981). Meningen en media: Politieke opponenten in eet realistisch experiment. Deventer: Van Loghum Slaterus.

Wilde, G.J.S. (1982). The theory of risk homeostasis. Risk Analysis, 2, 209-225.

Wilke, H.A.M. (1980). Informatieverwerking en sociale vergelijking. In J.B. Rijsman, en H.A.M. Wilke (Red.), Sociale vergelijkingsprocessen, theorie en onderzoek ( $\mathrm{pp} .34$-62). Deventer: Van Loghum Slaterus.

Willenborg, G.B.W., en Schmidt, T. (1989). De campagne "De auto met katalysator, de juiste keus ": Een evaluatieonderzoek naar het voorlichtingsproces en de effecten wan een postbus 51-campagne (Onderzoeksrapport 78). Den Haag: Swoka.

Williams, F. (1989). De Nieuwe media: Enkele conceptuele parameters. In Bouwman, en Jankowski (Red.), Interactieve media op komst (pp.28-38). Amsterdam: Otto Cramwinckel.

Williams, F., Rice, R.E., en Rogers, E. (1988). Research methods and the New Media. New York: The Free Press.

Winkel, F.W. (1987). Politie en voorkoming misdrijoen: Effecten en neveneffecten van voorlichting. Proefschrift.

Winsemius, P. (1985). Communicatie en overheidsbeleid. In J. Katus, en H.C. Beets (Red.), Actuele vraggstukken van de overheidswoorlichting (pp. 71-84). Muiderberg: Coutinho.

Woerkum, C.M.J van (1982). Voorlichtingskunde en massacommunicatie. Proefschrift. Wageningen: Landbouwhogeschool Wageningen. 
Woerkum, C.M.J. van (1987). Voorlichtingskunde: Diaspora of driestromenland. Massacommunicatie, 15, 331-343.

Woerkum, C.M.J. van (1989). De samenhang tussen het massamediale aanbod en de ontwikkeling van de vraag naar voorlichting. In Bosman, J. (Red.), Het angaan met kentris en de vraag naar voorlichting: Een multidisciplinair theoretisch referentiekader voor empirisch onderzoek near de orang naar voorlichting (pp. 95-115). Nijmegen: Instituut voor Toegepaste Sociale Wetenschappen.

Woerkum, C.M.J. van (1990). Voorlichting als beleidsinstrument: Niettw en krachtig? Inaugurele rede. Landbouwuniversiteit Wageningen.

Woerkum, C.M.J. van, Doorn, N. van, en Loeve, B. (1987). Voorlichten met drukwerk. Muiderberg: Coutinho.

Wortman, C.B., en Brehm, J.W. (1975). Responses to uncontrollable outcomes: An integration of reactance theorie and the learned helplessness model. In L. Berkowitz (Ed.), Adtances in experimental sacial psychology (Vol. 18, pp. 278-236). New York: Academic Press.

Wright, W.R. (1975). Mass media as sources of medical information. Journal of Communication, Media and Medicine, 197-209.

Young, L.R. (1976). The etiology of ski injuries: An eight year study of the skier and his equipment. Orthopedic Clin. North. Am., 7, 13-29.

Zaltman, G., en Duncan, R. (1977). Strategies for planned change. New York: Wiley.

Zanna, M.P., Olson, J.M., en Fazjo, R.H. (1980). Attitude-behavior consistency an individual difference perspective. Journal of Persotiality and Social Psychalogy, 38, 432-440.

Zuckerman, M. (1984). Sensation seeking: A comparative approach to a human trait. The Behavioral and Brain Sciences, 7, 413-471. 


\section{Curriculum vitae}

Victor Damoiseaux werd op 24 april 1949 geboren te Amby. Hij studeerde sociologie en publicistiek aan de Katholieke Universiteit te Nijmegen en politicologie met als specialisatie massacommunicatie aan de Gemeentelijke Universiteit van Amsterdam. Hij is gedurende 5 jaar werkzaam geweest als GVO-consulent in Noord-Oost Noord Brabant. Sinds 1980 is hij verbonden als universitair docent aan de vakgroep Gezondheidsvoorlichting en -opvoeding van de Rijksuniversiteit Limburg met als aandachtsgebieden patiëntenvoorlichting en massacommunicatie. Van zijn hand verschenen diverse publicaties over deze thema's. Hij was hoofdredacteur van het tijdschrift GVO/Preventie. Hij is eindredacteur van een aantal handboeken op het gebied van gezondheidsvoorlichting en doceert post-academisch onderwijs op dit terrein. Hij heeft zitting in diverse nationale begeleidingscommissies en werkgroepen en adviseert gezondheidszorginstellingen en voorlichtingsorganisaties. 